\title{
Pyrimidazole-Based Covalent Organic Frameworks: Integrating Functionality and Ultrastability via Isocyanide Chemistry
}

Jiao Liu, Tong Yang, Zhi-Peng Wang, Peng-Lai Wang, Jie Feng, San-Yuan Ding, ${ }^{*}$ Wei Wang*

State Key Laboratory of Applied Organic Chemistry, College of Chemistry and Chemical Engineering, Lanzhou University, Lanzhou, Gansu 730000 , China

`E-mail: dingsy@|zu.edu.cn; wang_wei@|zu.edu.cn
A. Summary of Figures and Tables
B. General Information
C. Synthesis of Monomers and Model Compound
D. Synthesis and Characterization of LZU-561
E. Synthesis and Characterization of LZU-562
F. Synthesis and Characterization of LZU-563
S29
G. Synthesis and Characterization of LZU-564
H. Synthesis and Characterization of LZU-565
I. Synthesis and Characterization of LZU-566
J. Synthesis and Characterization of LZU-567
K. Synthesis and Characterization of LZU-568
L. Stability Tests
M. UV/Vis Absorption Spectra
N. References
O. Liquid ${ }^{1} \mathrm{H}$ and ${ }^{13} \mathrm{C}$ NMR Spectra 


\section{A. Summary of Figures and Tables}

Fig. S1 FT-IR spectrum of model compound M1

Fig. S2 PXRD patterns of LZU-561 synthesized in different solvents

Fig. S3 PXRD patterns of LZU-561 synthesized with indicated conditions

Fig. S4 $\quad \mathrm{N}_{2}$ adsorption and desorption isotherms of LZU-561

Fig. S5 Pore size distribution of LZU-561

Fig. S6 BET surface area plot for LZU-561

Fig. S7 FT-IR spectra of monomers, catalyst and LZU-561

Fig. S8 $\quad{ }^{13} \mathrm{C}$ CP/MAS spectrum of LZU-561

Fig. S9 $\quad{ }^{13} \mathrm{C} \mathrm{CP/MAS} \mathrm{spectrum} \mathrm{of}{ }^{13} \mathrm{C}$-labeled LZU-561

Fig. S10 TGA data of LZU-561

Fig. S11 SEM and TEM images of LZU-561 S16

Fig. S12 Indexed PXRD pattern and Pawley-refined profile of LZU-561 $\quad$ S17

$\begin{array}{lll}\text { Fig. S13 Observed and calculated PXRD patterns of LZU-561 } & \text { S18 }\end{array}$

$\begin{array}{lll}\text { Fig. S14 PXRD patterns of monomers, catalyst and LZU-561 } & \text { S18 }\end{array}$

Tab. S1 Fractional atomic coordinates for the unit cell of LZU-561

Fig. S15 PXRD pattern of LZU-562

$\begin{array}{lll}\text { Fig. S16 } & \mathrm{N}_{2} \text { adsorption and desorption isotherms of LZU-562 } & \text { S21 }\end{array}$

$\begin{array}{lll}\text { Fig. S17 Pore size distribution of LZU-562 } & \text { S22 }\end{array}$

$\begin{array}{lll}\text { Fig. S18 BET surface area plot for LZU-562 } & \text { S22 }\end{array}$

$\begin{array}{lll}\text { Fig. S19 FT-IR spectra of monomers, catalyst and LZU-562 S23 } & \text { S62 }\end{array}$

$\begin{array}{lll}\text { Fig. S20 } & { }^{13} \mathrm{C} \text { CP/MAS spectrum of LZU-562 S23 }\end{array}$

$\begin{array}{lll}\text { Fig. S21 } & { }^{13} \mathrm{C} \text { CP/MAS spectrum of }{ }^{13} \mathrm{C} \text {-labeled LZU-562 } & \text { S24 }\end{array}$

$\begin{array}{lll}\text { Fig. S22 TGA data of LZU-562 } & \text { S24 }\end{array}$

$\begin{array}{lll}\text { Fig. S23 SEM images of LZU-562 } & \text { S25 }\end{array}$

Fig. S24 TEM images of LZU-562 $\quad$ S25

Fig. S25 Indexed PXRD pattern and Pawley-refined profile of LZU-562 S26

$\begin{array}{lll}\text { Fig. S26 Observed and calculated PXRD patterns of LZU-562 } & \text { S27 }\end{array}$

$\begin{array}{lll}\text { Fig. S27 PXRD patterns of monomers, catalyst and LZU-562 } & \text { S27 }\end{array}$

Tab. S2 Fractional atomic coordinates for the unit cell of LZU-562 S28

$\begin{array}{llr}\text { Fig. S28 PXRD pattern of LZU-563 } & \text { S30 }\end{array}$

$\begin{array}{lll}\text { Fig. S29 } & \mathrm{N}_{2} \text { adsorption and desorption isotherms of LZU-563 } & \text { S30 }\end{array}$

$\begin{array}{lll}\text { Fig. S30 Pore size distribution of LZU-563 S31 } & \text { P3 }\end{array}$ 
$\begin{array}{lll}\text { Fig. S31 BET surface area plot for LZU-563 } & \text { S31 }\end{array}$

$\begin{array}{lll}\text { Fig. S32 } & \text { FT-IR spectra of monomers, catalyst and LZU-563 S32 }\end{array}$

$\begin{array}{lll}\text { Fig. S33 } & { }^{13} \mathrm{C} \text { CP/MAS spectrum of LZU-563 S32 }\end{array}$

Fig. S34 ${ }^{13} \mathrm{C}$ CP/MAS spectrum of ${ }^{13}$ C-labeled LZU-563 S33

$\begin{array}{lll}\text { Fig. S35 TGA data of LZU-563 } & \text { S33 }\end{array}$

$\begin{array}{lll}\text { Fig. S36 SEM images of LZU-563 S34 } & \end{array}$

$\begin{array}{lll}\text { Fig. S37 TEM images of LZU-563 S34 } & \end{array}$

Fig. S38 Indexed PXRD pattern and Pawley-refined profile of LZU-563 S35

Fig. S39 Observed and calculated PXRD patterns of LZU-563 S36

Fig. S40 PXRD patterns of monomers, catalyst and LZU-563 S36

Tab. S3 Fractional atomic coordinates for the unit cell of LZU-563 S37

$\begin{array}{llr}\text { Fig. S41 PXRD pattern of LZU-564 } & \text { S39 }\end{array}$

$\begin{array}{lll}\text { Fig. S42 } & \mathrm{N}_{2} \text { adsorption and desorption isotherms of LZU-564 } & \text { S39 }\end{array}$

$\begin{array}{lll}\text { Fig. S43 Pore size distribution of LZU-564 S40 } & \text { S4 }\end{array}$

$\begin{array}{lll}\text { Fig. S44 BET surface area plot for LZU-564 } & \text { S40 }\end{array}$

Fig. S45 FT-IR spectra of monomers, catalyst and LZU-564 S41

$\begin{array}{lll}\text { Fig. S46 } & { }^{13} \mathrm{C} \text { CP/MAS spectrum of LZU-564 S41 }\end{array}$

Fig. S47 $\quad{ }^{13} \mathrm{C}$ CP/MAS spectrum of ${ }^{13} \mathrm{C}$-labeled LZU-564 S42

$\begin{array}{llr}\text { Fig. S48 TGA data of LZU-564 } & \text { S42 }\end{array}$

$\begin{array}{lll}\text { Fig. S49 SEM images of LZU-564 S43 } & \text { S4 }\end{array}$

$\begin{array}{lll}\text { Fig. S50 TEM images of LZU-564 S43 } & \text { T2 }\end{array}$

Fig. S51 Indexed PXRD pattern and Pawley-refined profile of LZU-564 $\quad$ S44

Fig. S52 Observed and calculated PXRD patterns of LZU-564 S45

Fig. S53 PXRD patterns of monomers, catalyst and LZU-564 S45

Tab. S4 Fractional atomic coordinates for the unit cell of LZU-564 S46

$\begin{array}{llr}\text { Fig. S54 PXRD pattern of LZU-565 } & \text { S48 }\end{array}$

$\begin{array}{lll}\text { Fig. S55 } & \mathrm{N}_{2} \text { adsorption and desorption isotherms of LZU-565 } & \text { S48 }\end{array}$

$\begin{array}{llr}\text { Fig. S56 Pore size distribution of LZU-565 } & \text { S49 }\end{array}$

$\begin{array}{lll}\text { Fig. S57 } & \text { BET surface area plot for LZU-565 } & \text { S49 }\end{array}$

$\begin{array}{llr}\text { Fig. S58 } & \text { FT-IR spectra of monomers, catalyst and LZU-565 }\end{array}$

Fig. S59 ${ }^{13} \mathrm{C} \mathrm{CP/MAS} \mathrm{spectrum} \mathrm{of} \mathrm{LZU-565}$

Fig. S60 ${ }^{13} \mathrm{C}$ CP/MAS spectrum of ${ }^{13} \mathrm{C}$-labeled LZU-565

$\begin{array}{lll}\text { Fig. S61 TGA data of LZU-565 } & \text { S51 }\end{array}$

Fig. S62 SEM images of LZU-565

Fig. S63 TEM images of LZU-565 
Fig. S64 Indexed PXRD pattern and Pawley-refined profile of LZU-565

Fig. S65 Observed and calculated PXRD patterns of LZU-565 S54

Fig. S66 PXRD patterns of monomers, catalyst and LZU-565

Tab. S5 Fractional atomic coordinates for the unit cell of LZU-565

$\begin{array}{lll}\text { Fig. S67 } & \text { PXRD pattern of LZU-566 }\end{array}$

$\begin{array}{lll}\text { Fig. S68 } & \mathrm{N}_{2} \text { adsorption and desorption isotherms of LZU-566 } & \text { S57 }\end{array}$

$\begin{array}{llr}\text { Fig. S69 Pore size distribution of LZU-566 } & \text { S58 }\end{array}$

$\begin{array}{lll}\text { Fig. S70 BET surface area plot for LZU-566 } & \text { S58 }\end{array}$

Fig. S71 FT-IR spectra of monomers, catalyst and LZU-566 $\quad$ S59

$\begin{array}{llr}\text { Fig. S72 } & { }^{13} \mathrm{C} \text { CP/MAS spectrum of LZU-566 } & \text { S59 }\end{array}$

Fig. S73 ${ }^{13} \mathrm{C}$ CP/MAS spectrum of ${ }^{13} \mathrm{C}$-labeled LZU-566 $\quad$ S60

Fig. S74 TGA data of LZU-566 $\quad$ S60

$\begin{array}{lll}\text { Fig. S75 SEM images of LZU-566 } & \text { S61 }\end{array}$

Fig. S76 TEM images of LZU-566 S61

Fig. S77 Indexed PXRD pattern and Pawley-refined profile of LZU-566 $\quad$ S62

Fig. S78 Observed and calculated PXRD patterns of LZU-566 S63

Fig. S79 PXRD patterns of monomers, catalyst and LZU-566 S63

Tab. S6 Fractional atomic coordinates for the unit cell of LZU-566 S64

$\begin{array}{llr}\text { Fig. S80 PXRD pattern of LZU-567 } & \text { S66 }\end{array}$

$\begin{array}{lll}\text { Fig. S81 } & \mathrm{N}_{2} \text { adsorption and desorption isotherms of LZU-567 } & \text { S66 }\end{array}$

$\begin{array}{lll}\text { Fig. S82 Pore size distribution of LZU-567 } & \text { S67 }\end{array}$

$\begin{array}{lll}\text { Fig. S83 } & \text { BET surface area plot for LZU-567 } & \text { S67 }\end{array}$

Fig. S84 FT-IR spectra of monomers, catalyst and LZU-567 S68

$\begin{array}{lll}\text { Fig. S85 } & { }^{13} \mathrm{C} \text { CP/MAS spectrum of LZU-567 } & \text { S68 }\end{array}$

$\begin{array}{llr}\text { Fig. S86 } & { }^{13} \mathrm{C} \text { CP/MAS spectrum of }{ }^{13} \mathrm{C} \text {-labeled LZU-567 } & \text { S69 }\end{array}$

$\begin{array}{lll}\text { Fig. S87 TGA data of LZU-567 } & \text { S69 }\end{array}$

$\begin{array}{lll}\text { Fig. S88 SEM images of LZU-567 } & \text { S70 }\end{array}$

$\begin{array}{lll}\text { Fig. S89 TEM images of LZU-567 } & \text { S70 }\end{array}$

Fig. S90 Indexed PXRD pattern and Pawley-refined profile of LZU-567 S71

$\begin{array}{lll}\text { Fig. S91 Observed and calculated PXRD patterns of LZU-567 } & \text { S72 }\end{array}$

$\begin{array}{lll}\text { Fig. S92 PXRD patterns of monomers, catalyst and LZU-567 } & \text { S72 }\end{array}$

Tab. S7 Fractional atomic coordinates for the unit cell of LZU-567

$\begin{array}{lll}\text { Fig. S93 PXRD pattern of LZU-568 } & \text { S75 }\end{array}$

$\begin{array}{lll}\text { Fig. S94 } & \mathrm{N}_{2} \text { adsorption and desorption isotherms of LZU-568 } & \text { S75 }\end{array}$ 
Fig. S95 Pore size distribution of LZU-568 $\quad$ S76

$\begin{array}{lll}\text { Fig. S96 BET surface area plot for LZU-568 } & \text { S76 }\end{array}$

$\begin{array}{lll}\text { Fig. S97 } & \text { FT-IR spectra of monomers, catalyst and LZU-568 } & \text { S77 }\end{array}$

$\begin{array}{lll}\text { Fig. S98 } & { }^{13} \mathrm{C} \text { CP/MAS spectrum of LZU-568 } & \text { S77 }\end{array}$

$\begin{array}{lll}\text { Fig. S99 } & { }^{13} \mathrm{C} \text { CP/MAS spectrum of }{ }^{13} \mathrm{C} \text {-labeled LZU-568 } & \text { S78 }\end{array}$

$\begin{array}{lll}\text { Fig. S100 TGA data of LZU-568 } & \text { S78 }\end{array}$

$\begin{array}{llr}\text { Fig. S101 SEM images of LZU-568 } & \text { S79 }\end{array}$

$\begin{array}{llr}\text { Fig. S102 TEM images of LZU-568 } & \text { S79 }\end{array}$

Fig. S103 Indexed PXRD pattern and Pawley-refined profile of LZU-568 $\quad$ S80

Fig. S104 Observed and calculated PXRD patterns of LZU-568 S81

Fig. S105 PXRD patterns of monomers, catalyst and LZU-568 S81

Tab. S8 Fractional atomic coordinates for the unit cell of LZU-568

Fig. S106 Residue weight percentage of LZU-563 after treatment S83

$\begin{array}{lll}\text { Fig. S107 SEM images of LZU-563 before and after treatment } & \text { S84 }\end{array}$

Fig. S108 ${ }^{13} \mathrm{C}$ CP/MAS NMR spectra of LZU-563 before and after treatment $\quad$ S85

Fig. S109 Isotherms of LZU-563 after treatment with water S86

Fig. S110 BET surface area plot for LZU-563 after treatment with water $\quad$ S86

$\begin{array}{lll}\text { Fig. S111 } & \mathrm{N}_{2} \text { isotherms of LZU-563 after treatment with DMF } & \text { S87 }\end{array}$

$\begin{array}{lll}\text { Fig. S112 BET surface area plot for LZU-563 after treatment with DMF } & \text { S87 }\end{array}$

Fig. S113 $\mathrm{N}_{2}$ isotherms of LZU-563 after treatment with 9 $\mathrm{M} \mathrm{HCl} \quad \mathrm{S} 88$

Fig. S114 BET surface area plot for LZU-563 after treatment with $9 \mathrm{M} \mathrm{HCl} \quad$ S88

Fig. S115 $\mathrm{N}_{2}$ isotherms of LZU-563 after treatment with $9 \mathrm{M} \mathrm{NaOH} \quad$ S89

Fig. S116 BET surface area plot for LZU-563 after treatment with $9 \mathrm{M} \mathrm{NaOH} \quad$ S89

Fig. S117 PXRD patterns of LZU-563 before and after treatment with boiling water $\quad$ S90

Fig. S118 PXRD patterns of LZU-563 before and after heating S90

Fig. S119 UV/vis absorption spectra of LZU-561, LZU-562, LZU-563, and LZU-564 S91

Fig. S120 UV/vis absorption spectra of LZU-565, LZU-566, LZU-567, and LZU-568 S91

Fig. S121 $(\alpha h v)^{2}$ versus hv curve of of LZU-565, LZU-566, LZU-567, and LZU-568 S92 


\section{B. General Information}

All reagents and solvents were obtained from commercial sources and used as received. Ethanol $(\mathrm{EtOH})$ and $N, N$-dimethylformamide (DMF) was obtained from RionlonBohua (Tianjin) Pharmaceutical \& Chemical. ${ }^{13} \mathrm{C}$-labeled formic acid $(98 \%$

${ }^{13} \mathrm{C}$ enrichment) was obtained from Sigma-Aldrich. 1,2-Dichlorobenzene (o-DCB) and $n$-butanol $(n-\mathrm{BuOH})$ were obtained from Alfa Aesar. Mesitylene was obtained from Acros Organics. 1,3,5-Tris(3-fluoro-4-formyl phenyl)benzene was obtained from Jilin Chinese Academy of Sciences Yanshen Technology Co., Ltd. 2-Aminopyridine, 2-amino-4-chloropyridine, and 2-amino-5-bromo-4-methylpyridine were purchased from Aladdin. 2-Amino-5-methoxypyridine was purchased from Energy Chemical Reagent. 1,4-Phenylenediamine was purchased from Innochem. 1,3,5-Tris(4-amino phenyl)- benzene was purchased from Zhengzhou Alfachem.

FT-IR spectra were recorded on a Nicolet NEXUS 670 instrument. Powder X-ray diffraction (PXRD) data were collected on a PANalytical X'Pert Pro diffractometer operated at $40 \mathrm{kV}$ and $40 \mathrm{~mA}$ with $\mathrm{Cu} \mathrm{K} \alpha$ radiation (step size of $0.017^{\circ}$ and step time of $8.41 \mathrm{~s})$. Elemental analysis was performed on an Elementar Analysensysteme GmbH VarioEL V3.00 elemental analyzer. Solid-state NMR experiments were performed on a Bruker WB Avance II $400 \mathrm{MHz}$ spectrometer. Solid-state ${ }^{13} \mathrm{C}$ cross-polarization magic-angle spinning $\left({ }^{13} \mathrm{C} \mathrm{CP} / \mathrm{MAS} \mathrm{NMR}\right)$ spectra were recorded with a 4-mm double-resonance MAS probe; a sample spinning rate of $10.0 \mathrm{kHz}$, a contact time of $3 \mathrm{~ms}$ (ramp 100), and a pulse delay of $3 \mathrm{~s}$ were applied. Field emission scanning electron microscopy (SEM) observations were performed on a Hitachi S-4800 microscope operated at an accelerating voltage of $5.0 \mathrm{kV}$. Transmission electron microscopy (TEM) images were obtained with an FEI TF20 instrument operated at $200 \mathrm{kV}$. The thermal properties of COF samples were evaluated with a STA PT1600 Linseis thermogravimetric analysis (TGA) instrument over the temperature range of 50 to $700{ }^{\circ} \mathrm{C}$ under nitrogen atmosphere with a heating rate of $10{ }^{\circ} \mathrm{C} / \mathrm{min}$. Nitrogen adsorption and desorption isotherms were recorded at $77 \mathrm{~K}$ with a Micromeritics ASAP 2020M system. Prior to the measurement of the sorption isotherm, the samples were outgased for $8 \mathrm{~h}$ at $120^{\circ} \mathrm{C}$. Surface areas were calculated using the Brunauer-Emmett-Teller (BET) method. The pore-size-distribution curves were obtained via the non-local density functional theory (NLDFT). 


\section{Synthesis of Monomers and Model Compound}

Synthesis of 1,3,5-tris(4-isocyanophenyl)benzene ${ }^{1}$

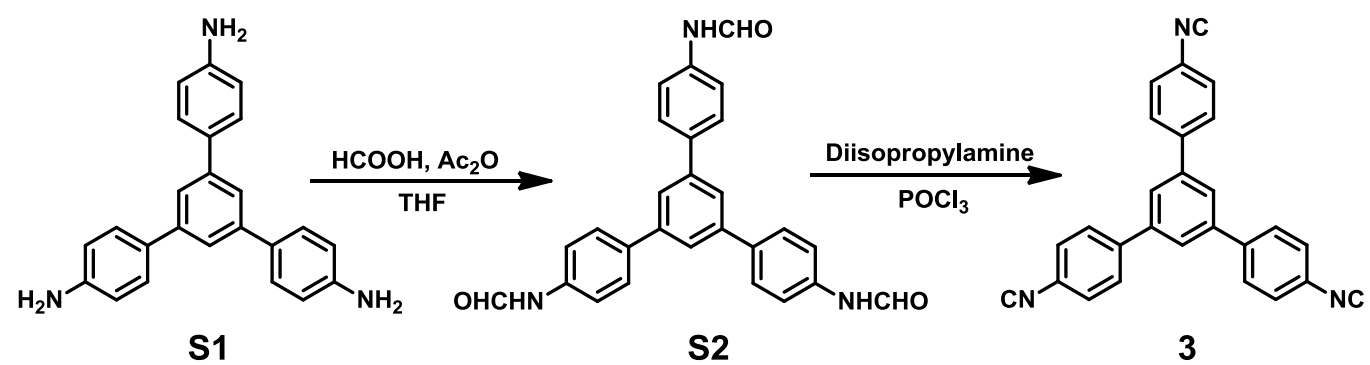

A mixture of formic acid $(6.8 \mathrm{~mL}, 0.18 \mathrm{~mol})$ and acetic anhydride $(12.4 \mathrm{~mL}, 0.13$ mol) was heated at $70{ }^{\circ} \mathrm{C}$ for $2 \mathrm{~h}$, then cooled to $0{ }^{\circ} \mathrm{C}$. A solution of 1,3,5-tris(4-aminophenyl)benzene $\mathbf{S 1}(2.0 \mathrm{~g}, 5.69 \mathrm{mmol})$ in THF $(25 \mathrm{~mL})$ was added dropwise to the above solution over a period of $0.5 \mathrm{~h}$ at $0{ }^{\circ} \mathrm{C}$ with stirring. After being stirred at $0{ }^{\circ} \mathrm{C}$ for $8 \mathrm{~h}$, the mixture was evaporated to give the crude $\mathbf{S 2}$. To a flask with S2 was added diisopropylamine $(12.0 \mathrm{~mL}, 85.60 \mathrm{mmol})$ and dichloromethane $(60 \mathrm{~mL})$. The resulting suspension of $\mathbf{S 2}$ was cooled to $0{ }^{\circ} \mathrm{C}$ and phosphorous oxychloride $\left(\mathrm{POCl}_{3}, 2.2 \mathrm{~mL}, 23.60 \mathrm{mmol}\right)$ was added dropwise over 20 minutes. After the addition of the $\mathrm{POCl}_{3}$, the mixture was stirred for $1 \mathrm{~h}$ at $0{ }^{\circ} \mathrm{C}$ and $2 \mathrm{~h}$ at room temperature. The reaction mixture was cooled to $0{ }^{\circ} \mathrm{C}$, and saturated sodium bicarbonate solution was added. The final two-phase mixture was stirred for $0.5 \mathrm{~h}$. The organic phase was separated and the aqueous phase was extracted with dichloromethane $(3 \times 20 \mathrm{~mL})$. The combined organic phases were washed with brine $(2 \times 30 \mathrm{~mL})$, dried over anhydrous $\mathrm{Na}_{2} \mathrm{SO}_{4}$, and evaporated in vacuo to give the crude product, which was purified by flash chromatography $\left(\mathrm{CH}_{2} \mathrm{Cl}_{2} / \mathrm{PE}: 2 / 1\right)$ to afford monomer 3 as a white solid (1.45 g, 67\%). ${ }^{1} \mathrm{H}$ NMR (400 MHz, $\left.\mathrm{CDCl}_{3}\right) \delta=7.70(\mathrm{~d}, J$ $=8.4 \mathrm{~Hz}, 6 \mathrm{H}), 7.51(\mathrm{~d}, J=8.4 \mathrm{~Hz}, 6 \mathrm{H}), 7.73(\mathrm{~s}, 3 \mathrm{H}) .{ }^{13} \mathrm{C} \mathrm{NMR}\left(100 \mathrm{MHz}, \mathrm{CDCl}_{3}\right) \delta$ $=165.3,141.5,141.2,128.3,127.0,126.2,125.8$. HRMS: $\mathrm{m} / \mathrm{z}$ calcd for $\mathrm{C}_{27} \mathrm{H}_{15} \mathrm{~N}_{3}[\mathrm{M}$ $+\mathrm{H}]^{+}:$382.1339, found: 382.1332 .

The synthesis of ${ }^{13} \mathrm{C}$-labeled $1,3,5$-tris(4-isocyanophenyl)benzene $\left(-\mathrm{N} \equiv{ }^{13} \mathrm{C}\right)$ by using the ${ }^{13} \mathrm{C}$-labeled formic acid was similar to that of compound $\mathbf{3}$. 
Synthesis of 1,4-diisocyanobenzene ${ }^{1}$

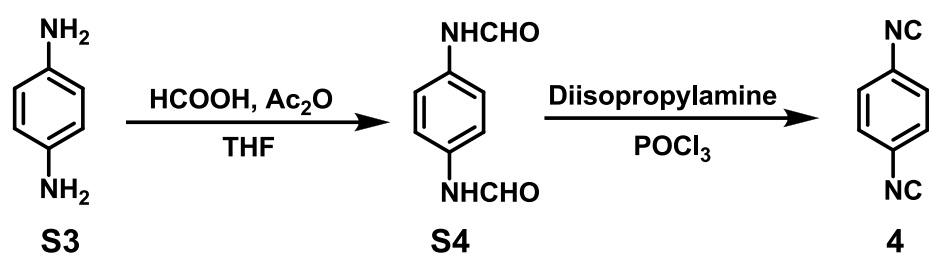

The synthetic procedure of 1,4-diisocyanobenzene was similar to that of compound 3. A mixture of formic acid $(4.5 \mathrm{~mL}, 0.12 \mathrm{~mol})$ and acetic anhydride $(9.5$ $\mathrm{mL}, 0.10 \mathrm{~mol}$ ) was heated at $70{ }^{\circ} \mathrm{C}$ for $2 \mathrm{~h}$, then cooled to $0{ }^{\circ} \mathrm{C}$. A solution of 1,4-phenylenediamine $\mathbf{S 3}(2.0 \mathrm{~g}, 18.51 \mathrm{mmol})$ in THF $(25.0 \mathrm{~mL})$ was added dropwise to the above solution over a period of $0.5 \mathrm{~h}$ at $0{ }^{\circ} \mathrm{C}$ with stirring. After being stirred at $0{ }^{\circ} \mathrm{C}$ for $8 \mathrm{~h}$, the mixture was evaporated to give the crude $\mathbf{S 4}$. To a flask with $\mathbf{S 4}$ was added diisopropylamine $(21.0 \mathrm{~mL}, 148.00 \mathrm{mmol})$ and dichloromethane. The resulting suspension of $\mathbf{S 4}$ was cooled to $0{ }^{\circ} \mathrm{C}$ and phosphorous oxychloride (4.0 mL, 44.40 mmol) was added dropwise over 20 minutes. After the addition of the $\mathrm{POCl}_{3}$, the mixture was stirred for $1 \mathrm{~h}$ at $0{ }^{\circ} \mathrm{C}$ and $2 \mathrm{~h}$ at room temperature. The reaction mixture was cooled to $0{ }^{\circ} \mathrm{C}$, and saturated sodium bicarbonate solution was added. The final two-phase mixture was stirred for $0.5 \mathrm{~h}$. The organic phase was separated and the aqueous phase was extracted with dichloromethane $(3 \times 20 \mathrm{~mL})$. The combined organic phases were washed with brine $(2 \times 30 \mathrm{~mL})$, dried over anhydrous $\mathrm{Na}_{2} \mathrm{SO}_{4}$, and evaporated in vacuo to give the crude product, which was purified by flash chromatography $\left(\mathrm{CH}_{2} \mathrm{Cl}_{2} / \mathrm{PE}: 2: 1\right)$ to afford monomer 4 as a white solid $(1.80 \mathrm{~g}$, 76\%). ${ }^{1} \mathrm{H}$ NMR $\left(400 \mathrm{MHz}, \mathrm{CDCl}_{3}\right) \delta=7.73(\mathrm{~s}, 4 \mathrm{H}) .{ }^{13} \mathrm{C} \mathrm{NMR}\left(100 \mathrm{MHz}, \mathrm{CDCl}_{3}\right) \delta=$ 163.9, 124.1, 123.3. HRMS: $\mathrm{m} / \mathrm{z}$ calcd for $\mathrm{C}_{8} \mathrm{H}_{4} \mathrm{~N}_{2}[\mathrm{M}+\mathrm{H}]^{+}:$129.0447, found: 129.0449 .

The synthesis of ${ }^{13} \mathrm{C}$-labeled 1,4 -diisocyanobenzene $\left(-\mathrm{N} \equiv{ }^{13} \mathrm{C}\right)$ by using the ${ }^{13} \mathrm{C}$-labeled formic acid was similar to that of compound 4. 


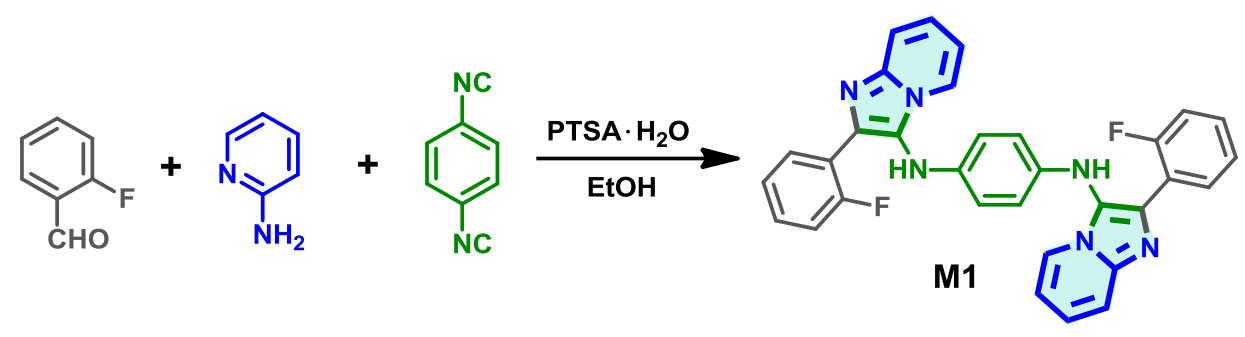

2-Fluorobenzaldehyde (59 $\mu \mathrm{L}, 0.56 \mathrm{mmol})$, 2-aminopyridine (58 $\mathrm{mg}, 0.62 \mathrm{mmol}$ ), 1,4-diisocyanobenzene (36 mg, $0.28 \mathrm{mmol}$ ), and p-toluenesulfonic acid monohydrate (21 mg, $0.11 \mathrm{mmol}$ ) were weighed into a glass tube (volume of $c a .10 \mathrm{~mL}$, body length of $18 \mathrm{~cm}$, and neck length of $9 \mathrm{~cm})$. To the mixture was added ethanol $(2 \mathrm{~mL})$. The tube was flash frozen in a liquid nitrogen bath, evacuated to an internal pressure of 0.5 mbar and flame sealed, reducing the total length by $c a .10 \mathrm{~cm}$. Upon warming to room temperature, the sealed tube was placed in an oven at $120{ }^{\circ} \mathrm{C}$ and left undisturbed for 3 days, yielding M1 (142 mg, 96\%). ${ }^{1} \mathrm{H}$ NMR (400 MHz, DMSO) $\delta=$ $7.84(\mathrm{~d}, J=6.8 \mathrm{~Hz}, 2 \mathrm{H}), 7.71-7.67(\mathrm{~m}, 2 \mathrm{H}), 7.61-7.58(\mathrm{~m}, 4 \mathrm{H}), 7.40-7.35(\mathrm{~m}, 2 \mathrm{H})$, 7.29-7.20 (m, 6H), $6.91(\mathrm{t}, J=6.7 \mathrm{~Hz}, 2 \mathrm{H}), 6.26(\mathrm{~s}, 4 \mathrm{H}) .{ }^{13} \mathrm{C} \mathrm{NMR}(100 \mathrm{MHz}, \mathrm{DMSO})$ $\delta=159.9(\mathrm{~d}, J=247.9 \mathrm{~Hz}), 142.0,138.3,133.8,131.6(\mathrm{~d}, J=3.6 \mathrm{~Hz}), 130.0(\mathrm{~d}, J=$ $8.0 \mathrm{~Hz}), 125.0,124.6(\mathrm{~d}, J=3.3 \mathrm{~Hz}), 123.8,122.5(\mathrm{~d}, J=13.9 \mathrm{~Hz}), 122.1,117.7$, $116.4(\mathrm{~d}, J=21.7 \mathrm{~Hz}), 114.8,112.5$. HRMS: $\mathrm{m} / \mathrm{z}$ calcd for $\mathrm{C}_{32} \mathrm{H}_{22} \mathrm{~F}_{2} \mathrm{~N}_{6}[\mathrm{M}+\mathrm{H}]^{+}$: 529.1942, found: 529.1947. 


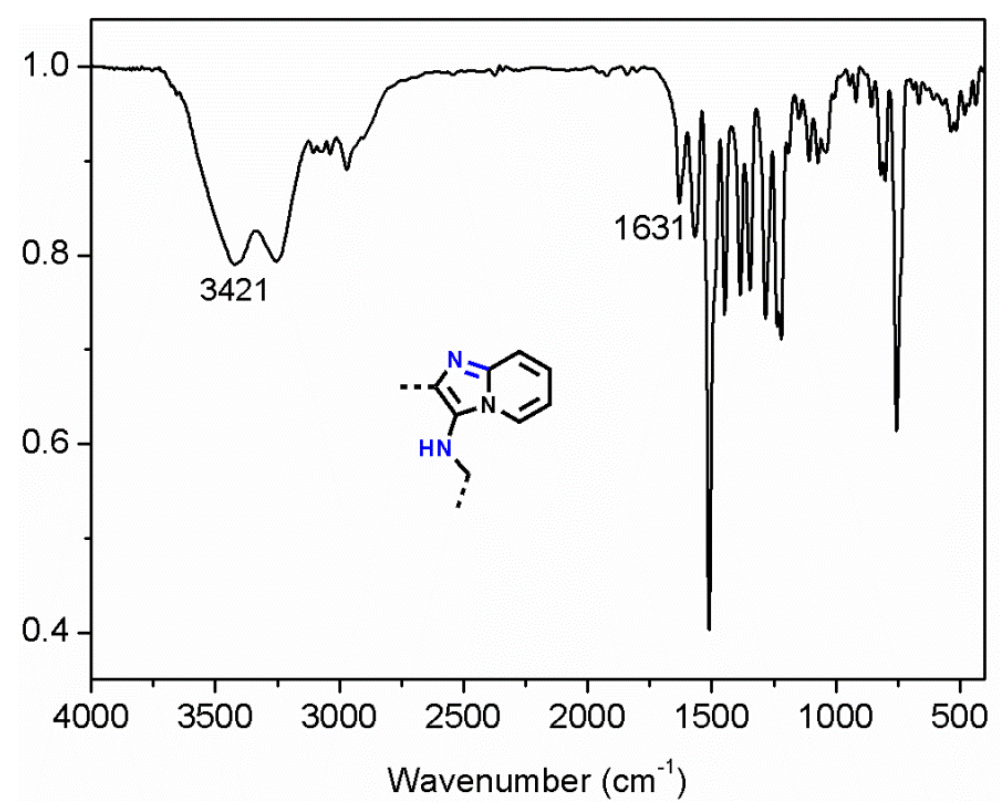

Figure S1. FT-IR spectrum of the model compound M1. The bands at $1631(v-\mathrm{N}=\mathrm{C}-)$ and $3421 \mathrm{~cm}^{-1}$ are characteristic for the pyrimidazole ring and $\mathrm{N}-\mathrm{H}$ bands, respectively. $^{2}$ 


\section{Synthesis and Characterization of LZU-561}

Synthesis of LZU-561

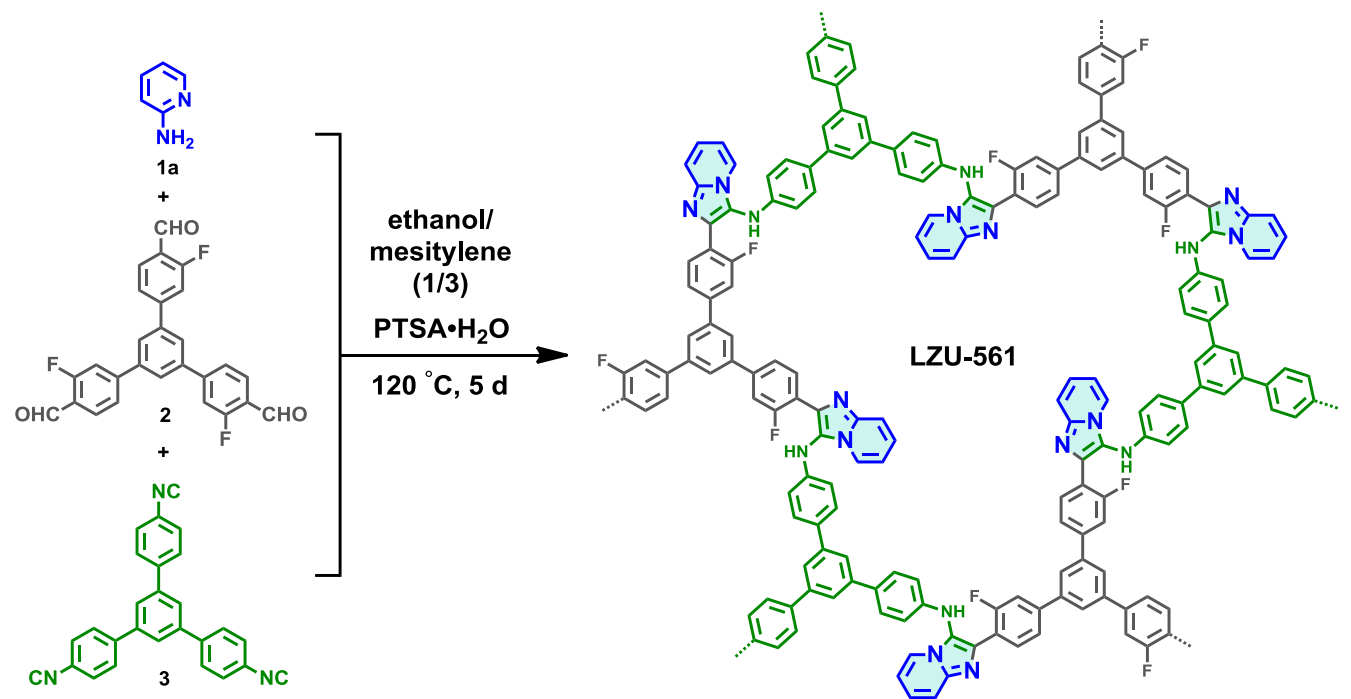

2-Amino-pyridine 1a (17.0 mg, $0.180 \mathrm{mmol})$, 1,3,5-tris(3-fluoro-4-formyl phenyl)benzene 2 (22.3 $\mathrm{mg}, 0.050 \mathrm{mmol})$, 1,3,5-tris(4-isocyanophenyl) benzene 3 (17.6 mg, $0.046 \mathrm{mmol})$, and $p$-toluenesulfonic acid monohydrate $(7.0 \mathrm{mg}, 0.037 \mathrm{mmol})$ were weighed into a glass tube (volume of $c a .10 \mathrm{~mL}$, body length of $18 \mathrm{~cm}$, and neck length of $9 \mathrm{~cm})$. To the mixture was added ethanol $(0.10 \mathrm{~mL})$ and mesitylene $(0.30$ $\mathrm{mL})$. The tube was flash frozen in a liquid nitrogen bath, evacuated to an internal pressure of 0.5 mbar and flame sealed, reducing the total length by $c a .10 \mathrm{~cm}$. Upon warming to room temperature, the sealed tube was placed in an oven at $120{ }^{\circ} \mathrm{C}$ and left undisturbed for 5 days, yielding a pale brown solid. The tube was broken at the neck, and the pale brown solid was isolated and purified by using Soxhlet extraction with $\mathrm{EtOH}$ as the solvent for 1 day. The powder was collected and dried at $80{ }^{\circ} \mathrm{C}$ for $12 \mathrm{~h}$ to yield LZU-561 as a pale brown powder (36.8 mg, $76 \%$ yield). Anal. Cald for $\left(\mathrm{C}_{23} \mathrm{H}_{14} \mathrm{~N}_{3} \mathrm{~F}\right)_{\mathrm{n}}$ : $\mathrm{C}$ 78.62; $\mathrm{H}$ 4.02; $\mathrm{N} 11.96$, found: $\mathrm{C} 73.36 ; \mathrm{H}$ 4.25; $\mathrm{N} 8.82$. Characterization of LZU-561 was presented in the main text and in this SI.

The synthesis of ${ }^{13}$ C-labeled LZU-561 was similar to that of LZU-561. Condensat-ion of 2-amino-pyridine 1a, 1,3,5-tris(3-fluoro-4-formyl phenyl)benzene 2 and ${ }^{13} \mathrm{C}$-labeled $1,3,5$-tris (4-isocyanophenyl) benzene $3\left(-\mathrm{N} \equiv{ }^{13} \mathrm{C}\right)$ yielded ${ }^{13} \mathrm{C}$-labeled LZU-561. 


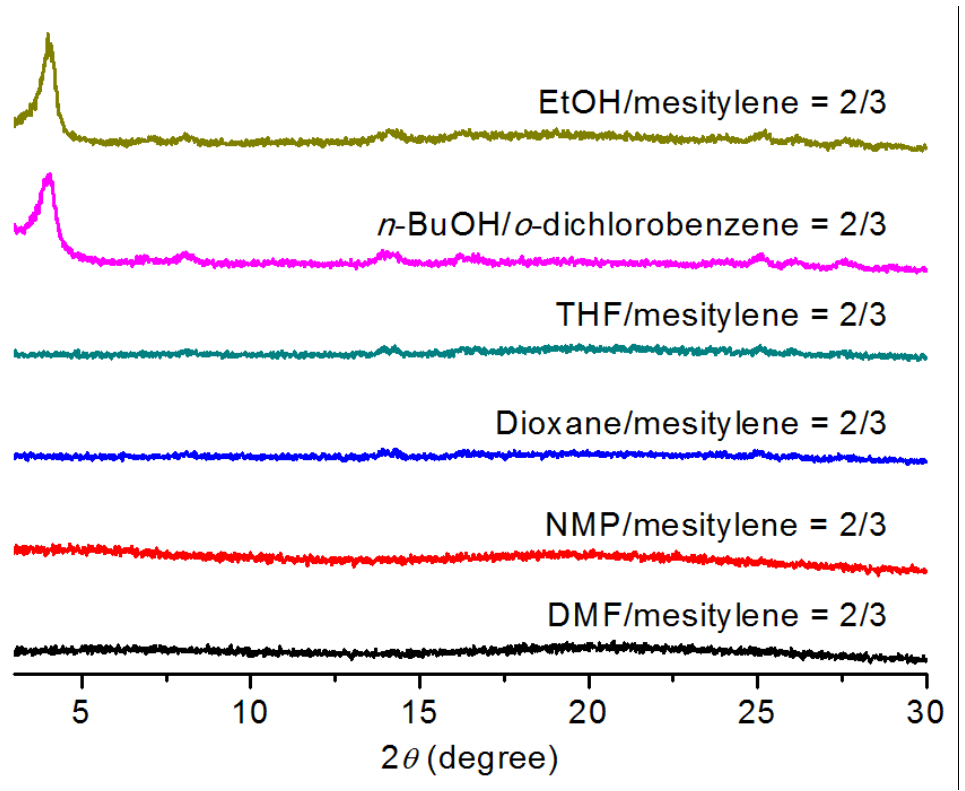

Figure S2. PXRD patterns of LZU-561 synthesized in different solvents $\left(120{ }^{\circ} \mathrm{C}, 5\right.$ days).

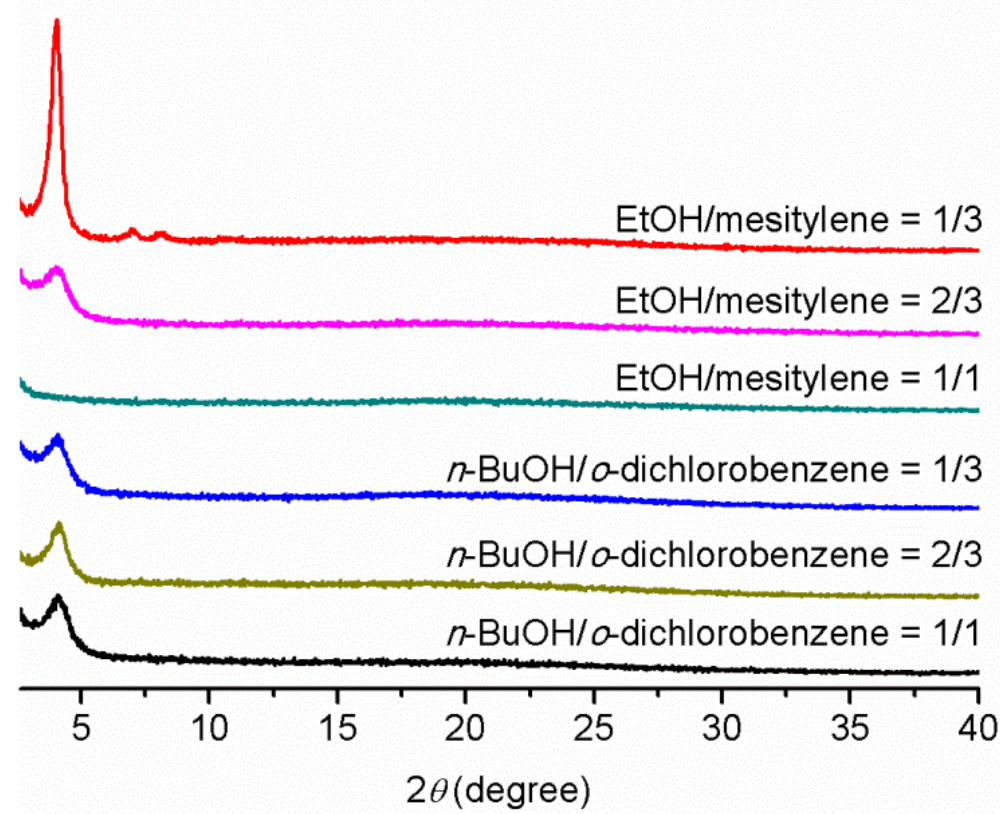

Figure S3. PXRD patterns of LZU-561 synthesized with indicated conditions $\left(120^{\circ} \mathrm{C}\right.$, 5 days). 


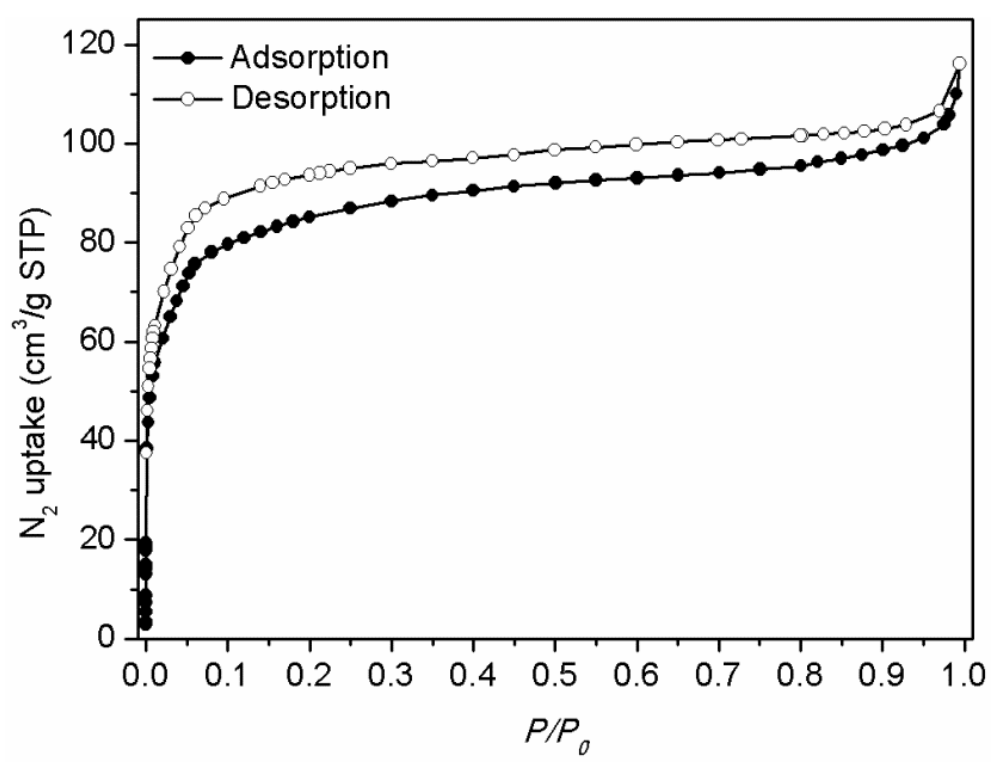

Figure S4. $\mathrm{N}_{2}$ adsorption and desorption isotherms of LZU-561.

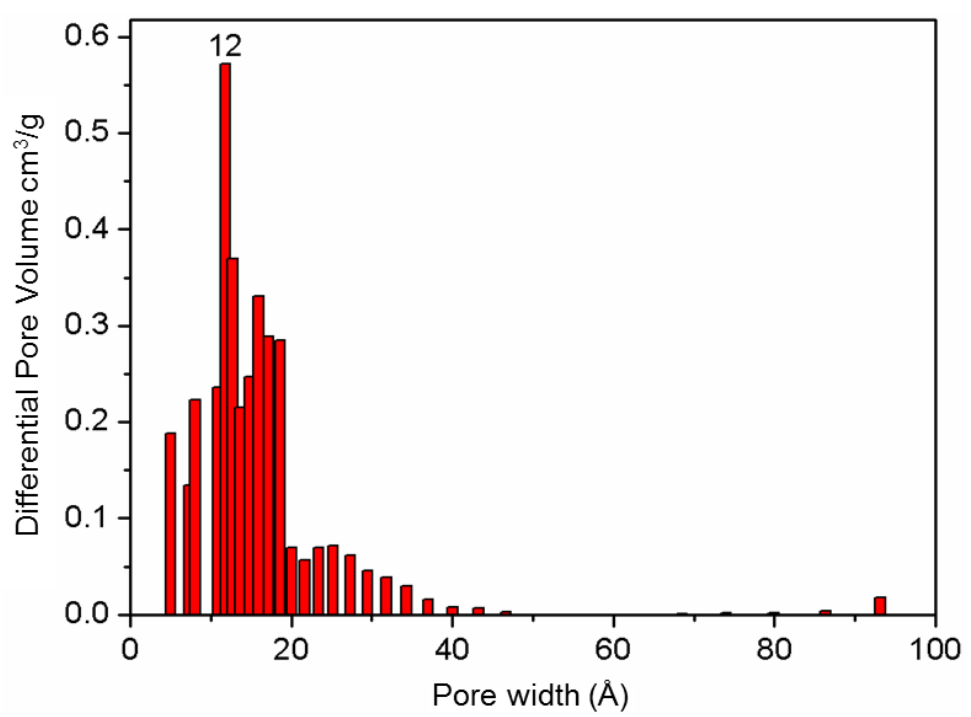

Figure S5. Pore size distribution of LZU-561 calculated by NLDFT (slit pores model). 


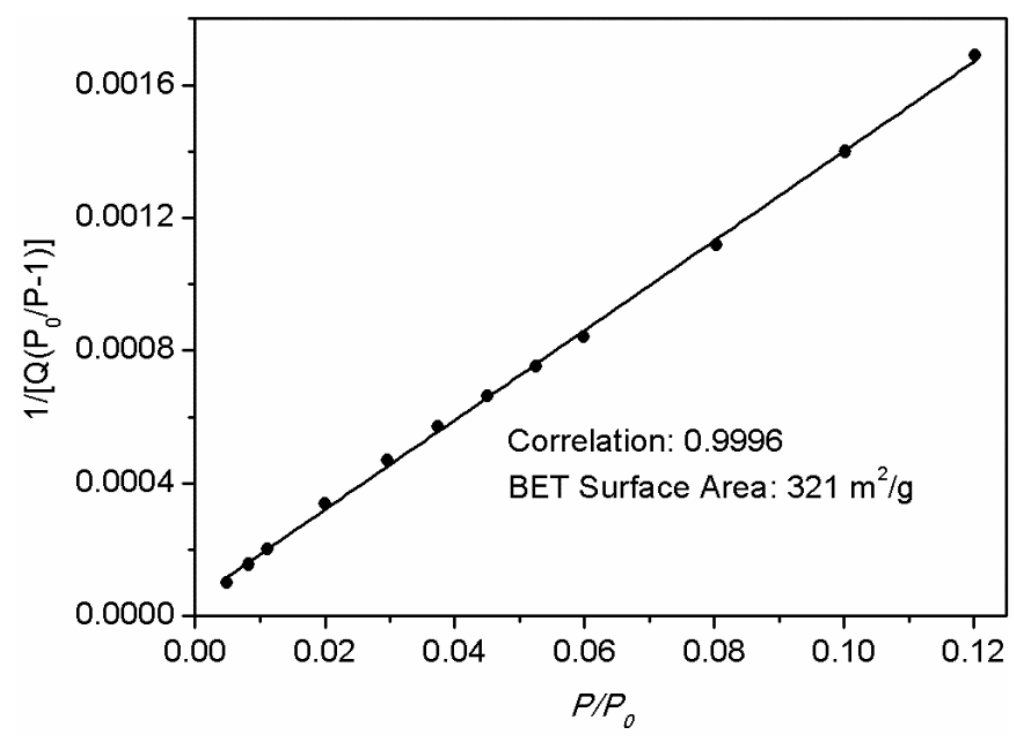

Figure S6. BET surface area plot for LZU-561 calculated from the adsorption isotherm.

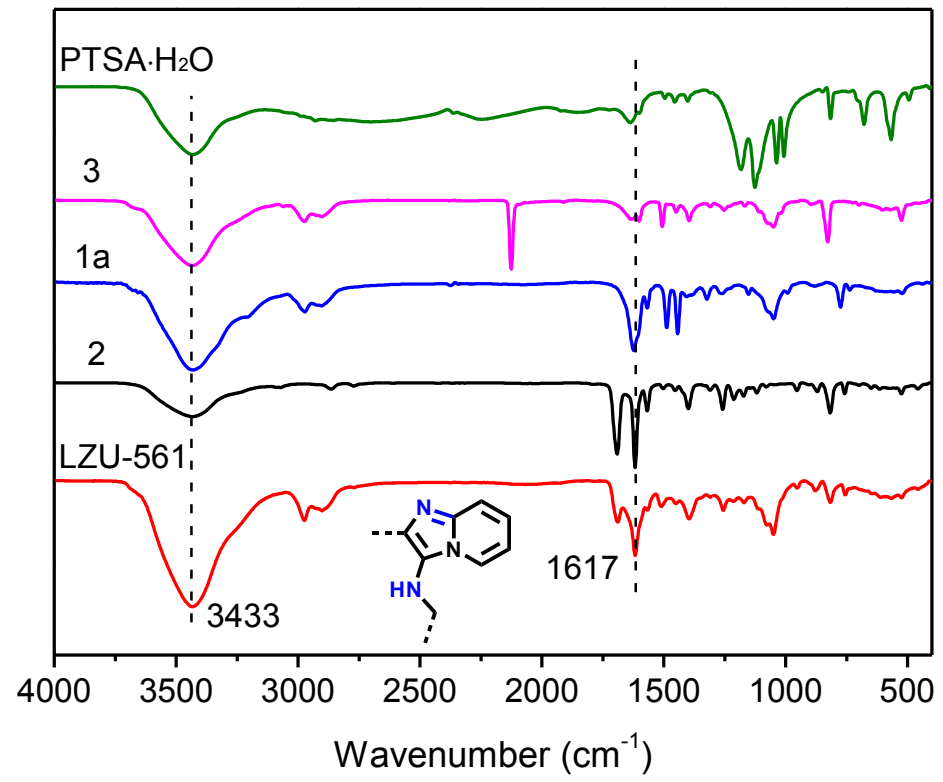

Figure S7. FT-IR spectra of LZU-561 (red), monomer 2 (black), monomer 1a (blue), monomer 3 (purple) and PTSA $\cdot \mathrm{H}_{2} \mathrm{O}$ (as the catalyst, green). The FT-IR spectrum of LZU-561 (red) showed stretch at $1617 \mathrm{~cm}^{-1}$, indicating the formation of pyrimidazole ring. 


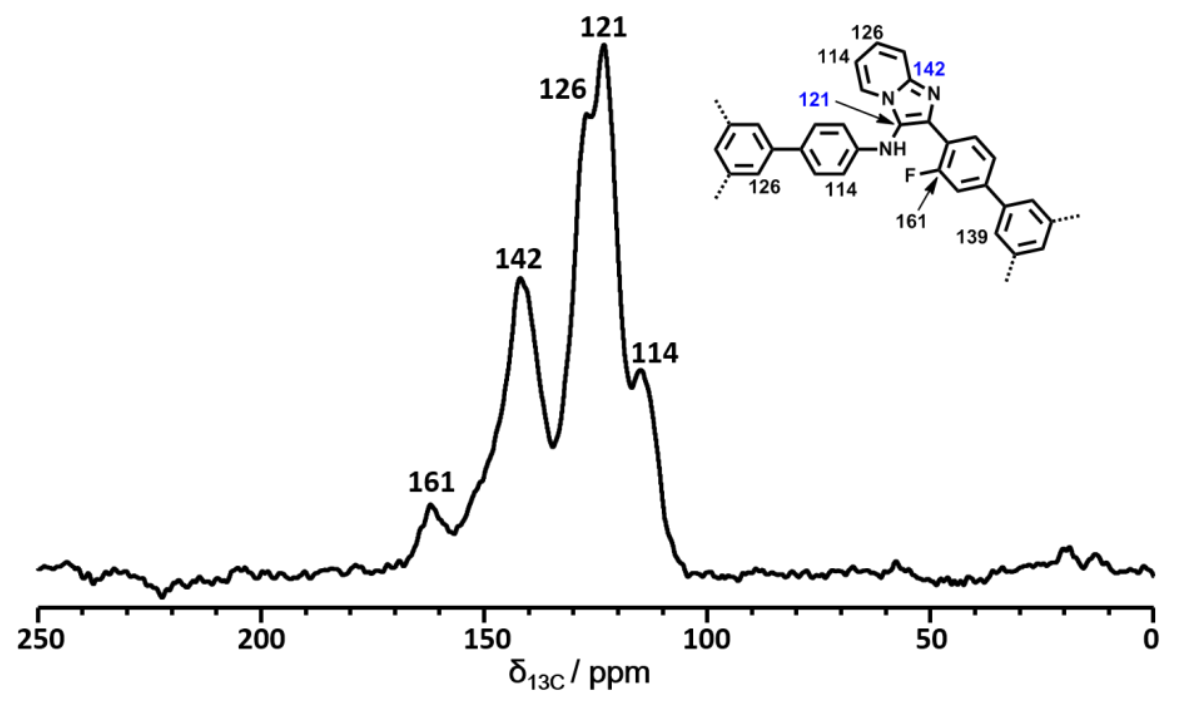

Figure S8. ${ }^{13} \mathrm{C}$ CP/MAS NMR spectrum of LZU-561. The assignments of ${ }^{13} \mathrm{C}$ chemical shifts were indicated in the chemical structure.

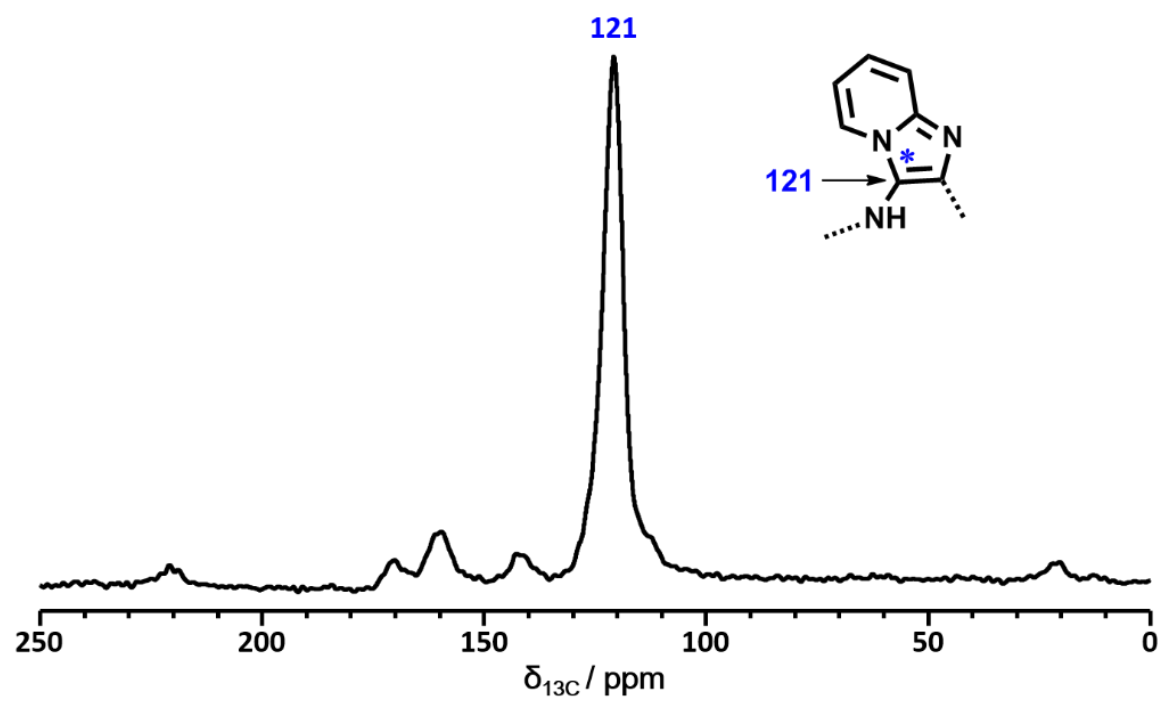

Figure S9. ${ }^{13} \mathrm{C}$ CP/MAS NMR spectrum of ${ }^{13} \mathrm{C}$-labeled LZU-561. The ${ }^{13} \mathrm{C}$-labeled LZU-561 was made by ${ }^{13} \mathrm{C}$-labeled $1,3,5$-tris(4-isocyanophenyl) benzene $\left(-\mathrm{N} \equiv{ }^{13} \mathrm{C}\right)$. The presence of the peak at $121 \mathrm{ppm}$ indicates the formation of pyrimidazole ring with the ${ }^{13} \mathrm{C}$-labeled atom as *. 


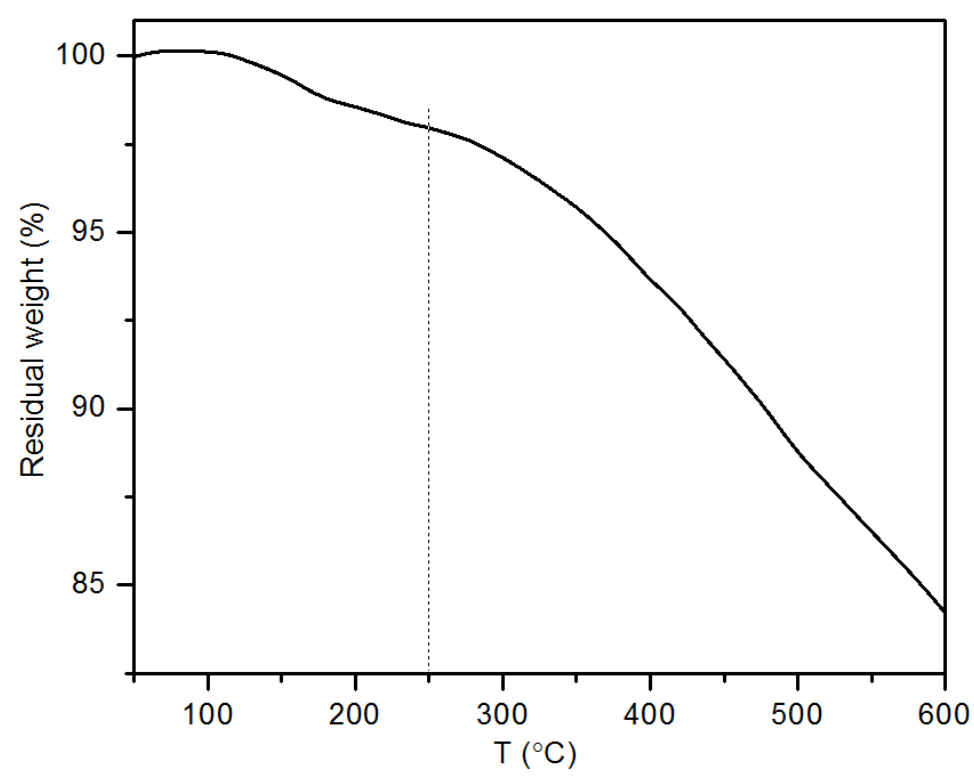

Figure S10. TGA data of LZU-561, indicating that LZU-561 is thermally stable up to $250^{\circ} \mathrm{C}$.
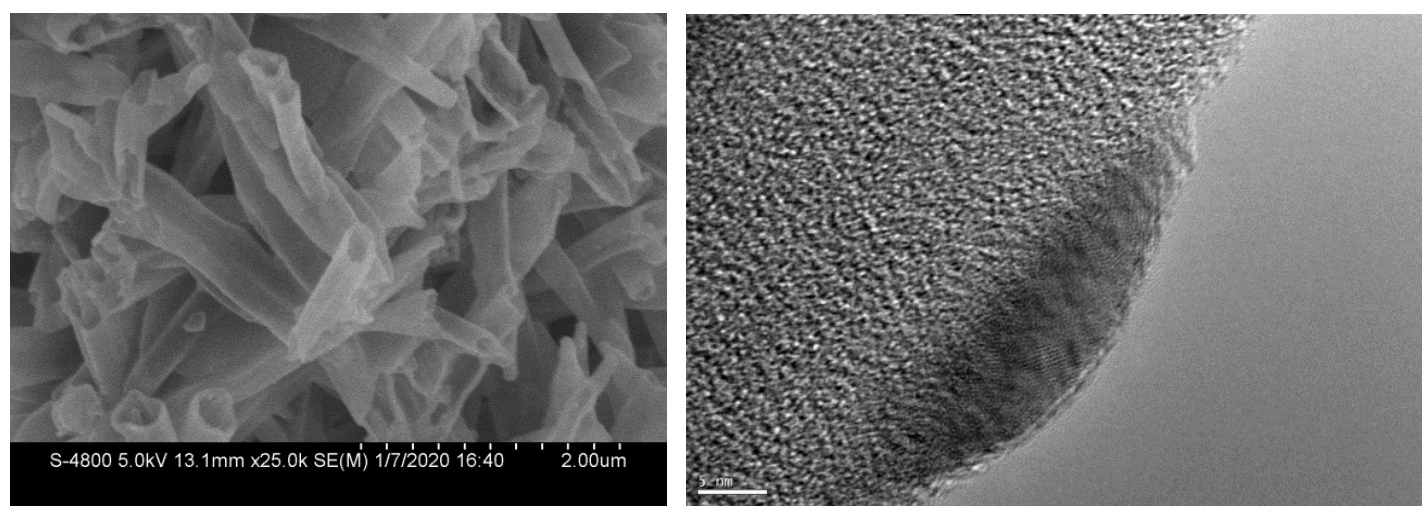

Figure S11. SEM (left) and TEM (right) images of LZU-561. 
Structural modeling of LZU-561 was generated by the Materials Studio (ver. 7.0) ${ }^{3}$ suite of programs. Possible stacking models (eclipsed and staggered) were constructed and optimized using the Forcite module; the calculated PXRD pattern was generated with the Reflex Plus module. Pawley refinement was applied for profile fitting, producing the refined PXRD profile with the lattice parameters of $a=b=25.396( \pm$ $0.429) \AA$ and $c=3.552( \pm 0.061) \AA$. Rwp and $R \mathrm{p}$ values converged to $8.73 \%$ and $6.90 \%$, respectively. Comparison of the observed and the simulated PXRD patterns (Figure S12) suggested that the preferable structure of LZU-561 is the eclipsed arrangement.

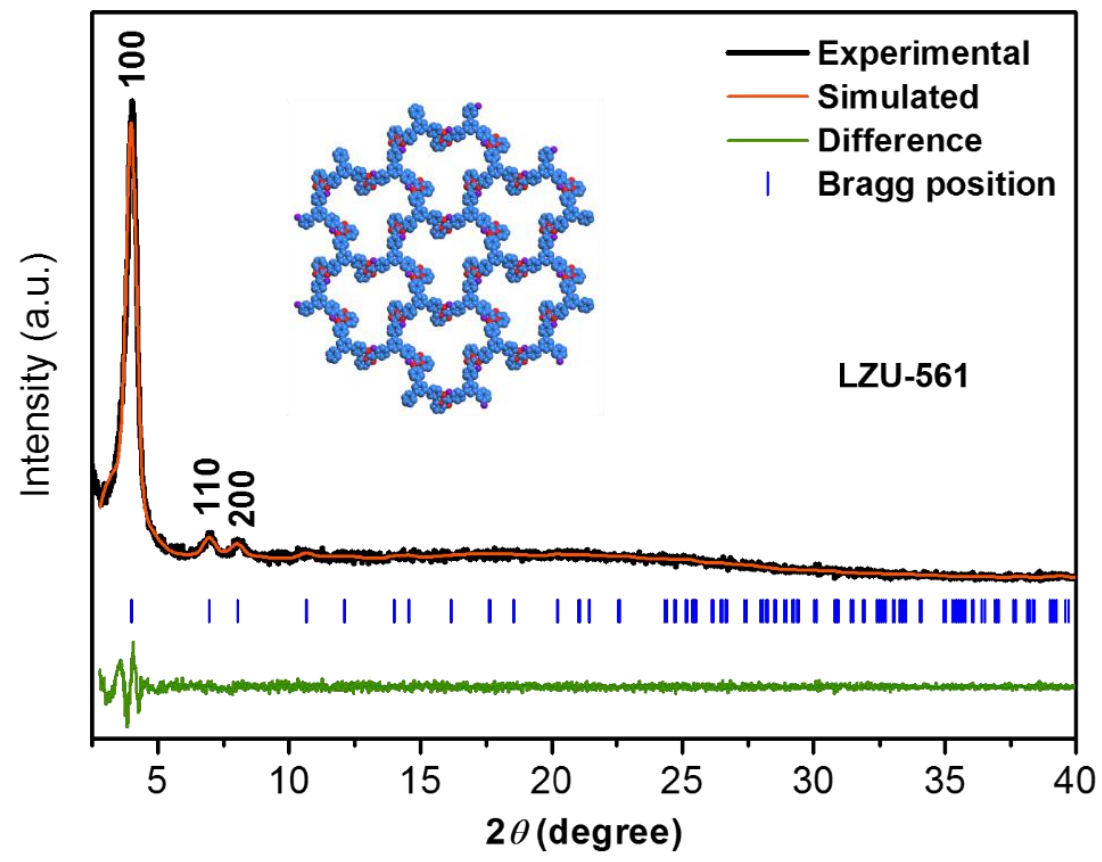

Figure S12. Indexed PXRD pattern and Pawley fitting profile of LZU-561. Inset: Structure of LZU-561 simulated with the eclipsed stacking model. C: blue, N: red, F: purple and $\mathrm{H}$ atoms are omitted for clarity. 


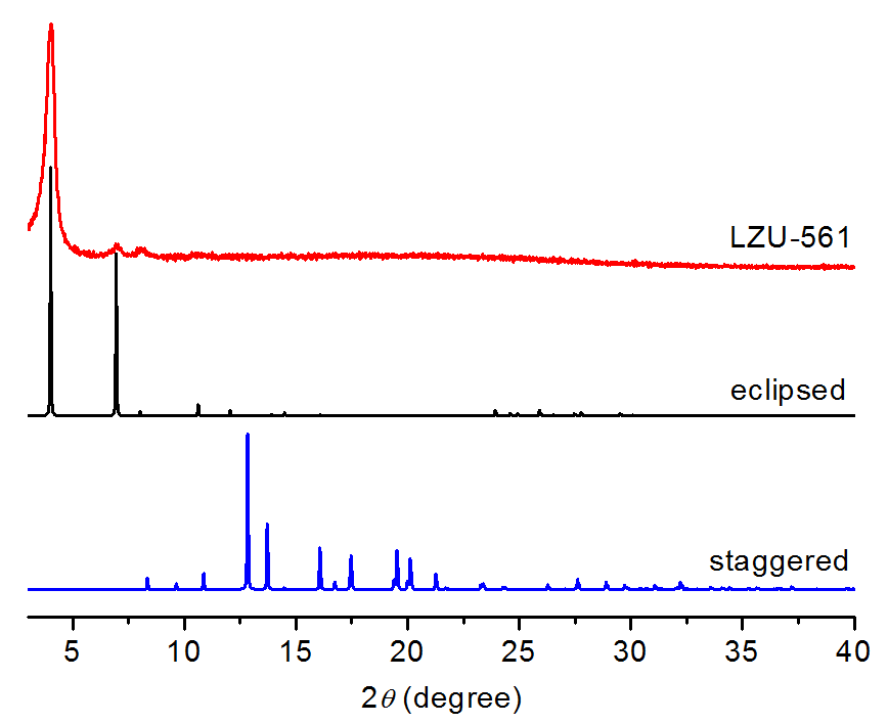

Figure S13. PXRD patterns of LZU-561: observed (red) and calculated with eclipsed (black)/staggered (blue) stacking model. Comparison of the observed and the simulated PXRD patterns suggested that the preferable structure of LZU-561 is the eclipsed arrangement.

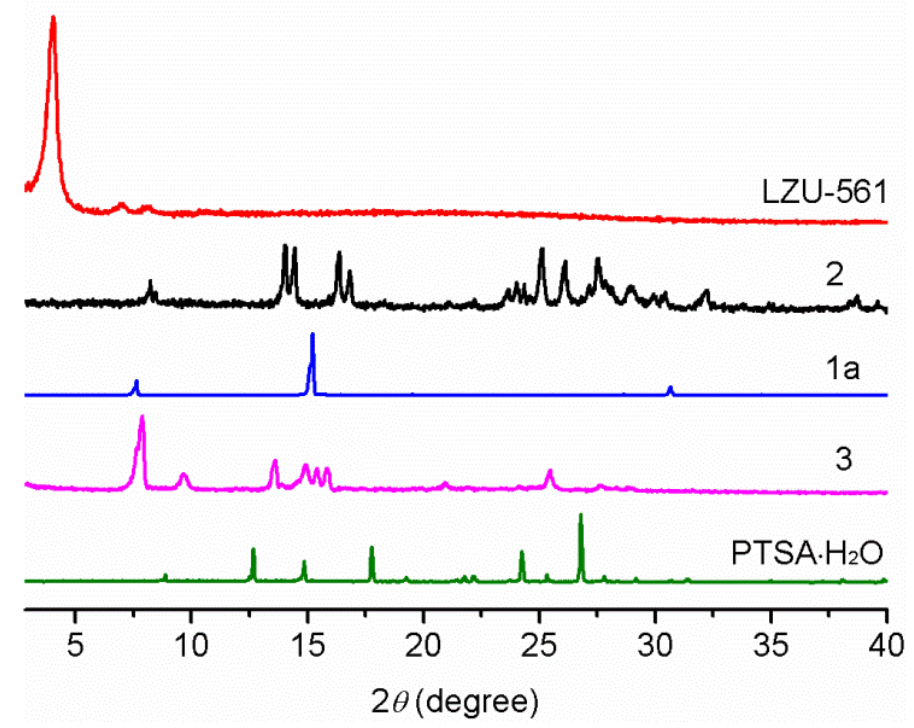

Figure S14. PXRD patterns of LZU-561 (red), monomer 2 (black), monomer 1a (blue), monomer 3 (purple), and PTSA $\cdot \mathrm{H}_{2} \mathrm{O}$ (as the catalyst, green). No diffraction peaks from 1a, 2, 3, and PTSA. $\mathrm{H}_{2} \mathrm{O}$ could be observed in the PXRD pattern of LZU-561, indicating the formation of new crystalline structure. 
Table S1. Fractional atomic coordinates for the unit cell of LZU-561.

\begin{tabular}{|c|c|c|c||c|c|c|c|}
\hline \multicolumn{7}{|c|}{ Space group: $P 3$} \\
\hline Atom & $\mathbf{X}(\AA)$ & $\mathbf{\AA}(\mathbf{\AA})$ & $\mathbf{Z}(\mathbf{\AA})$ & Atom & $\mathbf{X}(\AA)$ & $\mathbf{Y}(\AA)$ & $\mathbf{Z}(\mathbf{\AA})$ \\
\hline C1 & 0.94496 & -0.05656 & 0.41848 & C22 & 0.37981 & -0.2729 & 0.75205 \\
\hline C2 & 1.00148 & -0.05405 & 0.42449 & F23 & 0.71786 & -0.18158 & 0.53965 \\
\hline C3 & 0.88678 & -0.11595 & 0.37518 & C24 & 0.54961 & -0.3862 & 0.16788 \\
\hline C4 & 0.83081 & -0.12161 & 0.49662 & C25 & 0.51693 & -0.44638 & 0.01842 \\
\hline C5 & 0.77437 & -0.1763 & 0.42464 & C26 & 0.54953 & -0.4718 & -0.15553 \\
\hline C6 & 0.77423 & -0.22553 & 0.23887 & C27 & 0.61481 & -0.43704 & -0.18002 \\
\hline C7 & 0.83075 & -0.22025 & 0.12386 & H28 & 1.00264 & -0.09571 & 0.42463 \\
\hline C8 & 0.88718 & -0.16556 & 0.19584 & H29 & 0.82939 & -0.08617 & 0.64671 \\
\hline C9 & 0.7178 & -0.28022 & 0.16688 & H30 & 0.83071 & -0.25935 & -0.02387 \\
\hline C10 & 0.65823 & -0.29202 & 0.26452 & H31 & 0.93187 & -0.16134 & 0.10507 \\
\hline N11 & 0.6145 & -0.35182 & 0.14289 & H32 & 0.68228 & -0.20547 & 0.53428 \\
\hline C12 & 0.6471 & -0.37724 & -0.03106 & H33 & 0.60767 & -0.18093 & 0.80524 \\
\hline N13 & 0.71098 & -0.33315 & -0.01694 & H34 & 0.49991 & -0.21547 & 0.9521 \\
\hline N14 & 0.64485 & -0.25075 & 0.45251 & H35 & 0.43386 & -0.39161 & 0.42385 \\
\hline C15 & 0.58261 & -0.2687 & 0.53328 & H36 & 0.41562 & -0.22632 & 0.752 \\
\hline C16 & 0.56923 & -0.22743 & 0.72126 & H37 & 0.52523 & -0.51679 & -0.26967 \\
\hline C17 & 0.50843 & -0.24634 & 0.79923 & H38 & 0.54545 & 0.64044 & 0.27852 \\
\hline C18 & 0.45961 & -0.30385 & 0.68997 & H39 & 0.52391 & 0.63403 & 0.30573 \\
\hline C19 & 0.4723 & -0.34511 & 0.50782 & H40 & 0.46533 & 0.52622 & 0.03808 \\
\hline C20 & 0.53454 & -0.32716 & 0.42706 & H41 & 0.64067 & 0.54288 & -0.31767 \\
\hline C21 & 0.39488 & -0.31912 & 0.7444 & & & & \\
\hline
\end{tabular}




\section{E. Synthesis and Characterization of LZU-562}

Synthesis of LZU-562
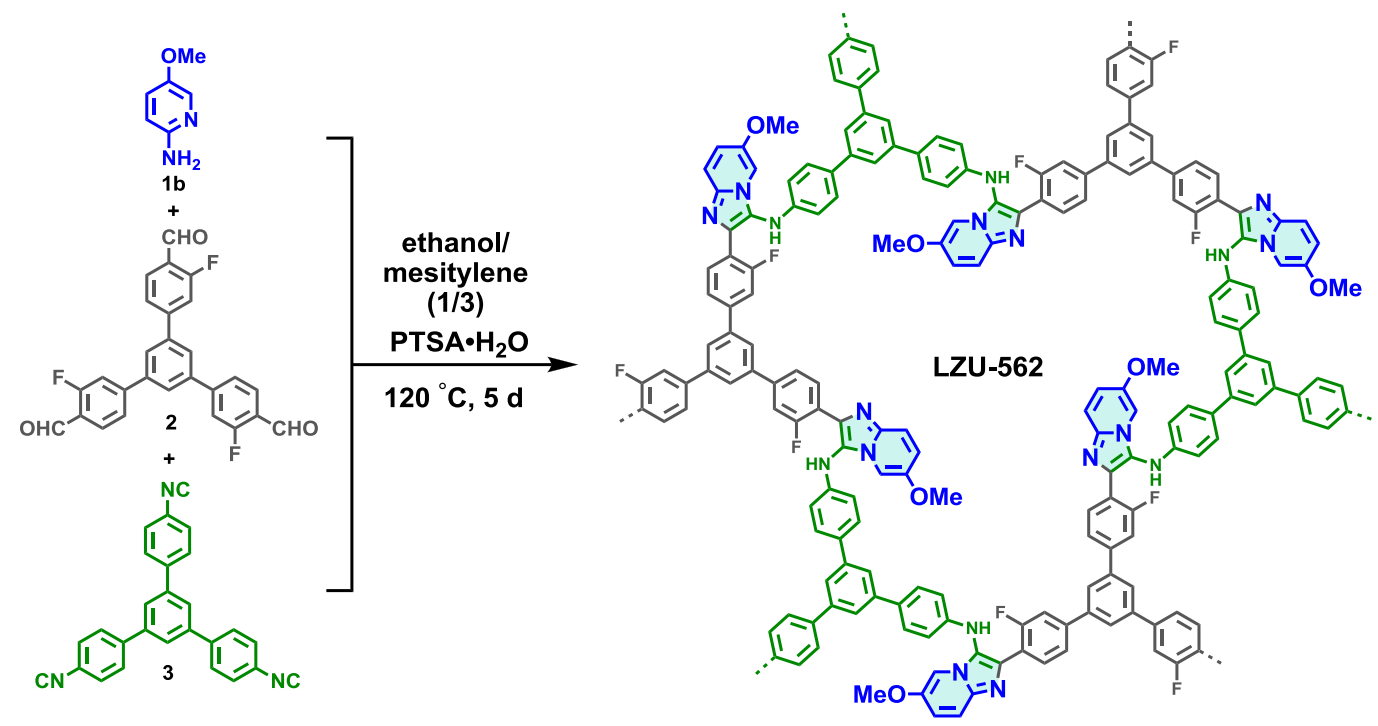

The synthetic procedure of LZU-562 was similar to that of LZU-561. Condensation of 2-amino-5-methoxypyridine $1 \mathrm{~b}(22.6 \mathrm{mg}, 0.182 \mathrm{mmol})$, 1,3,5-tris (3-fluoro-4-formylphenyl)benzene 2 (22.3 mg, $0.050 \mathrm{mmol})$, 1,3,5-tris(4-isocyano phenyl) benzene 3 (17.6 mg, $0.046 \mathrm{mmol}$ ) and p-toluenesulfonic acid monohydrate (7.0 mg, $0.037 \mathrm{mmol}$ ) yielded LZU-562 as a pale brown powder (40.5 mg, $77 \%$ yield). Anal. Cald for $\left(\mathrm{C}_{24} \mathrm{H}_{16} \mathrm{~N}_{3} \mathrm{OF}\right)_{\mathrm{n}}$ : C 75.58; H 4.23; N 11.02, found: $\mathrm{C} 74.25 ; \mathrm{H} \mathrm{4.28;} \mathrm{N}$ 8.98. Characterization of LZU-562 was presented in the main text and in this SI.

The synthesis of ${ }^{13}$ C-labeled LZU-562 was similar to that of LZU-562. Condensation of 2-amino-5-methoxypyridine 1b, 1,3,5-tris(3-fluoro-4-formyl phenyl)benzene 2 , and ${ }^{13} \mathrm{C}$-labeled 1,3,5-tris(4-isocyanophenyl) benzene $\mathbf{3}\left(-\mathrm{N} \equiv{ }^{13} \mathrm{C}\right)$ yielded ${ }^{13}$ C-labeled LZU-562. 
Characterization of LZU-562

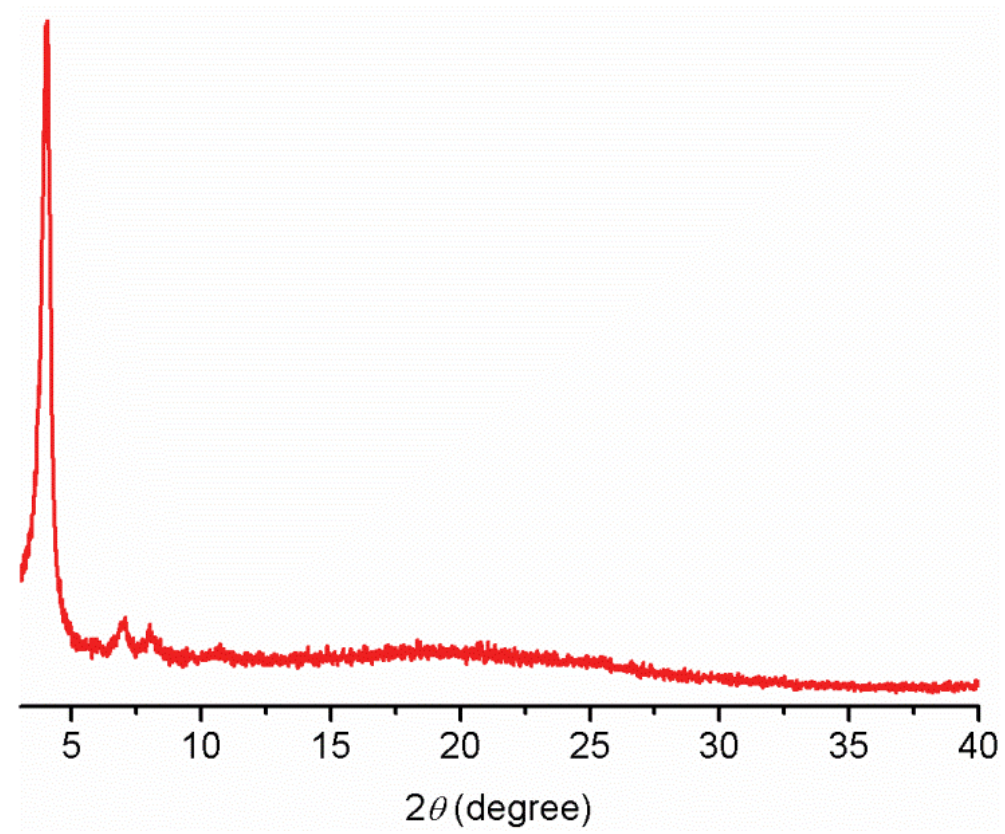

Figure S15. PXRD pattern of LZU-562 (ethanol/mesitylene (1/3), $120{ }^{\circ} \mathrm{C}, 5$ days).

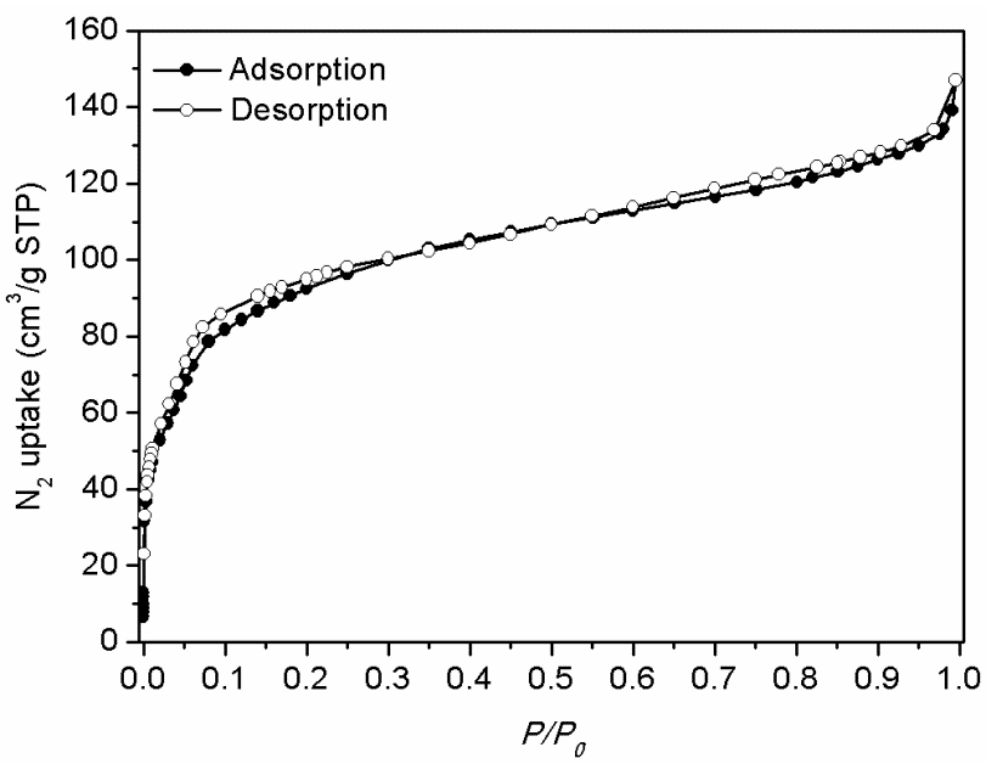

Figure S16. $\mathrm{N}_{2}$ adsorption and desorption isotherms of LZU-562. 


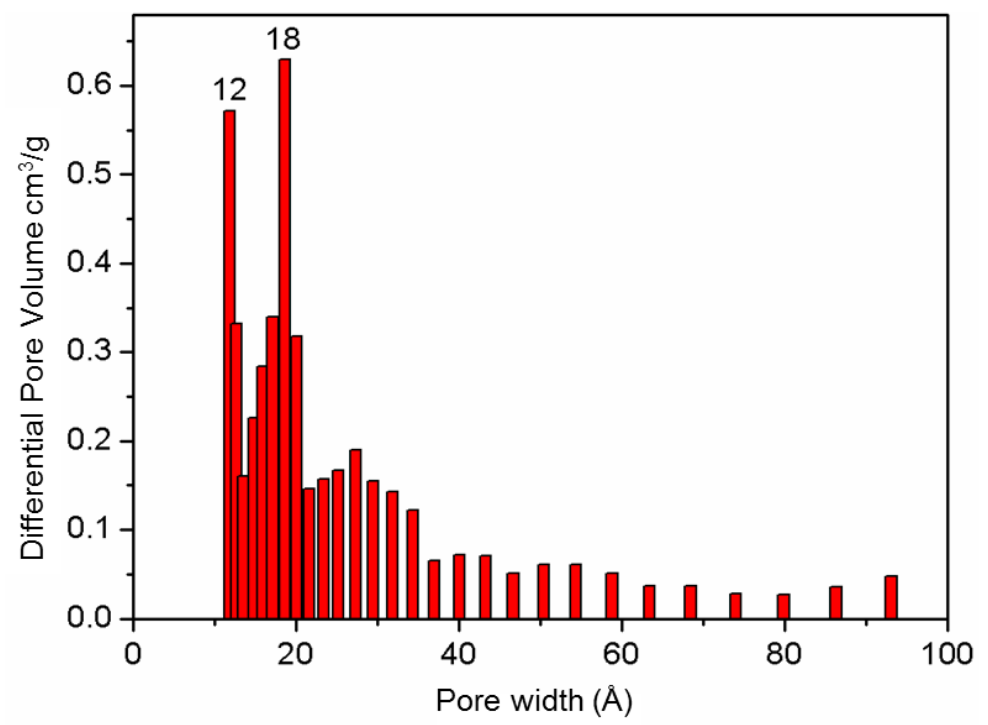

Figure S17. Pore size distribution of LZU-562 calculated by NLDFT (slit pores model).

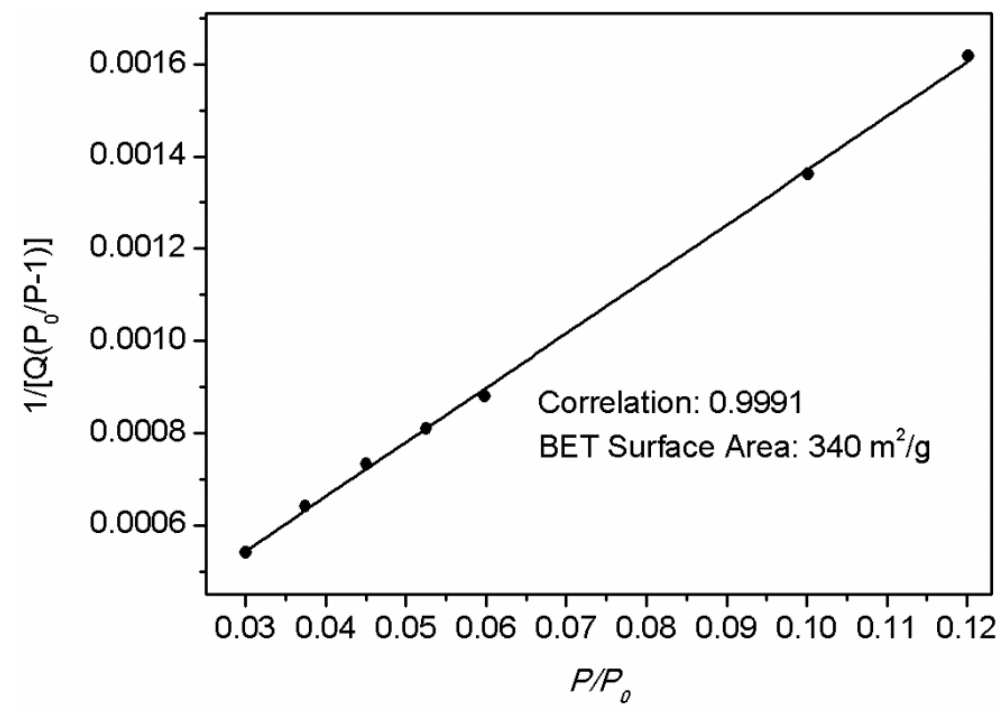

Figure S18. BET surface area plot for LZU-562 calculated from the adsorption isotherm. 


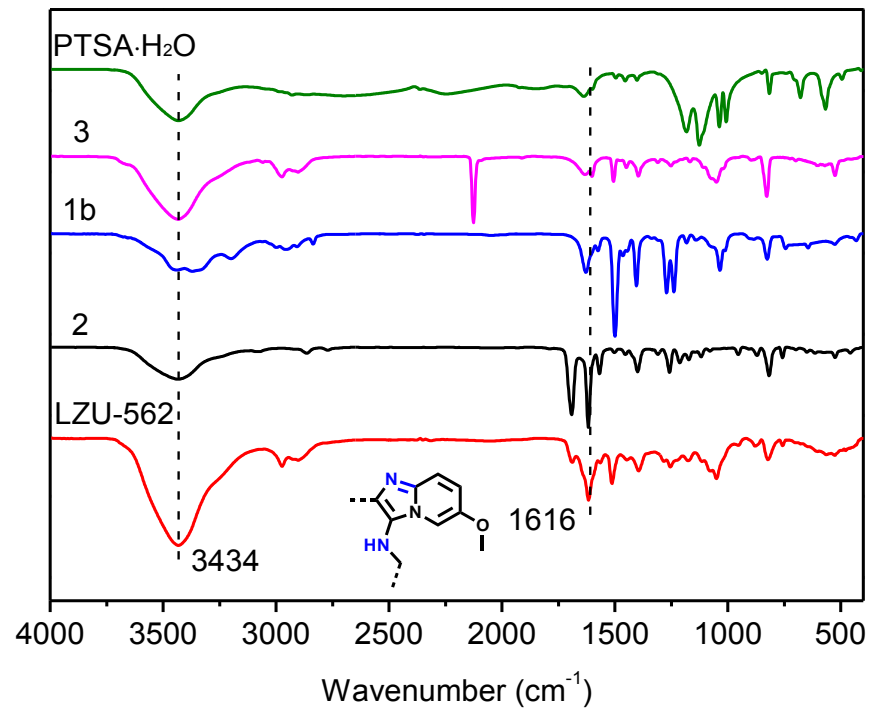

Figure S19. FT-IR spectra of LZU-562 (red), monomer 2 (black), monomer $\mathbf{1 b}$ (blue), monomer 3 (purple), and PTSA $\cdot \mathrm{H}_{2} \mathrm{O}$ (as the catalyst, green). The FT-IR spectrum of LZU-562 (red) shows stretch at $1616 \mathrm{~cm}^{-1}$, indicating the formation of pyrimidazole ring.

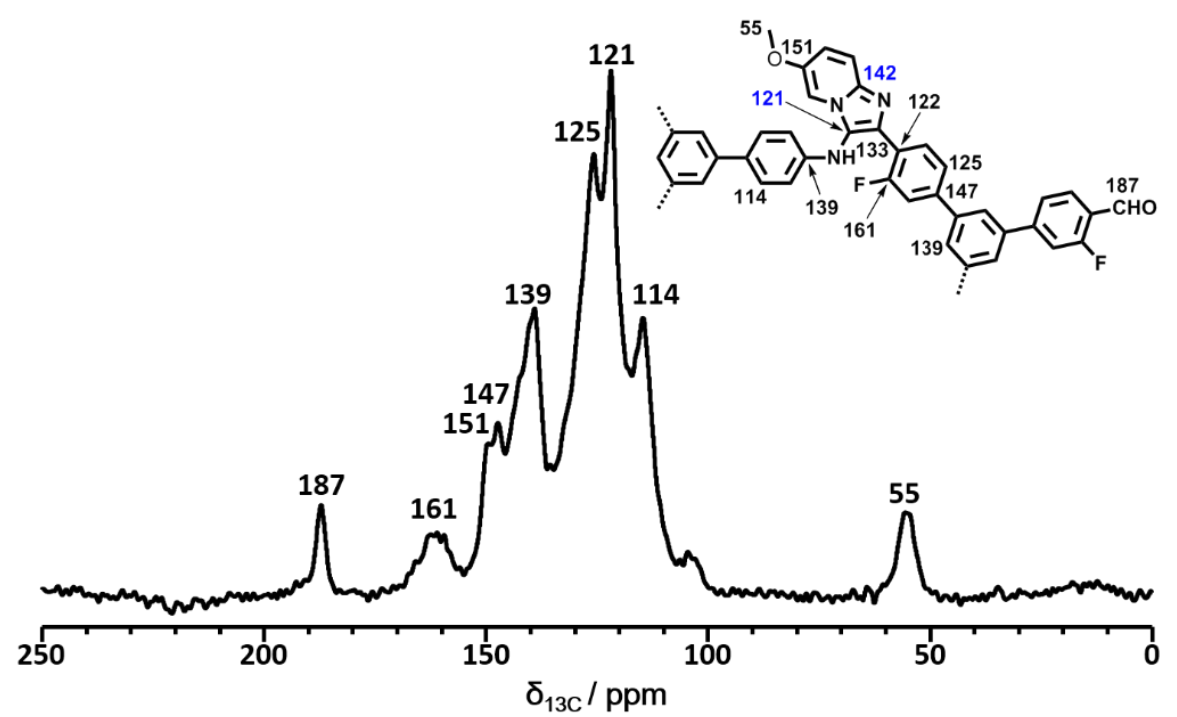

Figure S20. ${ }^{13} \mathrm{C}$ CP/MAS NMR spectrum of LZU-562. The assignments of ${ }^{13} \mathrm{C}$ chemical shifts were indicated in the chemical structure. 


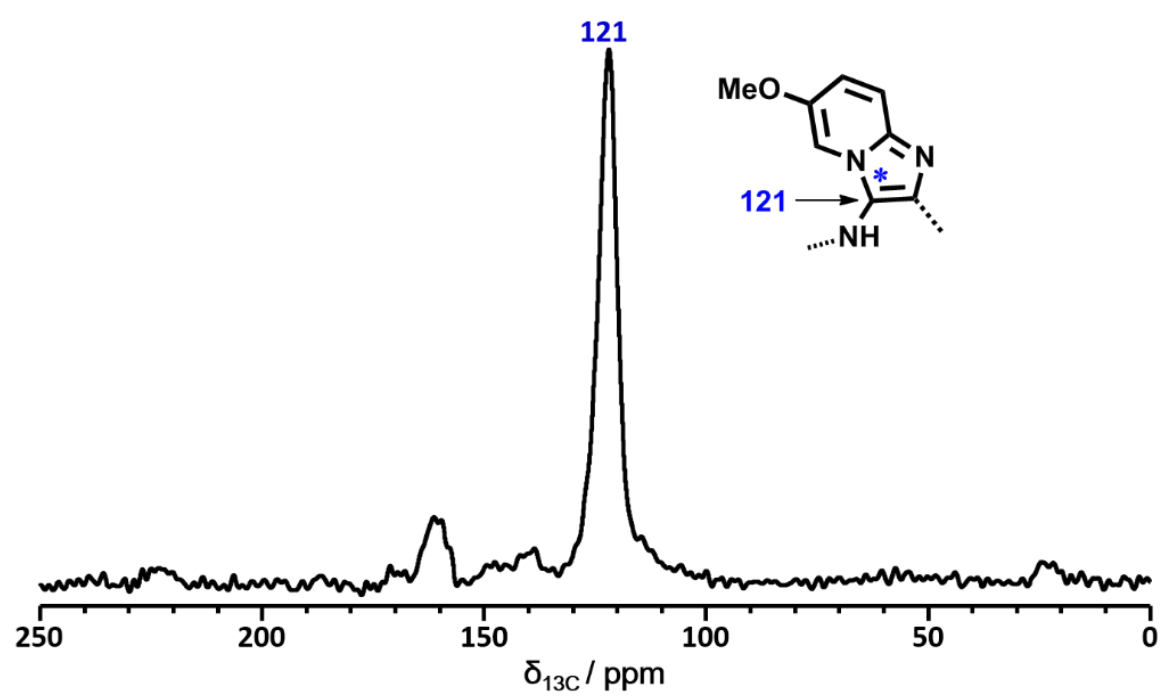

Figure S21. ${ }^{13} \mathrm{C} \mathrm{CP} / \mathrm{MAS}$ NMR spectrum of ${ }^{13} \mathrm{C}$-labeled LZU-562. The ${ }^{13} \mathrm{C}$ labeled LZU-562 was made by ${ }^{13} \mathrm{C}$-labeled $1,3,5$-tris(4-isocyanophenyl) benzene $\left(-\mathrm{N} \equiv{ }^{13} \mathrm{C}\right)$. The presence of the peak at $121 \mathrm{ppm}$ indicates the formation of pyrimidazole linkage with the ${ }^{13} \mathrm{C}$-labeled atom as *.

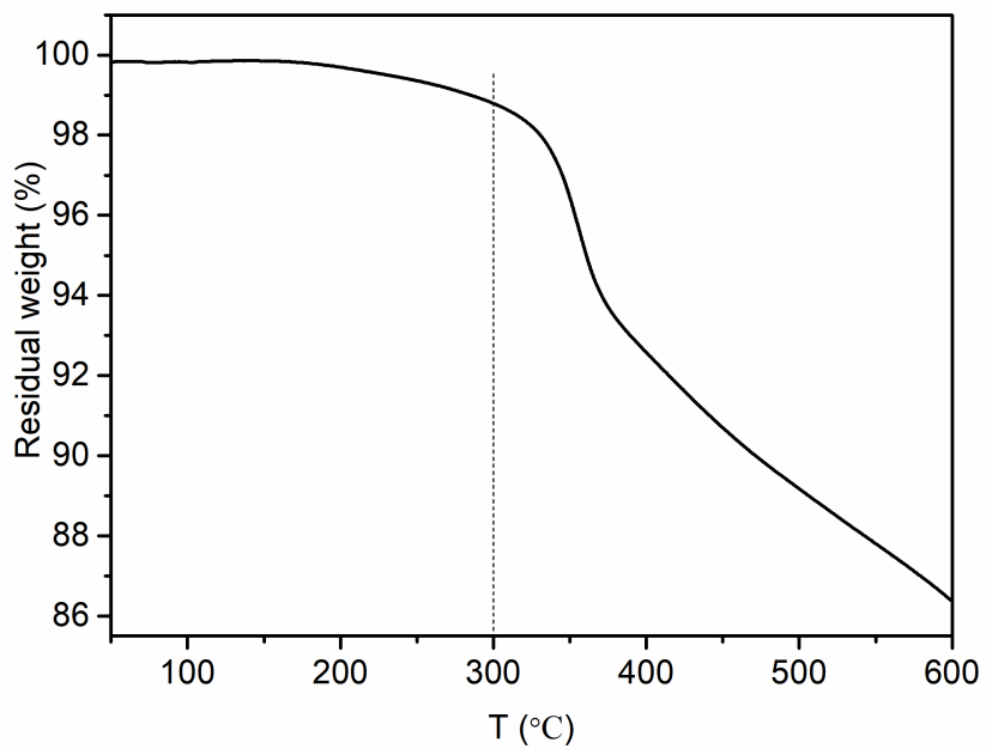

Figure S22. TGA data of LZU-562, indicating that LZU-562 is thermally stable up to $300^{\circ} \mathrm{C}$. 

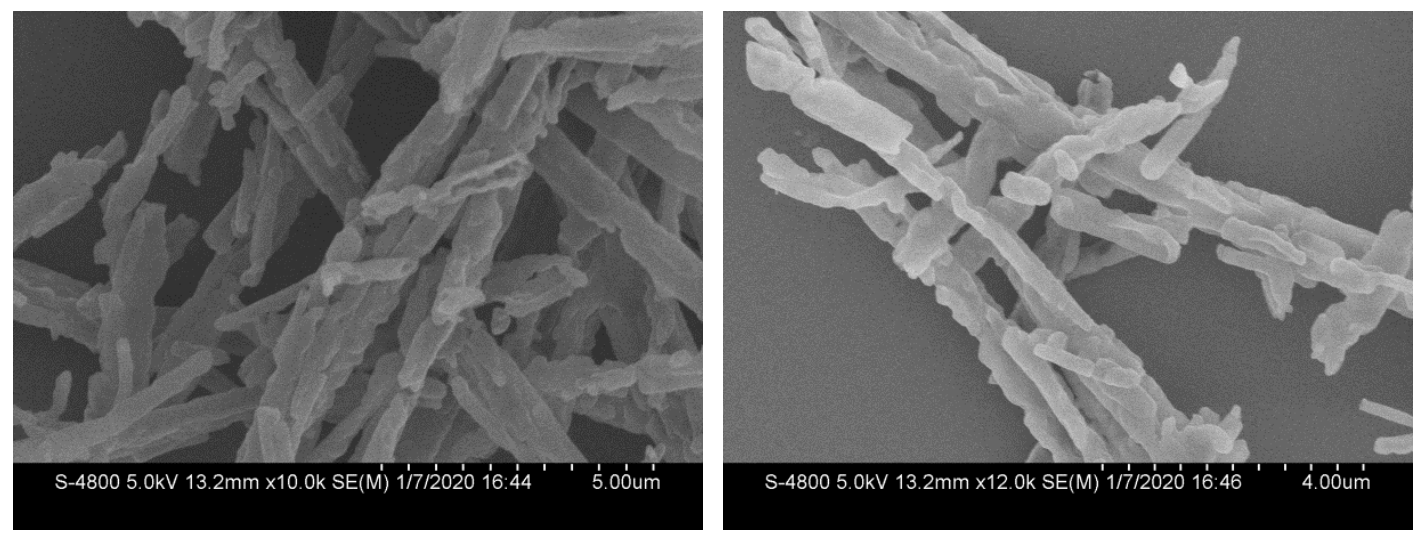

Figure S23. SEM images of LZU-562.
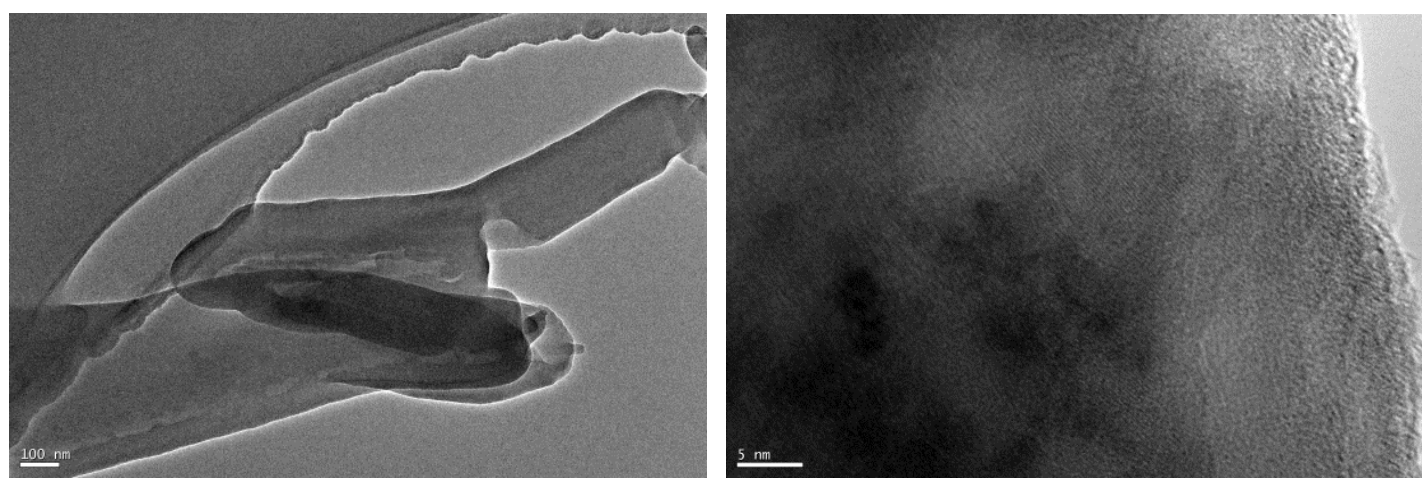

Figure S24. TEM images of LZU-562. 
The structural modeling of LZU-562 is similar to that of LZU-561. The Pawley refined lattice parameters were determined as: $a=b=25.650( \pm 0.442) \AA$ and $c=$ 4.122 ( \pm 0.071$) \AA . R \mathrm{wp}$ and $R \mathrm{p}$ values converged to $8.78 \%$ and $6.65 \%$, respectively. Comparison of the observed and the simulated PXRD patterns (Figure S25) suggested that the preferable structure of LZU-562 is the eclipsed arrangement.

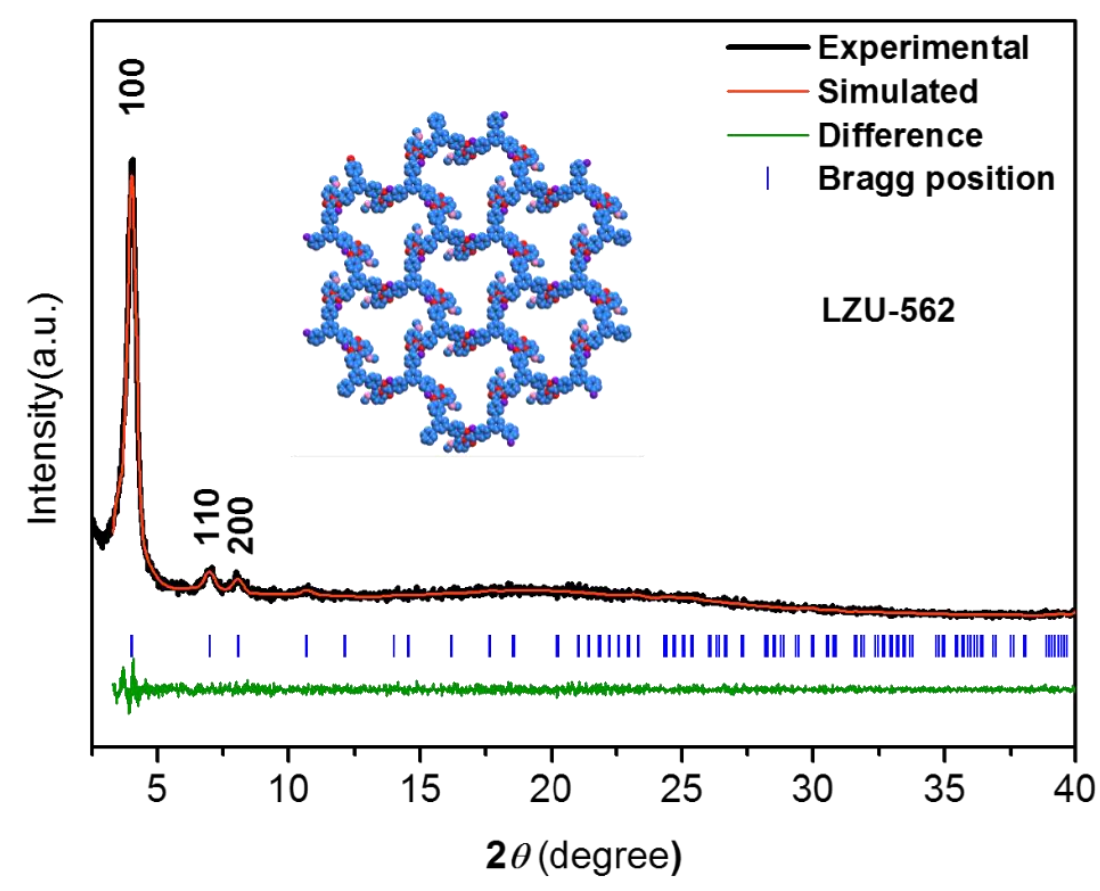

Figure S25. Indexed PXRD pattern and Pawley-refined profile of LZU-562. Inset: Structure of LZU-562 simulated with the eclipsed stacking model. C: blue, N: red, F: purple, $\mathrm{O}$ : pink and $\mathrm{H}$ atoms are omitted for clarity. 


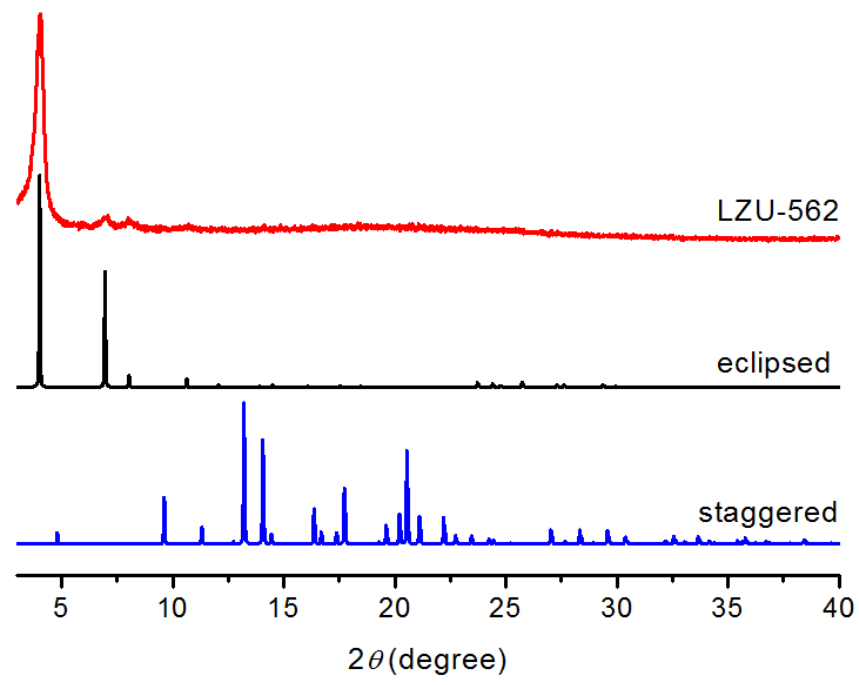

Figure S26. PXRD patterns of LZU-562: observed (red) and calculated with the eclipsed (black)/staggered (blue) stacking models. Comparison of the observed and the simulated PXRD patterns suggests that the preferable structure of LZU-562 is the eclipsed arrangement.

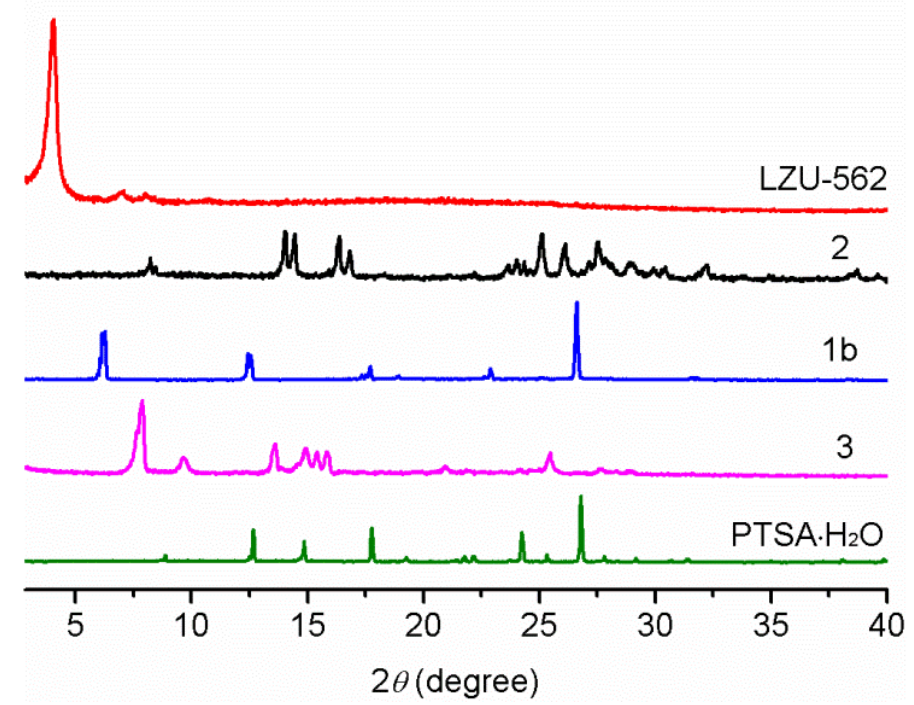

Figure S27. PXRD patterns of LZU-562 (red), monomer 2 (black), monomer 1b (blue), monomer 3 (purple), and PTSA $\cdot \mathrm{H}_{2} \mathrm{O}$ (as the catalyst, green). No diffraction peaks from 1b, 2, 3, and PTSA $\mathrm{H}_{2} \mathrm{O}$ could be observed in the PXRD pattern of LZU-562, indicating the formation of new crystalline structure. 
Table S2. Fractional atomic coordinates for the unit cell of LZU-562.

\begin{tabular}{|c|c|c|c||c|c|c|c|}
\hline \multicolumn{7}{|c|}{ Space group: $P 3$} \\
\hline Atom & $\mathbf{X}(\mathbf{\AA})$ & $\mathbf{Y}(\AA)$ & $\mathbf{Z}(\AA)$ & Atom & X $(\AA)$ & Y $(\AA)$ & Z $(\mathbf{A})$ \\
\hline C1 & 0.94525 & -0.05649 & 0.48794 & C24 & 0.55351 & -0.37986 & 0.08232 \\
\hline C2 & 1.0017 & -0.05377 & 0.4962 & C25 & 0.5222 & -0.43808 & -0.08557 \\
\hline C3 & 0.88767 & -0.11546 & 0.42803 & C26 & 0.55613 & -0.46198 & -0.2538 \\
\hline C4 & 0.83088 & -0.12183 & 0.5321 & C27 & 0.62137 & -0.42766 & -0.25414 \\
\hline C5 & 0.77526 & -0.17513 & 0.4356 & H28 & 1.00297 & -0.09525 & 0.49555 \\
\hline C6 & 0.77667 & -0.22237 & 0.24248 & H29 & 0.82819 & -0.08798 & 0.68668 \\
\hline C7 & 0.83393 & -0.21646 & 0.1447 & H30 & 0.83513 & -0.25397 & -0.00885 \\
\hline C8 & 0.88955 & -0.16315 & 0.2412 & H31 & 0.93482 & -0.15844 & 0.16406 \\
\hline C9 & 0.72106 & -0.27567 & 0.14597 & H32 & 0.6826 & -0.2045 & 0.51411 \\
\hline C10 & 0.6609 & -0.28789 & 0.22453 & H33 & 0.60602 & -0.18206 & 0.76701 \\
\hline N11 & 0.61836 & -0.3459 & 0.08131 & H34 & 0.49739 & -0.21702 & 0.87684 \\
\hline C12 & 0.65229 & -0.3698 & -0.08692 & H35 & 0.43606 & -0.38677 & 0.30381 \\
\hline N13 & 0.7158 & -0.32656 & -0.04768 & H36 & 0.41449 & -0.22602 & 0.63917 \\
\hline N14 & 0.646 & -0.24849 & 0.41474 & H37 & 0.53288 & -0.50548 & -0.38163 \\
\hline C15 & 0.58333 & -0.26664 & 0.47474 & H38 & 0.54844 & 0.64564 & 0.1957 \\
\hline C16 & 0.56843 & -0.22724 & 0.66495 & H39 & 0.52675 & 0.63917 & 0.2157 \\
\hline C17 & 0.5072 & -0.24635 & 0.72231 & H40 & 0.47064 & 0.53487 & -0.08498 \\
\hline C18 & 0.4595 & -0.30215 & 0.59055 & O41 & 0.64827 & 0.55347 & -0.38725 \\
\hline C19 & 0.47365 & -0.34159 & 0.40587 & C42 & 0.43974 & 0.47438 & 0.05233 \\
\hline C20 & 0.53633 & -0.32344 & 0.34587 & H43 & 0.47006 & 0.45872 & 0.15896 \\
\hline C21 & 0.39482 & -0.31828 & 0.63481 & H44 & 0.4118 & 0.44241 & -0.15391 \\
\hline C22 & 0.3791 & -0.27278 & 0.64076 & H45 & 0.40881 & 0.4721 & 0.26049 \\
\hline F23 & 0.718 & -0.18104 & 0.53338 & & & & \\
\hline & & & & & & \\
\hline
\end{tabular}


Synthesis of LZU-563
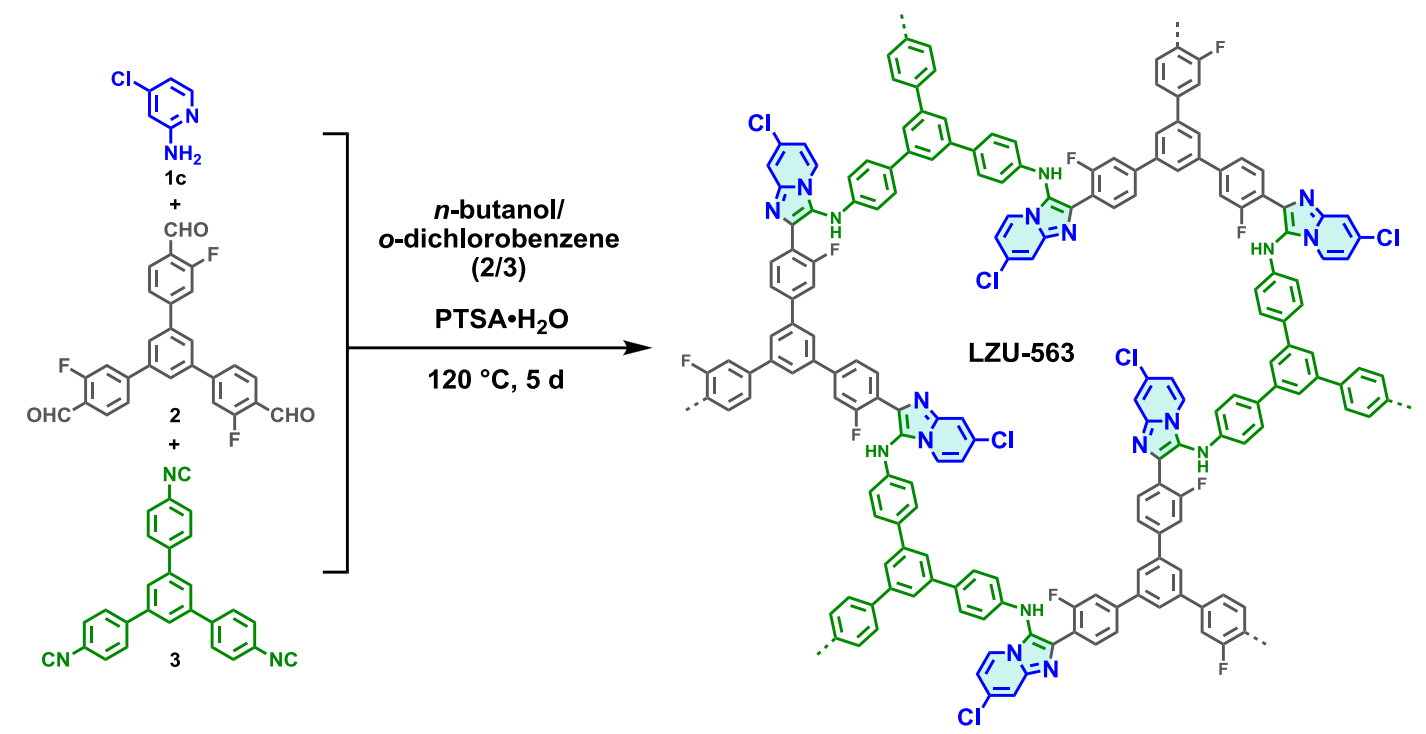

The synthetic procedure of LZU-563 was similar to that of LZU-561. Condensation of 2-amino-4-chloropyridine 1c (19.5 mg, $0.151 \mathrm{mmol})$, 1,3,5-tris (3-fluoro-4-formylphenyl)benzene 2 (11.3 mg, $0.025 \mathrm{mmol})$, 1,3,5-tris(4-isocyano phenyl)benzene $\mathbf{3}(9.7 \mathrm{mg}, 0.025 \mathrm{mmol})$ and $p$-toluenesulfonic acid monohydrate (3.5 mg, $0.018 \mathrm{mmol}$ ) yielded LZU-563 as a yellow powder, (20.3 mg, 70\% yield). Anal. Cald for $\left(\mathrm{C}_{23} \mathrm{H}_{13} \mathrm{~N}_{3} \mathrm{FCl}\right)_{n}$ : C 71.60; H 3.40; N 10.89, found: C 71.77; H 4.05; N 7.52. Characterization of LZU-563 was presented in the main text and in this SI.

The synthesis of ${ }^{13}$ C-labeled LZU-563 was similar to that of LZU-563. Condensation of 2-amino-4-chloropyridine 1c, 1,3,5-tris(3-fluoro-4-formylphenyl) benzene 2 , and ${ }^{13} \mathrm{C}$-labeled 1,3,5-tris(4-isocyanophenyl) benzene $3\left(-\mathrm{N} \equiv{ }^{13} \mathrm{C}\right)$ yielded ${ }^{13}$ C-labeled LZU-563. 
Characterization of $L Z U-563$

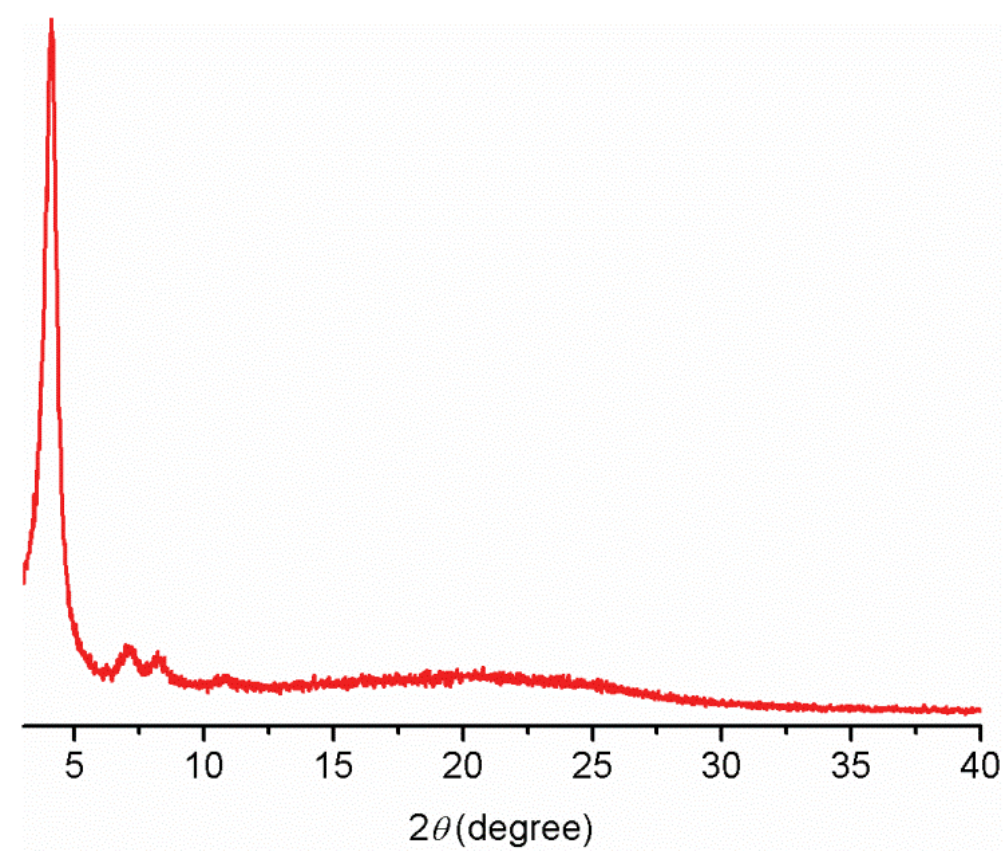

Figure S28. PXRD pattern of LZU-563 ( $n$-butanol/o-dichlorobenzene (2/3), $120{ }^{\circ} \mathrm{C}, 5$ days).

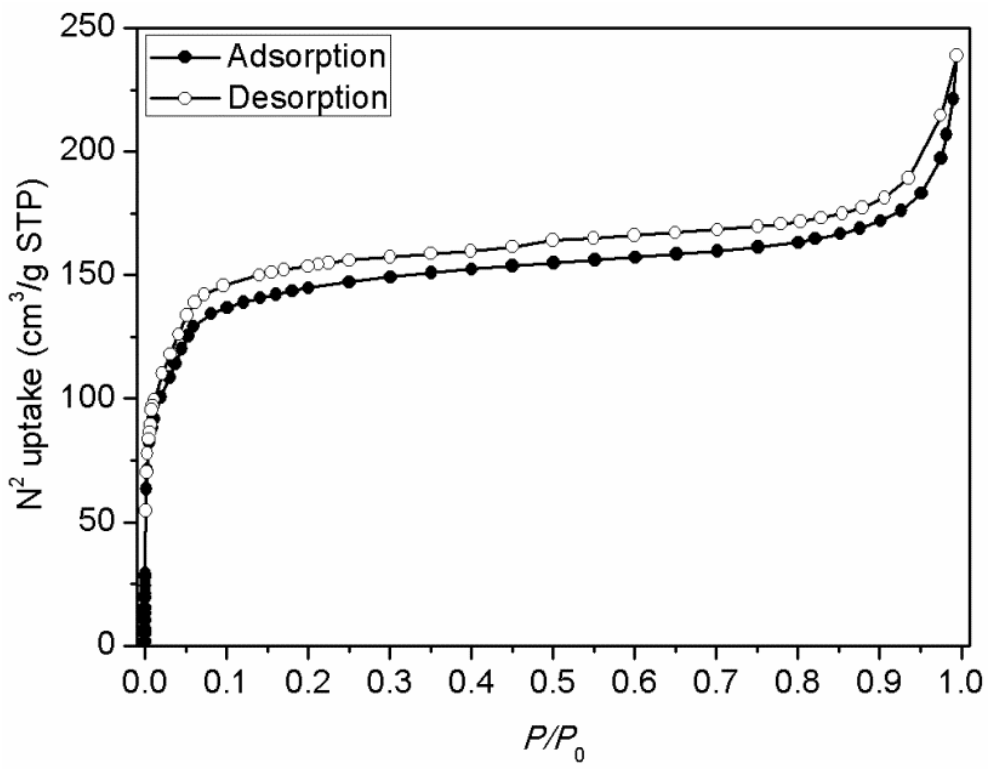

Figure S29. $\mathrm{N}_{2}$ adsorption and desorption isotherms of LZU-563. 


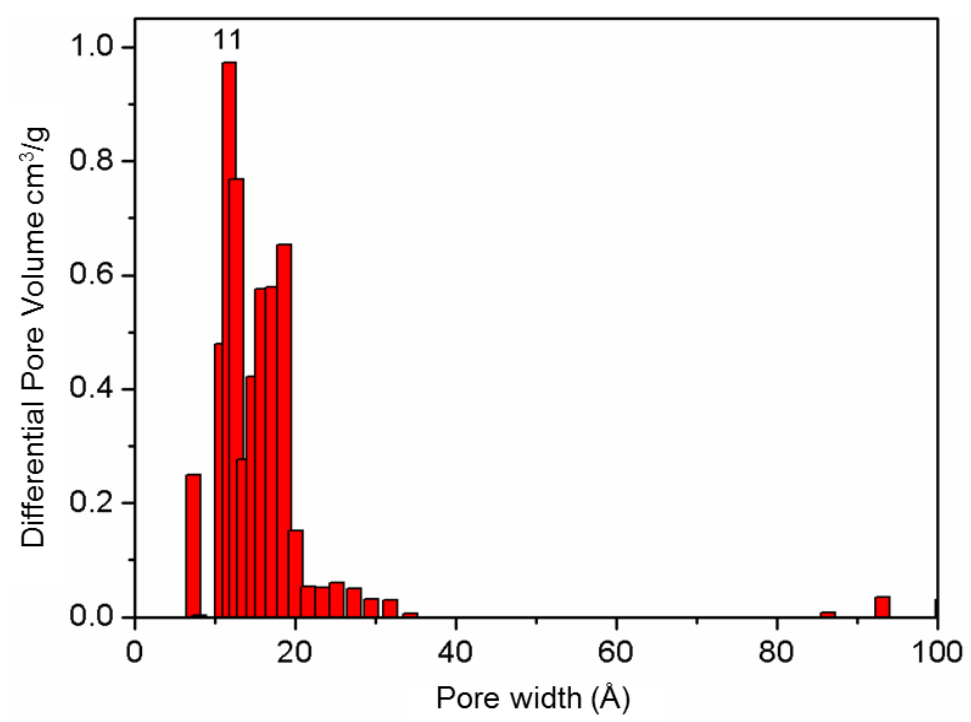

Figure S30. Pore size distribution of LZU-563 calculated by NLDFT (slit pores model).

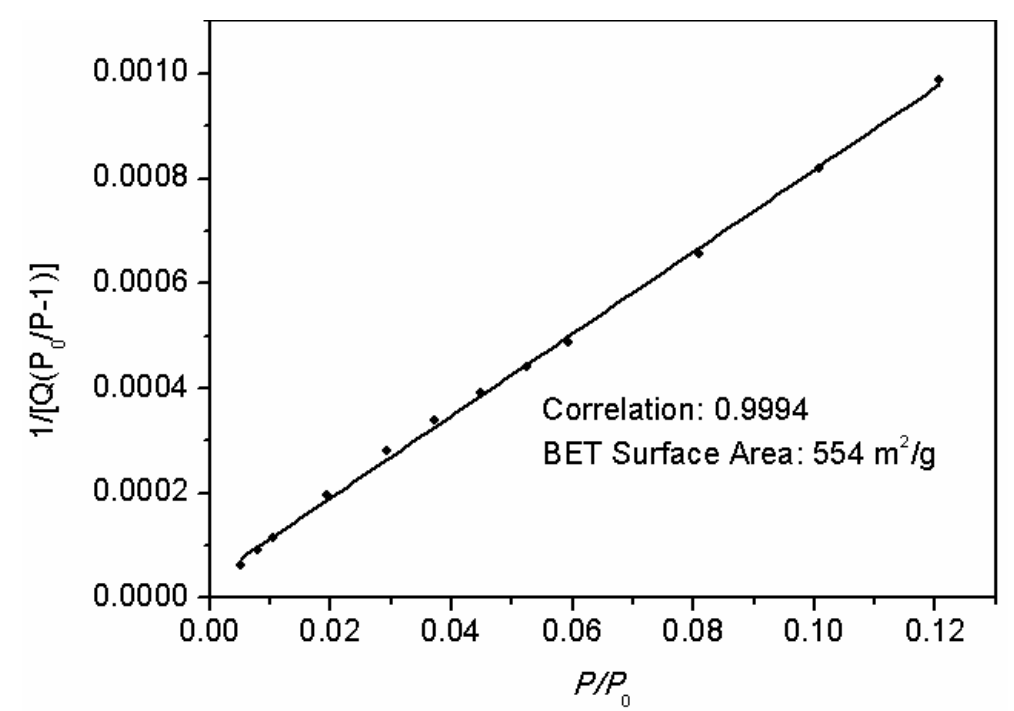

Figure S31. BET surface area plot for LZU-563 calculated from the adsorption isotherm. 


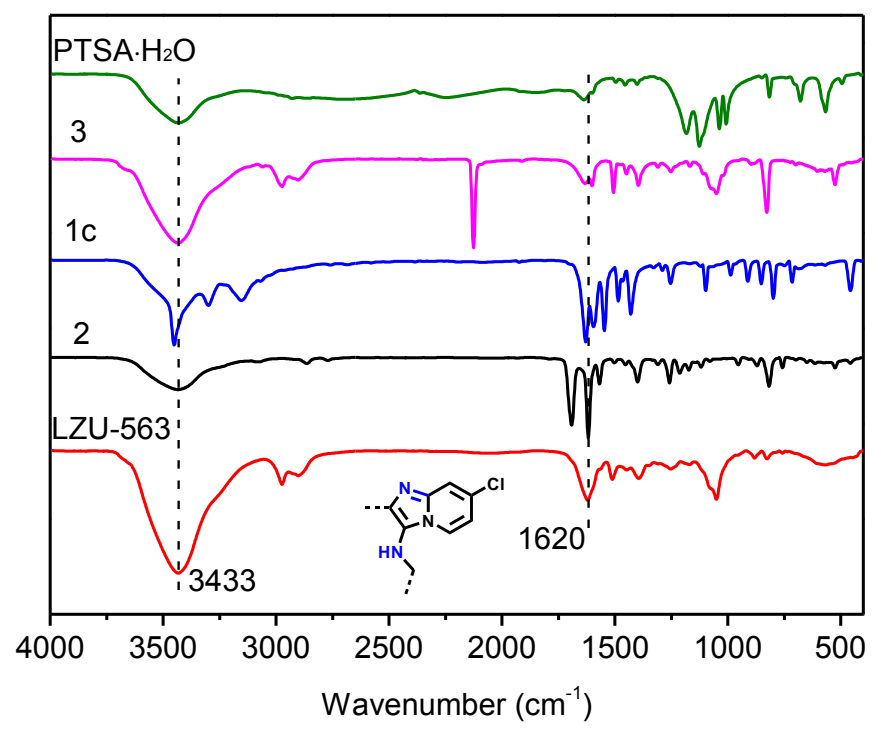

Figure S32. FT-IR spectrum of LZU-563 (red), monomer 2 (black), monomer 1c (blue), monomer 3 (purple), and PTSA $\cdot \mathrm{H}_{2} \mathrm{O}$ (as the catalytst, green). The FT-IR spectrum of LZU-563 (red) shows stretches at $1620 \mathrm{~cm}^{-1}$, indicating the formation of pyrimidazole ring.

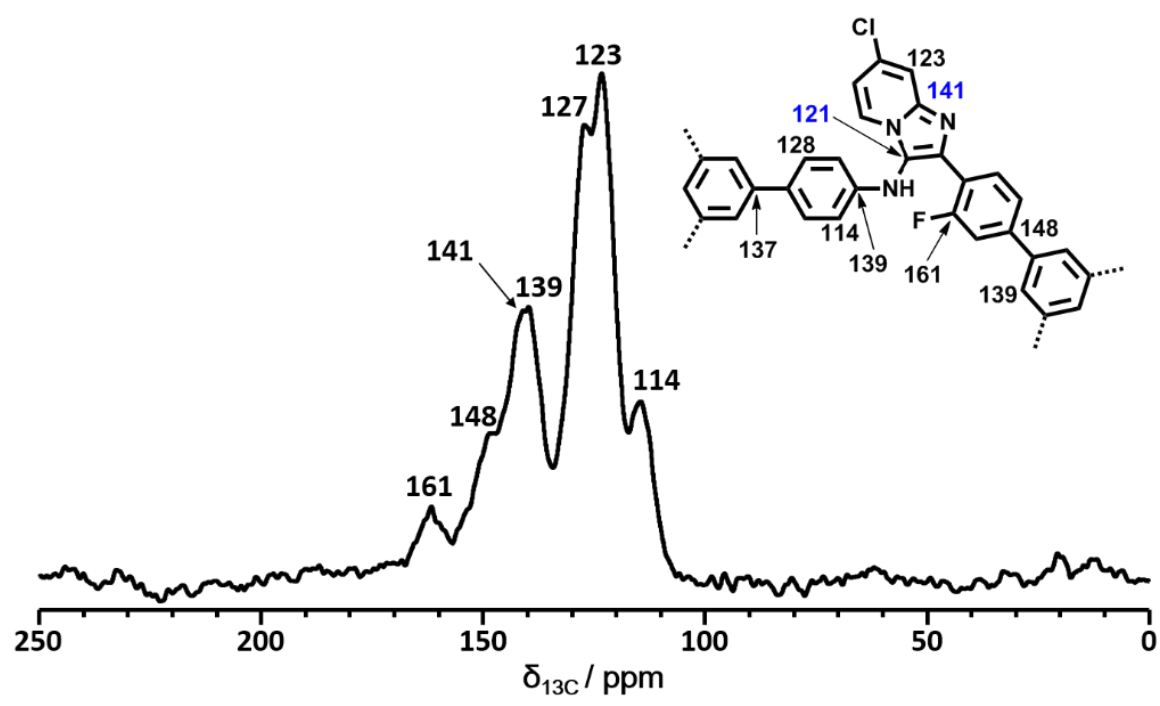

Figure S33. ${ }^{13} \mathrm{C} \mathrm{CP} / \mathrm{MAS} \mathrm{NMR}$ spectrum of LZU-563. The assignments of ${ }^{13} \mathrm{C}$ chemical shifts were indicated in the chemical structure. 


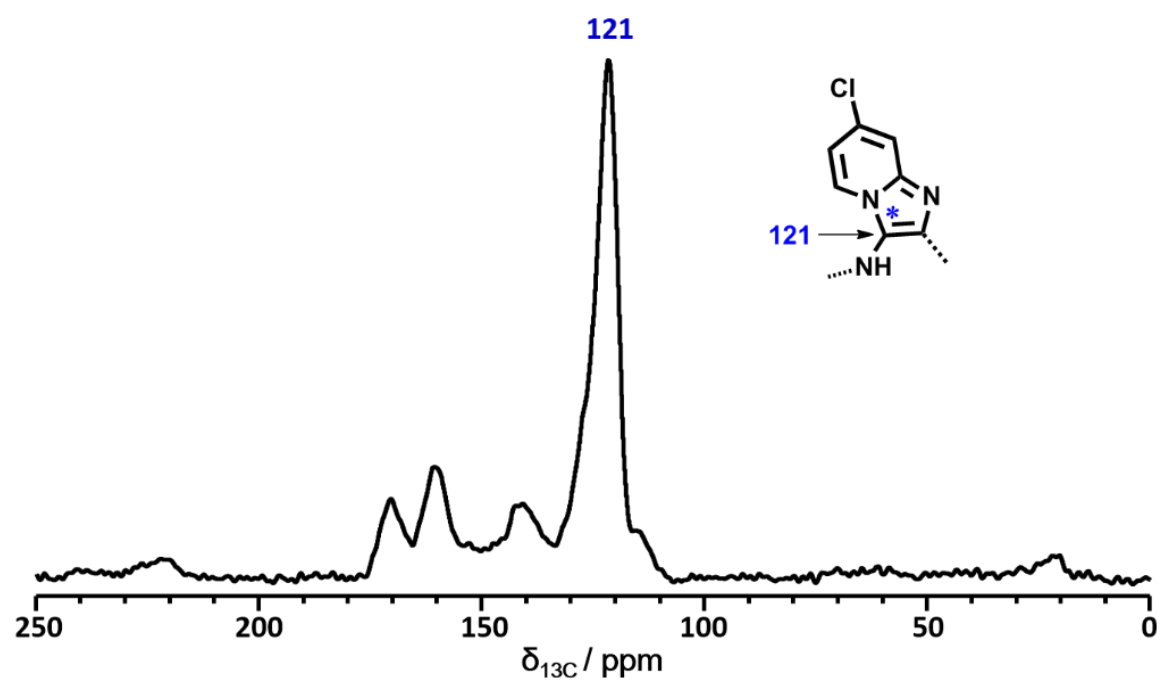

Figure S34. ${ }^{13} \mathrm{C}$ CP/MAS NMR spectra of ${ }^{13} \mathrm{C}$-labeled LZU-563. The ${ }^{13} \mathrm{C}$-labeled LZU-563 was made by ${ }^{13} \mathrm{C}$ labeled $1,3,5$-tris(4-isocyanophenyl) benzene $\left(-\mathrm{N} \equiv{ }^{13} \mathrm{C}\right)$. The presence of the peak at $121 \mathrm{ppm}$ indicates the formation of pyrimidazole ring with the ${ }^{13} \mathrm{C}$-labeled atom as *.

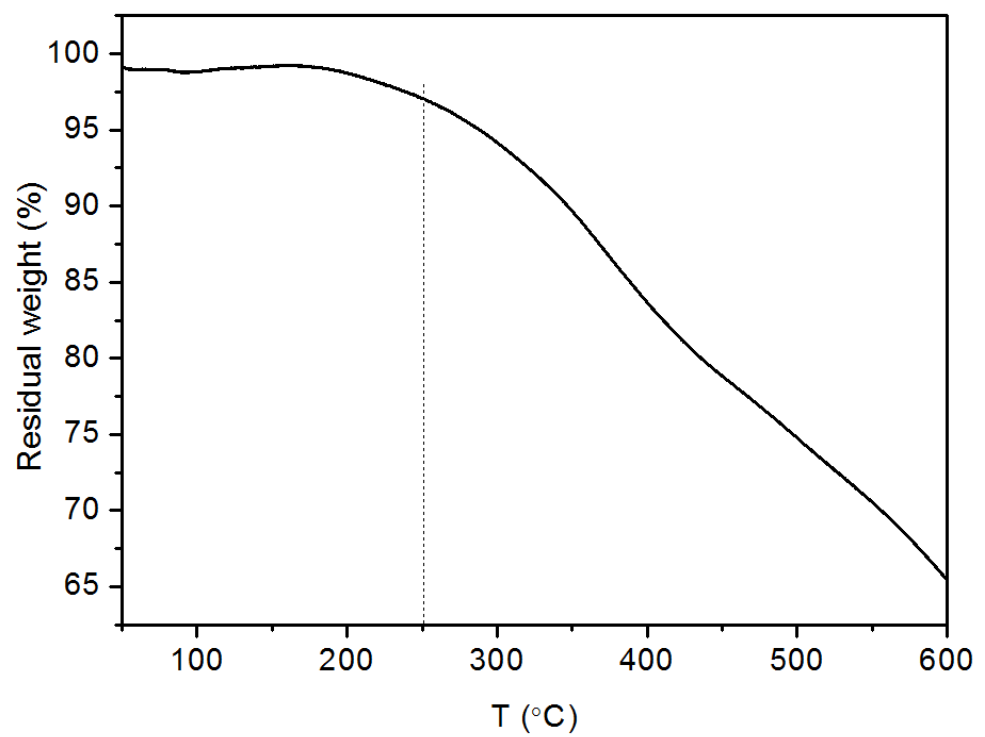

Figure S35. TGA data of LZU-563, indicating that LZU-563 is thermally stable up to $250^{\circ} \mathrm{C}$. 

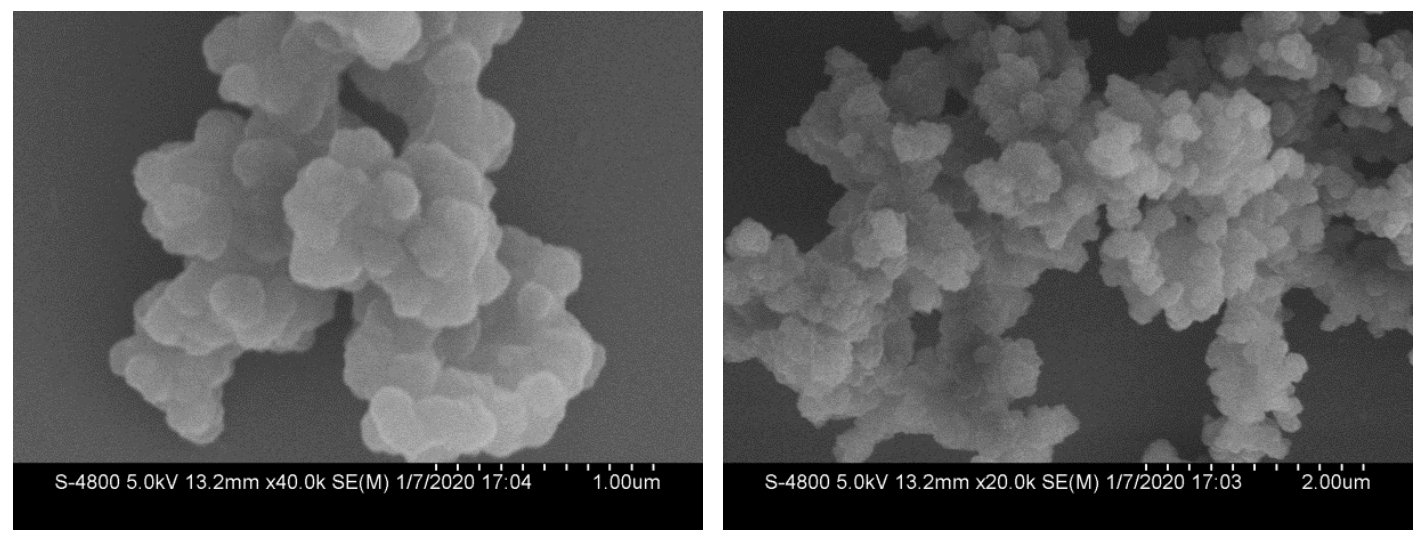

Figure S36. SEM images of LZU-563.
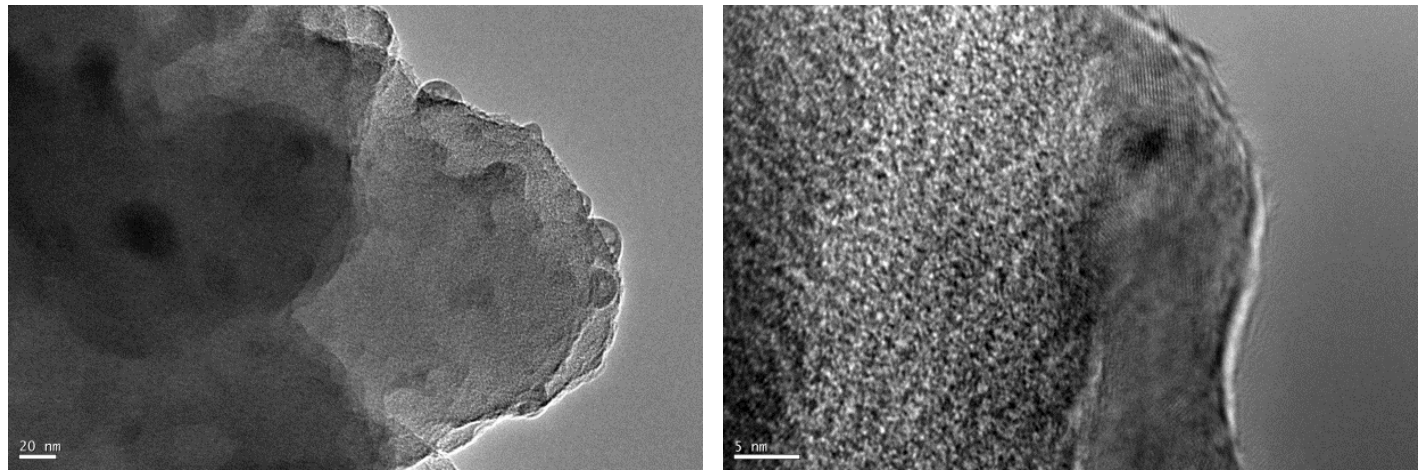

Figure S37. TEM images of LZU-563. 
The structural modeling of LZU-563 is similar to that of LZU-561. The Pawley refined lattice parameters were determined as: $a=b=26.807( \pm 0.293) \AA$ and $c=$ 4.026 ( \pm 0.046$) \AA$. $R \mathrm{wp}$ and $R \mathrm{p}$ values converged to $7.29 \%$ and $5.58 \%$, respectively. Comparison of the observed and the simulated PXRD patterns (Figure S38) suggested that the preferable structure of LZU-563 is the eclipsed arrangement.

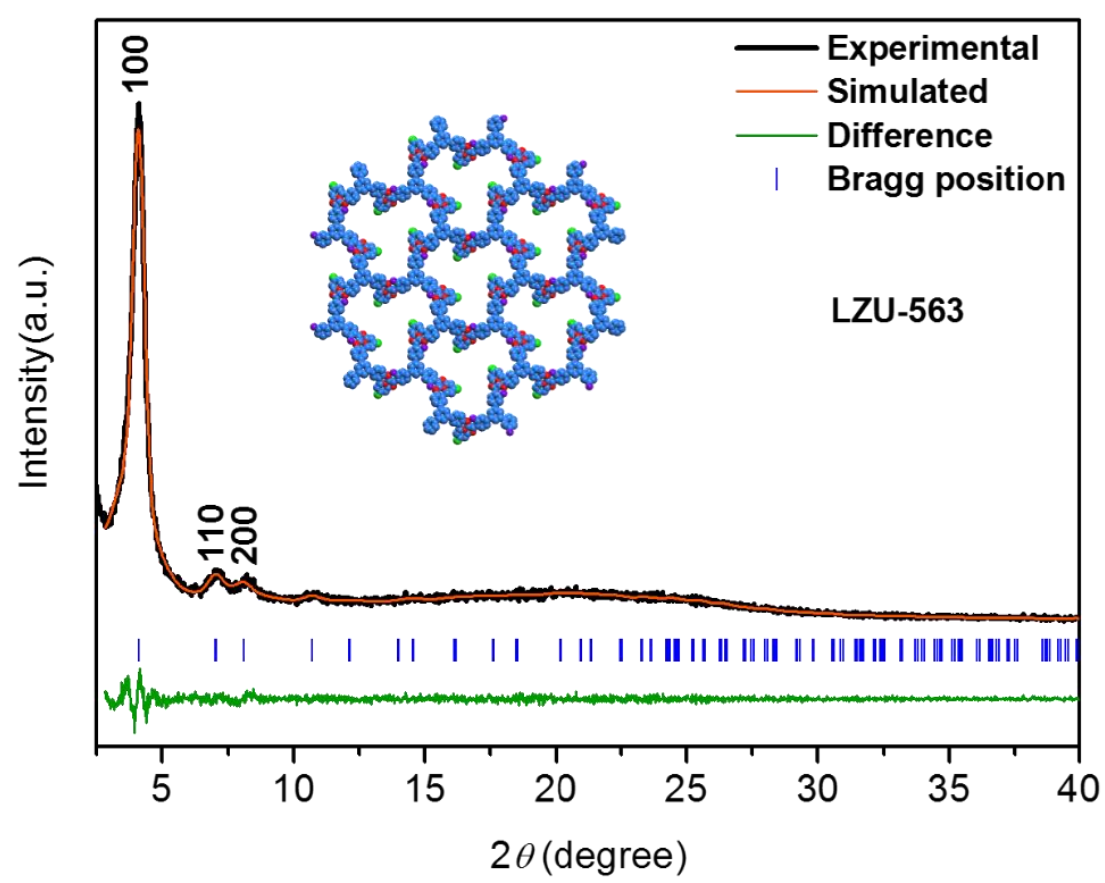

Figure S38. Indexed PXRD pattern and Pawley-refined profile of LZU-563. Inset: Structure of LZU-563 simulated with the eclipsed stacking model. C: blue, N: red, F: purple, $\mathrm{Cl}$ : green and $\mathrm{H}$ atoms are omitted for clarity. 


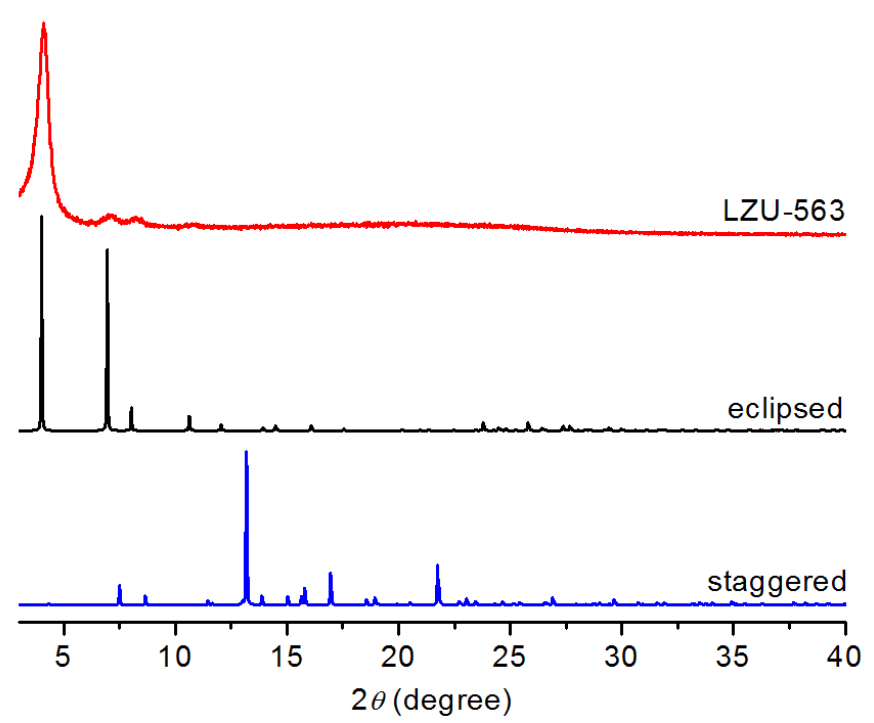

Figure S39. PXRD patterns of LZU-563: observed (red) and calculated with the eclipsed (black)/staggered (blue) stacking models. Comparison of the observed and the simulated PXRD patterns suggests that the preferable structure of LZU-563 is the eclipsed arrangement.

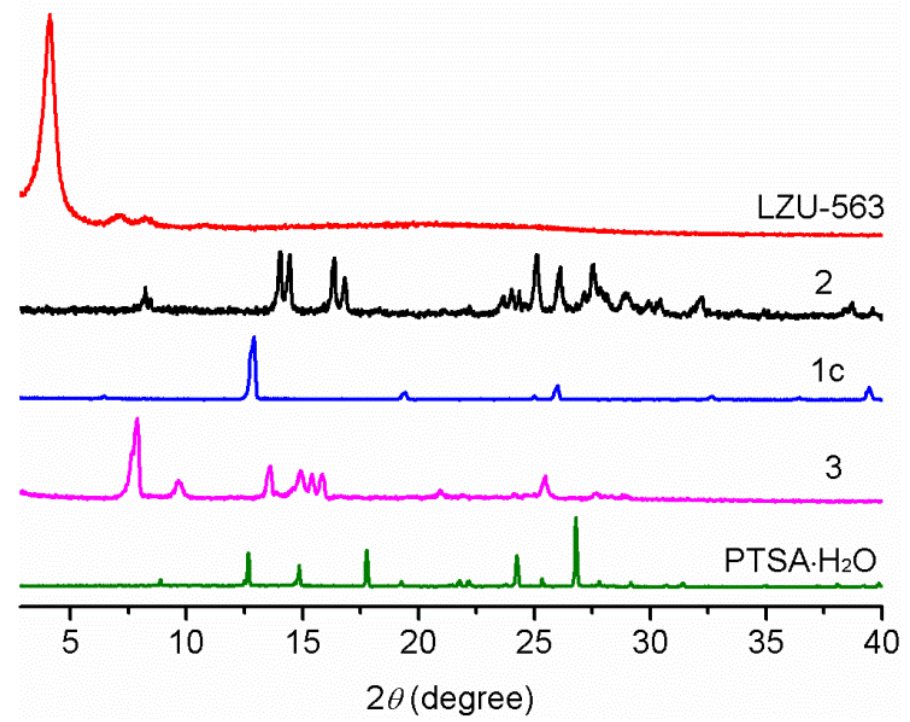

Figure S40. PXRD patterns of LZU-563 (red), monomer 2 (black), monomer 1c (blue), monomer 3 (purple), and PTSA $\cdot \mathrm{H}_{2} \mathrm{O}$ (as the catalyst, green). No diffraction peaks from 1c, 2, 3, and PTSA. $\mathrm{H}_{2} \mathrm{O}$ could be observed in the PXRD pattern of LZU-563, indicating the formation of new crystalline structure. 
Table S3. Fractional atomic coordinates for the unit cell of LZU-563.

\begin{tabular}{|c|c|c|c||c|c|c|c|}
\hline \multicolumn{7}{|c|}{ Space group: $P 3$} \\
\hline Atom & $\mathbf{X}(\mathbf{\AA})$ & $\mathbf{Y}(\mathbf{\AA})$ & $\mathbf{Z}(\mathbf{\AA})$ & Atom & $\mathbf{X}(\AA)$ & Y $(\AA)$ & $\mathbf{Z}(\mathbf{A})$ \\
\hline C1 & 0.94494 & -0.05657 & 0.41376 & C22 & 0.37982 & -0.27289 & 0.75599 \\
\hline C2 & 1.00147 & -0.05407 & 0.41959 & F23 & 0.71785 & -0.18157 & 0.53848 \\
\hline C3 & 0.88672 & -0.11598 & 0.3717 & C24 & 0.54939 & -0.38649 & 0.1738 \\
\hline C4 & 0.8308 & -0.12159 & 0.49333 & C25 & 0.51662 & -0.44678 & 0.02641 \\
\hline C5 & 0.77432 & -0.17634 & 0.42325 & C26 & 0.54914 & -0.47229 & -0.14669 \\
\hline C6 & 0.77409 & -0.22569 & 0.23915 & C27 & 0.61443 & -0.43752 & -0.17242 \\
\hline C7 & 0.83055 & -0.22046 & 0.12392 & H28 & 1.00261 & -0.09575 & 0.41976 \\
\hline C8 & 0.88703 & -0.1657 & 0.194 & H29 & 0.82946 & -0.08605 & 0.64214 \\
\hline C9 & 0.71761 & -0.28044 & 0.16907 & H30 & 0.83044 & -0.25965 & -0.02248 \\
\hline C10 & 0.65808 & -0.29221 & 0.26715 & H31 & 0.93168 & -0.16152 & 0.10305 \\
\hline N11 & 0.61428 & -0.3521 & 0.14759 & H32 & 0.68226 & -0.20549 & 0.53394 \\
\hline C12 & 0.6468 & -0.37761 & -0.02552 & H33 & 0.60778 & -0.1808 & 0.80412 \\
\hline N13 & 0.71069 & -0.33349 & -0.01294 & H34 & 0.50007 & -0.2153 & 0.95213 \\
\hline N14 & 0.64479 & -0.25083 & 0.45374 & H35 & 0.43375 & -0.39179 & 0.43003 \\
\hline C15 & 0.58258 & -0.26875 & 0.53517 & H36 & 0.41564 & -0.22631 & 0.75612 \\
\hline C16 & 0.56929 & -0.22737 & 0.72176 & C137 & 0.52478 & -0.51736 & -0.25928 \\
\hline C17 & 0.50852 & -0.24626 & 0.80039 & H38 & 0.54528 & 0.64021 & 0.28353 \\
\hline C18 & 0.45963 & -0.30385 & 0.69317 & H39 & 0.52375 & 0.63381 & 0.31098 \\
\hline C19 & 0.47224 & -0.34523 & 0.5124 & H40 & 0.46503 & 0.52582 & 0.04704 \\
\hline C20 & 0.53445 & -0.3273 & 0.43097 & H41 & 0.64022 & 0.54232 & -0.3094 \\
\hline C21 & 0.3949 & -0.31912 & 0.74819 & & & & \\
\hline
\end{tabular}




\section{G. Synthesis and Characterization of LZU-564}

Synthesis of LZU-564
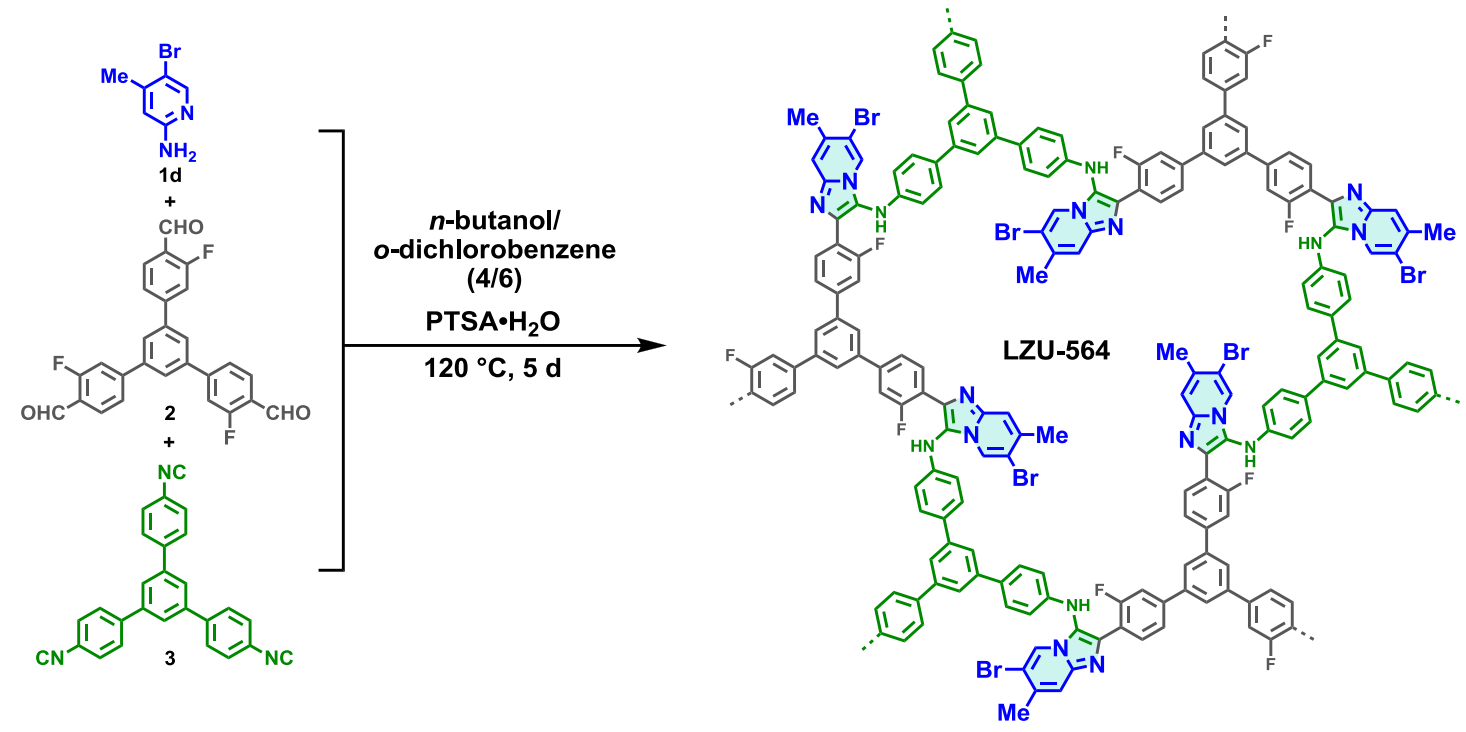

The synthetic procedure of LZU-564 was similar to that of LZU-561. Condensation of 2-amino-5-bromo-4-methylpyridine 1d (22 mg, $0.117 \mathrm{mmol}$ ), 1,3,5-tris(3-fluoro-4-formylphenyl)benzene 2 (11.3 $\mathrm{mg}, 0.025 \mathrm{mmol})$, 1,3,5-tris (4-isocyanophenyl) benzene $3(9.7 \mathrm{mg}, 0.025 \mathrm{mmol})$ and $p$-toluenesulfonic acid monohydrate $(3.5 \mathrm{mg}, 0.018 \mathrm{mmol})$ yielded LZU-564 as a yellow powder (24.6 mg, 74\% yield). Anal. Cald for $\left(\mathrm{C}_{24} \mathrm{H}_{15} \mathrm{~N}_{3} \mathrm{FBr}\right)_{\mathrm{n}}$ : C 64.88; H 3.40; N 9.46, found: C 68.15; H 3.79; N 6.69. Characterization of LZU-564 was presented in the main text and in this SI.

The synthesis of ${ }^{13} \mathrm{C}$-labeled LZU-564 was similar to that of LZU-564. Condensation of 2-amino-5-bromo-4-methylpyridine 1d, 1,3,5-tris(3-fluoro-4-formyl phenyl)benzene 2, and ${ }^{13} \mathrm{C}$-labeled 1,3,5-tris(4-isocyanophenyl) benzene $\mathbf{3}\left(-\mathrm{N} \equiv{ }^{13} \mathrm{C}\right)$ yielded ${ }^{13}$ C-labeled LZU-564. 
Characterization of $L Z U-564$

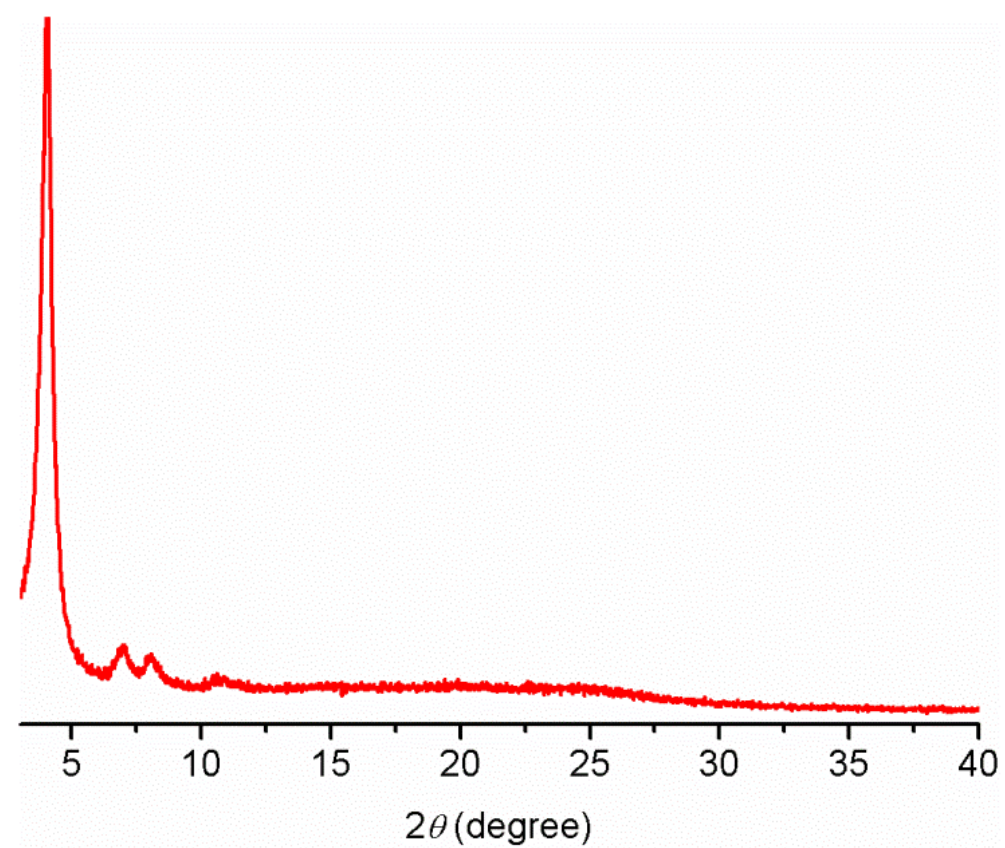

Figure S41. PXRD pattern of LZU-564 (n-butanol/o-dichlorobenzene (4/6), $120{ }^{\circ} \mathrm{C}, 5$ days).

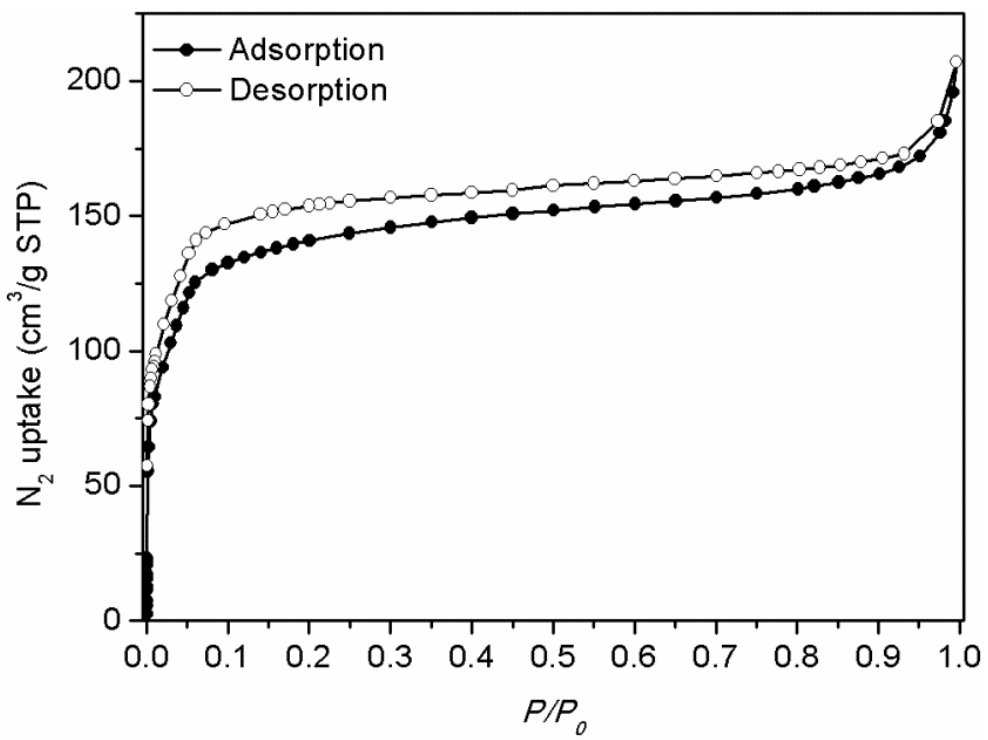

Figure S42. $\mathrm{N}_{2}$ adsorption and desorption isotherms of LZU-564. 


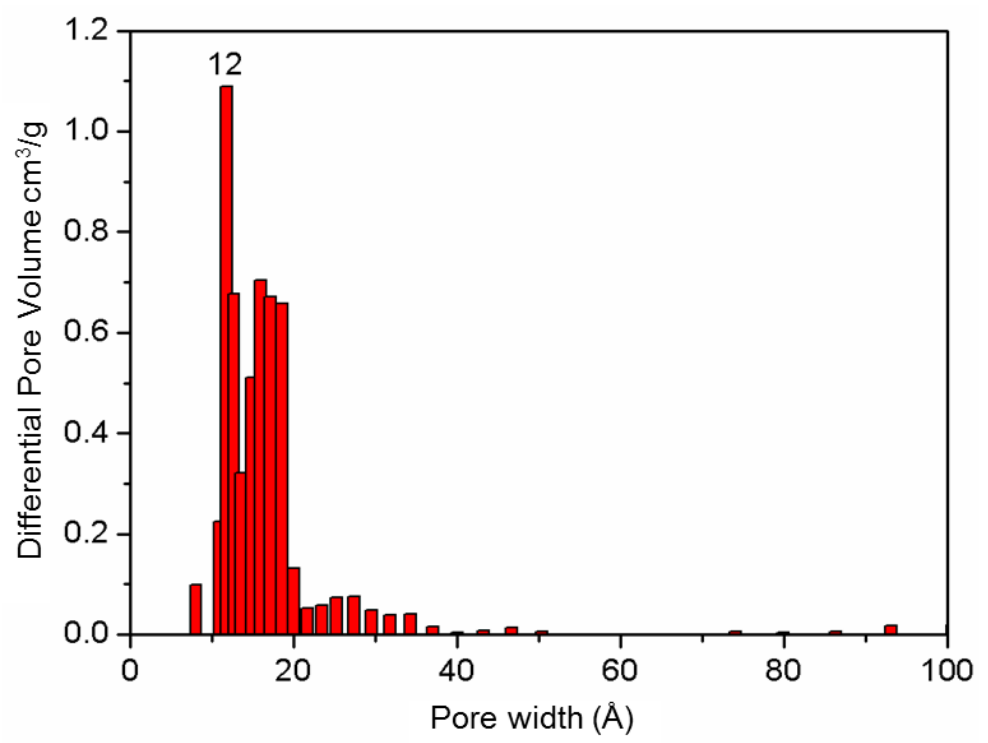

Figure S43. Pore size distribution of LZU-564 calculated by NLDFT (slit pores model).

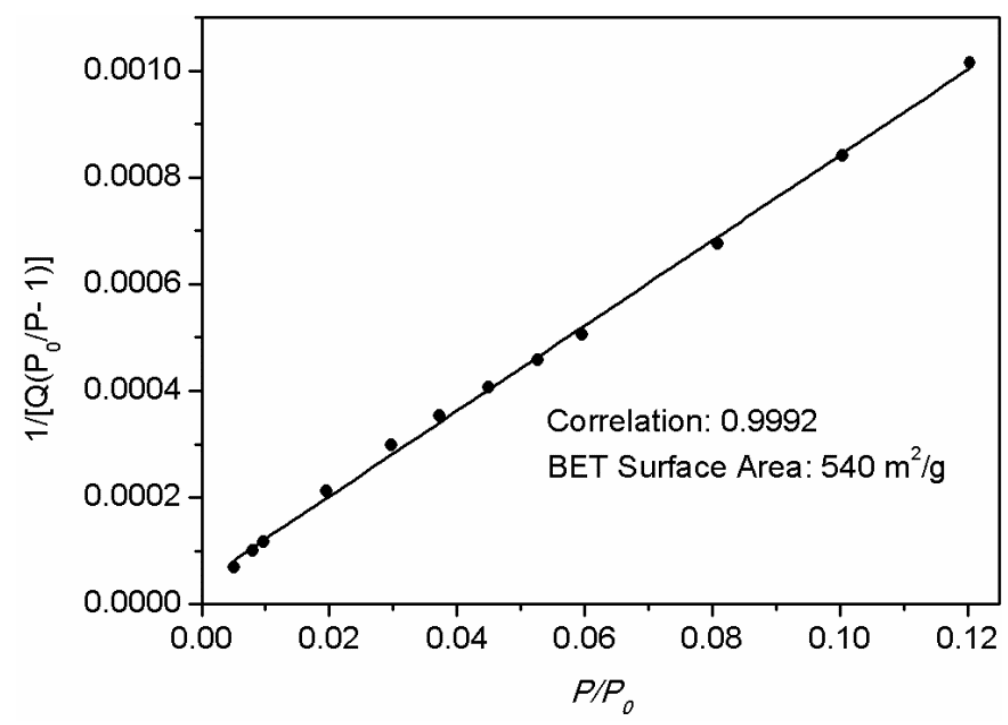

Figure S44. BET surface area plot for LZU-564 calculated from the adsorption isotherm. 


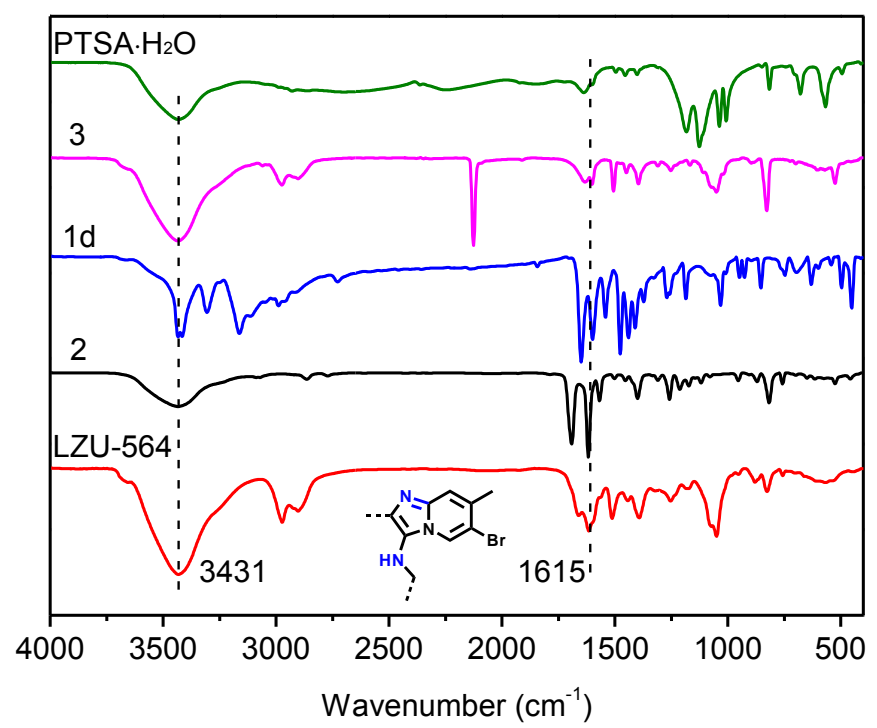

Figure S45. FT-IR spectra of the LZU-564 (red), the monomer 2 (black), the monomer 1d (blune), the monomer 3 (purple), and PTSA $\cdot \mathrm{H}_{2} \mathrm{O}$ (green). The FT-IR spectrum of LZU-564 (red) shows stretches at $1615 \mathrm{~cm}^{-1}$, indicating the formation of the pyrimidazole ring.

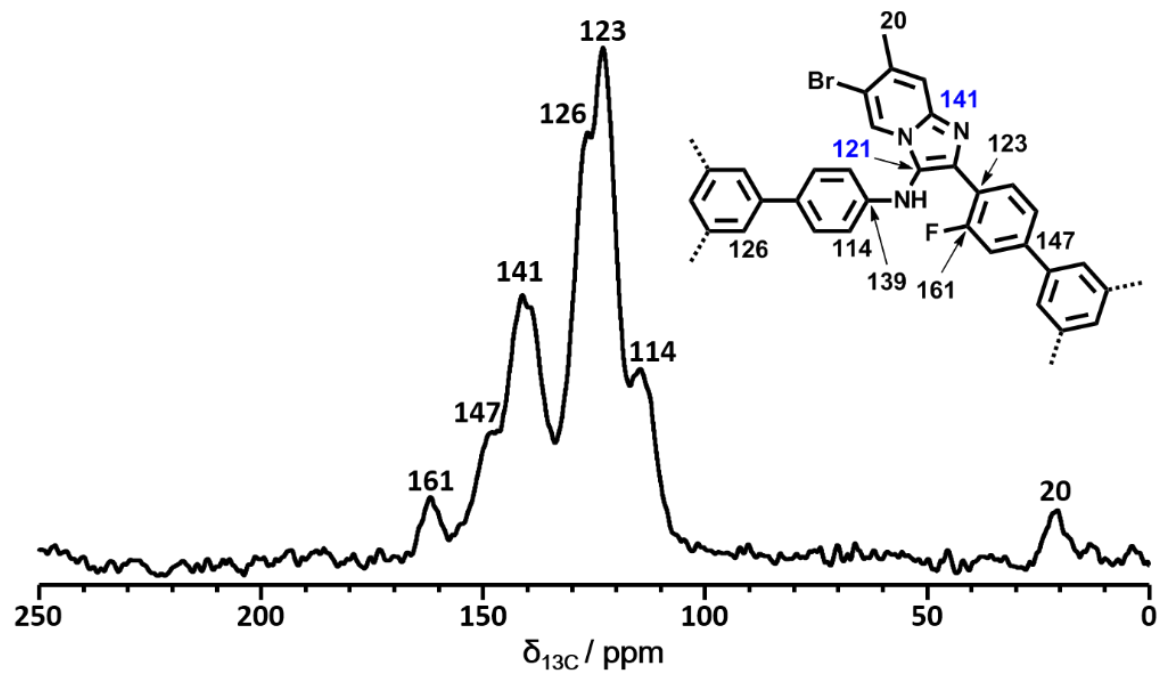

Figure S46. ${ }^{13} \mathrm{C}$ CP/MAS NMR spectra of LZU-564. The assignments of ${ }^{13} \mathrm{C}$ chemical shifts of LZU-564 were indicated in the chemical structure. 


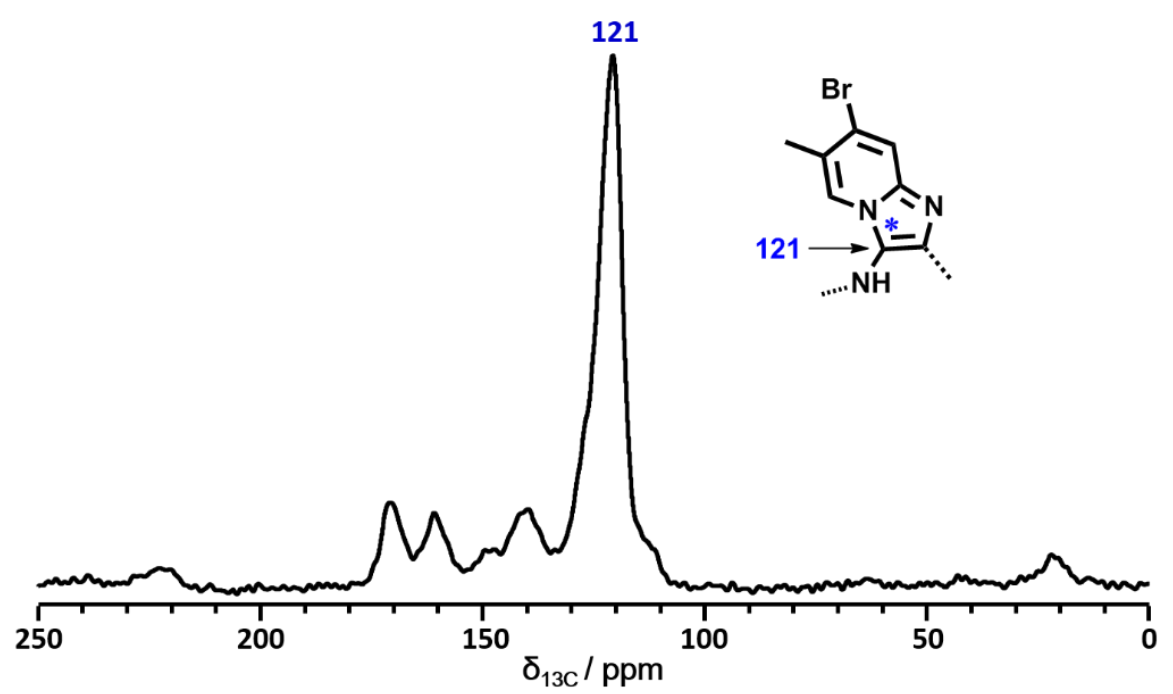

Figure S47. ${ }^{13} \mathrm{C}$ CP/MAS NMR spectra of ${ }^{13} \mathrm{C}$-labeled LZU-564. The ${ }^{13} \mathrm{C}$-labeled LZU-564 was made by ${ }^{13} \mathrm{C}$ labeled $1,3,5$-tris(4-isocyanophenyl) benzene $\left(-\mathrm{N} \equiv{ }^{13} \mathrm{C}\right)$. The presence of the peak at $121 \mathrm{ppm}$ indicates the formation of pyrimidazole ring with the ${ }^{13} \mathrm{C}$-labeled atom as *.

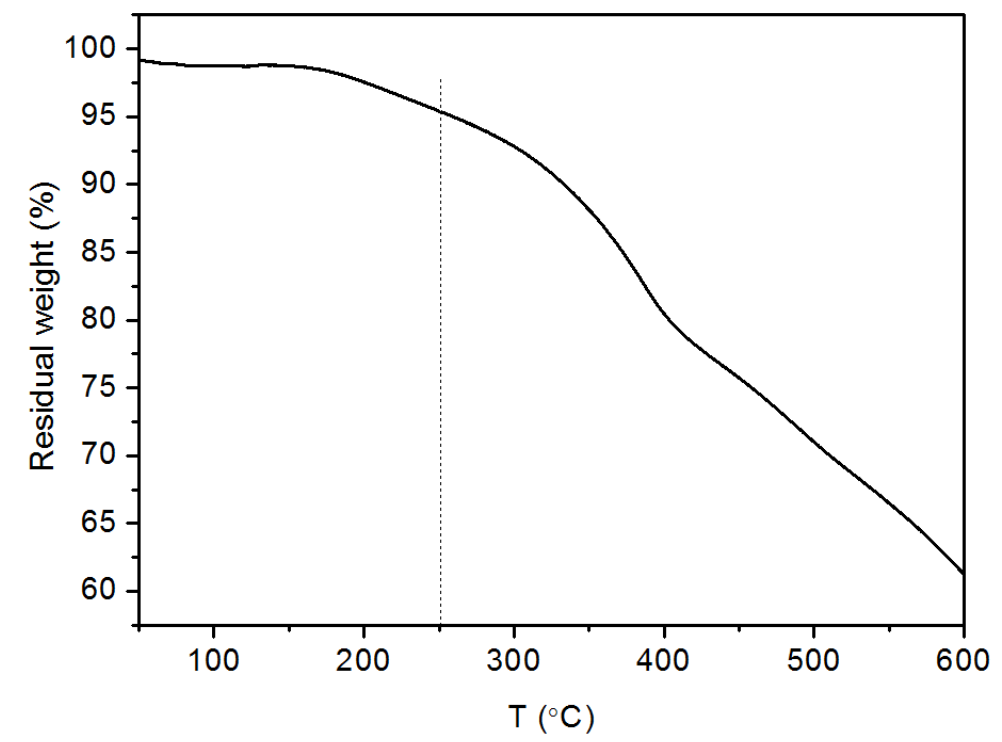

Figure S48. TGA data of LZU-564, indicating that LZU-564 is thermally stable up to $250^{\circ} \mathrm{C}$. 

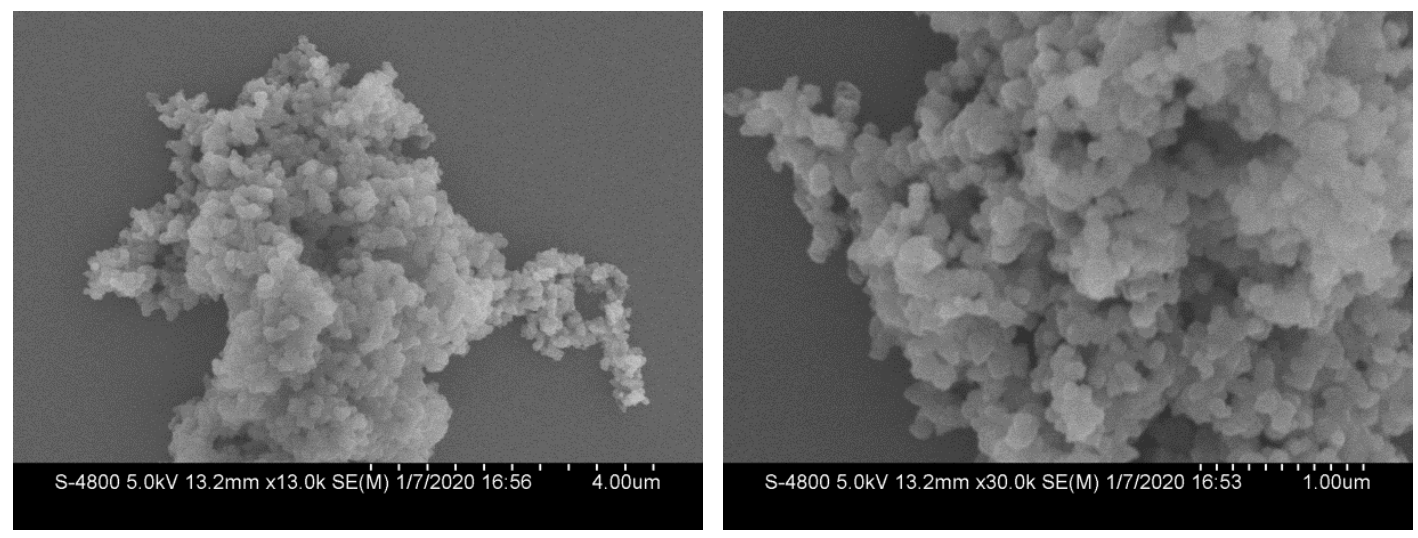

Figure S49. SEM images of LZU-564.
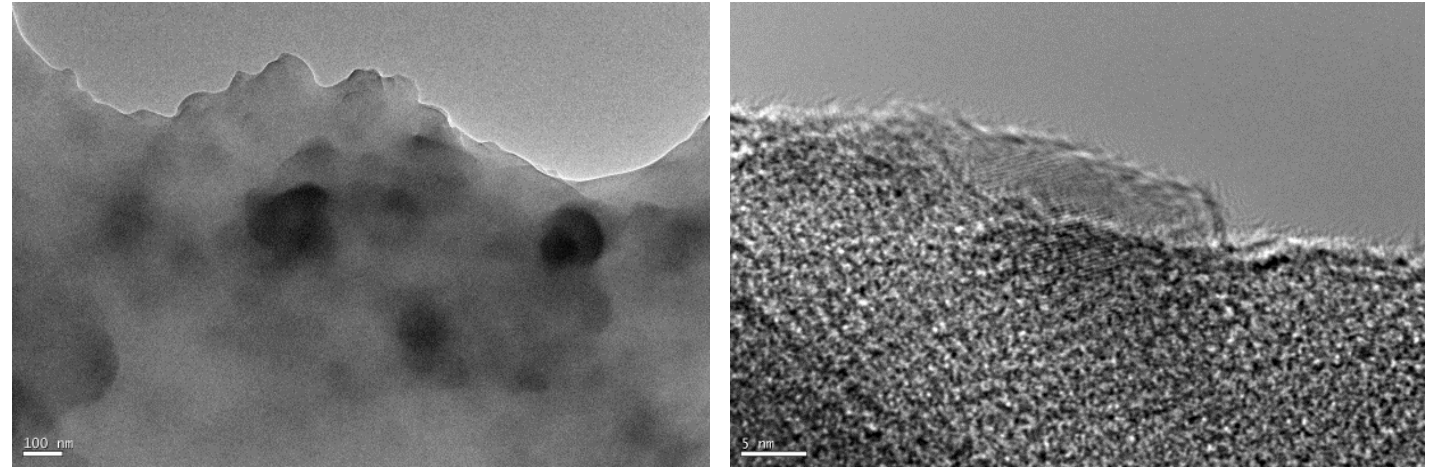

Figure S50. TEM images of LZU-564. 
The structural modeling of LZU-564 is similar to that of LZU-561. The Pawley refined lattice parameters were determined as: $a=b=25.760( \pm 0.165) \AA$ and $c=$ 3.878 ( \pm 0.025$) \AA$ A. $R \mathrm{wp}$ and $R \mathrm{p}$ values converged to $6.97 \%$ and $5.35 \%$, respectively. Comparison of the observed and the simulated PXRD patterns (Figure S51) suggests that the preferable structure of LZU-564 is the eclipsed arrangement.

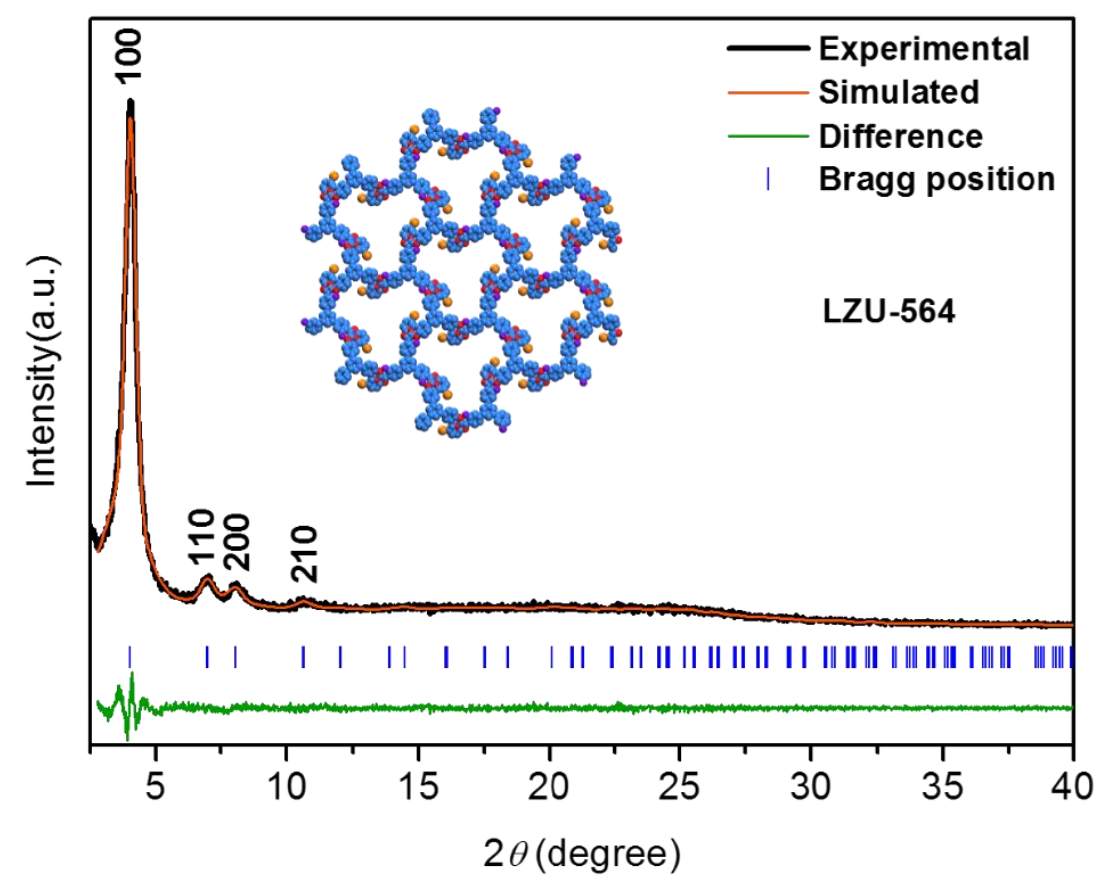

Figure S51. Indexed PXRD pattern and Pawley-refined profile of LZU-564. Inset: Structure of LZU-564 simulated with the eclipsed stacking model. C: blue, N: red, F: purple, Br: orange and $\mathrm{H}$ atoms are omitted for clarity. 


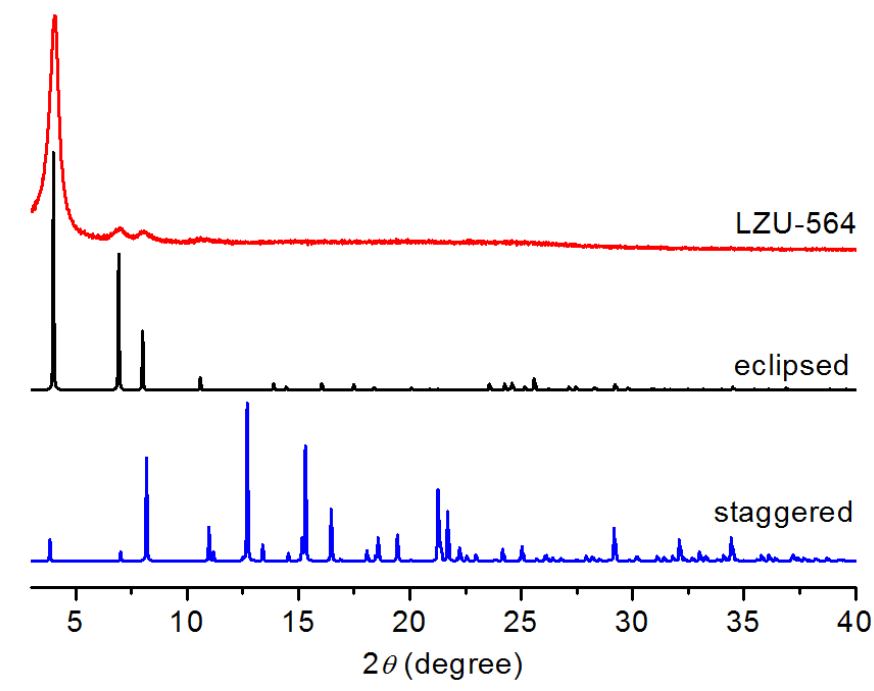

Figure S52. PXRD patterns of LZU-564: observed (red) and calculated with the eclipsed (black)/staggered (blue) stacking models. Comparison of the observed and the simulated PXRD patterns suggests that the preferable structure of LZU-564 is the eclipsed arrangement.

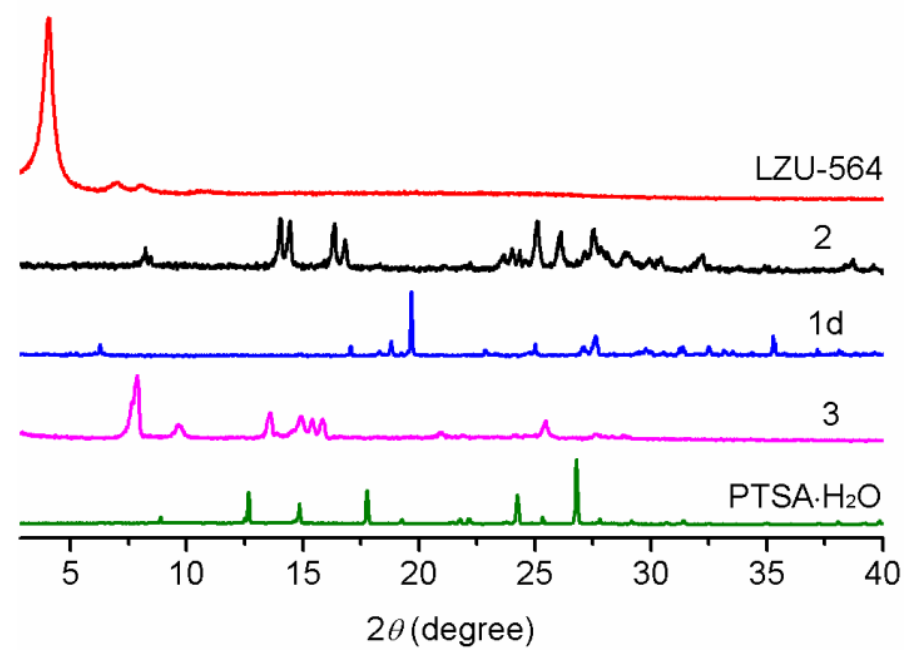

Figure S53. PXRD patterns of LZU-564 (red), the monomer 2 (black), the monomer 1d (blue), the monomer 3 (purple) and PTSA $\cdot \mathrm{H}_{2} \mathrm{O}$ (as the catalyst, green). No diffraction peaks from 1d, 2, 3, and PTSA $\cdot \mathrm{H}_{2} \mathrm{O}$ could be observed in the PXRD pattern of LZU-564, indicating the formation of new crystalline structure. 
Table S4. Fractional atomic coordinates for the unit cell of LZU-564.

\begin{tabular}{|c|c|c|c||c|c|c|c|}
\hline \multicolumn{7}{|c|}{ Space group: $P 3$} \\
\hline Atom & $\mathbf{X}(\mathbf{\AA})$ & $\mathbf{Y}(\mathbf{\AA})$ & $\mathbf{Z}(\mathbf{\AA})$ & Atom & $\mathbf{X}(\AA)$ & Y $(\AA)$ & $\mathbf{Z}(\mathbf{A})$ \\
\hline C1 & 0.94522 & -0.05672 & 0.45207 & F23 & 0.71803 & -0.18143 & 0.5363 \\
\hline C2 & 1.00189 & -0.05366 & 0.45871 & C24 & 0.55209 & -0.38638 & 0.16801 \\
\hline C3 & 0.88725 & -0.11637 & 0.40753 & C25 & 0.52022 & -0.44675 & 0.02494 \\
\hline C4 & 0.83086 & -0.12173 & 0.51256 & C26 & 0.55357 & -0.47251 & -0.13151 \\
\hline C5 & 0.77494 & -0.17644 & 0.43785 & C27 & 0.61878 & -0.4379 & -0.14488 \\
\hline C6 & 0.7757 & -0.22598 & 0.26578 & H28 & 1.00332 & -0.09495 & 0.46094 \\
\hline C7 & 0.83261 & -0.22098 & 0.16733 & H29 & 0.82872 & -0.08603 & 0.65209 \\
\hline C8 & 0.88852 & -0.16628 & 0.24204 & H30 & 0.83329 & -0.26033 & 0.03051 \\
\hline C9 & 0.71979 & -0.28069 & 0.19107 & H31 & 0.93352 & -0.16228 & 0.16435 \\
\hline C10 & 0.65992 & -0.29223 & 0.273 & H32 & 0.68259 & -0.20528 & 0.52625 \\
\hline N11 & 0.61691 & -0.35215 & 0.15412 & H33 & 0.60688 & -0.18016 & 0.76655 \\
\hline C12 & 0.65026 & -0.37791 & -0.00232 & H34 & 0.49872 & -0.21426 & 0.88835 \\
\hline N13 & 0.71388 & -0.33391 & 0.01986 & H35 & 0.43544 & -0.39117 & 0.38855 \\
\hline N14 & 0.64566 & -0.25062 & 0.44519 & H36 & 0.41486 & -0.22647 & 0.69342 \\
\hline C15 & 0.58322 & -0.26833 & 0.51111 & C37 & 0.5299 & -0.51765 & -0.2408 \\
\hline C16 & 0.56896 & -0.22673 & 0.68329 & H38 & 0.5474 & 0.64045 & 0.26988 \\
\hline C17 & 0.50797 & -0.24541 & 0.74708 & H39 & 0.52579 & 0.63412 & 0.29201 \\
\hline C18 & 0.45982 & -0.30302 & 0.63844 & Br40 & 0.46869 & 0.52598 & 0.03578 \\
\hline C19 & 0.47336 & -0.3446 & 0.47181 & H41 & 0.64523 & 0.54175 & -0.26867 \\
\hline C20 & 0.5358 & -0.32689 & 0.40588 & H42 & 0.50922 & 0.44741 & -0.03099 \\
\hline C21 & 0.39489 & -0.31871 & 0.68443 & H43 & 0.55734 & 0.46627 & -0.38574 \\
\hline C22 & 0.37938 & -0.27296 & 0.69141 & H44 & 0.49516 & 0.4733 & -0.44172 \\
\hline
\end{tabular}




\section{H. Synthesis and Characterization of LZU-565}

Synthesis of LZU-565

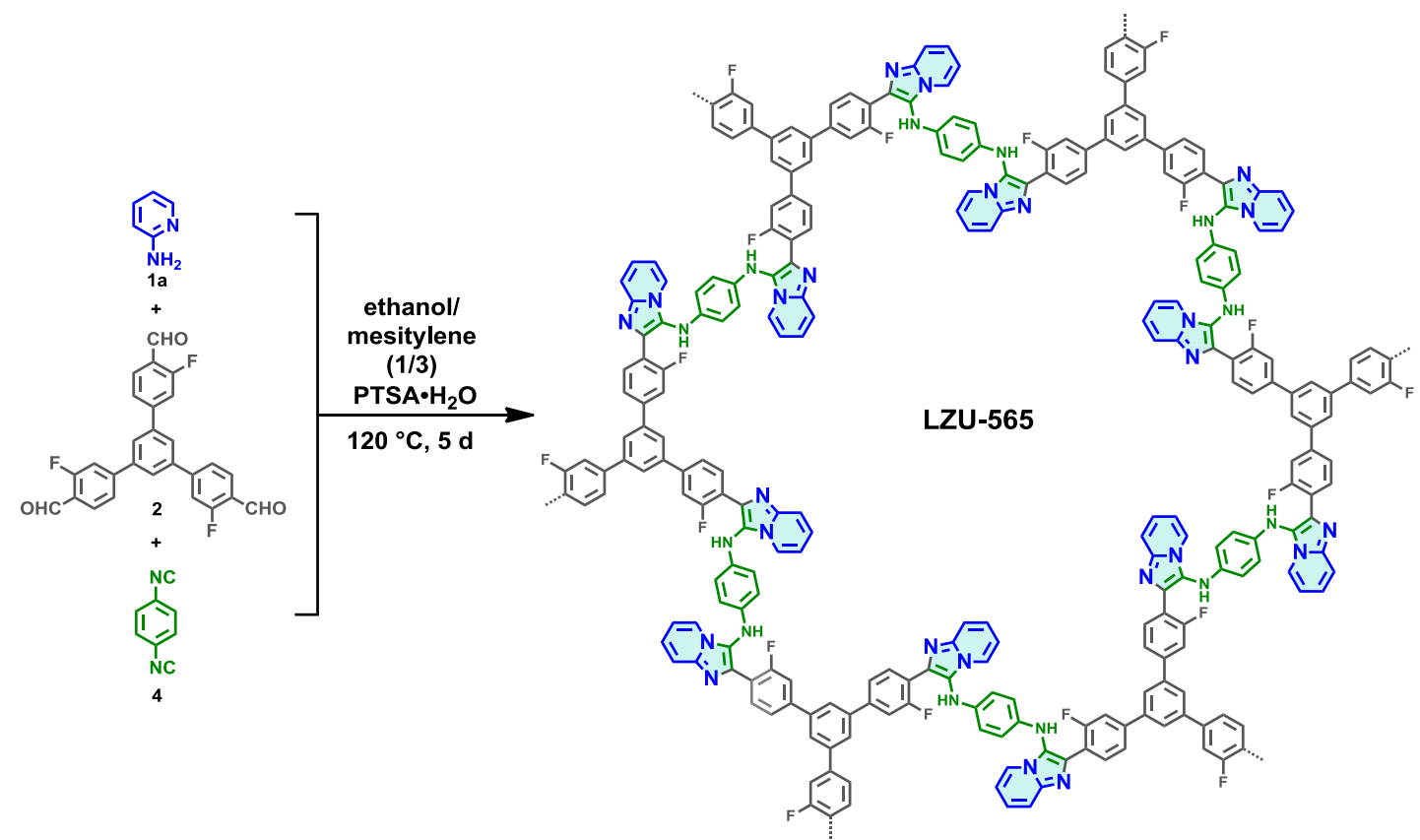

The synthetic procedure of LZU-565 was similar to that of LZU-561. Condensation of 2-amino-pyridine 1a (17.0 mg, $0.180 \mathrm{mmol})$, 1,3,5-tris (3-fluoro-4formylphenyl) benzene 2 (22.3 mg, $0.050 \mathrm{mmol})$, 1,4-diisocyanobenzene 4 (9.7 mg, $0.075 \mathrm{mmol})$ and $p$-toluenesulfonic acid monohydrate $(7.0 \mathrm{mg}, 0.037 \mathrm{mmol})$ yielded LZU-565 as a dark green powder (38.3 mg, 88\% yield). Anal. Cald for $\left(\mathrm{C}_{18} \mathrm{H}_{11} \mathrm{~N}_{3} \mathrm{~F}\right) \mathrm{n}$ : C 74.99; H 3.85; N 14.58, found: C 72.12; H 4.14; N 10.91.Characterization of LZU-565 was presented in the main text and in this SI.

The synthesis of ${ }^{13} \mathrm{C}$-labeled LZU-565 was similar to that of LZU-565. Condensation of 2-amino-pyridine 1a, 1,3,5-tris(3-fluoro-4-formyl phenyl)benzene 2, and ${ }^{13} \mathrm{C}$-labeled 1,4-diisocyanobenzene $4\left(-\mathrm{N} \equiv{ }^{13} \mathrm{C}\right)$ yielded ${ }^{13} \mathrm{C}$-labeled LZU-565. 
Characterization of $L Z U-565$

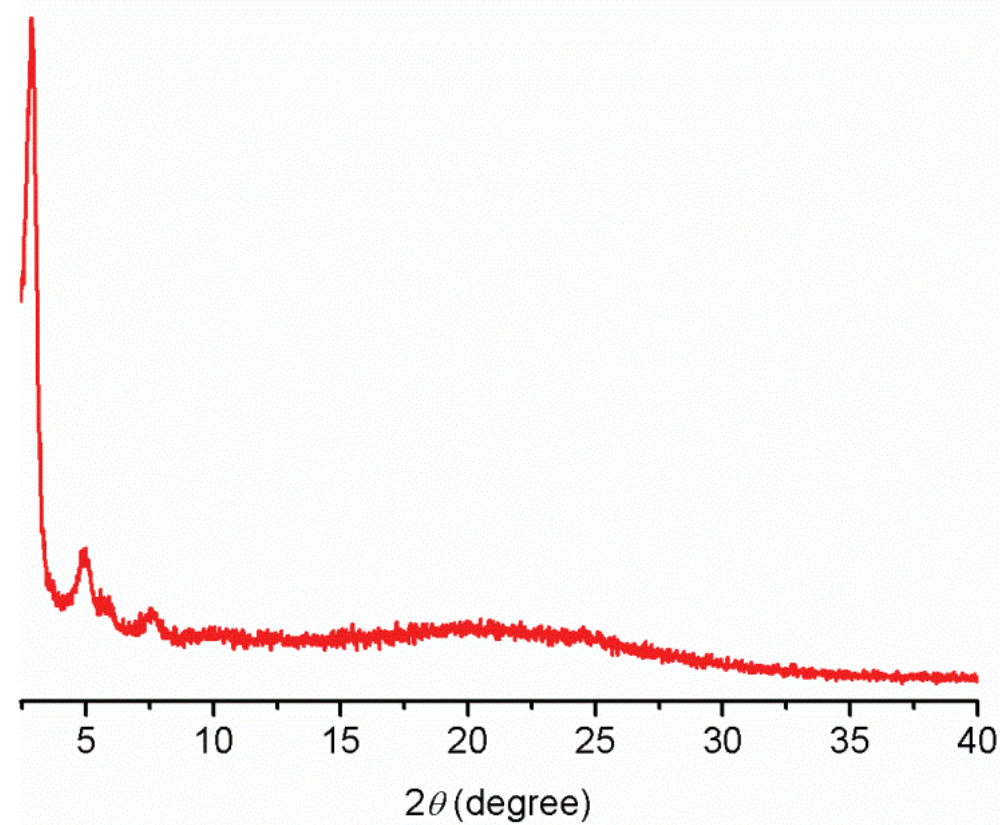

Figure S54. PXRD pattern of LZU-565 (ethanol/mesitylene (1/3), $120^{\circ} \mathrm{C}, 5$ days).

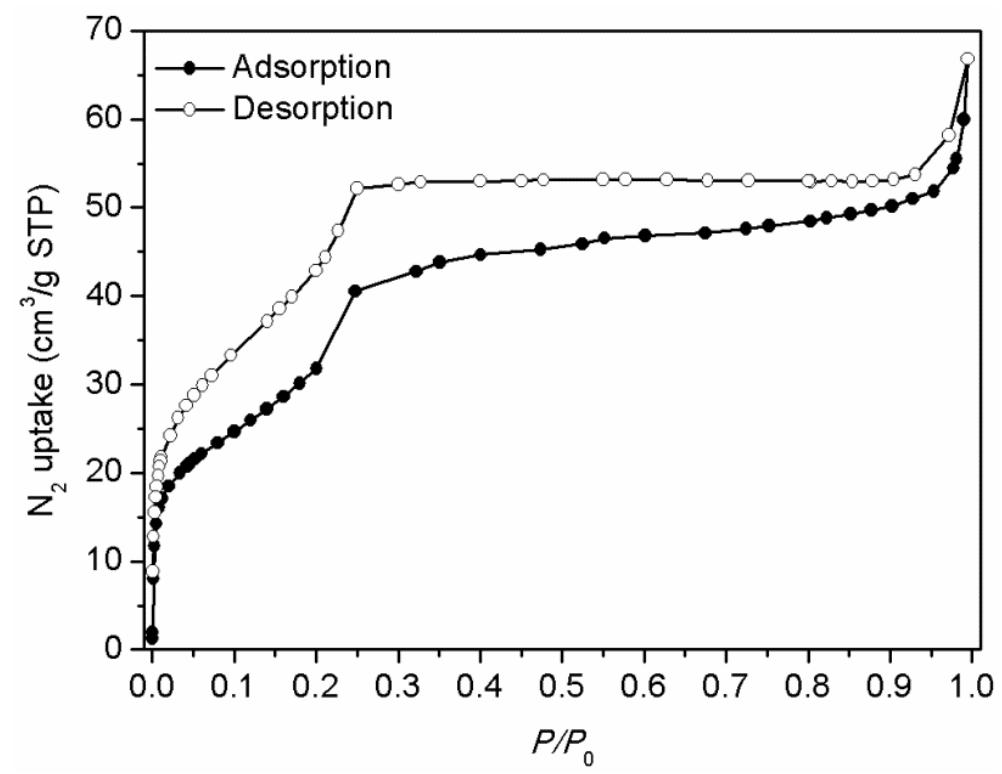

Figure S55. $\mathrm{N}_{2}$ adsorption and desorption isotherms of LZU-565. 


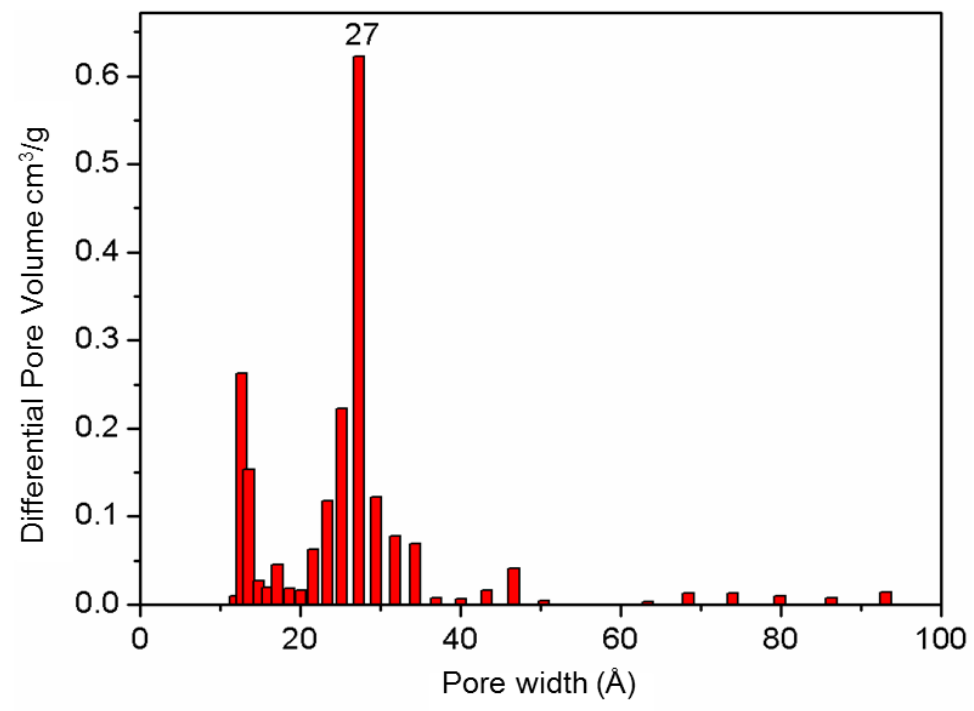

Figure S56. Pore size distribution of LZU-565 calculated by NLDFT (slit pores model).

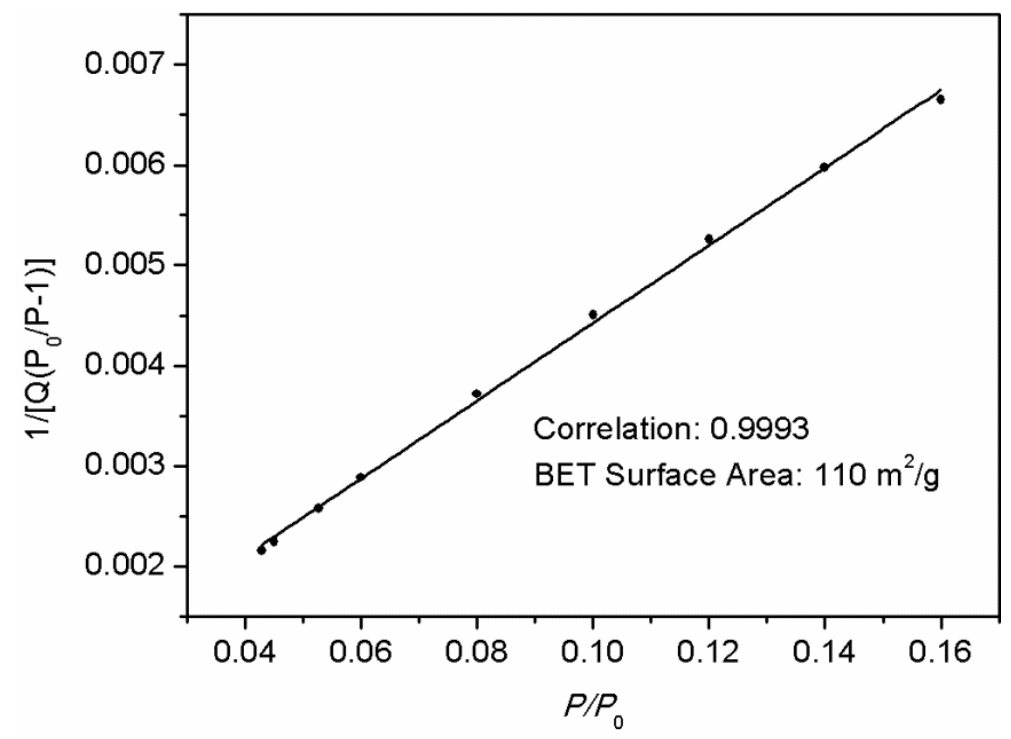

Figure S57. BET surface area plot for LZU-565 calculated from the adsorption isotherm. 


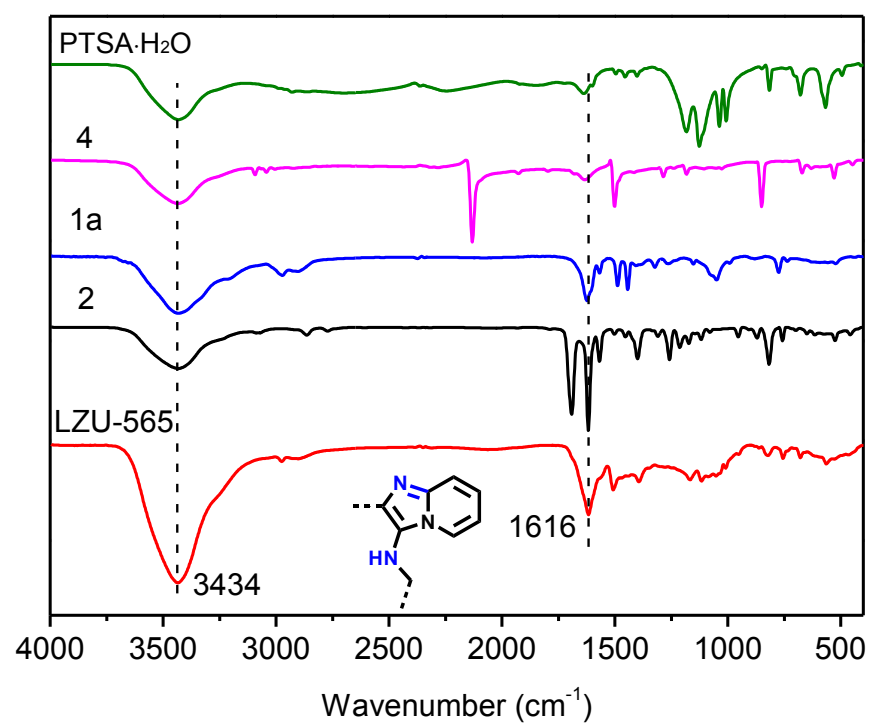

Figure S58. FT-IR spectra of LZU-565 (red), the monomer 2 (black), monomer 1a (blue), monomer 4 (purple), and PTSA $\cdot \mathrm{H}_{2} \mathrm{O}$ (as the catalyst, green). The FT-IR spectrum of LZU-565 (red) shows stretches at $1616 \mathrm{~cm}^{-1}$ indicating the formation of the pyrimodazole ring.

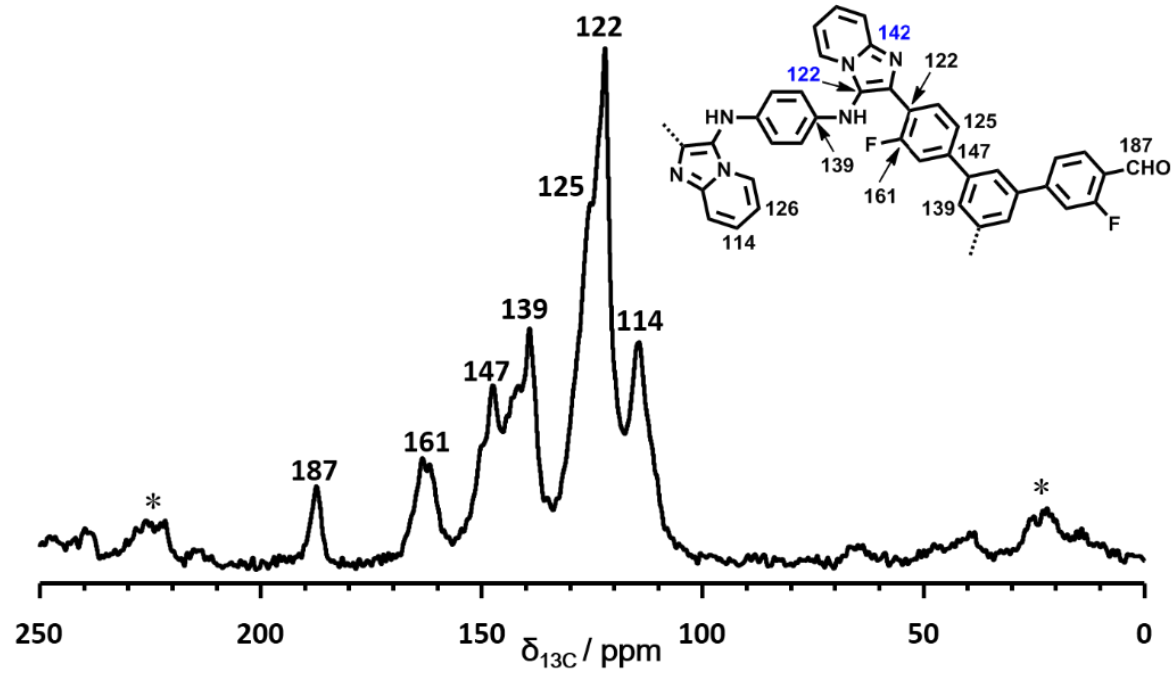

Figure S59. ${ }^{13} \mathrm{C}$ CP/MAS NMR spectra of LZU-565. The assignments of ${ }^{13} \mathrm{C}$ chemical shifts of LZU-565 were indicated in the chemical structure. 


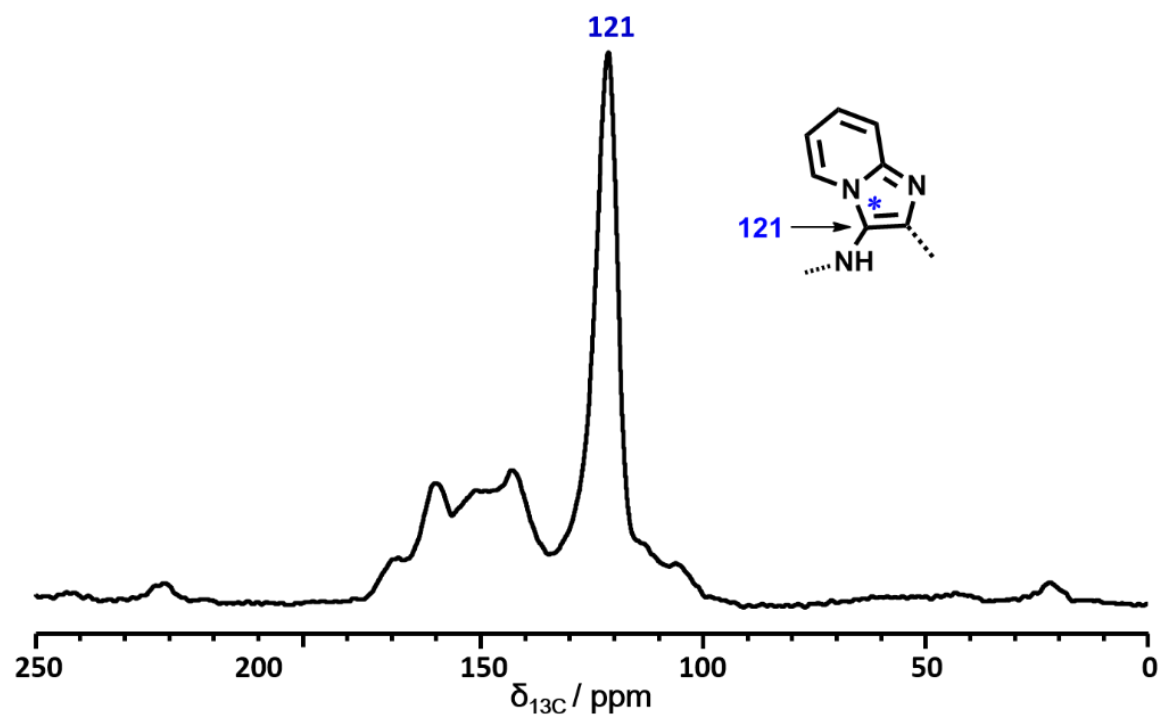

Figure S60. ${ }^{13} \mathrm{C}$ CP/MAS NMR spectra of ${ }^{13} \mathrm{C}$-labeled LZU-565. The ${ }^{13} \mathrm{C}$-labeled LZU-565 was made by ${ }^{13} \mathrm{C}$ labeled 1 ,4-diisocyanobenzene $\left(-\mathrm{N} \equiv{ }^{13} \mathrm{C}\right)$. The presence of the peak at $121 \mathrm{ppm}$ indicates the formation of pyrimidazole ring with the ${ }^{13} \mathrm{C}$-labeled atom as *.

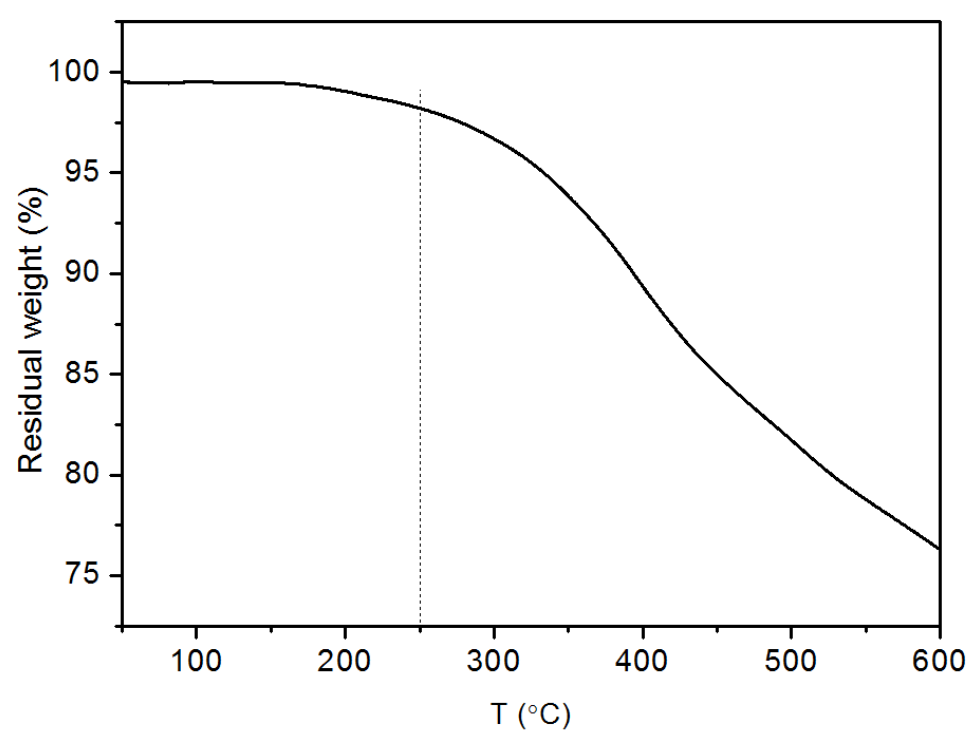

Figure S61. TGA data of LZU-565, indicating that LZU-565 is thermally stable up to $300{ }^{\circ} \mathrm{C}$. 

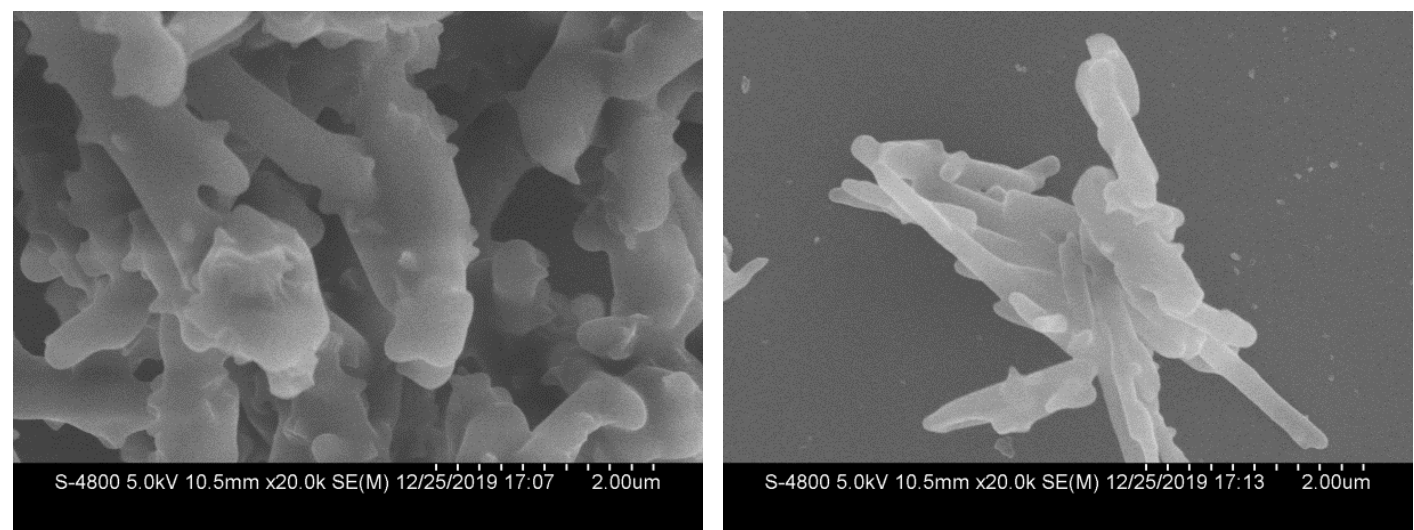

Figure S62. SEM images of LZU-565.
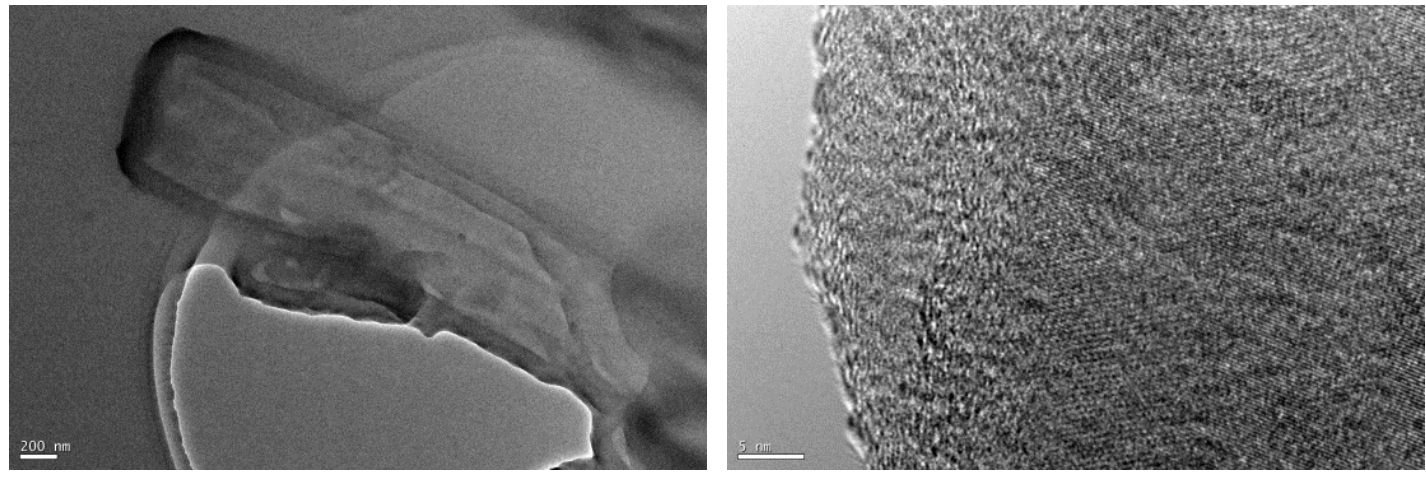

Figure S63. TEM images of LZU-565. 
Structural modeling of LZU-565 was generated by the Materials Studio (ver. $7.0)^{3}$ suite of programs. Possible stacking models (eclipsed and staggered) were constructed and optimized using the Forcite module. The calculated PXRD pattern was generated with the Reflex Plus module. Pawley refinement was applied for profile fitting, producing the refined PXRD profile with the lattice parameters of $a=b$ $=35.067( \pm 0.373) \AA$ and $c=4.254( \pm 0.045) \AA . R \mathrm{wp}$ and $R \mathrm{p}$ values converged to $8.21 \%$ and $6.44 \%$, respectively. Comparison of the observed and the simulated PXRD patterns (Figure S64) suggested that the preferable structure of LZU-565 is the eclipsed arrangement.

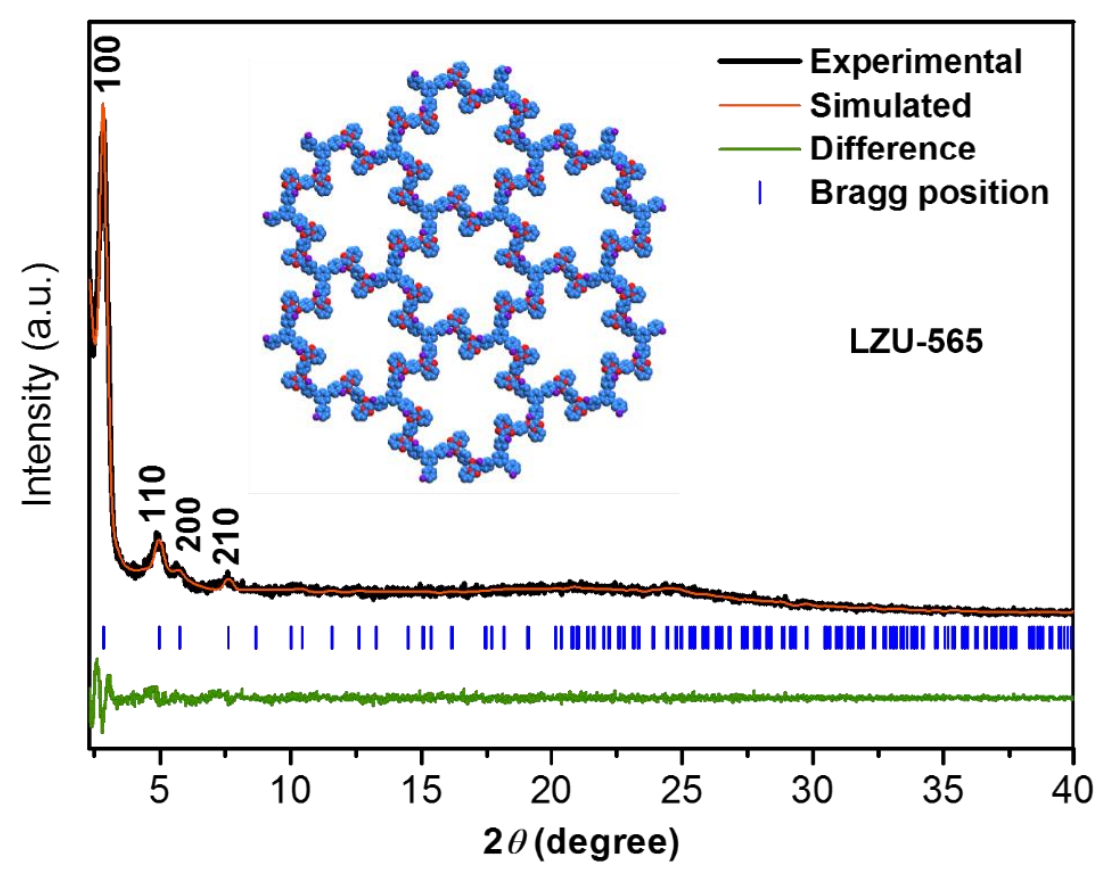

Figure S64. Indexed PXRD pattern and Pawley-refined profile of LZU-565. Inset: Structure of LZU-565 simulated with the eclipsed stacking model. C: blue, N: red, F: purple and $\mathrm{H}$ atoms are omitted for clarity. 


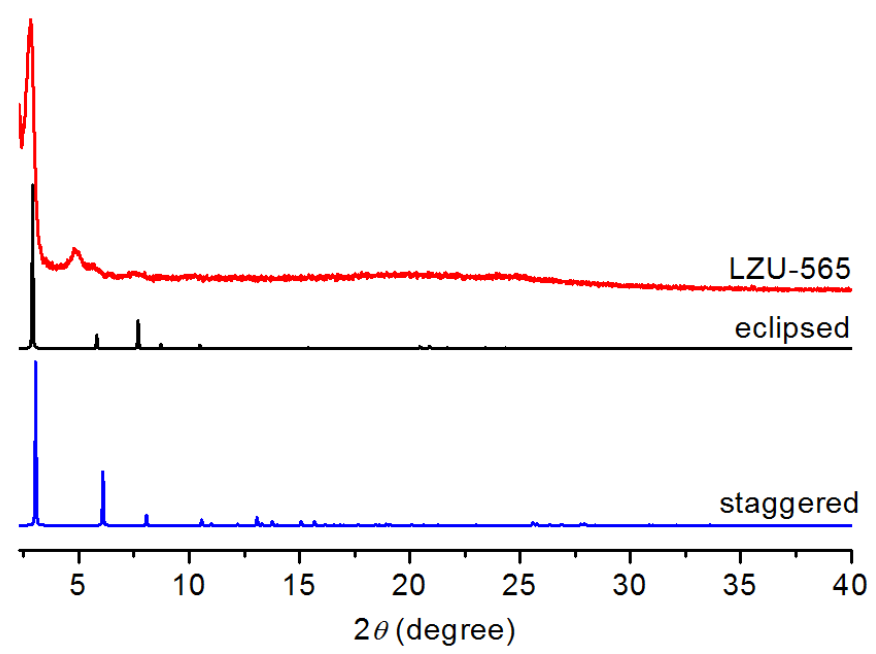

Figure S65. PXRD patterns of LZU-565: observed (red) and calculated with the eclipsed (black)/staggered (blue) stacking models. Comparison of the observed and the simulated PXRD patterns suggests that the preferable structure of LZU-565 is the eclipsed arrangement.

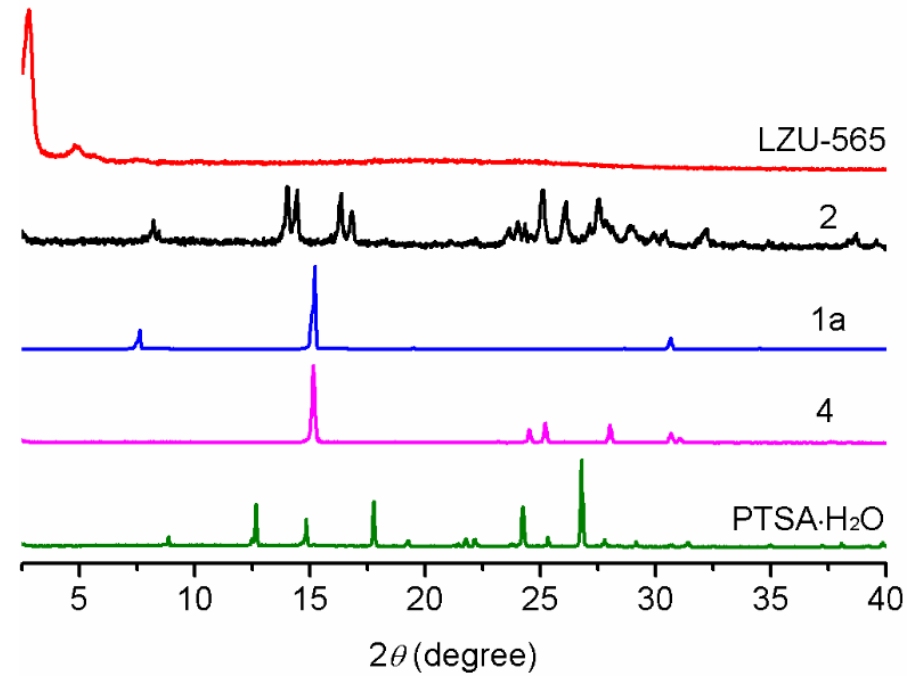

Figure S66. PXRD patterns of LZU-565 (red), the monomer 2 (black), the monomer $1 \mathrm{a}$ (blue), the monomer 4 (purple) and PTSA $\mathrm{H}_{2} \mathrm{O}$ (as the catalyst, green). No diffraction peaks from 1a, 2, 4, and PTSA $\cdot \mathrm{H}_{2} \mathrm{O}$ could be observed in the PXRD pattern of LZU-565, indicating the formation of new crystalline structure. 
Table S5. Fractional atomic coordinates for the unit cell of LZU-565.

\begin{tabular}{|c|c|c|c|c|c|c|c|}
\hline \multicolumn{8}{|c|}{ Space group: $P 3$} \\
\hline Atom & $\mathbf{X}(\AA)$ & $\mathbf{Y}(\AA)$ & $\mathbf{Z}(\AA)$ & Atom & $\mathbf{X}(\AA)$ & $\mathbf{Y}(\AA)$ & $Z(\AA)$ \\
\hline $\mathrm{C} 1$ & 2.04037 & 0.04198 & -0.7545 & $\mathrm{C} 34$ & 2.31943 & 0.20887 & -0.42533 \\
\hline $\mathrm{C} 2$ & 1.99993 & 0.04076 & -0.75528 & N35 & 2.40366 & 0.17565 & -0.2 \\
\hline $\mathrm{C} 3$ & 2.08229 & 0.08457 & -0.74652 & C36 & 2.41046 & 0.13849 & -0.2 \\
\hline $\mathrm{C} 4$ & 2.11787 & 0.08909 & -0.57181 & N37 & 2.37934 & 0.09533 & -0 . \\
\hline $\mathrm{C} 5$ & 2.1575 & 0.12901 & -0.56372 & $\mathrm{C} 38$ & 2.40194 & 0.07361 & -0.22363 \\
\hline C6 & 2.56225 & 0.16539 & -0.72977 & N39 & 2.44587 & 10018 & \\
\hline $\mathrm{C} 7$ & 2.12653 & 0.56111 & -0.90077 & $\mathrm{C} 40$ & 2.33457 & 0.07403 & -0. \\
\hline $\mathrm{C} 8$ & 2.08708 & 0.12106 & -0.91123 & $\mathrm{C} 41$ & 2.31129 & 0.02801 & -0.2 \\
\hline C9 & 2.20373 & 0.20811 & -0.72633 & $\mathrm{C} 42$ & 2.33438 & 0.00495 & -0.2 \\
\hline $\mathrm{C} 10$ & 2.24634 & 0.21516 & -0.74533 & $\mathrm{C} 43$ & 2.38042 & & \\
\hline N11 & 2.27 & & -0.77 & F44 & & & \\
\hline $\mathrm{C} 12$ & 2.24794 & 0.27695 & -0.75924 & $\mathrm{H} 45$ & 1.9991 & 0.07116 & -0.75324 \\
\hline N13 & 2.2048 & 0.24719 & -0.7332 & $\mathrm{H} 46$ & 2.11478 & 0.06199 & -0.43521 \\
\hline N14 & 2.25767 & 0.18156 & -0.79576 & $\mathrm{H} 47$ & 2.12947 & 0.18859 & -1 . \\
\hline $\mathrm{C} 15$ & 2.31777 & 0.28288 & -0.83195 & $\mathrm{H} 48$ & 2.06062 & 848 & -1. \\
\hline $\mathrm{C} 16$ & 2.33708 & 0.32855 & -0.86353 & $\mathrm{H} 49$ & 2.2354 & 414 & -0. \\
\hline $\mathrm{C} 17$ & & & -0.84017 & & & & \\
\hline C18 & 2.26541 & 0.32217 & -0.78959 & H51 & 2.32545 & 34 & -0.86 \\
\hline F19 & 2.19045 & 0.1323 & -0.38489 & H52 & 2.24459 & 0.33673 & -0.77945 \\
\hline $\mathrm{C} 20$ & 2.62455 & 0.29551 & -0.19895 & H53 & 2.6591 & 0.25919 & -0.19901 \\
\hline $\mathrm{C} 21$ & 2.6624 & 0.29155 & -0.19878 & H54 & 2.55302 & 0.2803 & 0.13844 \\
\hline $\mathrm{C} 22$ & 2.5802 & 0.25577 & -0.20094 & H55 & 2.52308 & 32 & -0.54 \\
\hline $\mathrm{C} 23$ & 2.54651 & 0.25363 & -0.01597 & H56 & 2.59654 & 0.22035 & -0.53227 \\
\hline $\mathrm{C} 24$ & 2.50464 & 0.25628 & -0.01794 & H57 & 2.28488 & 0.12539 & -0.93706 \\
\hline $\mathrm{C} 25$ & 2.4953 & 0.18095 & -0.2141 & $\mathrm{H} 58$ & 2.37529 & 0.23059 & -0.13006 \\
\hline $\mathrm{C} 26$ & 2.52931 & 0.1825 & -0.3914 & H59 & 2.42995 & 0.20676 & -0.23449 \\
\hline $\mathrm{C} 27$ & 2.57132 & 0.21956 & -0.38578 & H60 & 2.27574 & 0.01038 & -0.19716 \\
\hline $\mathrm{C} 28$ & 2.45134 & 0.1411 & -0.22502 & H61 & 2.31659 & -0.03059 & -0.18898 \\
\hline C29 & 2.29406 & 0.17994 & -0.65858 & H62 & 2.39866 & 0.01056 & -0.19636 \\
\hline $\mathrm{C} 30$ & 2.30438 & 0.14827 & -0.75945 & H63 & 0.31136 & 0.23256 & 0.66405 \\
\hline $\mathrm{C} 31$ & 2.34088 & 0.14723 & -0.64253 & H64 & 0.33773 & 0.26765 & 0.14242 \\
\hline C32 & 2.36593 & 0.17583 & -0.40813 & H65 & 0.77478 & 0.68336 & 0.78548 \\
\hline $\mathrm{C} 33$ & 2.35574 & 0.20759 & -0.30731 & H66 & 0.77446 & 0.65051 & 0.26849 \\
\hline
\end{tabular}




\section{Synthesis and Characterization of LZU-566}

Synthesis of LZU-566

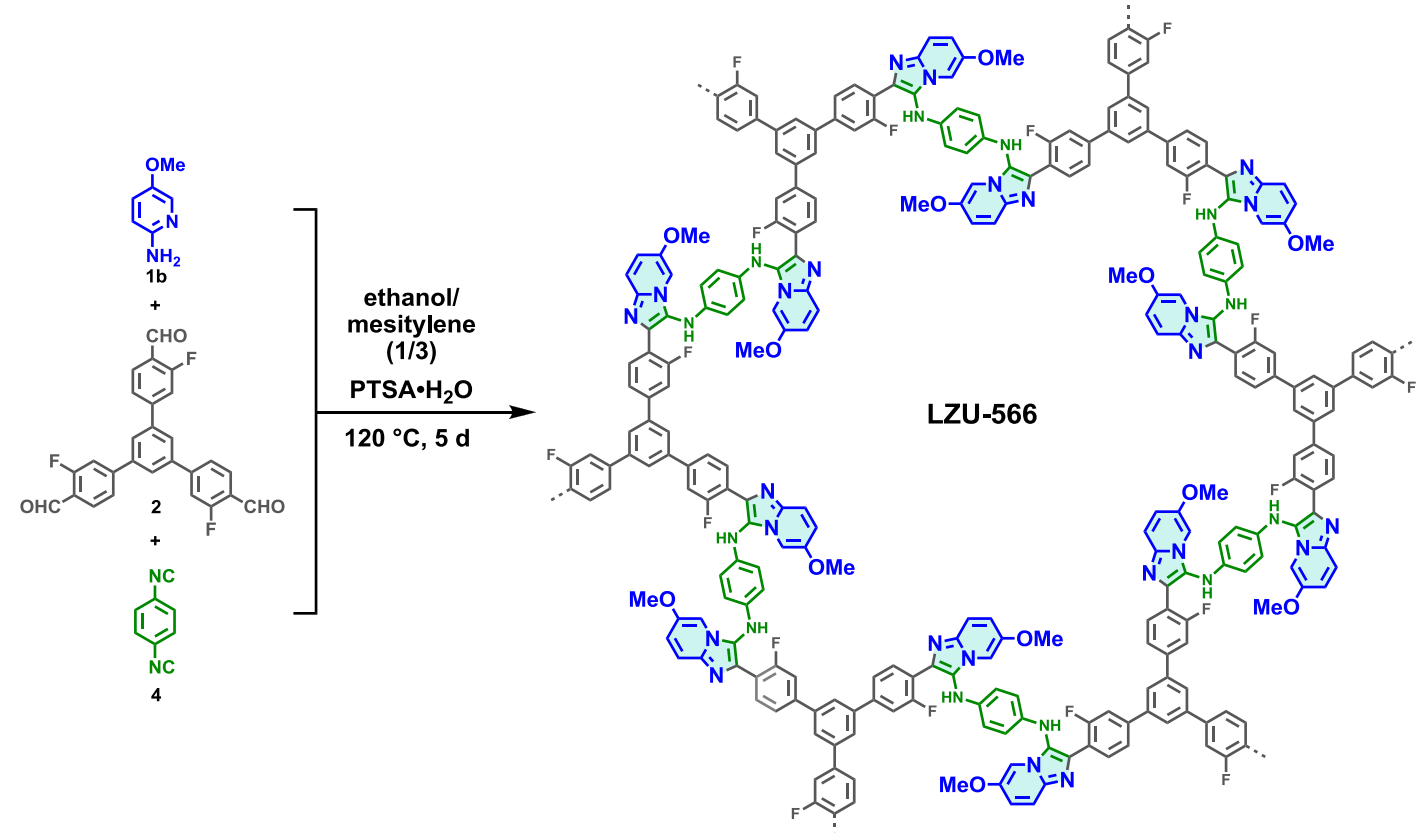

The synthetic procedure of LZU-566 was similar to that of LZU-561. Condensation of 2-amino-5-methoxypyridine $\mathbf{1 b}(22.6 \mathrm{mg}, 0.182 \mathrm{mmol}), 1,3,5$-tris

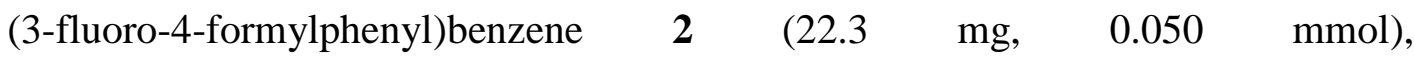
1,4-diisocyanobenzene $4(9.7 \mathrm{mg}, \quad 0.075 \mathrm{mmol})$ and $p$-toluenesulfonic acid monohydrate $(7.0 \mathrm{mg}, 0.037 \mathrm{mmol})$ yielded LZU-566 as a dark green powder (36.9 mg, 77\% yield). Anal. Cald for $\left(\mathrm{C}_{19} \mathrm{H}_{13} \mathrm{~N}_{3} \mathrm{OF}\right) n$ : $\mathrm{C} 71.69 ; \mathrm{H} 4.12 ; \mathrm{N} 13.20$, found: $\mathrm{C}$ $67.95 ; \mathrm{H} 4.00 ; \mathrm{N}$ 10.95. Characterization of LZU-566 was presented in the main text and in this SI.

The synthesis of ${ }^{13} \mathrm{C}$-labeled LZU-566 was similar to that of LZU-566. Condensation of 2-amino-5-methoxypyridine 1b, 1,3,5-tris(3-fluoro-4-formyl phenyl)benzene 2 , and ${ }^{13} \mathrm{C}$-labeled 1 ,4-diisocyanobenzene $4\left(-\mathrm{N} \equiv{ }^{13} \mathrm{C}\right)$ yielded ${ }^{13}$ C-labeled LZU-566. 
Characterization of $L Z U-566$

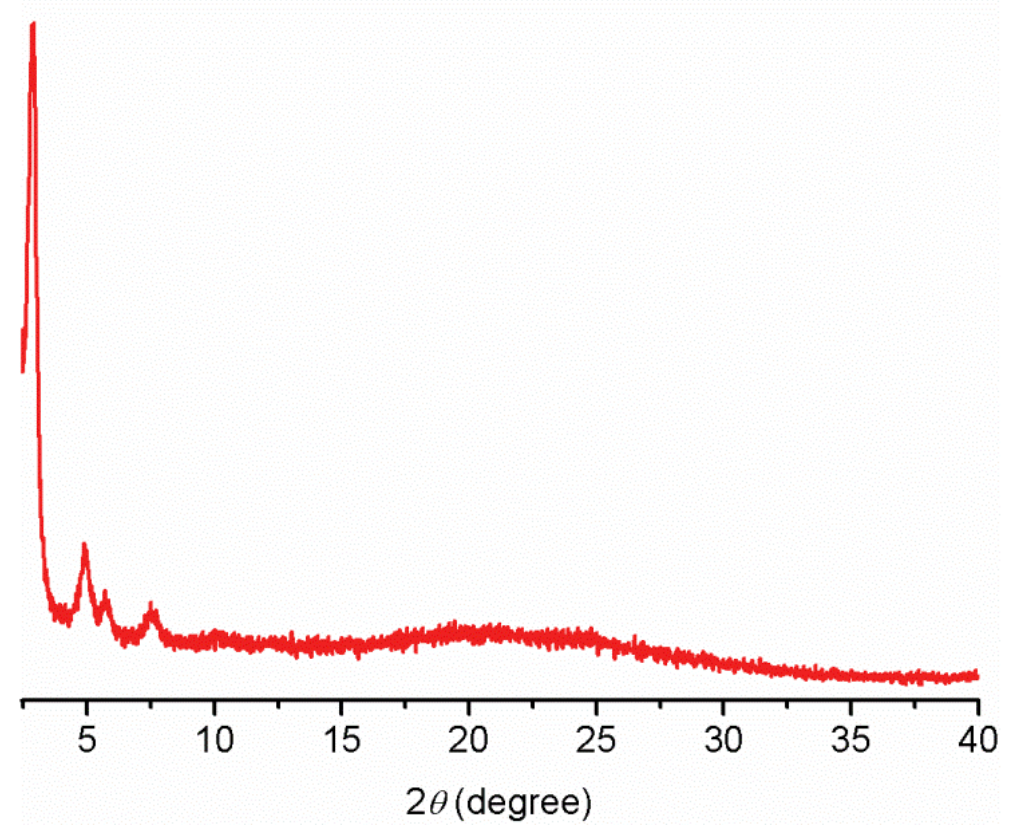

Figure S67. PXRD pattern of LZU-566 (ethanol/mesitylene (1/3), $120^{\circ} \mathrm{C}, 5$ days).

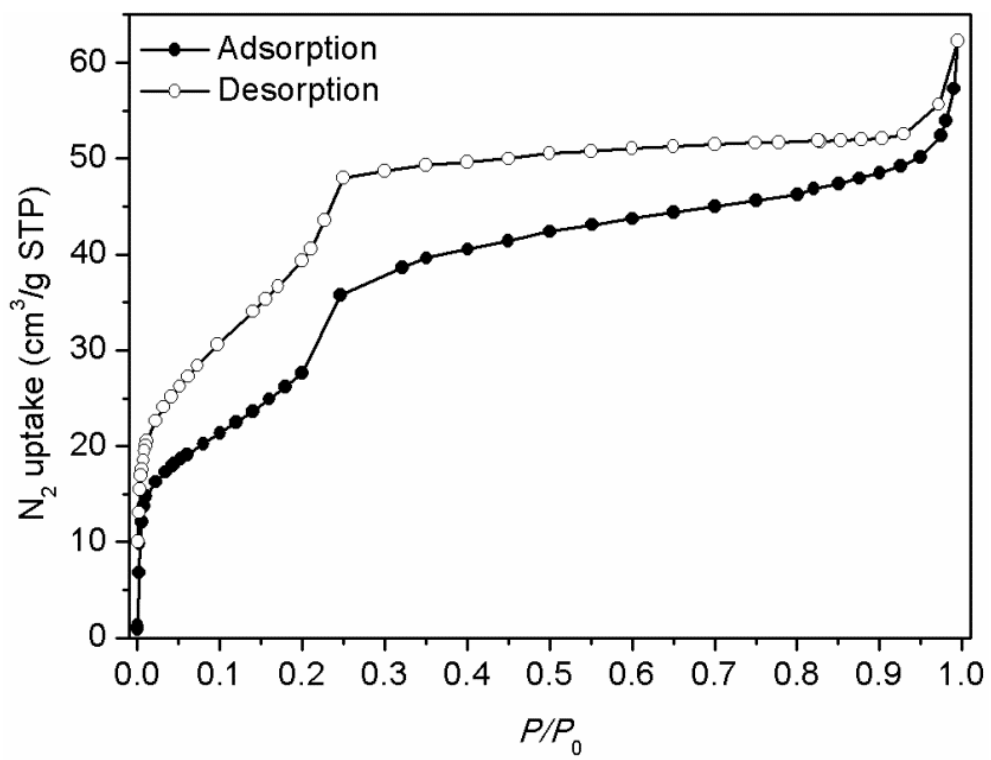

Figure S68. $\mathrm{N}_{2}$ adsorption and desorption isotherms of LZU-566. 


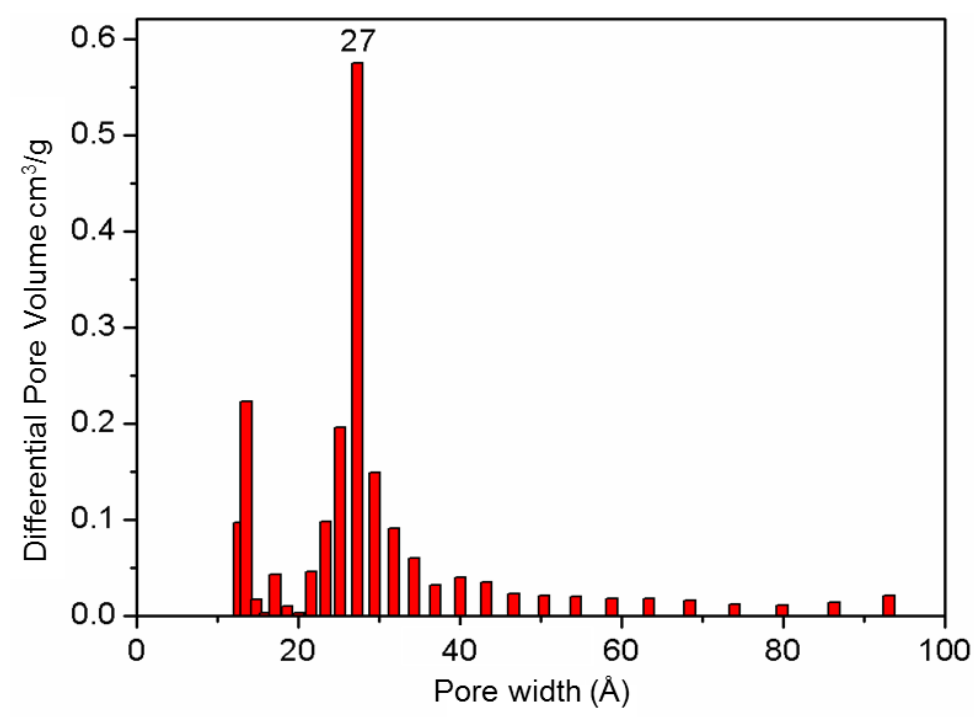

Figure S69. Pore size distribution of LZU-566 calculated by NLDFT (slit pores model).

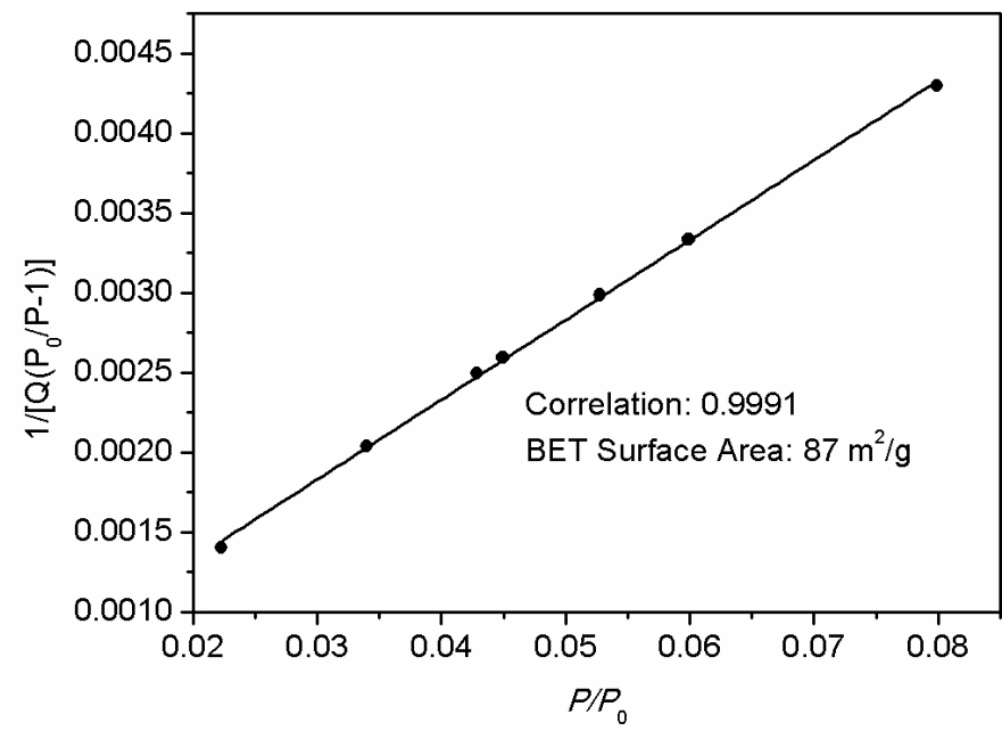

Figure S70. BET surface area plot for LZU-566 calculated from the adsorption isotherm. 


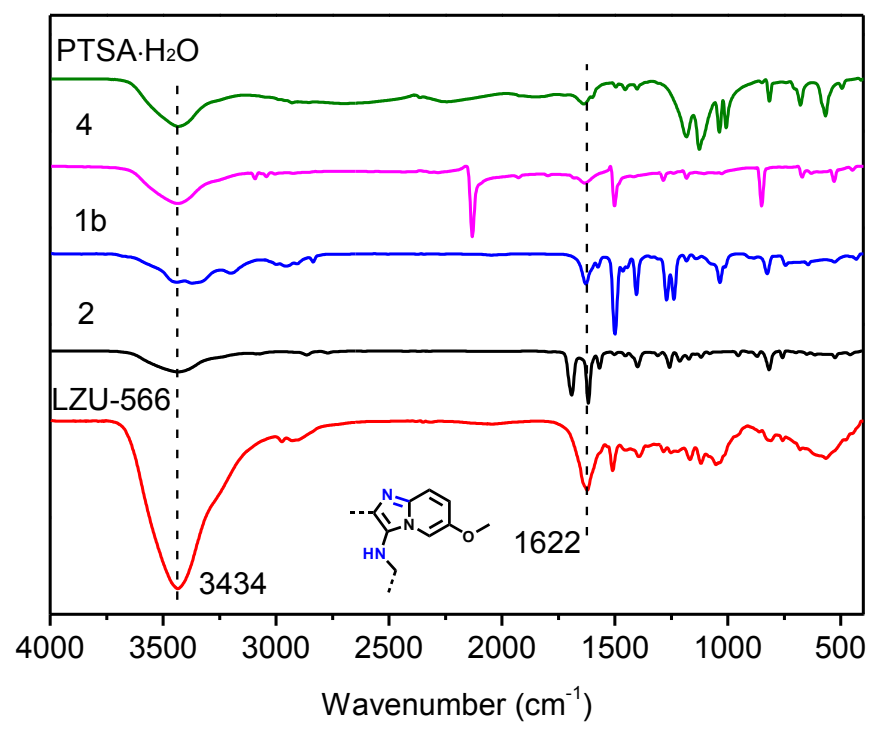

Figure S71. FT-IR spectra of LZU-566 (red), the monomer 2 (black), monomer 1b (blue), monomer 4 (purple), and PTSA $\cdot \mathrm{H}_{2} \mathrm{O}$ (as the catalyst, green). The FT-IR spectrum of LZU-566 (red) shows stretches at $1622 \mathrm{~cm}^{-1}$, indicating the formation of the pyrimodazole ring.

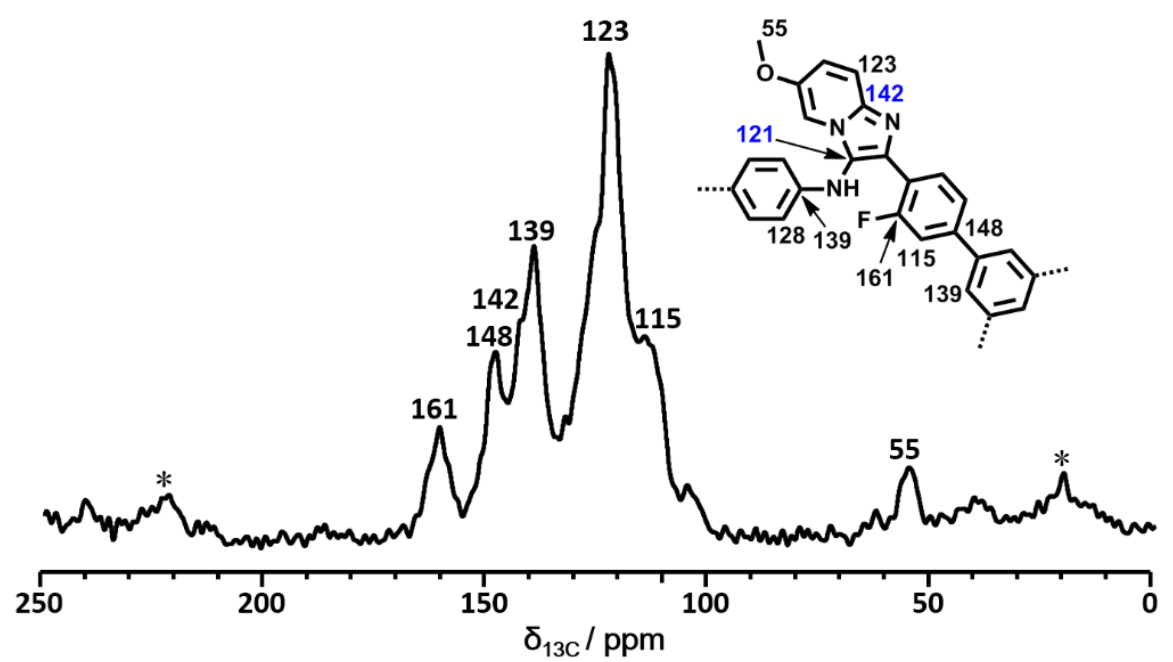

Figure S72. ${ }^{13} \mathrm{C} \mathrm{CP} / \mathrm{MAS}$ NMR spectrum of LZU-566. The assignments of ${ }^{13} \mathrm{C}$ chemical shifts of LZU-566 were indicated in the chemical structure. 


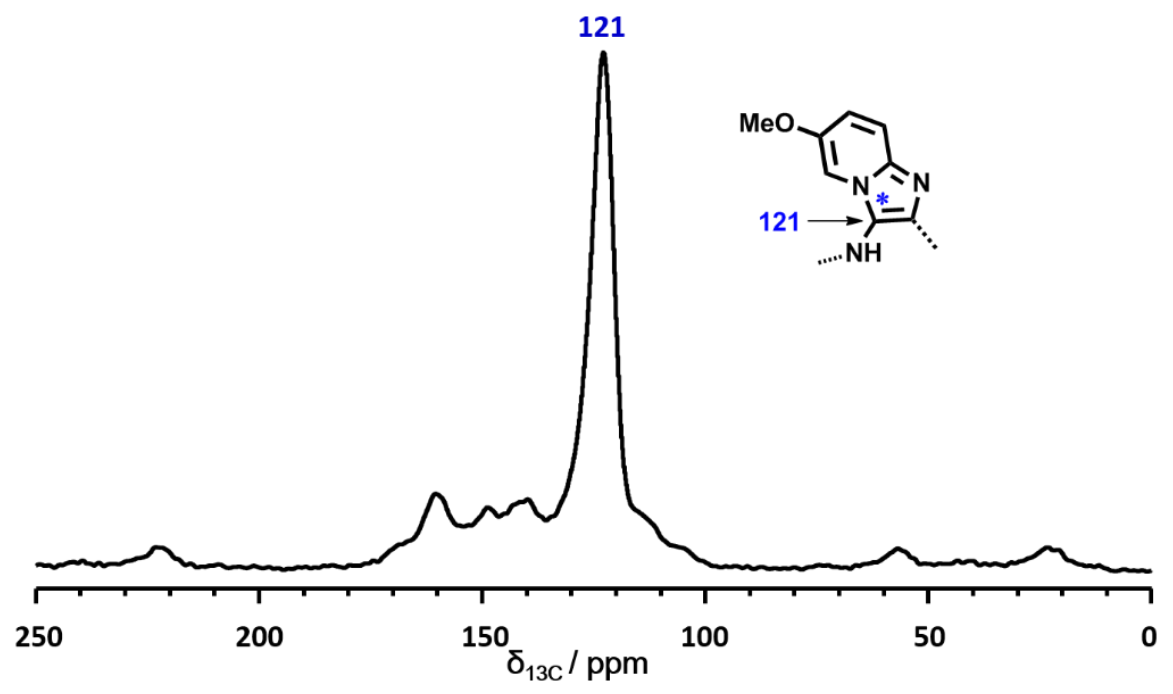

Figure S73. ${ }^{13} \mathrm{C} \mathrm{CP} / \mathrm{MAS}$ NMR spectrum of ${ }^{13} \mathrm{C}$-labeled LZU-566. The ${ }^{13} \mathrm{C}$-labeled LZU-566 was made by ${ }^{13} \mathrm{C}$ labeled 1,4-diisocyanobenzene $\left(-\mathrm{N} \equiv{ }^{13} \mathrm{C}\right)$. The presence of the peak at $121 \mathrm{ppm}$ indicates the formation of pyrimidazole ring with the ${ }^{13} \mathrm{C}$-labeled atom as *.

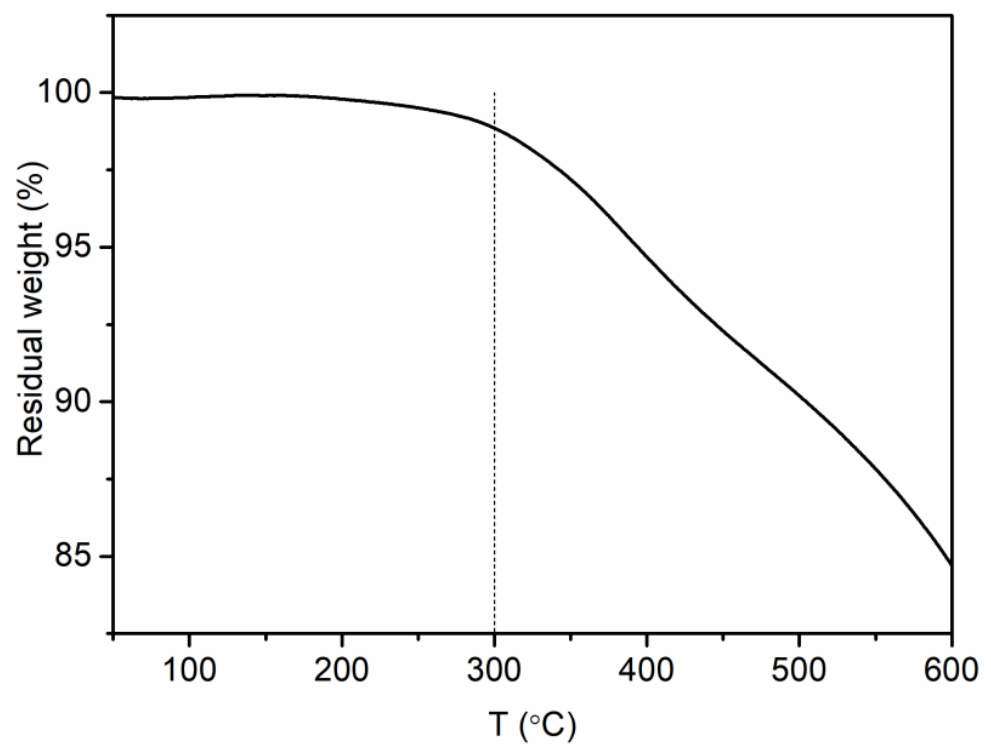

Figure S74. TGA data of LZU-566, indicating that LZU-566 is thermally stable up to $300^{\circ} \mathrm{C}$. 

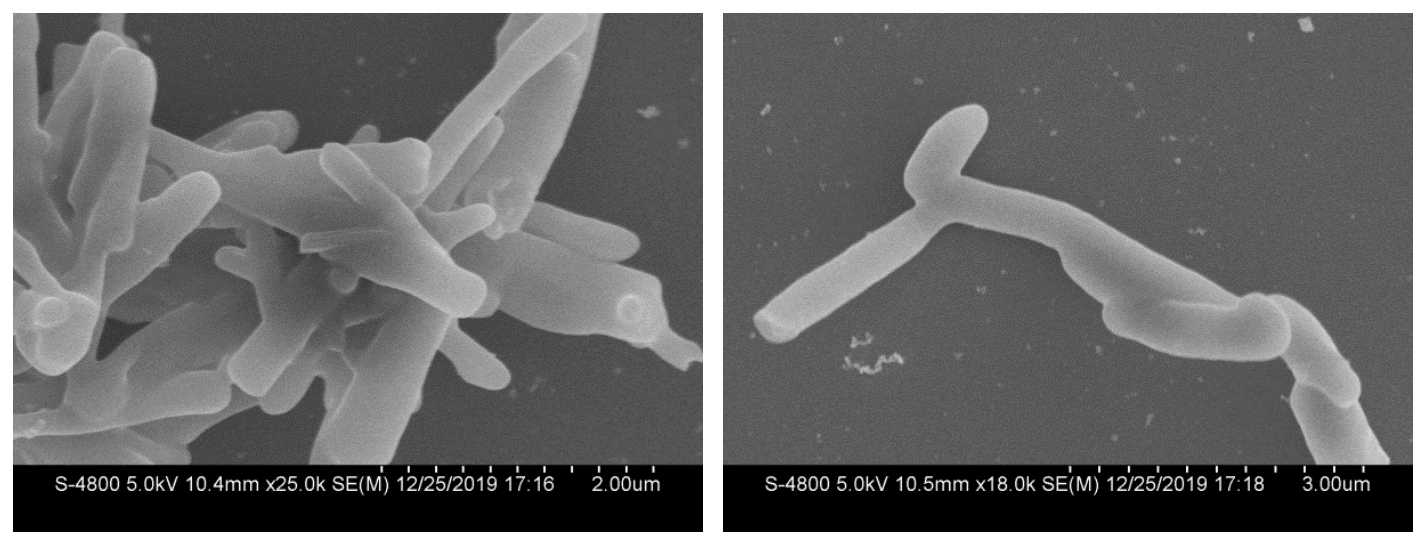

Figure S75. SEM images of LZU-566.
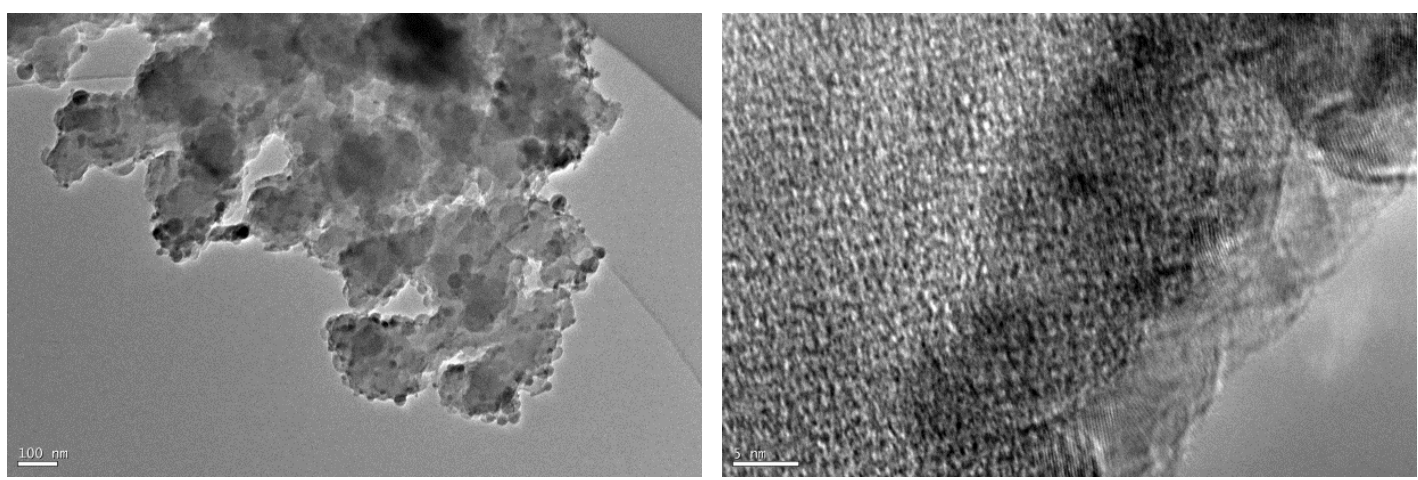

Figure S76. TEM images of LZU-566. 
Structural modeling of LZU-566

The structural modeling of LZU-566 is similar to that of LZU-565. The Pawley refined lattice parameters were determined as: $a=b=34.725( \pm 0.393) \AA$ and $c=$ 4.320 ( \pm 0.049$) \AA$. $R \mathrm{wp}$ and $R \mathrm{p}$ values converged to $8.41 \%$ and $6.44 \%$, respectively. Comparison of the observed and the simulated PXRD patterns (Figure S77) suggested that the preferable structure of LZU-566 is the eclipsed arrangement.

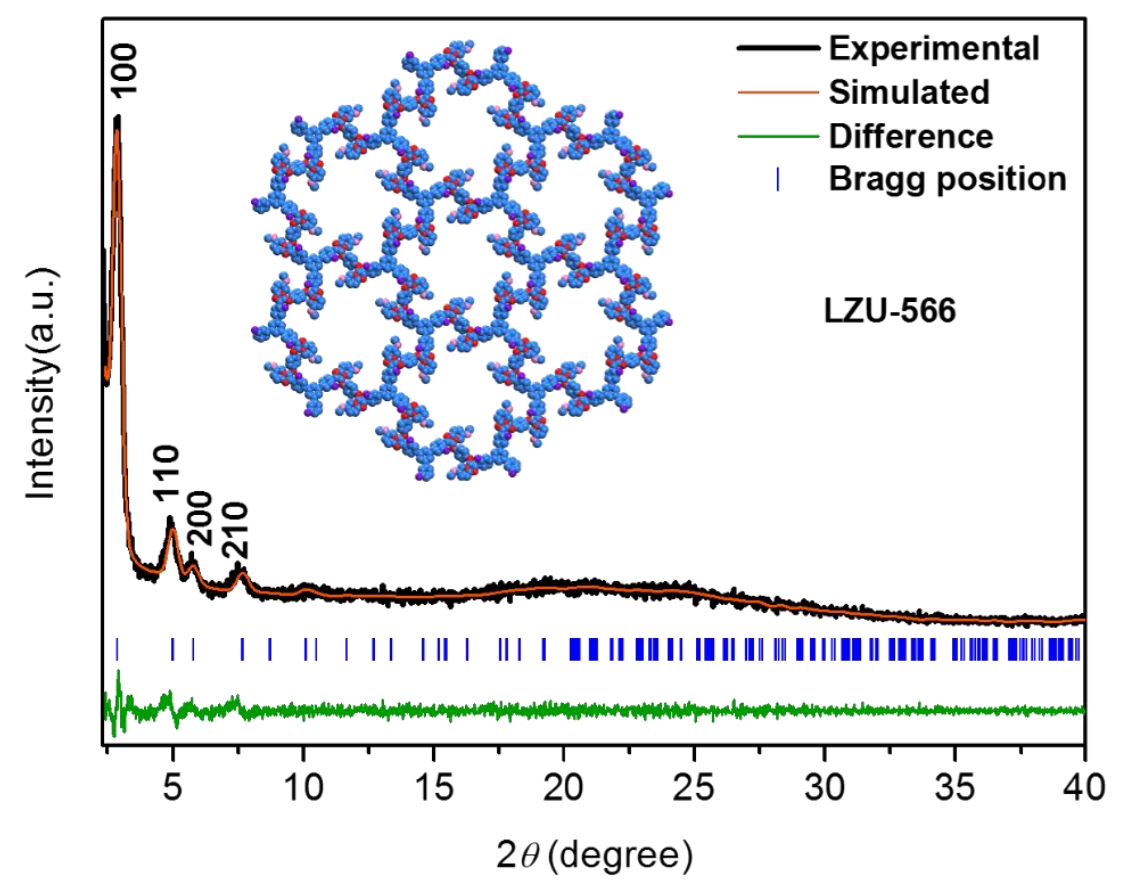

Figure S77. Indexed PXRD pattern and Pawley-refined profile of LZU-566. Inset: Structure of LZU-566 simulated with the eclipsed stacking model. C: blue, N: red, F: purple, $\mathrm{O}$ : pink and $\mathrm{H}$ atoms are omitted for clarity. 


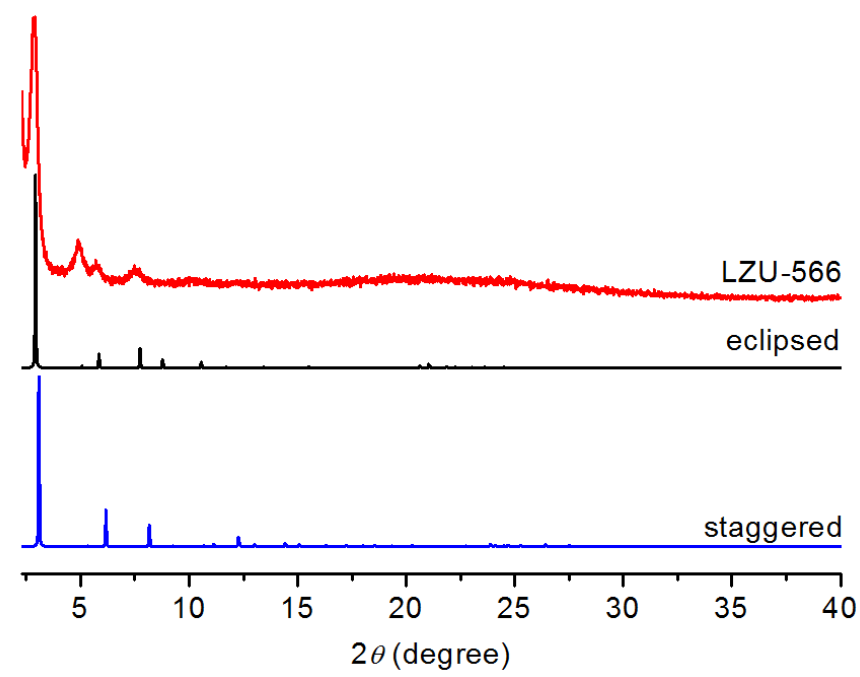

Figure S78. PXRD patterns of LZU-566: observed (red) and calculated with the eclipsed (black)/staggered (blue) stacking models. Comparison of the observed and the simulated PXRD patterns suggests that the preferable structure of LZU-566 is the eclipsed arrangement.

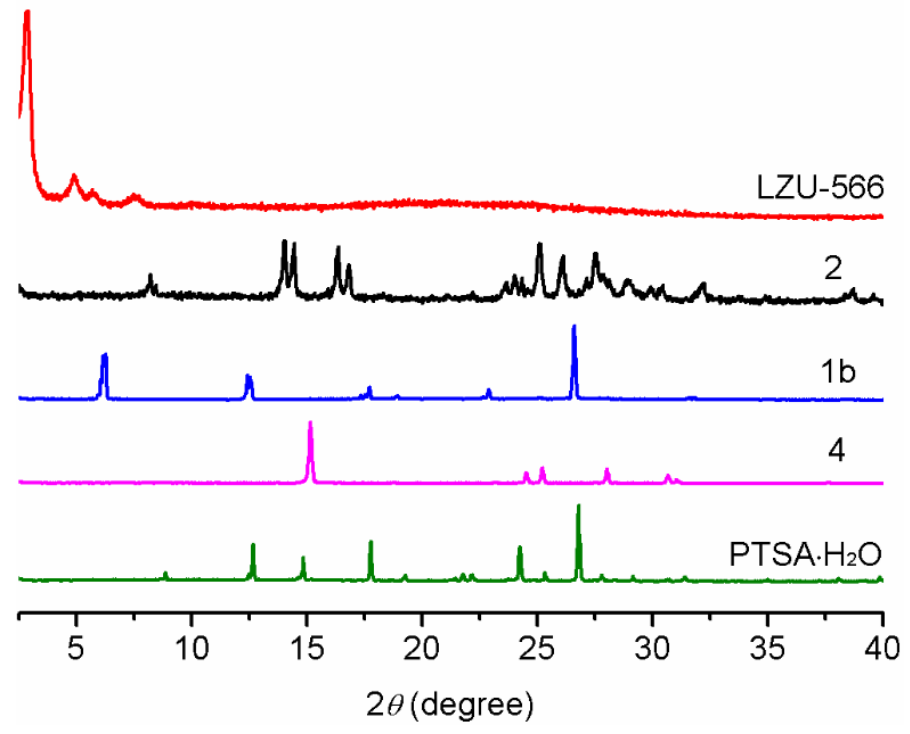

Figure S79. PXRD patterns of LZU-566 (red), the monomer 2 (black), the monomer 1 b (blue), the monomer 4 (purple) and PTSA $\cdot \mathrm{H}_{2} \mathrm{O}$ (as the catalyst, green). No diffraction peaks from $\mathbf{1 b}, \mathbf{2}, \mathbf{4}$, and PTSA $\cdot \mathrm{H}_{2} \mathrm{O}$ could be observed in the PXRD pattern of LZU-566, indicating the formation of new crystalline structure. 
Table S6. Fractional atomic coordinates for the unit cell of LZU-566.

\begin{tabular}{|c|c|c|c|c|c|c|c|}
\hline \multicolumn{8}{|c|}{$\begin{array}{c}\text { Space group: } P 3 \\
a=b=34.872 \AA ⿻ \text { 的 } c=4.348 \AA, \alpha=\beta=90^{\circ}, \gamma=120^{\circ}\end{array}$} \\
\hline Atom & $\mathbf{X}(\AA)$ & $\mathbf{Y}(\AA)$ & $\mathbf{Z}(\AA)$ & Atom & $\mathbf{X}(\AA)$ & $\mathbf{Y}(\AA)$ & $\mathbf{Z}(\AA)$ \\
\hline $\mathrm{C} 1$ & 2.03973 & 0.04305 & -0.76894 & $\mathrm{C} 38$ & 2.39729 & 0.0747 & -0.21268 \\
\hline $\mathrm{C} 2$ & 1.99826 & 0.04018 & -0.77079 & N39 & 2.44563 & 0.1007 & -0.20319 \\
\hline $\mathrm{C} 3$ & 2.08101 & 0.08673 & -0.75351 & $\mathrm{C} 40$ & 2.33034 & 0.07676 & -0.2563 \\
\hline $\mathrm{C} 4$ & 2.117 & 0.09193 & -0.57639 & $\mathrm{C} 41$ & 2.30552 & 0.03038 & -0.19825 \\
\hline $\mathrm{C} 5$ & 2.1561 & 0.13275 & -0.56181 & $\mathrm{C} 42$ & 2.32848 & 0.00636 & -0.19085 \\
\hline C6 & 2.15995 & 0.56848 & -0.72259 & $\mathrm{C} 43$ & 2.37481 & 0.02872 & -0.19564 \\
\hline $\mathrm{C} 7$ & 2.12373 & 0.56459 & -0.89484 & F44 & 2.47244 & 0.21593 & 0.1977 \\
\hline $\mathrm{C} 8$ & 2.08479 & 0.12358 & -0.91248 & $\mathrm{H} 45$ & 1.99617 & 0.07011 & -0.7679 \\
\hline C9 & 2.2012 & 0.21297 & -0.7154 & $\mathrm{H} 46$ & 2.11466 & 0.06461 & -0.44325 \\
\hline $\mathrm{C} 10$ & 2.24438 & 0.22087 & -0.73672 & $\mathrm{H} 47$ & 2.12596 & 0.1923 & -1.02266 \\
\hline N11 & 2.2714 & 0.26493 & -0.76715 & $\mathrm{H} 48$ & 2.05801 & 0.12057 & -1.0555 \\
\hline $\mathrm{C} 12$ & 2.24474 & 0.28244 & -0.75146 & $\mathrm{H} 49$ & 2.2341 & 0.1603 & -0.92422 \\
\hline $\mathrm{N} 13$ & 2.20149 & 0.25193 & -0.72245 & $\mathrm{O} 50$ & 2.37997 & 0.35964 & -0.94503 \\
\hline N14 & 2.25637 & 0.18765 & -0.79529 & H51 & 2.31972 & 0.38955 & -0.87592 \\
\hline $\mathrm{C} 15$ & 2.31535 & 0.28949 & -0.83304 & H52 & 2.24 & 0.34176 & -0.77537 \\
\hline $\mathrm{C} 16$ & 2.33444 & 0.33538 & -0.87419 & & 2.65772 & 0.25813 & -0.18749 \\
\hline $\mathrm{C} 17$ & 2.30684 & 0.35443 & -0.84663 & H54 & 2.55224 & 0.28188 & 0.15054 \\
\hline $\mathrm{C} 18$ & 2.26148 & 0.32769 & -0.7869 & H55 & 2.52005 & 0.15487 & -0.52728 \\
\hline F19 & 2.18953 & 0.13641 & -0.38302 & H56 & 2.59459 & 0.21947 & -0.51975 \\
\hline $\mathrm{C} 20$ & 2.62394 & 0.29569 & -0.18748 & H57 & 2.282 & 0.12966 & -0.93225 \\
\hline $\mathrm{C} 21$ & 2.66562 & 0.29095 & -0.18737 & H58 & 2.37524 & 0.23612 & -0.12843 \\
\hline $\mathrm{C} 22$ & 2.57895 & 0.25613 & -0.18892 & H59 & 2.42846 & 0.2097 & -0.2256 \\
\hline $\mathrm{C} 23$ & 2.54526 & 0.25478 & -0.00394 & O60 & 2.25903 & 0.01062 & -0.18459 \\
\hline $\mathrm{C} 24$ & 2.50277 & 0.21768 & -0.00576 & H61 & 2.31113 & -0.02936 & -0.17673 \\
\hline $\mathrm{C} 25$ & 2.49278 & 0.18179 & -0.20198 & H62 & 2.3926 & 0.01072 & -0.18277 \\
\hline $\mathrm{C} 26$ & 2.52678 & 0.18249 & -0.37874 & H63 & 0.31179 & 0.23959 & 0.66151 \\
\hline $\mathrm{C} 27$ & 2.56941 & 0.21932 & -0.37322 & H64 & 0.33559 & 0.27432 & 0.14051 \\
\hline $\mathrm{C} 28$ & 2.44809 & 0.14226 & -0.21388 & H65 & 0.78197 & 0.68683 & 0.79188 \\
\hline $\mathrm{C} 29$ & 2.29278 & 0.18558 & -0.6572 & H66 & 0.7806 & 0.65364 & 0.27559 \\
\hline $\mathrm{C} 30$ & 2.30218 & 0.15289 & -0.75582 & C67 & 0.39905 & 0.40568 & -0.01152 \\
\hline $\mathrm{C} 31$ & 2.3385 & 0.1511 & -0.63757 & H68 & 0.38244 & 0.41069 & -0.21303 \\
\hline $\mathrm{C} 32$ & 2.36424 & 0.17993 & -0.40328 & H69 & 0.43452 & 0.41935 & -0.06933 \\
\hline $\mathrm{C} 33$ & 2.35511 & 0.21288 & -0.30541 & $\mathrm{H} 70$ & 0.39708 & 0.42379 & 0.19257 \\
\hline $\mathrm{C} 34$ & 2.31905 & 0.215 & -0.42562 & $\mathrm{C} 71$ & 0.73025 & 0.76663 & 0.84378 \\
\hline $\mathrm{N} 35$ & 2.40156 & 0.17866 & -0.27528 & $\mathrm{H} 72$ & 0.71063 & 0.75813 & 1.0596 \\
\hline C36 & 2.40738 & 0.14058 & -0.2397 & $\mathrm{H} 73$ & 0.70886 & 0.76158 & 0.64096 \\
\hline N37 & 2.37537 & 0.09734 & -0.23015 & $\mathrm{H} 74$ & 0.75591 & 0.80219 & 0.85362 \\
\hline
\end{tabular}


Synthesis of $L Z U-567$

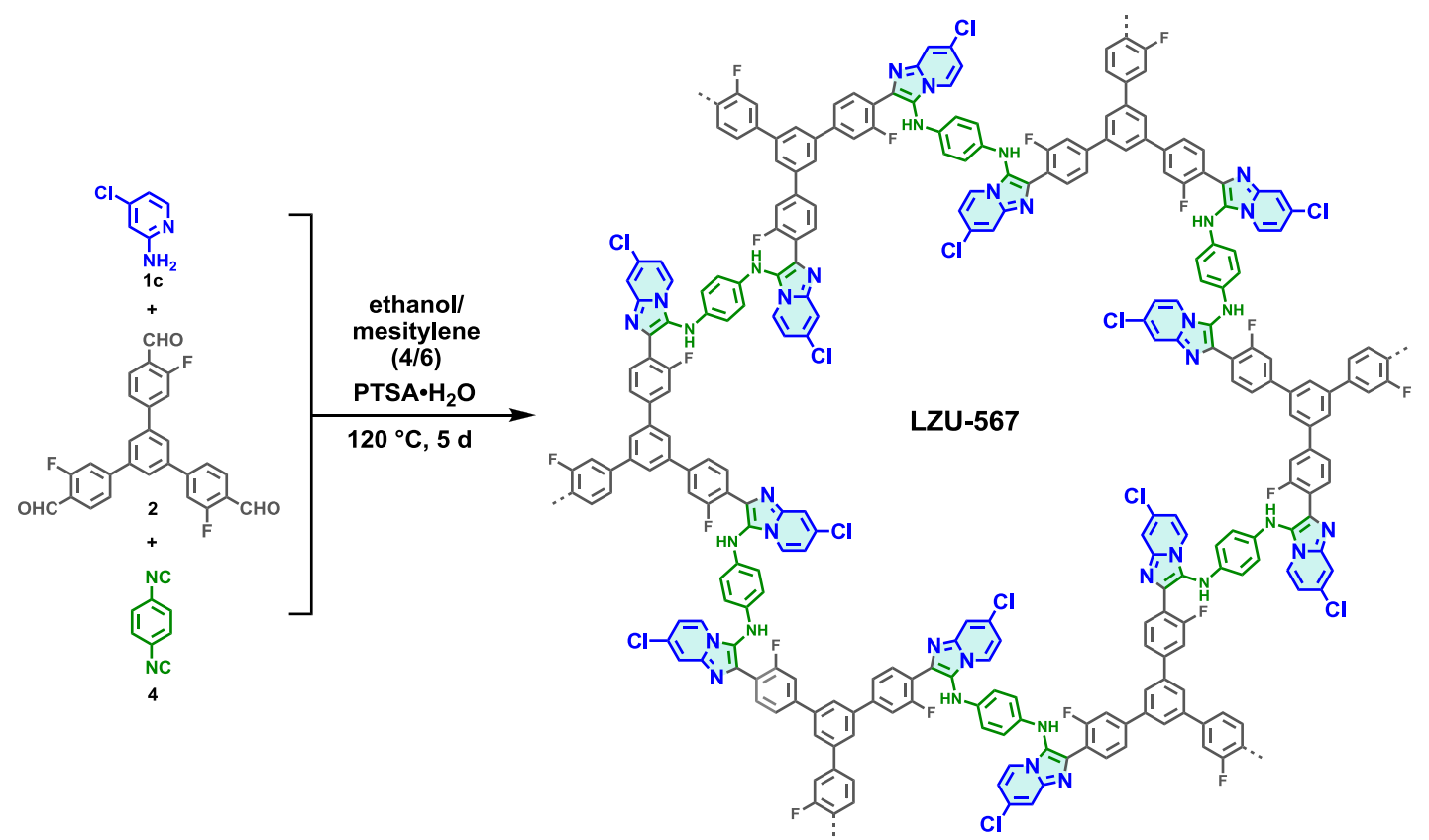

The synthetic procedure of LZU-567 was similar to that of LZU-561. Condensation of 2-amino-4-chloropyridine $1 \mathrm{c}(19.5 \mathrm{mg}, 0.151 \mathrm{mmol})$, 1,3,5-tris (3-fluoro-4-formylphenyl)benzene 2 (11.3 mg, $0.025 \mathrm{mmol}$ ), 1,4-diisocyanobenzene 4 (5.4 mg, $0.042 \mathrm{mmol})$ and $p$-toluenesulfonic acid monohydrate $(3.5 \mathrm{mg}, 0.018 \mathrm{mmol})$ yielded LZU-567 as a brownish yellow powder (20.1 mg, 83\% yield). Anal. Cald for $\left(\mathrm{C}_{18} \mathrm{H}_{10} \mathrm{~N}_{3} \mathrm{FCl}\right)_{\mathrm{n}}$ : $\mathrm{C}$ 66.99; $\mathrm{H}$ 3.12; N 13.02, found: C 65.30; H 3.84; N 10.47. Characterization of LZU-567 was presented in the main text and in this SI.

The synthesis of ${ }^{13} \mathrm{C}$-labeled LZU-567 was similar to that of LZU-567. Condensation of 2-amino-4-chloropyridine 1c, 1,3,5-tris(3-fluoro-4-formyl phenyl)benzene 2 , and ${ }^{13} \mathrm{C}$-labeled 1,4-diisocyanobenzene $4 \quad\left(-\mathrm{N} \equiv{ }^{13} \mathrm{C}\right)$ yielded ${ }^{13}$ C-labeled LZU-567. 
Characterization of $L Z U-567$

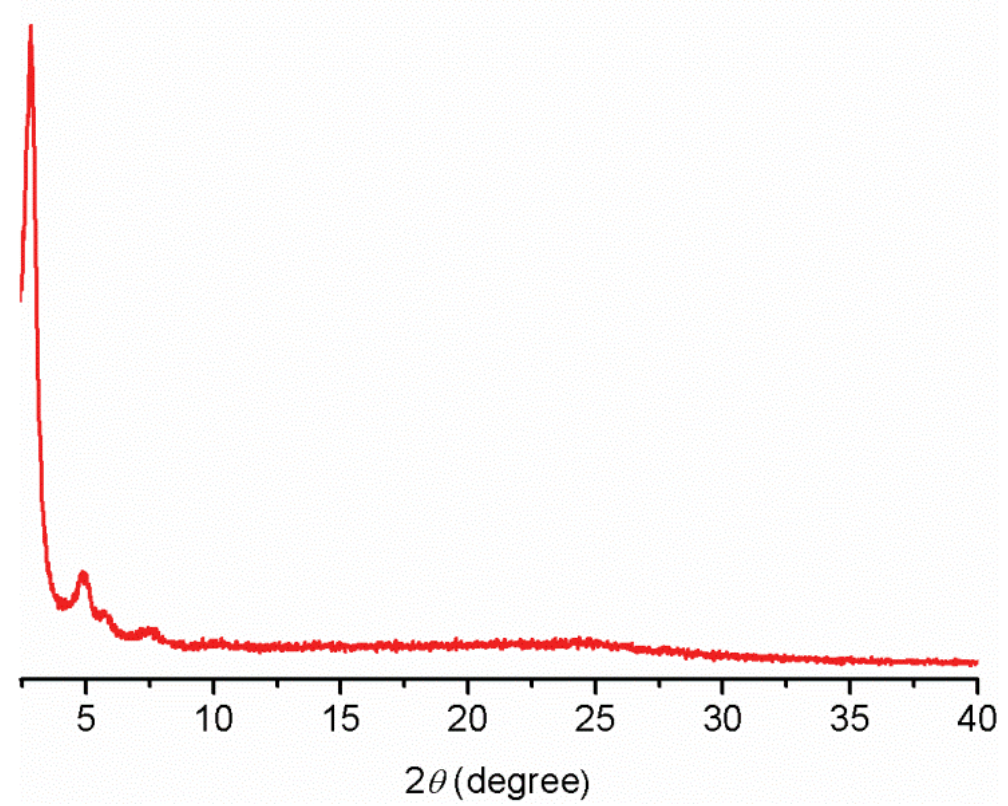

Figure S80. PXRD pattern of LZU-567 (ethanol/mesitylene (4/6), $120{ }^{\circ} \mathrm{C}, 5$ days).

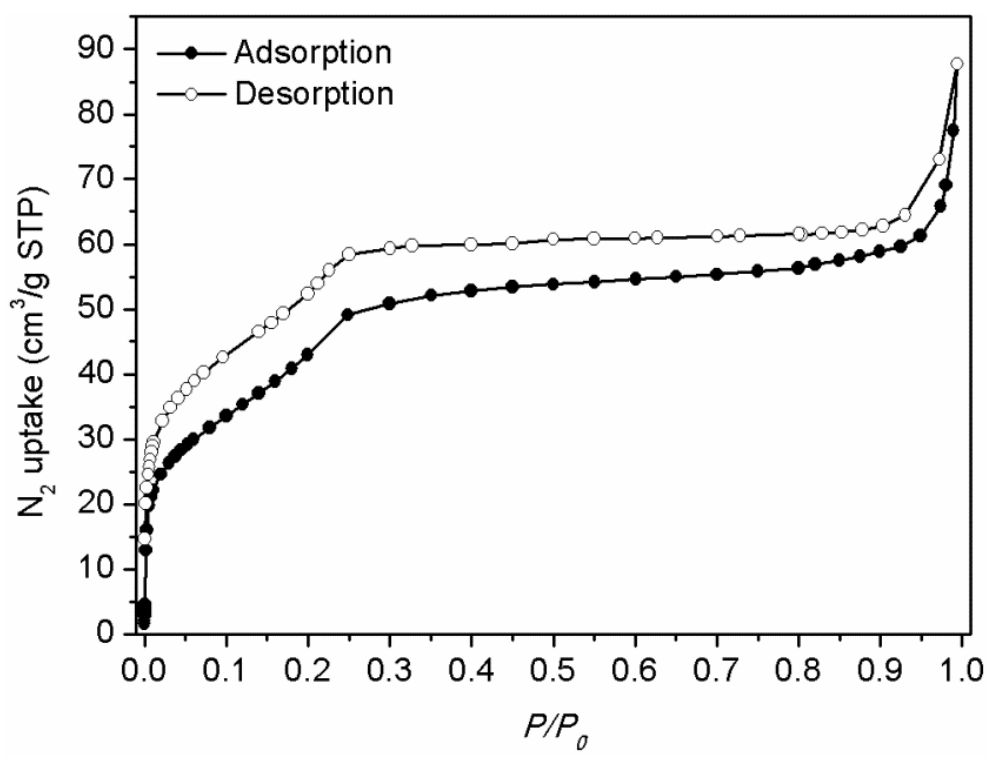

Figure S81. $\mathrm{N}_{2}$ adsorption and desorption isotherms of LZU-567. 


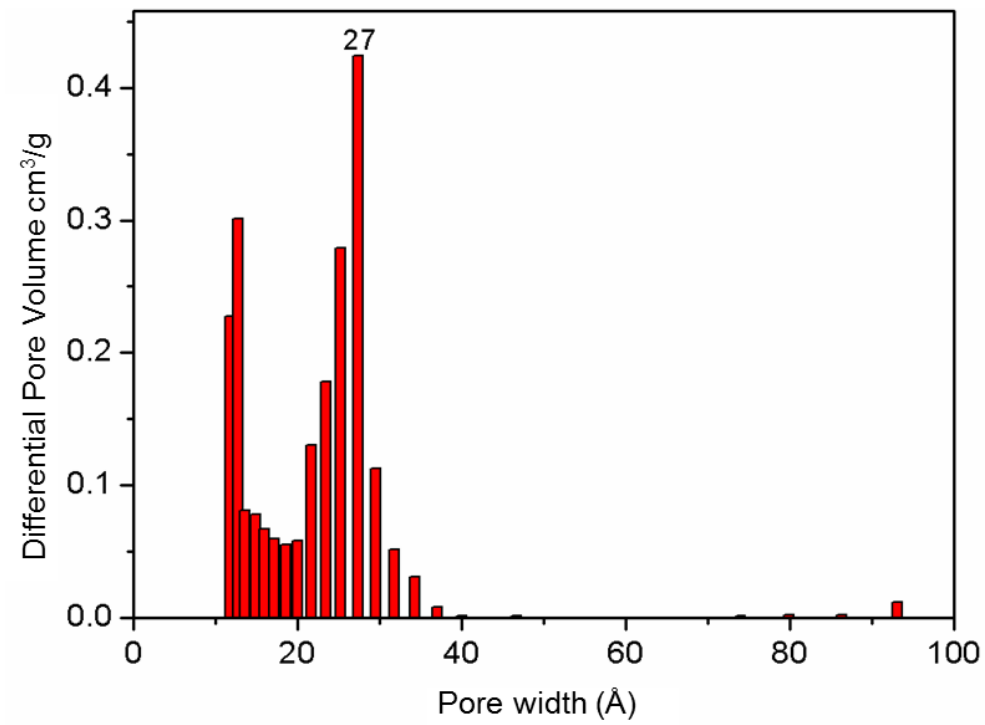

Figure S82. Pore size distribution of LZU-567 calculated by NLDFT (slit pores model).

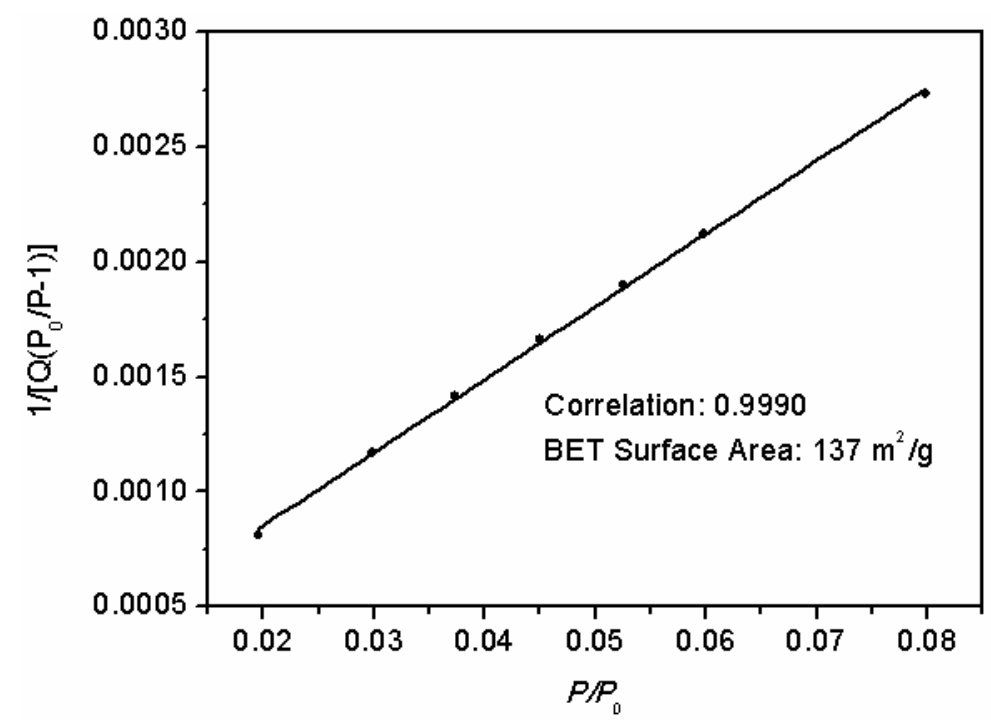

Figure S83. BET surface area plot for LZU-567 calculated from the adsorption isotherm. 


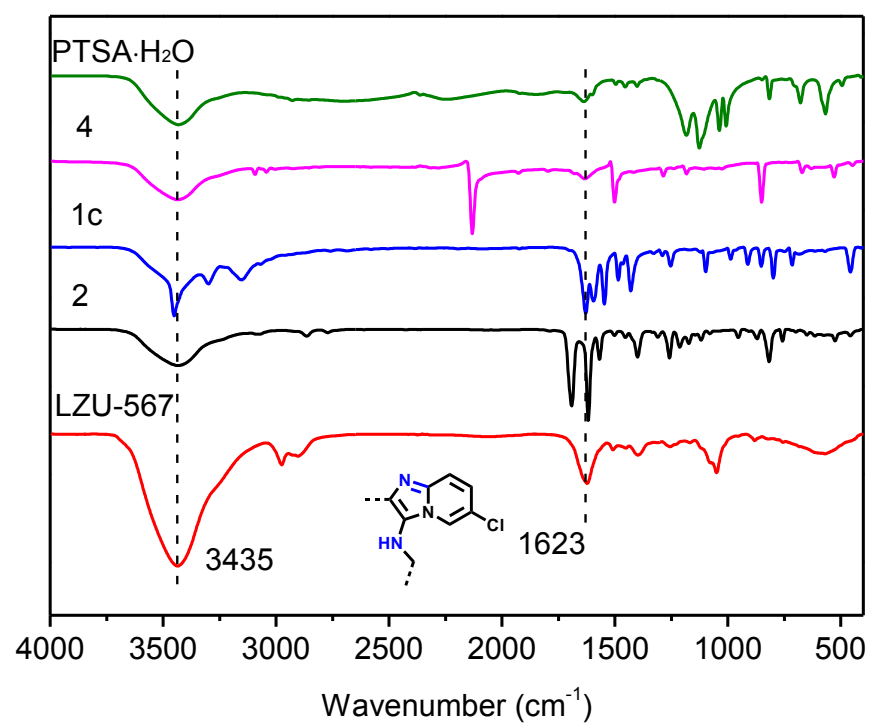

Figure S84. FT-IR spectra of the LZU-567 (red), the monomer 2 (black), monomer 1c (blue), monomer 4 (purple), and PTSA $\cdot \mathrm{H}_{2} \mathrm{O}$ (as the catalyst, green). The FT-IR spectrum of LZU-567 (red) shows stretches at $1623 \mathrm{~cm}^{-1}$, indicating the formation of the pyrimodazole ring.

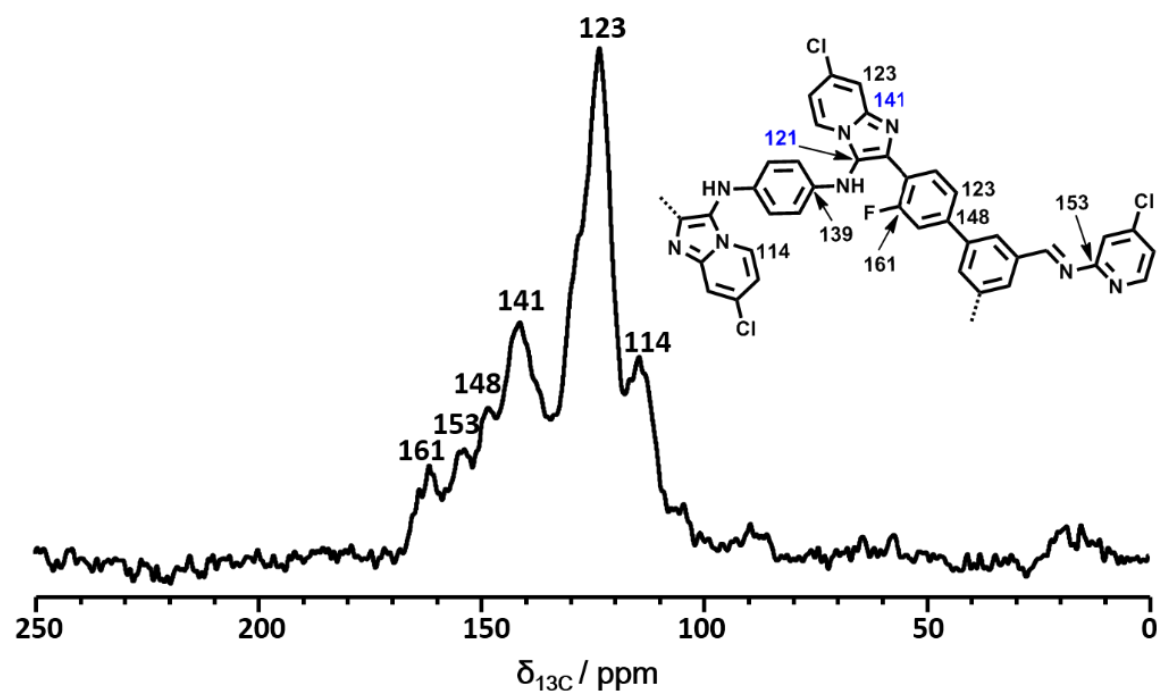

Figure S85. ${ }^{13} \mathrm{C}$ CP/MAS NMR spectra of LZU-567. The assignments of ${ }^{13} \mathrm{C}$ chemical shifts of LZU-567 were indicated in the chemical structure. 


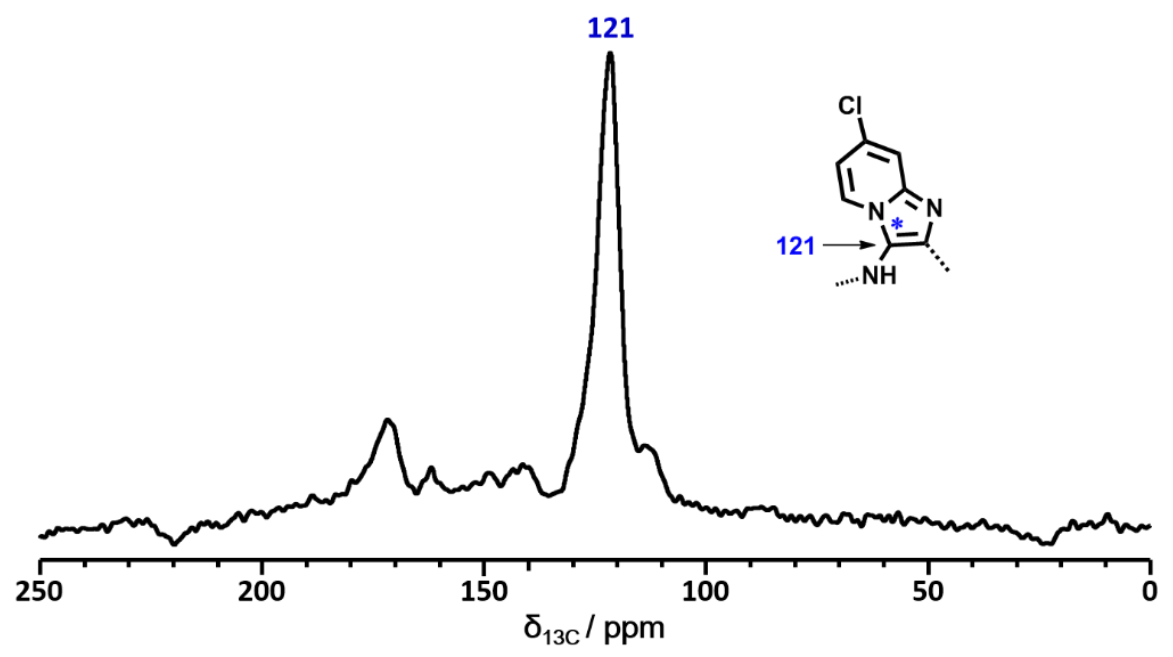

Figure S86. ${ }^{13} \mathrm{C}$ CP/MAS NMR spectra of ${ }^{13} \mathrm{C}$-labeled LZU-567. The ${ }^{13} \mathrm{C}$-labeled LZU-567 was made by ${ }^{13} \mathrm{C}$ labeled 1,4 -diisocyanobenzene $\left(-\mathrm{N} \equiv{ }^{13} \mathrm{C}\right)$. The presence of the peak at $121 \mathrm{ppm}$ indicates the formation of pyrimidazole ring with the ${ }^{13} \mathrm{C}$-labeled atom as *.

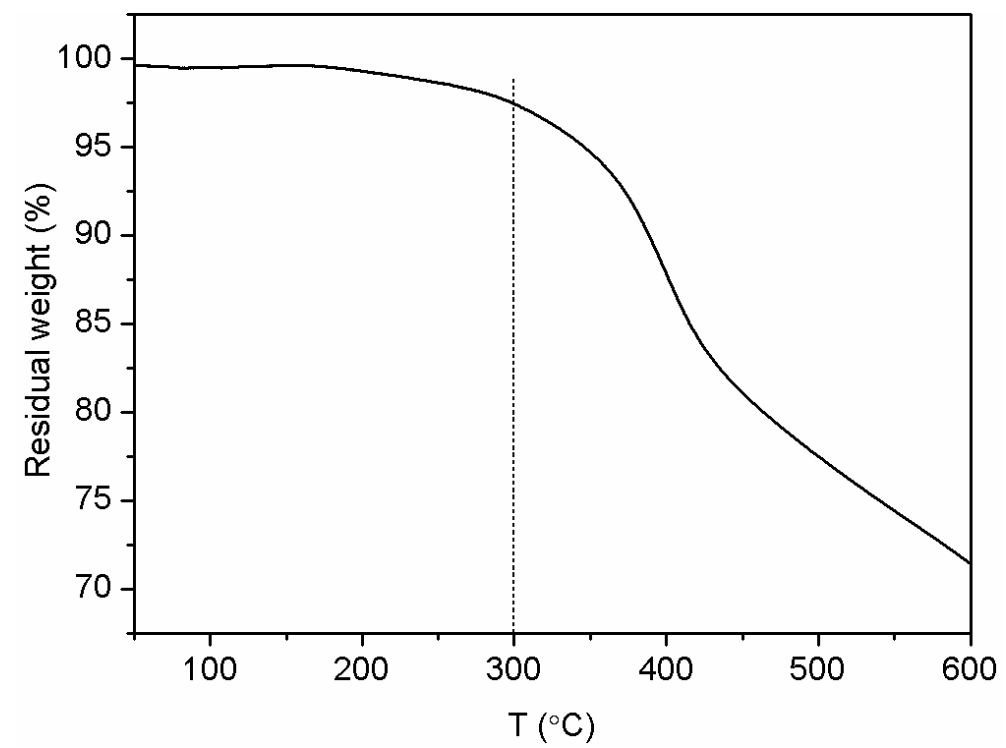

Figure S87. TGA data of LZU-567, indicating that LZU-567 is thermally stable up to $300^{\circ} \mathrm{C}$. 

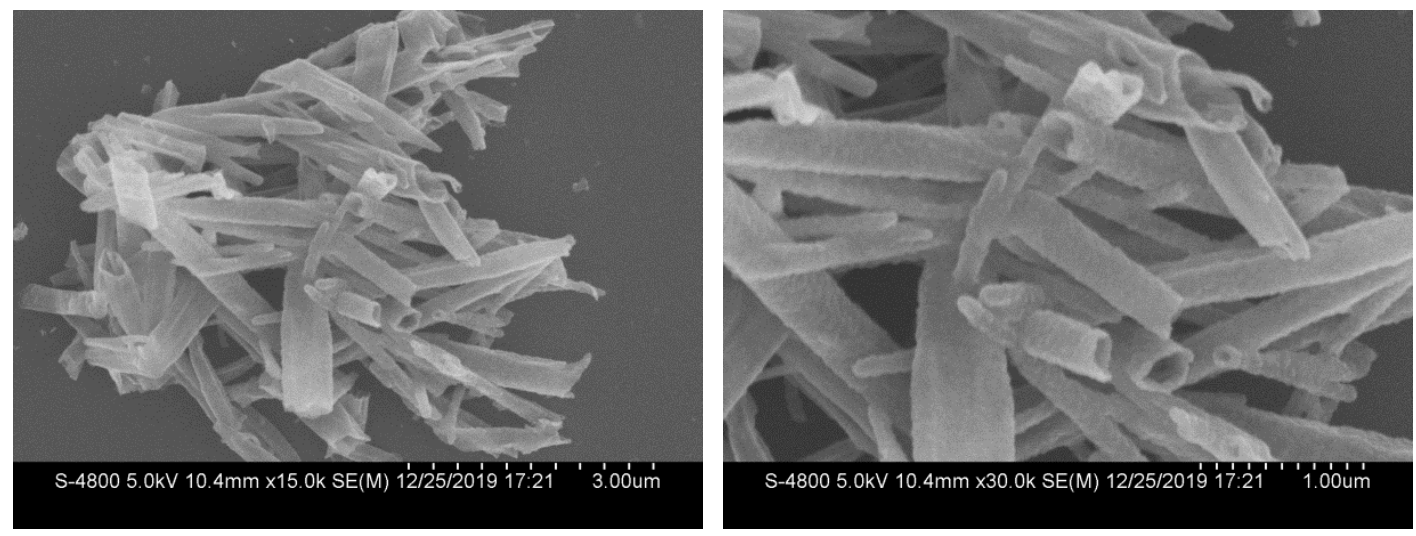

Figure S88. SEM images of LZU-567, showing that the obtained material possessed the uniform rod morphology.
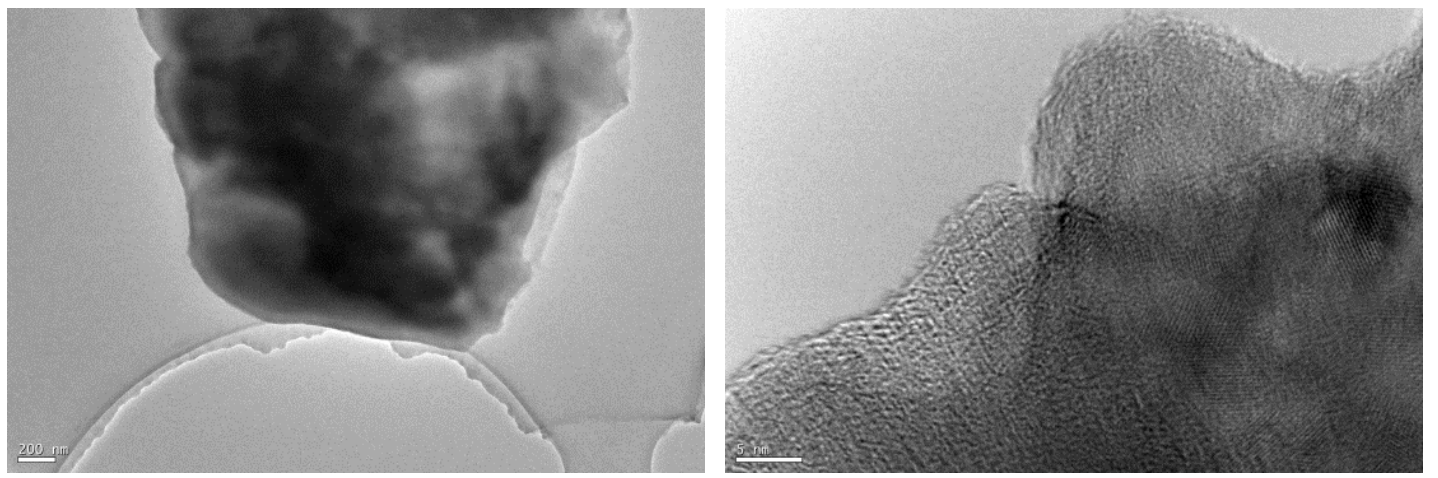

Figure S89. TEM images of LZU-567. 
The structural modeling of LZU-567 is similar to that of LZU-565. The Pawley refined lattice parameters were determined as: $a=b=34.722( \pm 0.416) \AA$ and $c=$ $4.319( \pm 0.052) \AA$ A. $R \mathrm{wp}$ and $R \mathrm{p}$ values converged to $8.39 \%$ and $6.24 \%$, respectively. Comparison of the observed and the simulated PXRD patterns (Figure S90) suggested that the preferable structure of LZU-567 is the eclipsed arrangement.

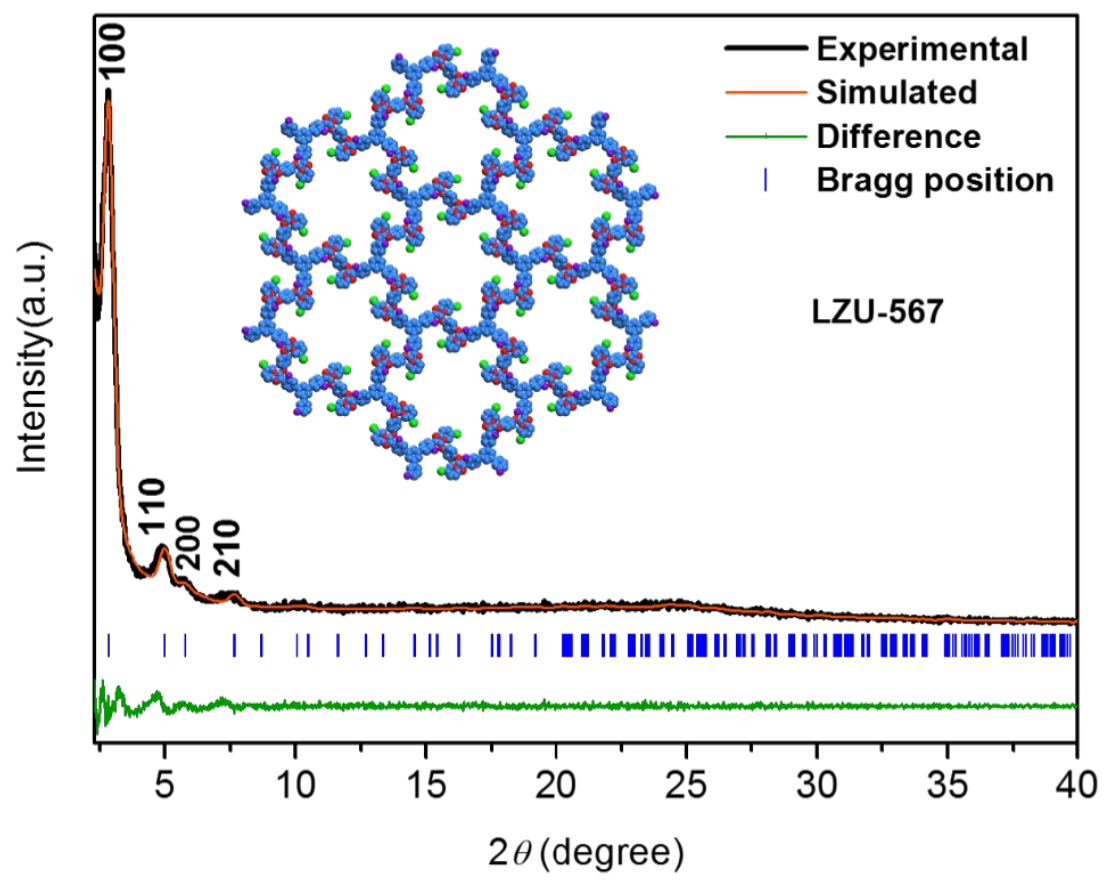

Figure S90. Indexed PXRD pattern and Pawley-refined profile of LZU-567. Inset: Structure of LZU-567 simulated with the eclipsed stacking model. C: blue, N: red, F: purple, $\mathrm{Cl}$ : green and $\mathrm{H}$ atoms are omitted for clarity. 


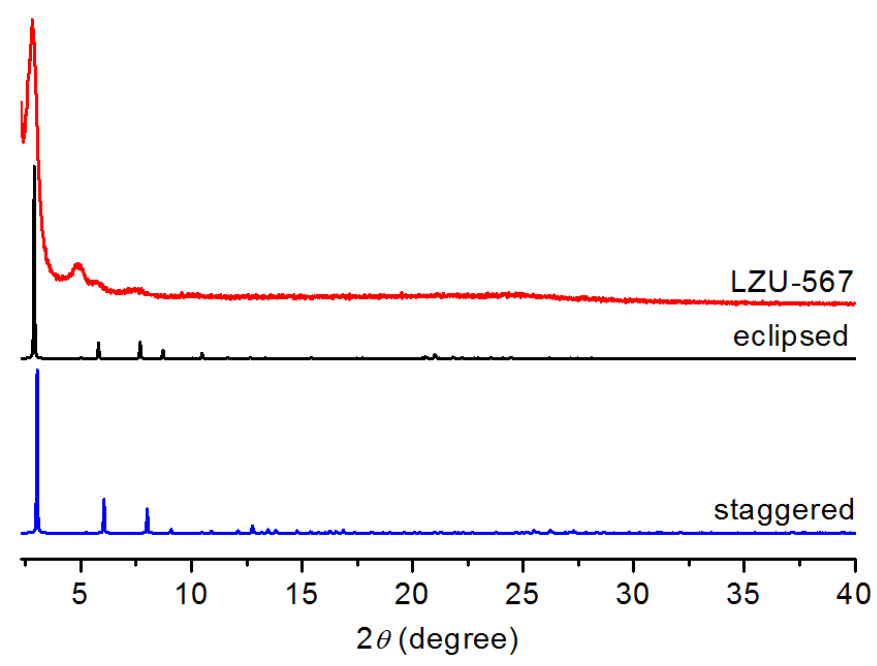

Figure S91. PXRD patterns of LZU-567: observed (red) and calculated with the eclipsed (black)/staggered (blue) stacking models. Comparison of the observed and the simulated PXRD patterns suggests that the preferable structure of LZU-567 is the eclipsed arrangement.

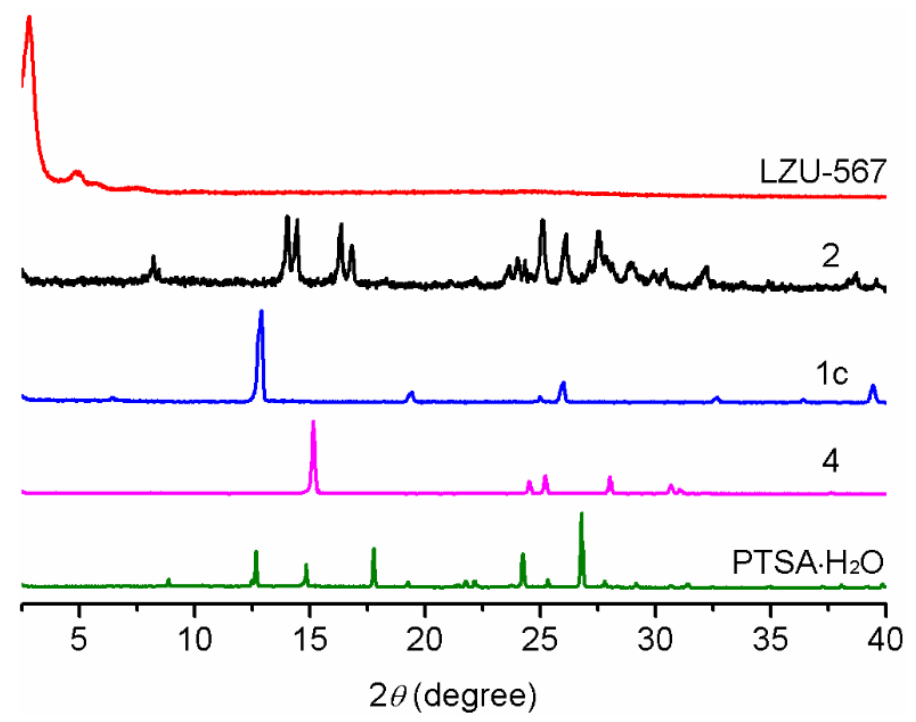

Figure S92. PXRD patterns of LZU-567 (red), the monomer 2 (black), the monomer $1 c$ (blue), the monomer 4 (purple) and PTSA $\mathrm{H}_{2} \mathrm{O}$ (as the catalyst, green). No diffraction peaks from 1c, 2, 4, and PTSA $\cdot \mathrm{H}_{2} \mathrm{O}$ could be observed in the PXRD pattern of LZU-567, indicating the formation of new crystalline structure. 
Table S7. Fractional atomic coordinates for the unit cell of LZU-567.

\begin{tabular}{|c|c|c|c|c|c|c|c|}
\hline \multicolumn{8}{|c|}{$\begin{array}{c}\text { Space group: } P 3 \\
a=b=35.085 \AA, c=4.351 \AA, \alpha=\beta=90^{\circ}, \gamma=120^{\circ}\end{array}$} \\
\hline Atom & $\mathbf{X}(\AA)$ & $\mathbf{Y}(\AA)$ & $\mathbf{Z}(\AA)$ & Atom & $\mathbf{X}(\AA ̊ \cap)$ & $\mathbf{Y}(\AA)$ & $\mathbf{Z}(\AA)$ \\
\hline $\mathrm{C} 1$ & 2.04021 & 0.0422 & -0.75953 & $\mathrm{C} 34$ & 2.31953 & 0.21029 & -0.42569 \\
\hline $\mathrm{C} 2$ & 1.99957 & 0.04061 & -0.76067 & N35 & 2.40341 & 0.17643 & -0.28437 \\
\hline $\mathrm{C} 3$ & 2.08198 & 0.085 & -0.74896 & $\mathrm{C} 36$ & 2.40994 & 0.13907 & -0.24825 \\
\hline $\mathrm{C} 4$ & 2.11764 & 0.08955 & \begin{tabular}{|l}
-0.57349 \\
\end{tabular} & N37 & 2.37863 & 0.09592 & -0.23845 \\
\hline $\mathrm{C} 5$ & 2.15712 & 0.12963 & -0.563 & C38 & 2.40105 & 0.07399 & -0.22234 \\
\hline C6 & 2.56567 & 0.5652 & -0.72694 & N39 & 2.44504 & 0.1004 & -0.2138 \\
\hline $\mathrm{C} 7$ & 2.12586 & 0.56192 & -0.89835 & $\mathrm{C} 40$ & 2.33383 & 0.0748 & -0.22382 \\
\hline $\mathrm{C} 8$ & 2.08655 & 0.12567 & -0.91152 & $\mathrm{C} 41$ & 2.3103 & 0.02873 & -0.20731 \\
\hline $\mathrm{C} 9$ & 2.20308 & 0.20906 & -0.72177 & $\mathrm{C} 42$ & 2.33323 & 0.00545 & -0.20076 \\
\hline $\mathrm{C} 10$ & 2.2458 & 0.2563 & \begin{tabular}{|l}
-0.74208 \\
\end{tabular} & $\mathrm{C} 43$ & 2.37931 & 0.02821 & -0.2059 \\
\hline N11 & 2.27318 & 0.26005 & -0.7706 & F44 & 2.47395 & 0.21455 & 0.18648 \\
\hline $\mathrm{C} 12$ & 2.24711 & 0.27801 & -0.75505 & $\mathrm{H} 45$ & 1.99847 & 0.07089 & -0.75832 \\
\hline $\mathrm{N} 13$ & 2.20398 & 0.24809 & -0.7279 & H46 & 2.11472 & 0.06232 & -0.43809 \\
\hline N14 & 2.25727 & 0.18282 & -0.79521 & $\mathrm{H} 47$ & 2.12864 & 0.18953 & -1.0284 \\
\hline $\mathrm{C} 15$ & 2.31703 & 0.28419 & -0.83222 & $\mathrm{H} 48$ & 2.06004 & 0.11913 & -1.05366 \\
\hline $\mathrm{C} 16$ & 2.33617 & 0.32987 & -0.866 & H49 & 2.23495 & 0.15539 & -0.92133 \\
\hline $\mathrm{C} 17$ & 2.3097 & 0.34937 & -0.84058 & $\mathrm{Cl} 50$ & 2.39252 & 0.36226 & -0.94556 \\
\hline $\mathrm{C} 18$ & 2.26439 & 0.32322 & -0.78654 & H51 & 2.32409 & 0.38458 & -0.86803 \\
\hline F19 & 2.19016 & 0.13282 & -0.3841 & H52 & 2.24344 & 0.33766 & -0.77536 \\
\hline $\mathrm{C} 20$ & 2.62445 & 0.29556 & \begin{tabular}{|l}
-0.19862 \\
\end{tabular} & H53 & 2.65884 & 0.25902 & -0.19862 \\
\hline $\mathrm{C} 21$ & 2.66225 & 0.29146 & -0.19849 & H54 & 2.55284 & 0.28083 & 0.13914 \\
\hline $\mathrm{C} 22$ & 2.57999 & 0.25586 & -0.20012 & H55 & 2.52259 & 0.15509 & -0.53802 \\
\hline $\mathrm{C} 23$ & 2.54628 & 0.254 & -0.01519 & H56 & 2.59623 & 0.21997 & -0.5309 \\
\hline $\mathrm{C} 24$ & 2.5043 & 0.25664 & -0.05674 & H57 & 2.28394 & 0.12615 & -0.93687 \\
\hline $\mathrm{C} 25$ & 2.49486 & 0.18118 & -0.21273 & H58 & 2.37571 & 0.23206 & -0.13099 \\
\hline $\mathrm{C} 26$ & 2.52889 & 0.18243 & -0.38966 & H59 & 2.42992 & 0.20754 & -0.23727 \\
\hline $\mathrm{C} 27$ & 2.57101 & 0.21942 & -0.38435 & $\mathrm{Cl} 60$ & 2.25266 & 0.0005 & -0.18836 \\
\hline $\mathrm{C} 28$ & 2.45075 & 0.14145 & -0.22389 & H61 & 2.3154 & -0.03012 & -0.18663 \\
\hline $\mathrm{C} 29$ & 2.29374 & 0.18115 & -0.65848 & H62 & 2.39742 & 0.01075 & -0.19382 \\
\hline $\mathrm{C} 30$ & 2.30374 & 0.14921 & -0.75958 & H63 & 0.31172 & 0.23422 & 0.66372 \\
\hline $\mathrm{C} 31$ & 2.3403 & 0.14809 & -0.64337 & H64 & 0.337 & 0.26895 & 0.14098 \\
\hline $\mathrm{C} 32$ & 2.36571 & 0.17683 & -0.40898 & H65 & 0.77631 & 0.68387 & 0.7858 \\
\hline $\mathrm{C} 33$ & 2.35587 & 0.20891 & -0.30813 & H66 & 0.77592 & 0.65133 & 0.26775 \\
\hline
\end{tabular}




\section{K. Synthesis and Characterization of LZU-568}

Synthesis of LZU-568

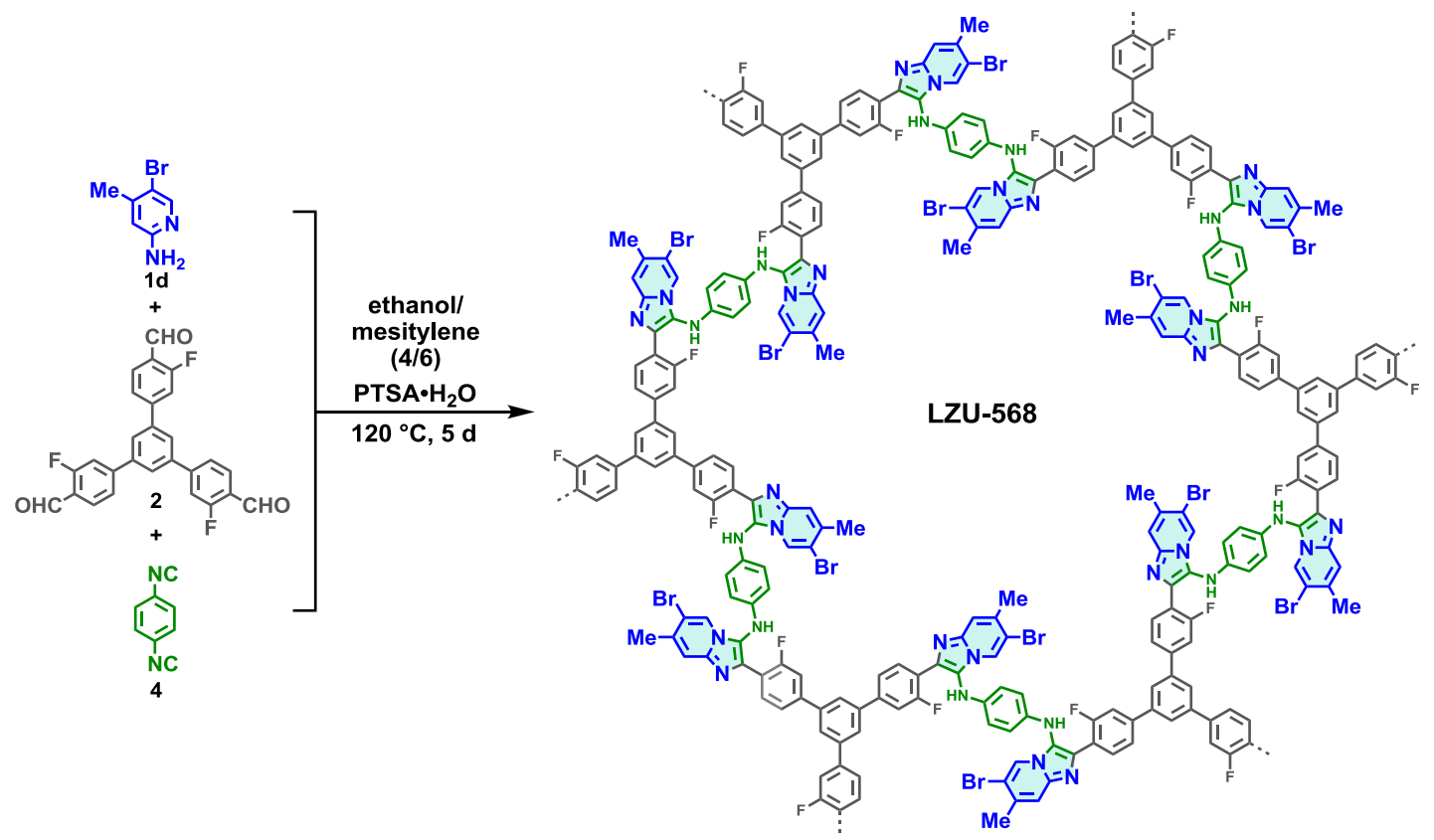

The synthetic procedure of LZU-568 was similar to that of LZU-561. Condensation of 2-amino-5-bromo-4-methylpyridine 1d (44 mg, $0.235 \mathrm{mmol}$ ),

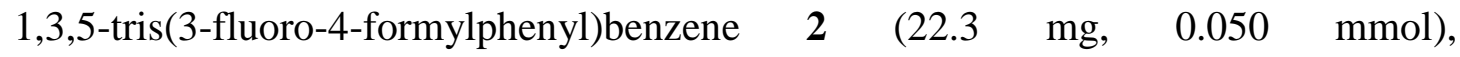
1,4-diisocyanobenzene $4(9.7 \mathrm{mg}, \quad 0.075 \mathrm{mmol})$ and $p$-toluenesulfonic acid monohydrate $(7.0 \mathrm{mg}, 0.037 \mathrm{mmol})$ yielded LZU-568 as an olive powder (40.5 mg, $71 \%$ yield). Anal. Cald for $\left(\mathrm{C}_{19} \mathrm{H}_{12} \mathrm{~N}_{3} \mathrm{FBr}\right)_{\mathrm{n}}$ : C 59.86; H 3.17; N 11.02, found: C 58.13; H 3.23; N 6.82. Characterization of LZU-568 was presented in the main text and in this SI.

The synthesis of ${ }^{13} \mathrm{C}$-labeled LZU-568 was similar to that of LZU-568. Condensation of 2-amino-5-bromo-4-methylpyridine 1d, 1,3,5-tris(3-fluoro-4-formyl phenyl)benzene 2 , and ${ }^{13} \mathrm{C}$-labeled 1,4-diisocyanobenzene $4 \quad\left(-\mathrm{N} \equiv{ }^{13} \mathrm{C}\right)$ yielded ${ }^{13}$ C-labeled LZU-568. 
Characterization of $L Z U-568$

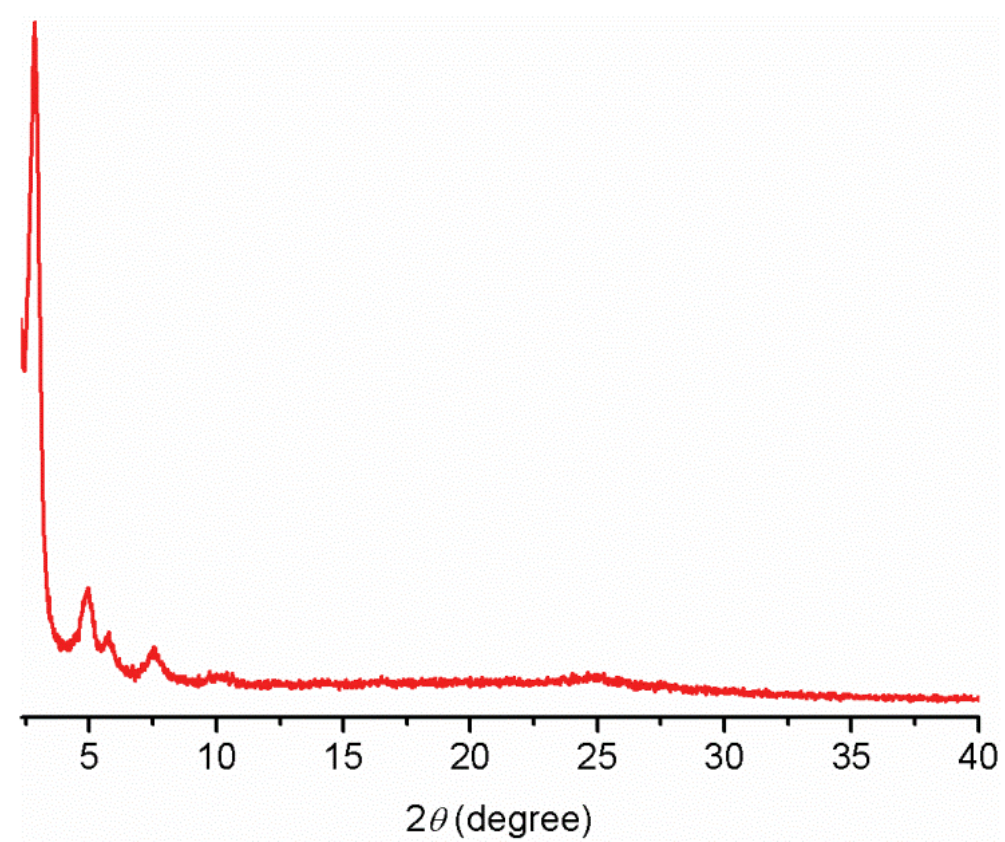

Figure S93. PXRD pattern of LZU-568 (ethanol/mesitylene (4/6), $120{ }^{\circ} \mathrm{C}, 5$ days).

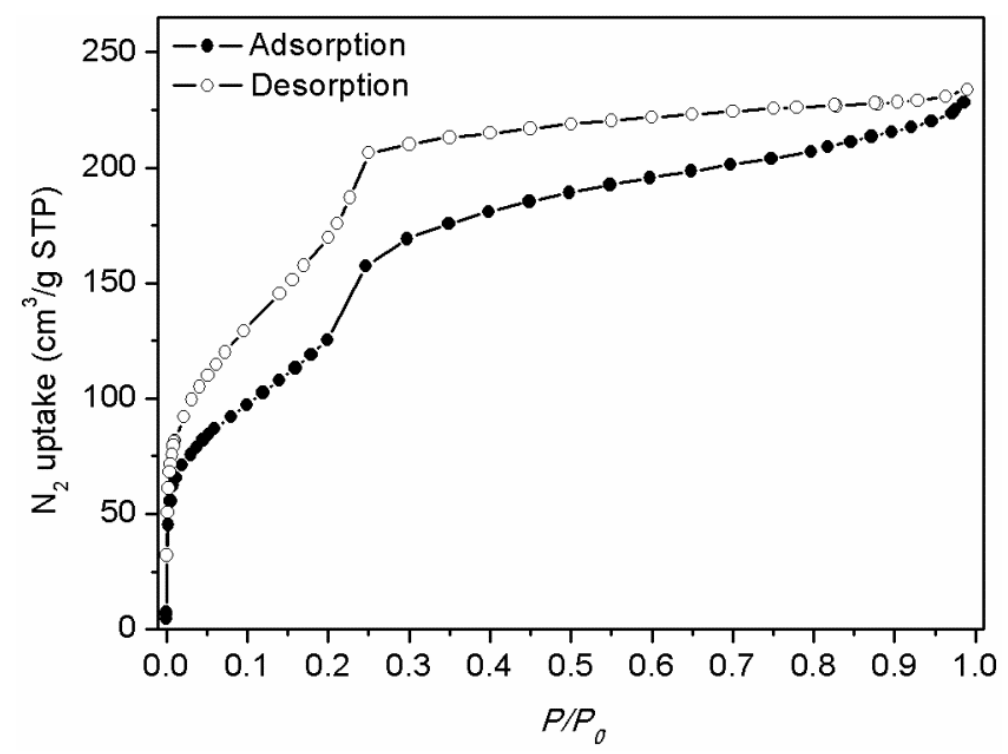

Figure S94. $\mathrm{N}_{2}$ adsorption and desorption isotherms of LZU-568. 


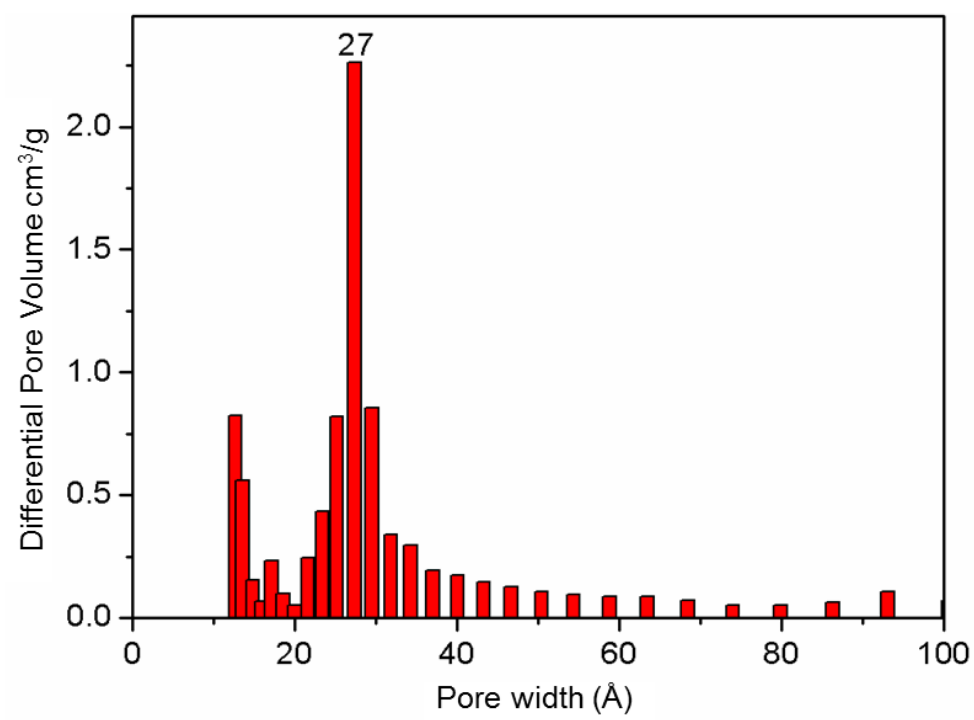

Figure S95. Pore size distribution of LZU-568 calculated by NLDFT (slit pores model).

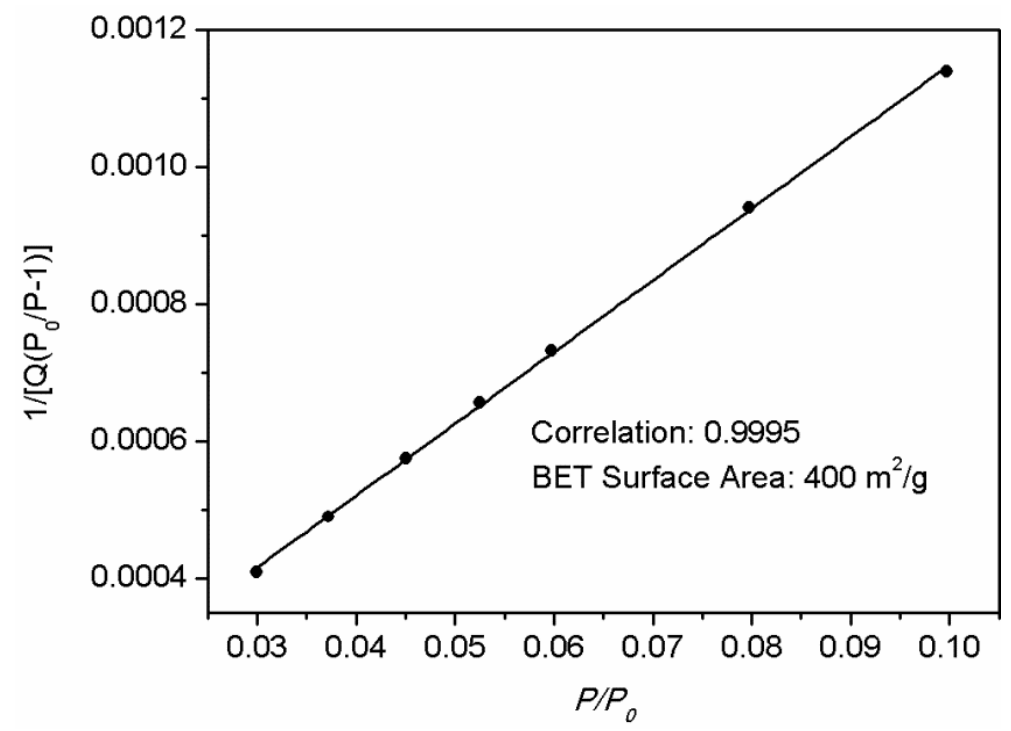

Figure S96. BET surface area plot for LZU-568 calculated from the adsorption isotherm. 


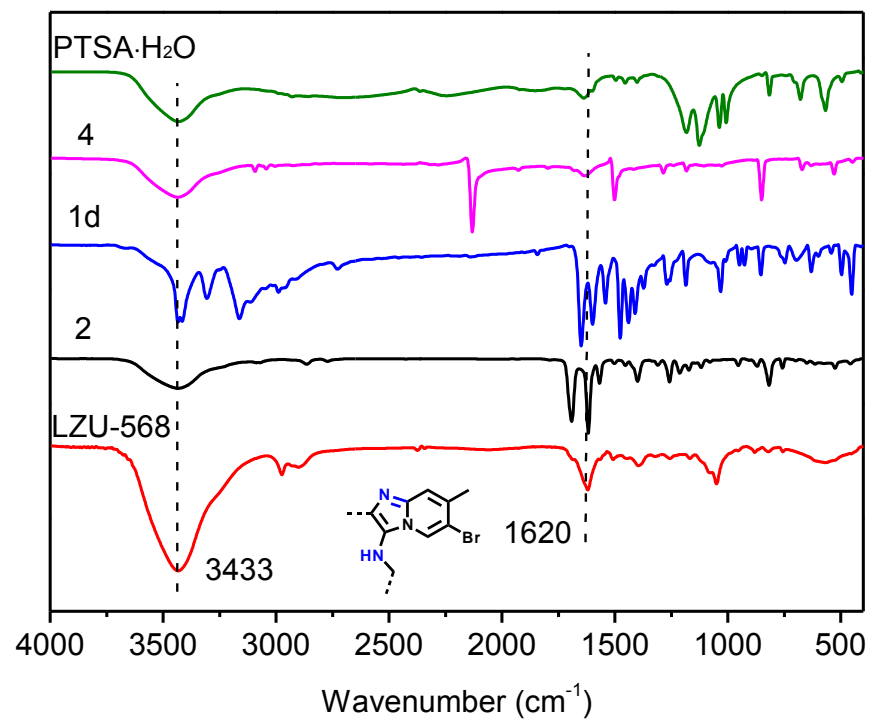

Figure S97. FT-IR spectra of the LZU-568 (red), the monomer 2 (black), monomer 1d (blue), monomer 4 (purple), and PTSA $\cdot \mathrm{H}_{2} \mathrm{O}$ (as the catalyst, green). The FT-IR spectrum of LZU-568 (red) shows stretches at $1620 \mathrm{~cm}^{-1}$, indicating the formation of the pyrimodazole ring.

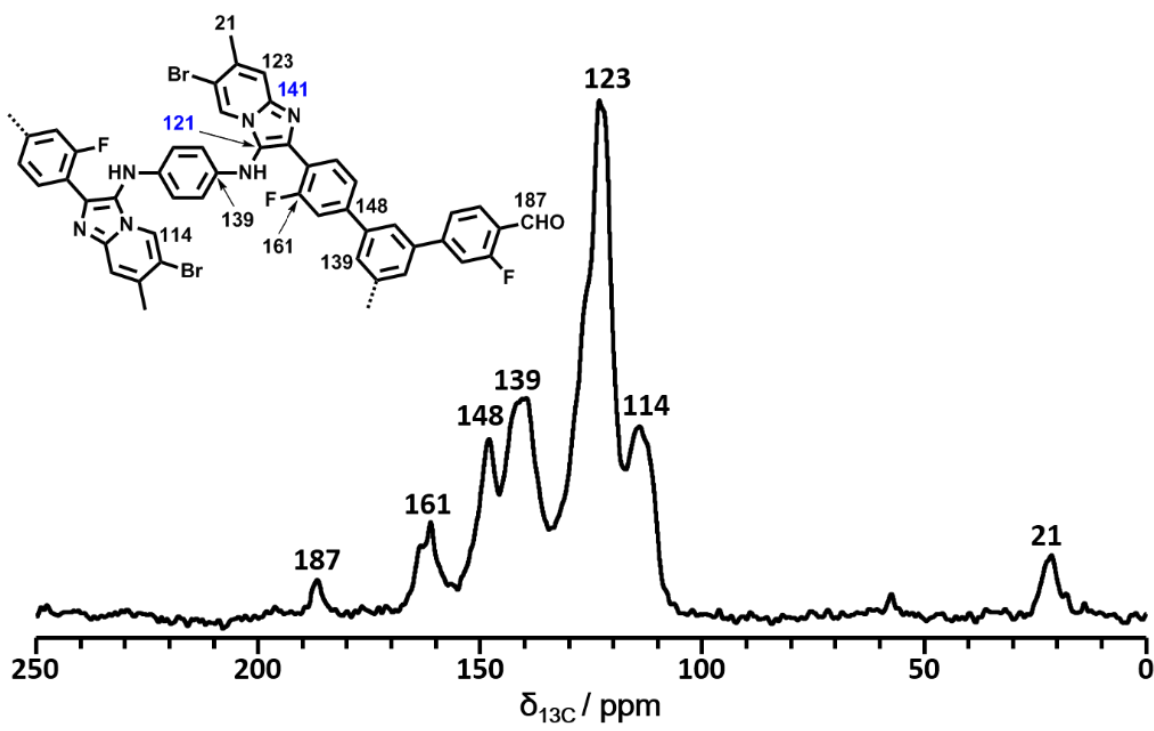

Figure S98. ${ }^{13} \mathrm{C}$ CP/MAS NMR spectra of LZU-568. The assignments of ${ }^{13} \mathrm{C}$ chemical shifts of LZU-568 were indicated in the chemical structure. 


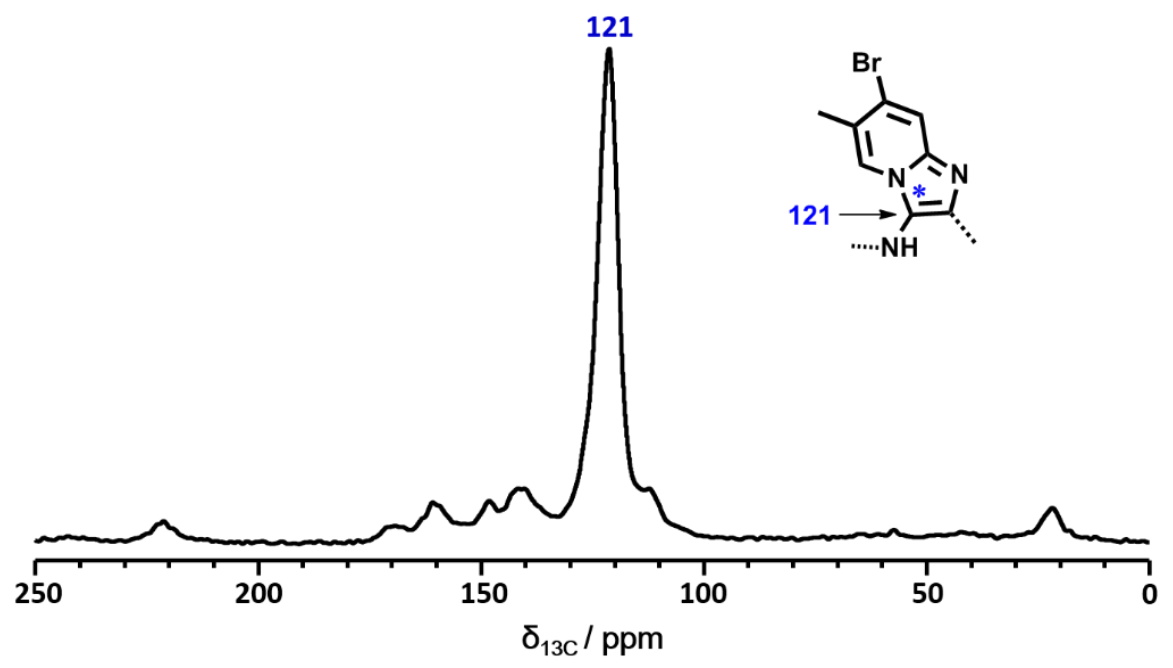

Figure S99. ${ }^{13} \mathrm{C}$ CP/MAS NMR spectra of ${ }^{13} \mathrm{C}$-labeled LZU-568. The ${ }^{13} \mathrm{C}$-labeled LZU-568 was made by ${ }^{13} \mathrm{C}$ labeled 1,4 -diisocyanobenzene $\left(-\mathrm{N} \equiv{ }^{13} \mathrm{C}\right)$. The presence of the peak at $121 \mathrm{ppm}$ indicates the formation of pyrimidazole ring with the 13C-labeled atom as *.

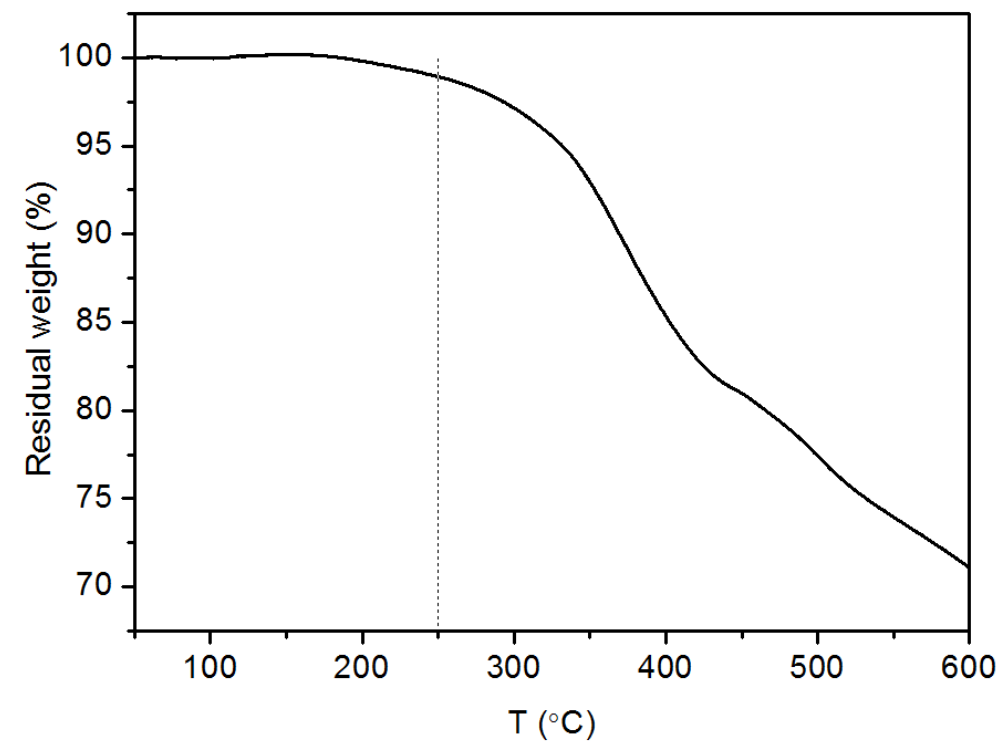

Figure S100. TGA data of LZU-568, indicating that LZU-568 is thermally stable up to $300^{\circ} \mathrm{C}$. 

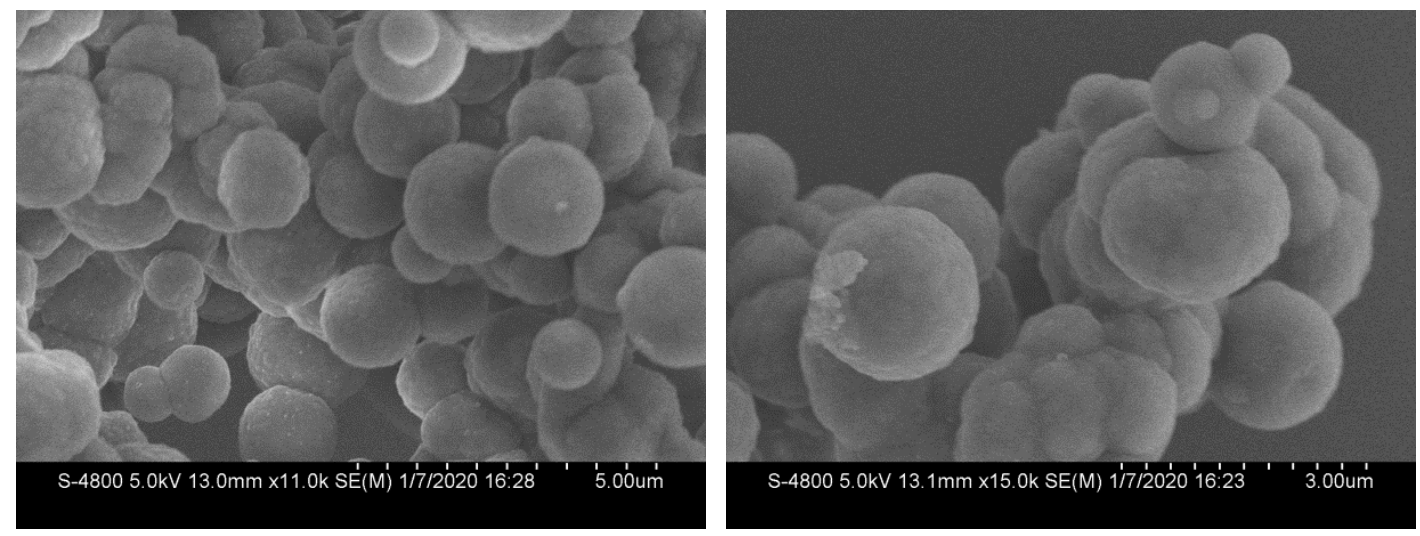

Figure S101. SEM images of LZU-568.
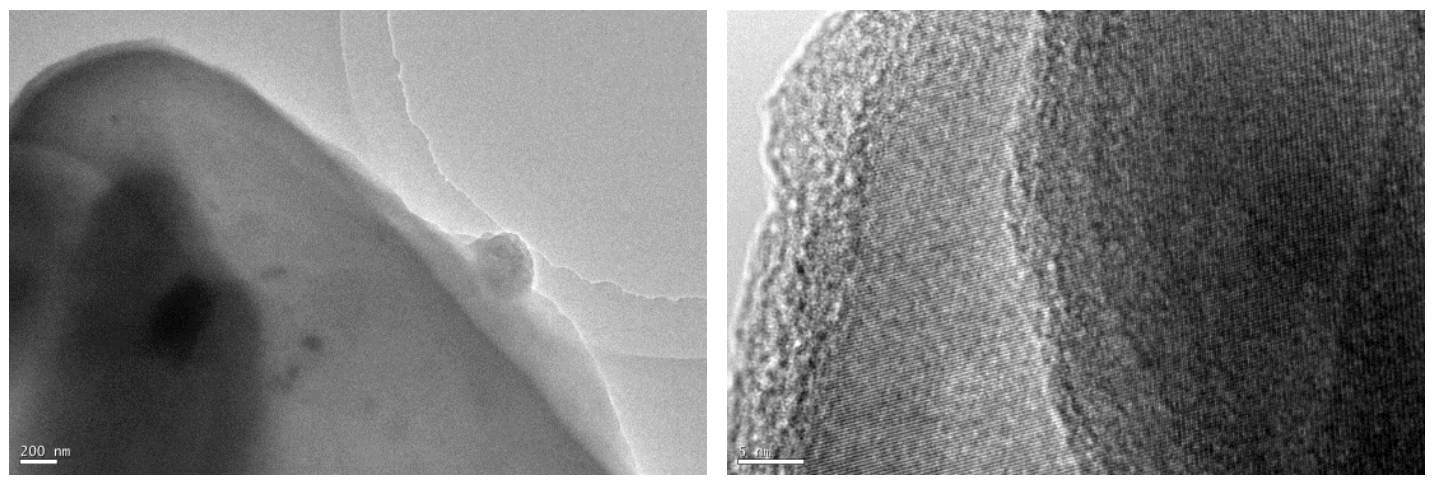

Figure S102.TEM images of LZU-568. 
The structural modeling of LZU-568 is similar to that of LZU-565. The Pawley refined lattice parameters were determined as: $a=b=34.775( \pm 0.372) \AA$ and $c=$ 4.060 ( \pm 0.044$) \AA$. $R \mathrm{wp}$ and $R \mathrm{p}$ values converged to $7.50 \%$ and $5.54 \%$, respectively. Comparison of the observed and the simulated PXRD patterns (Figure S103) suggests that the preferable structure of LZU-568 is the eclipsed arrangement.

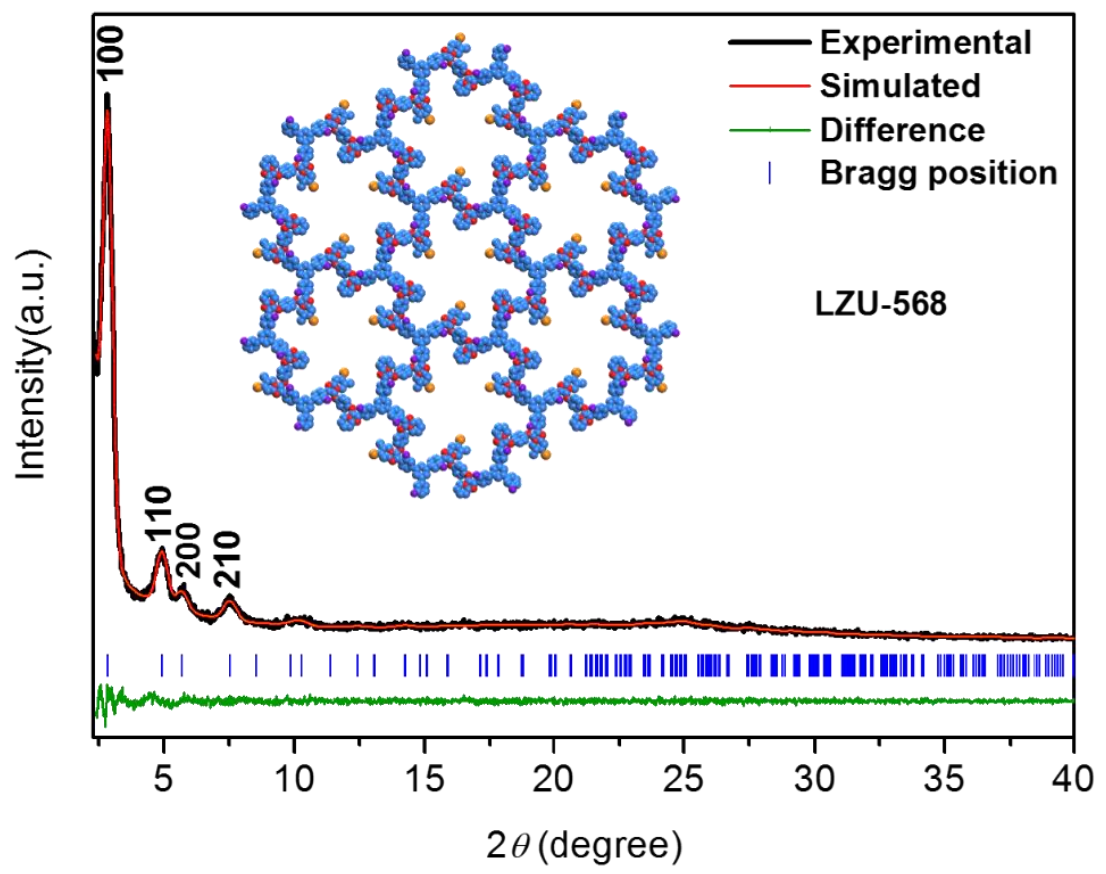

Figure S103. Indexed PXRD pattern and Pawley-refined profile of LZU-568. Inset: Structure of LZU-568 simulated with the eclipsed stacking model. C: blue, N: red, F: purple, Br: orange and $\mathrm{H}$ atoms are omitted for clarity. 


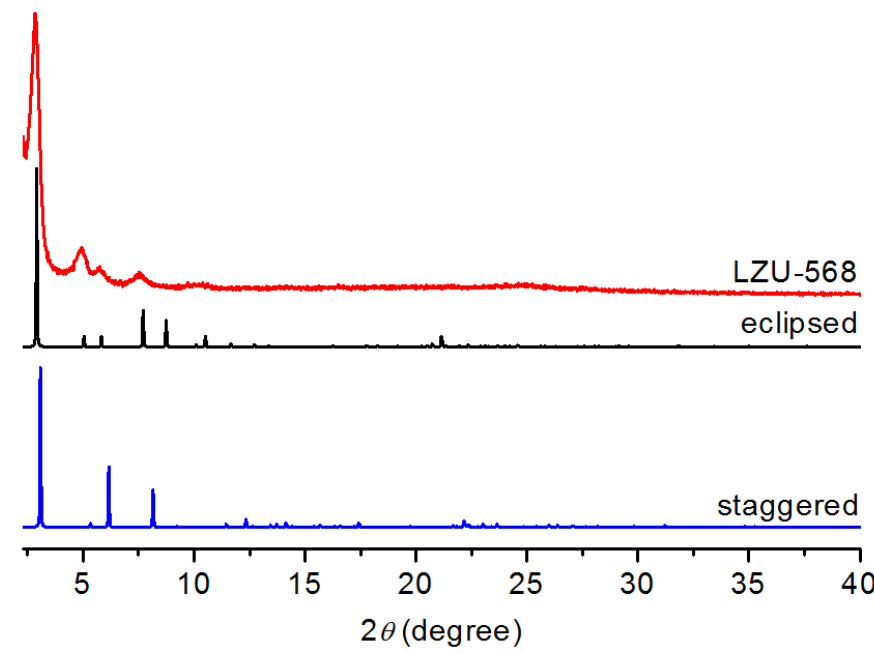

Figure S104. PXRD patterns of LZU-568: observed (red) and calculated with the eclipsed (black)/staggered (blue) stacking models. Comparison of the observed and the simulated PXRD patterns suggests that the preferable structure of LZU-568 is the eclipsed arrangement.

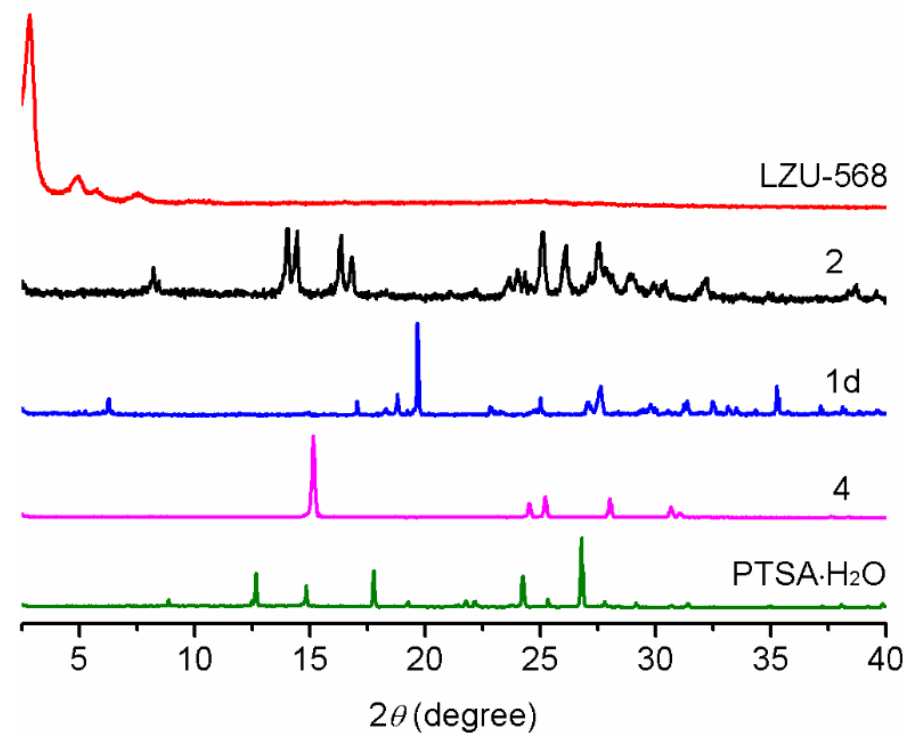

Figure S105. PXRD patterns of LZU-568 (red), the monomer 2 (black), the monomer 1d (blue), the monomer 4 (purple) and PTSA. $\mathrm{H}_{2} \mathrm{O}$ (as the catalyst, green). No diffraction peaks from 1d, 2, 4, and PTSA $\cdot \mathrm{H}_{2} \mathrm{O}$ could be observed in the PXRD pattern of LZU-568, indicating the formation of new crystalline structure. 
Table S8. Fractional atomic coordinates for the unit cell of LZU-568.

\begin{tabular}{|c|c|c|c|c|c|c|c|}
\hline \multicolumn{8}{|c|}{$\begin{array}{c}\text { Space group: } P 3 \\
a=b=35.149 \AA \text { }, c=4.350 \AA, \alpha=\beta=90^{\circ}, \gamma=120^{\circ}\end{array}$} \\
\hline Atom & $\mathbf{X}(\AA)$ & $\mathbf{Y}(\AA)$ & $\mathbf{Z}(\AA)$ & Atom & $\mathbf{X}(\AA)$ & $\mathbf{Y}(\AA)$ & $\mathbf{Z}(\AA)$ \\
\hline $\mathrm{C} 1$ & 2.04054 & 0.04176 & -0.74685 & $\mathrm{C} 36$ & 2.41141 & 0.13724 & -0.24668 \\
\hline $\mathrm{C} 2$ & 2.00032 & 0.04092 & -0.74763 & N37 & 2.38048 & 0.09405 & -0.23704 \\
\hline $\mathrm{C} 3$ & 2.08264 & 0.08412 & -0.73898 & C38 & 2.40327 & 0.07257 & -0.2212 \\
\hline $\mathrm{C} 4$ & 2.11818 & 0.08826 & -0.56474 & N39 & 2.44713 & .09931 & -0.21253 \\
\hline $\mathrm{C} 5$ & 2.15796 & 0.12795 & -0.55692 & $\mathrm{C} 40$ & 2.33573 & 0.07252 & -0.22248 \\
\hline C6 & 2.56293 & 0.56451 & -0.7225 & $\mathrm{C} 41$ & 2.31271 & 0.02654 & -0.20671 \\
\hline $\mathrm{C} 7$ & 2.12726 & 0.16061 & -0.89299 & $\mathrm{C} 42$ & 2.33602 & 0.00374 & -0.20044 \\
\hline $\mathrm{C} 8$ & 2.08766 & 0.12078 & -0.90341 & $\mathrm{C} 43$ & 2.38201 & 0.02689 & -0.20525 \\
\hline C9 & 2.20457 & 0.20702 & -0.7194 & F44 & 2.47464 & 0.21283 & 0.18838 \\
\hline $\mathrm{C} 10$ & 2.24704 & 0.21378 & -0.73975 & $\mathrm{H} 45$ & 1.99978 & 0.07143 & -0.74563 \\
\hline N11 & 2.27469 & 0.25738 & -0.77067 & $\mathrm{H} 46$ & 2.11494 & 0.06104 & -0.42817 \\
\hline $\mathrm{C} 12$ & 2.24905 & 0.27569 & -0.75692 & $\mathrm{H} 47$ & 2.13035 & 0.18821 & -1.0243 \\
\hline N13 & 2.20592 & 0.24618 & -0.72819 & $\mathrm{H} 48$ & 2.06125 & 0.11851 & -1.04484 \\
\hline N14 & 2.25806 & 0.17999 & -0.79053 & H49 & & 0.15249 & -0.91466 \\
\hline $\mathrm{C} 15$ & & & & & & 0.35352 & -0.94603 \\
\hline $\mathrm{C} 16$ & 2.33819 & 0.32673 & -0.8735 & Br51 & 2.33601 & 0.40862 & -0.90318 \\
\hline $\mathrm{C} 17$ & 2.31181 & 0.34662 & -0.8495 & H52 & 2.24575 & 0.33523 & -0.78227 \\
\hline $\mathrm{C} 18$ & 2.26661 & 0.32074 & -0.79235 & H53 & 2.65993 & 0.25961 & -0.19661 \\
\hline F19 & 2.19086 & 0.13082 & -0.37874 & H54 & 2.55302 & 0.27963 & 0.14132 \\
\hline $\mathrm{C} 20$ & 2.62478 & 0.29528 & -0.1966 & $1 J 5$ & 2.52442 & 0.15459 & -0.53596 \\
\hline $\mathrm{C} 21$ & 2.66286 & 0.29179 & -0.1965 & & 2.59752 & 0.21994 & -0.52868 \\
\hline $\mathrm{C} 22$ & 2.58067 & 0.25528 & -0.19796 & H57 & 2.28491 & 0.12355 & -0.93399 \\
\hline $\mathrm{C} 23$ & 2.54681 & 0.25295 & -0.01301 & H58 & 2.37645 & 0.22939 & -0.12827 \\
\hline $\mathrm{C} 24$ & 2.50515 & 0.21543 & -0.01473 & H59 & 2.43079 & 0.20543 & -0.23728 \\
\hline $\mathrm{C} 25$ & 2.49616 & 0.18006 & -0.21073 & H60 & 2.2772 & 0.00875 & -0.19549 \\
\hline $\mathrm{C} 26$ & 2.53036 & 0.18178 & -0.38754 & H61 & 2.31842 & -0.03175 & -0.1868 \\
\hline $\mathrm{C} 27$ & 2.57217 & 0.21904 & -0.38215 & H62 & 2.40041 & 0.00978 & -0.19341 \\
\hline $\mathrm{C} 28$ & 2.45236 & 0.14009 & -0.22234 & H63 & 0.31241 & 0.23129 & 0.66702 \\
\hline $\mathrm{C} 29$ & 2.29451 & 0.17832 & -0.65454 & H64 & 0.33778 & 0.26513 & 0.14192 \\
\hline $\mathrm{C} 30$ & 2.3046 & 0.14654 & -0.75626 & $\mathrm{H} 65$ & 0.77207 & 0.68239 & 0.78758 \\
\hline $\mathrm{C} 31$ & 2.3412 & 0.14555 & -0.64043 & H66 & 0.77254 & 0.65032 & 0.26986 \\
\hline $\mathrm{C} 32$ & 2.36656 & 0.1743 & -0.40616 & H67 & 0.39089 & 0.36998 & -0.17178 \\
\hline $\mathrm{C} 33$ & 2.35662 & 0.20621 & -0.30491 & H68 & 0.4019 & 0.33274 & 0.04234 \\
\hline $\mathrm{C} 34$ & 2.32024 & 0.20743 & -0.42188 & H69 & 0.40329 & 0.37874 & 0.23486 \\
\hline N35 & 2.40444 & 0.17425 & -0.28304 & & & & \\
\hline
\end{tabular}




\section{Stability Tests of LZU-563}

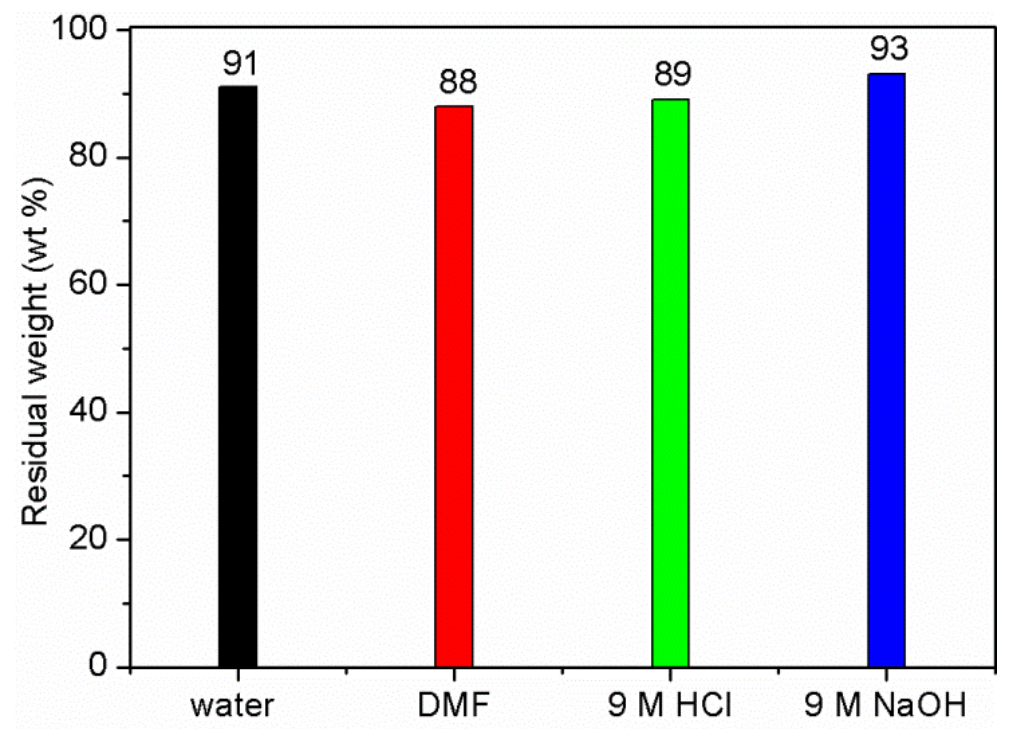

Figure S106. Residue weight percentage of LZU-563 after treatment in different solvents. The almost unchanged weights indicate that LZU-563 is stable after treatment under these conditions. 

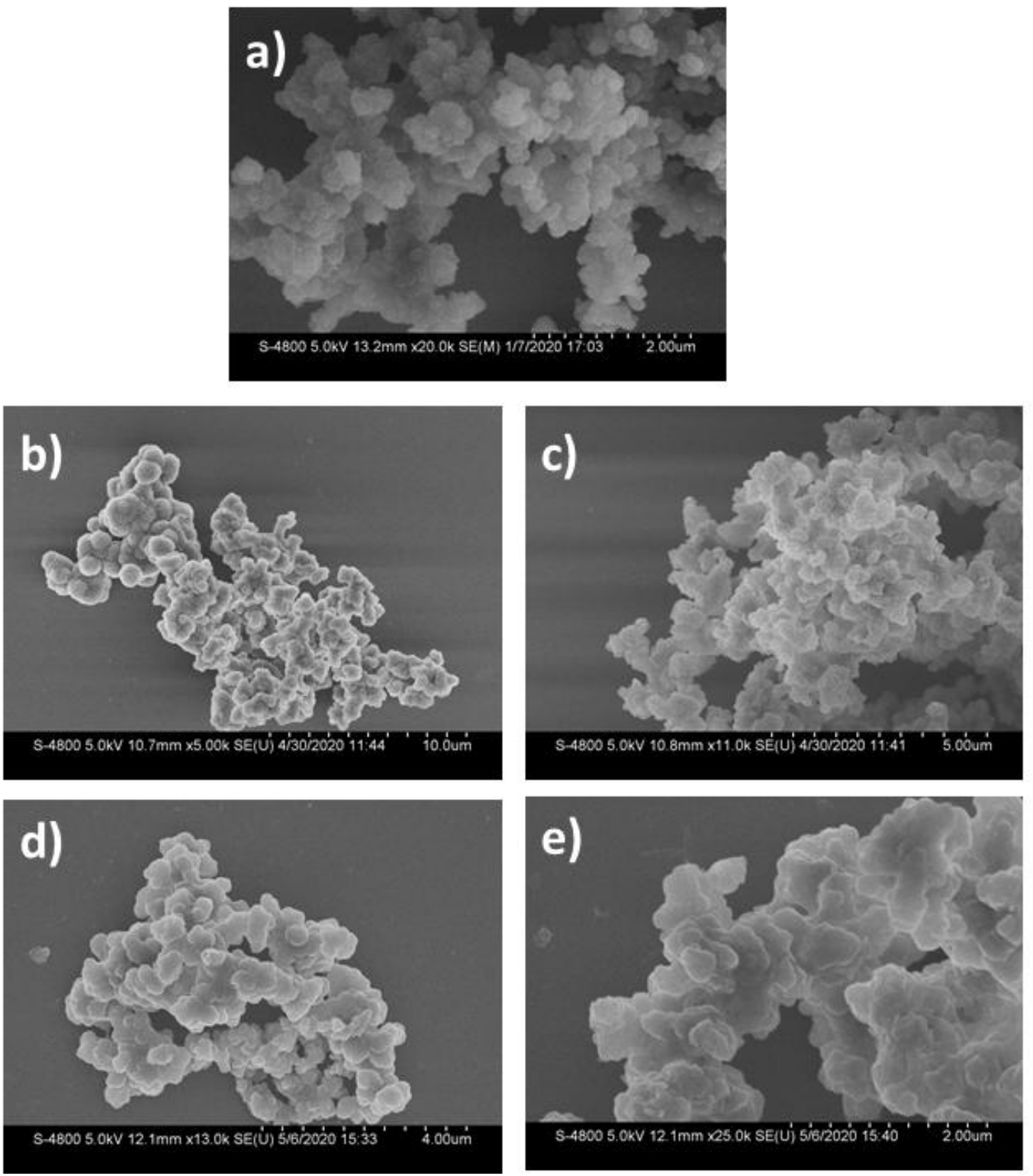

Figure S107. SEM images of LZU-563 before (a) and after treatment with water (b), DMF (c), $9 \mathrm{M} \mathrm{HCl}$ (d), $9 \mathrm{M} \mathrm{NaOH}$ (e). The almost unchanged morphologies indicate that LZU-563 is stable after treatment under these conditions. 


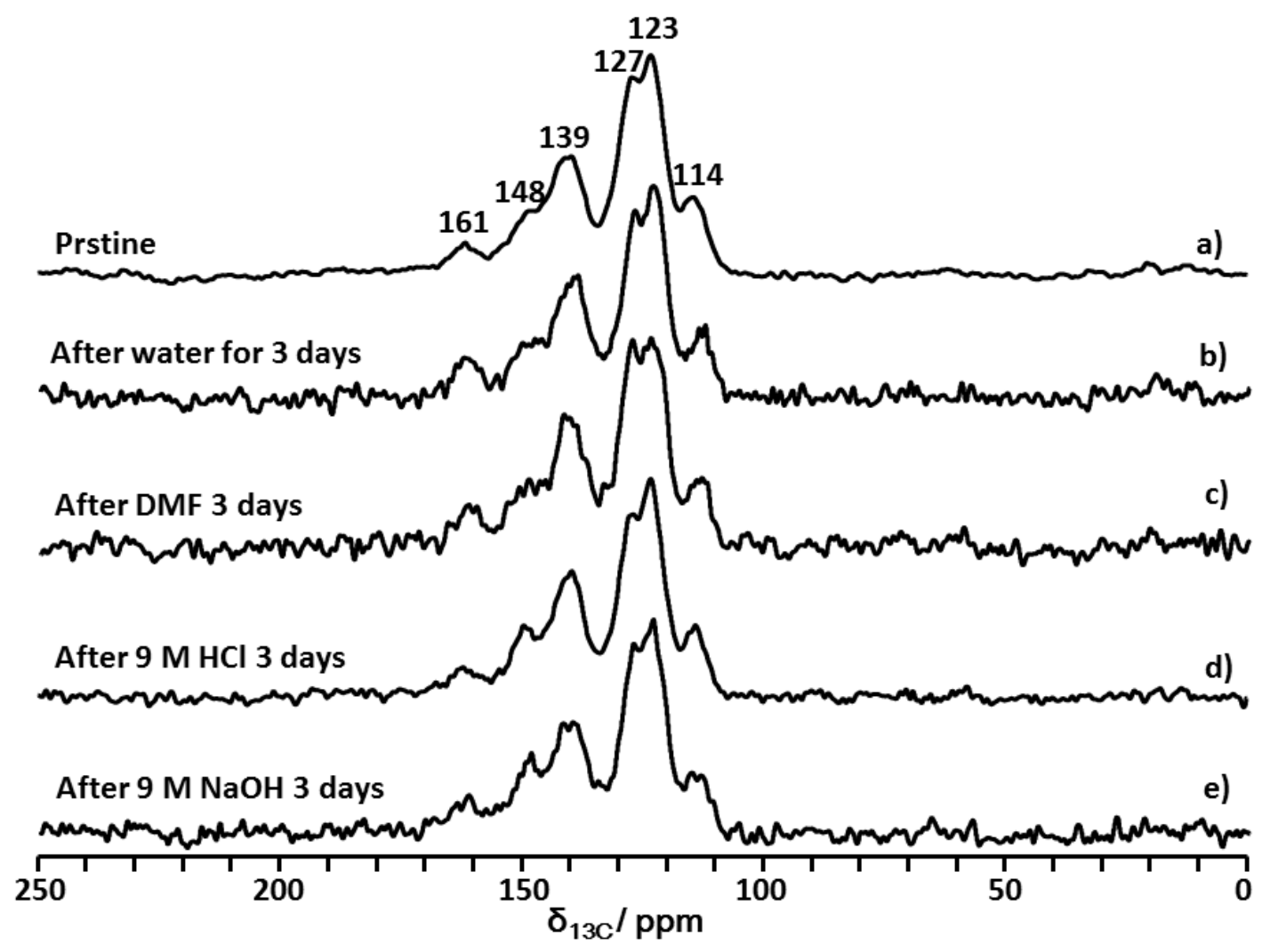

Figure S108. ${ }^{13} \mathrm{C}$ CP/MAS NMR spectra of LZU-563 before (a) and after treatment with water (b), DMF (c), $9 \mathrm{M} \mathrm{HCl}(\mathrm{d})$, and $9 \mathrm{M} \mathrm{NaOH}(\mathrm{e})$. The almost unchanged ${ }^{13} \mathrm{C}$ CP/MAS NMR spectra indicate that LZU-563 is stable after treatment under these conditions. 


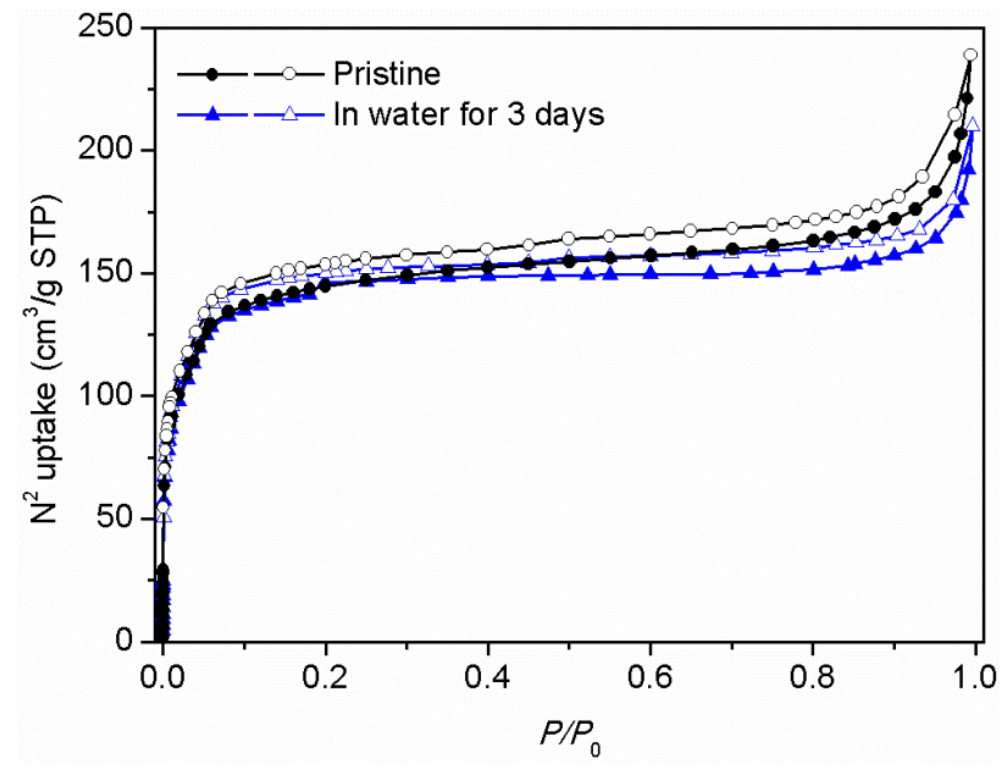

Figure S109. $\mathrm{N}_{2}$ adsorption (filled shapes) and desorption (open shapes) isotherms of LZU-563 before (black) and after treatment with water for 3 days (blue).

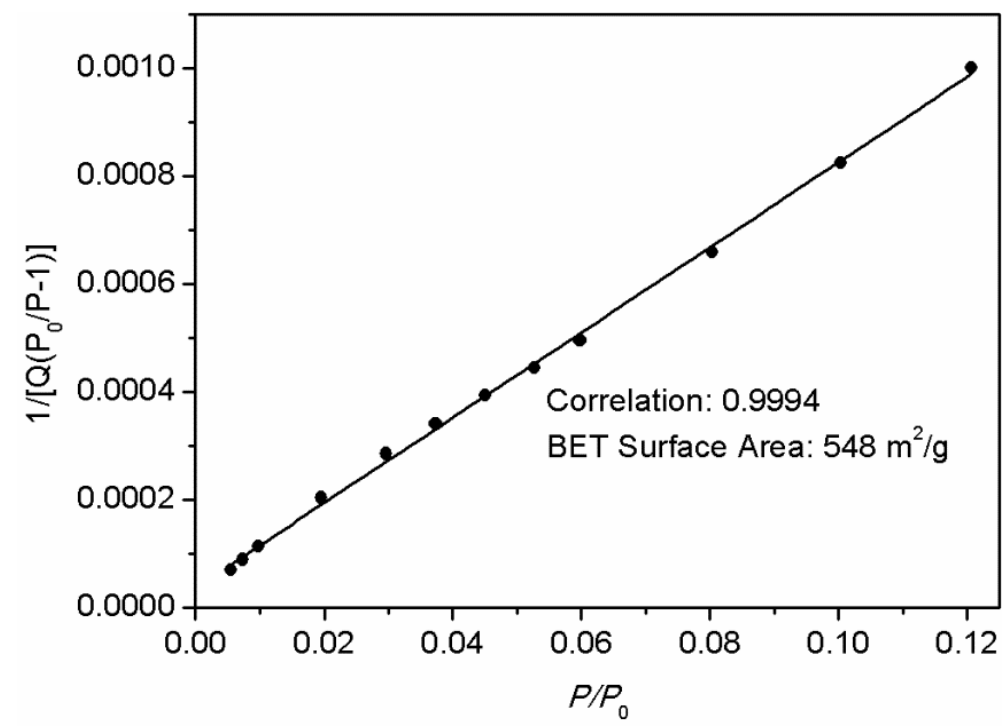

Figure S110. BET surface area plot for LZU-563 after treatment with water for 3 days. 


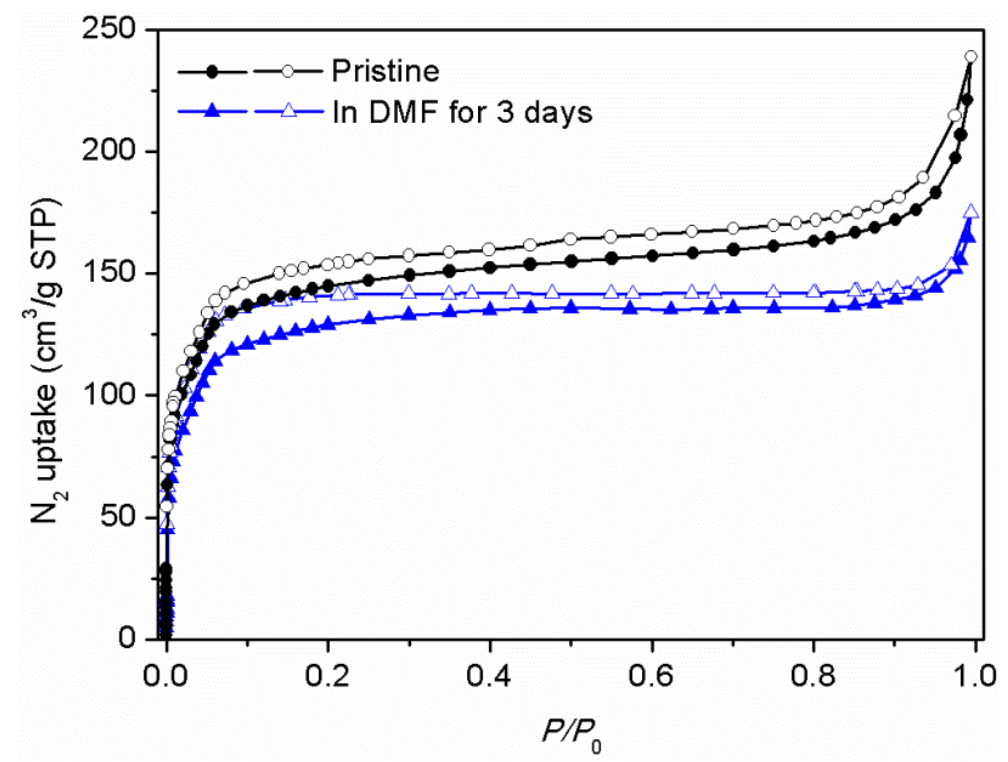

Figure S111. $\mathrm{N}_{2}$ adsorption (filled shapes) and desorption (open shapes) isotherms of LZU-563 before (black) and after treatment with DMF for 3 days (blue).

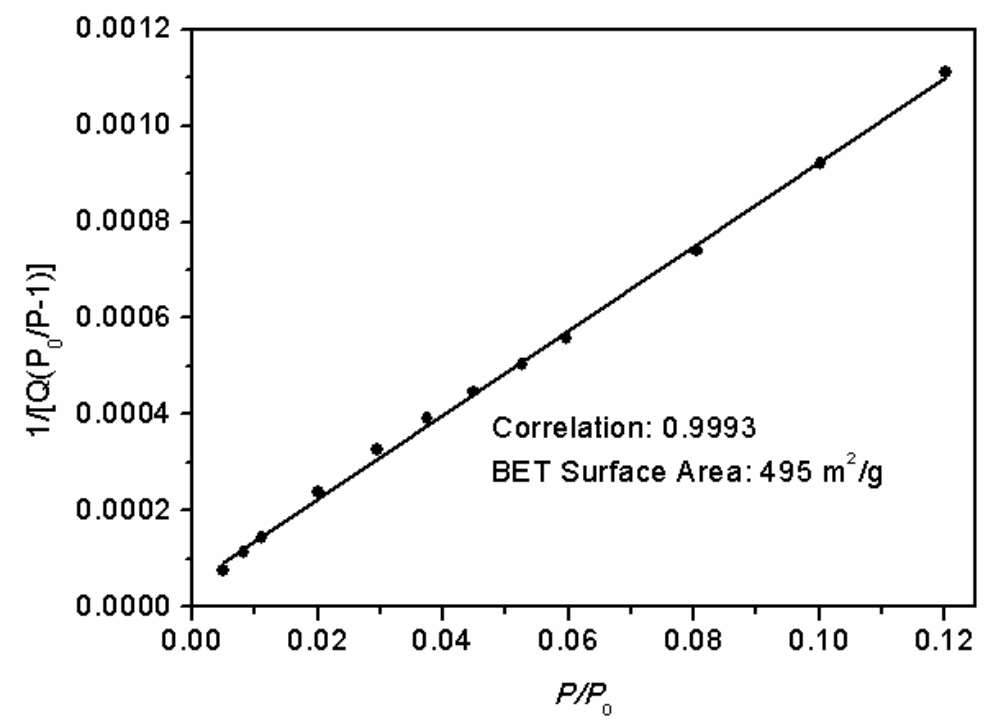

Figure S112. BET surface area plot for LZU-563 after treatment with DMF for 3 days. 


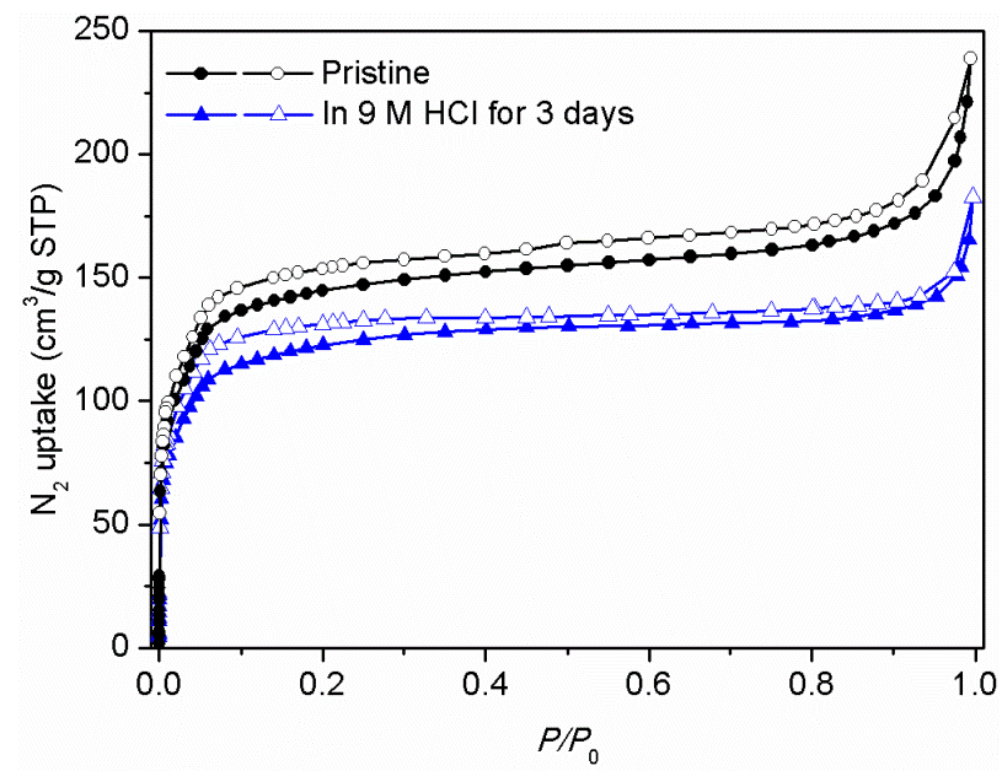

Figure S113. $\mathrm{N}_{2}$ adsorption (filled shapes) and desorption (open shapes) isotherms of LZU-563 before (black) and after treatment with $9 \mathrm{M} \mathrm{HCl}$ for 3 days (blue).

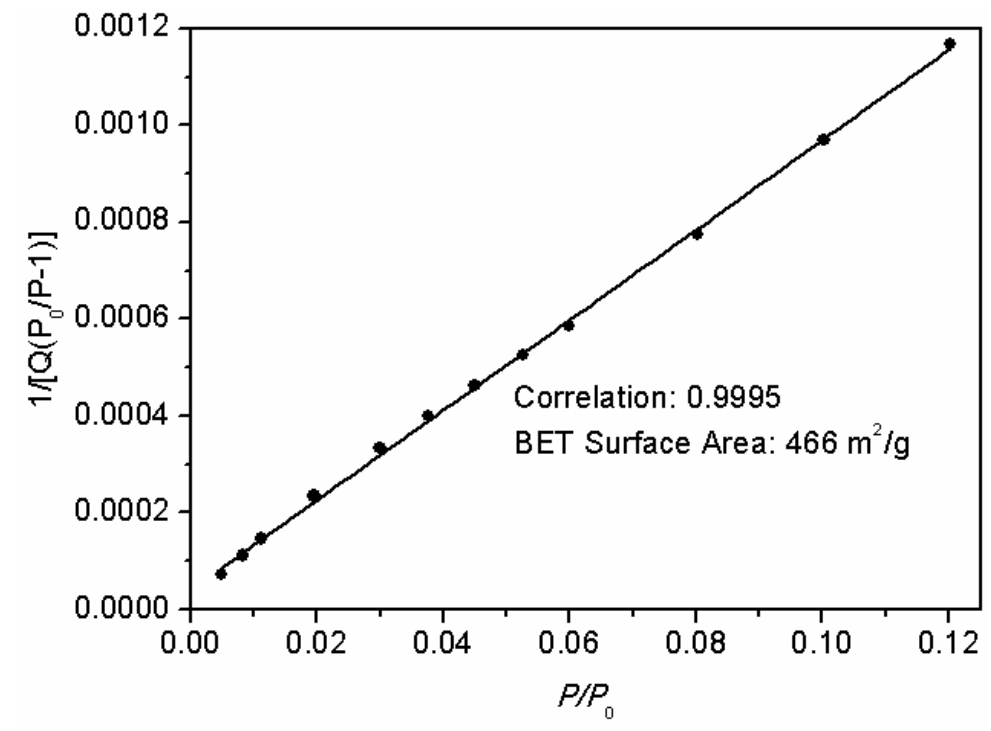

Figure S114. BET surface area plot for LZU-563 after treatment with $9 \mathrm{M} \mathrm{HCl}$ for 3 days. 


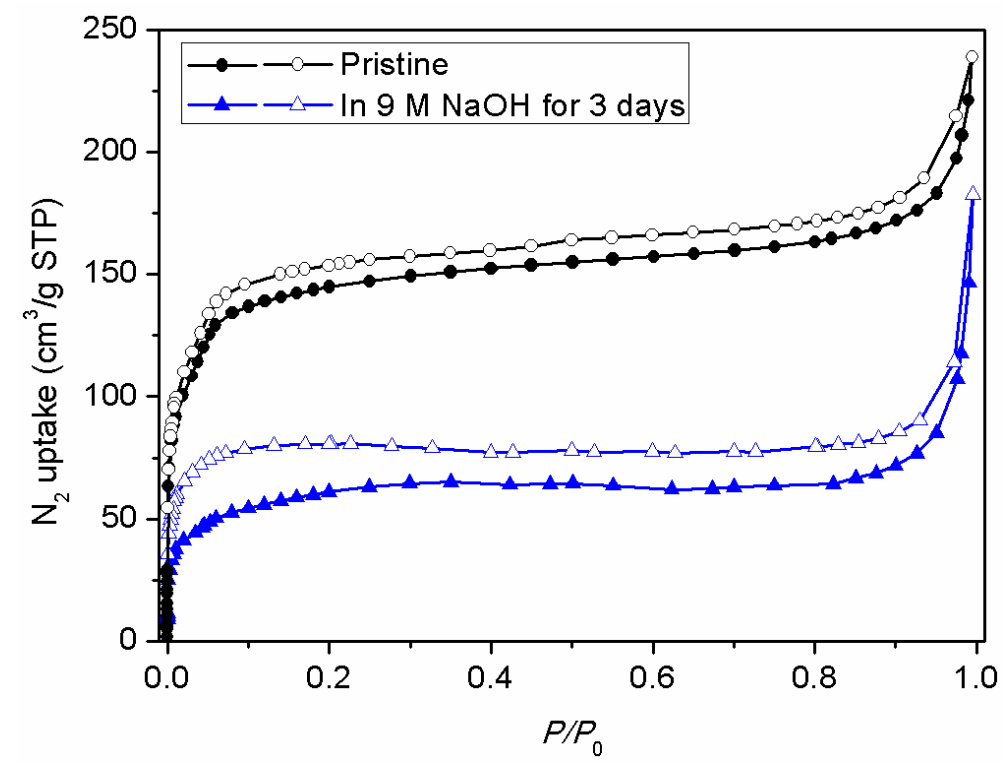

Figure S115. $\mathrm{N}_{2}$ adsorption (filled shapes) and desorption (open shapes) isotherms of LZU-563 before (black) and after treatment with $9 \mathrm{M} \mathrm{NaOH}$ for 3 days (blue).

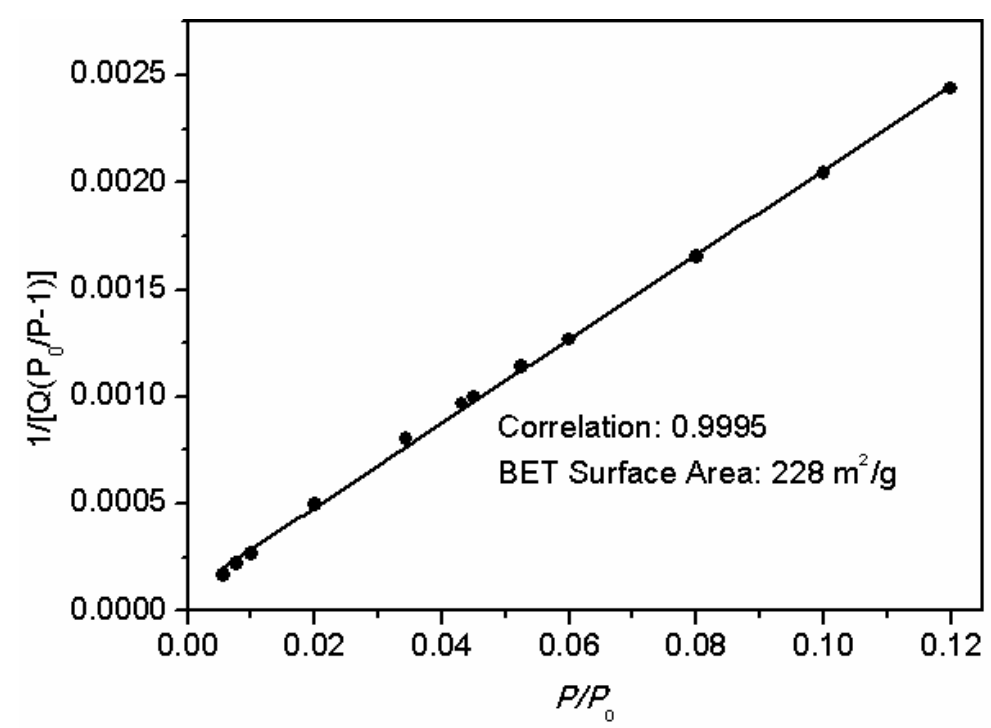

Figure S116. BET surface area plot for LZU-563 after treatment with $9 \mathrm{M} \mathrm{NaOH}$ for 3 days. 


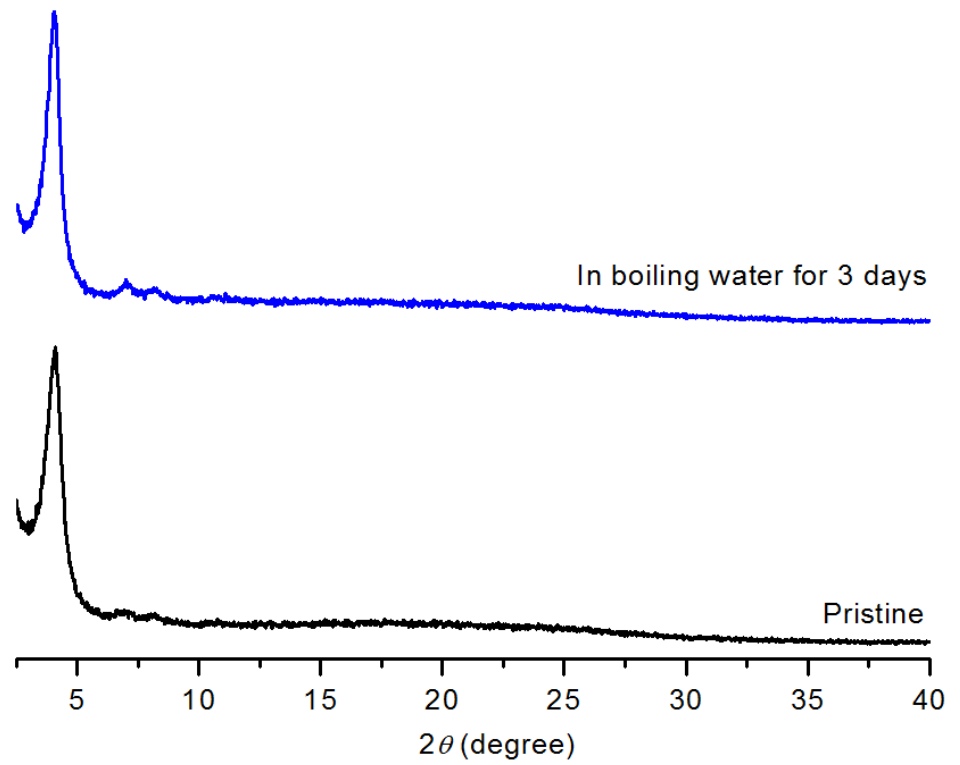

Figure S117. PXRD patterns of LZU-563 before (black) and after treatment with boiling water for 3 days (blue).

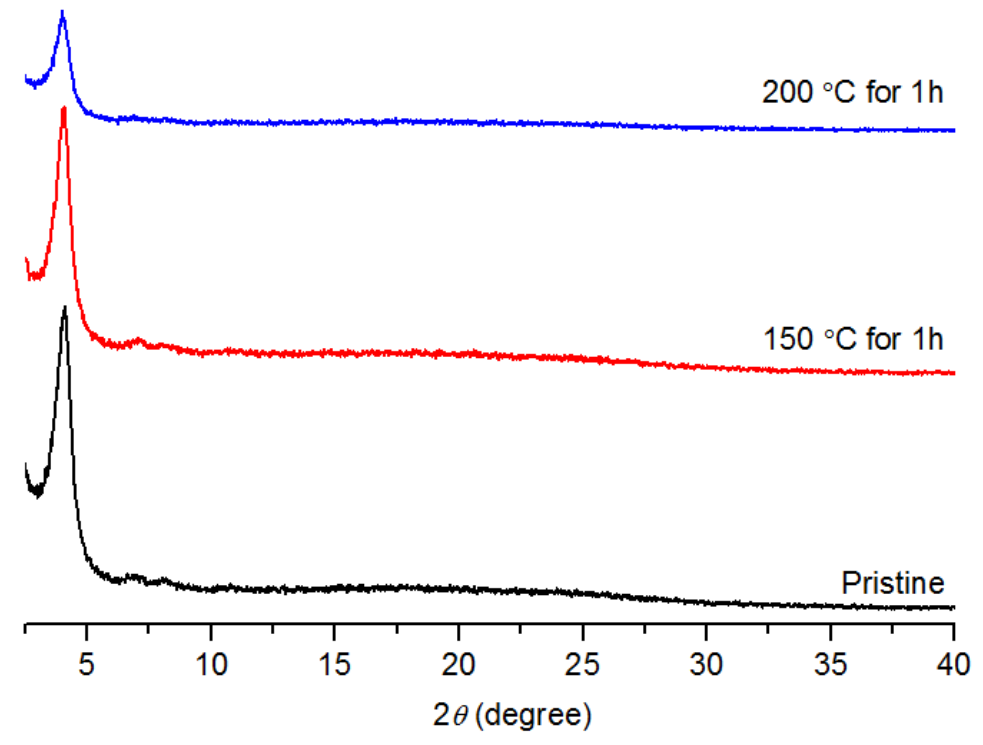

Figure S118. PXRD patterns of LZU-563 before (black) and after heating at $200{ }^{\circ} \mathrm{C}$ (blue) and $150{ }^{\circ} \mathrm{C}$ (red) for 1 hour. 
M. UV/Vis Absorption Spectra

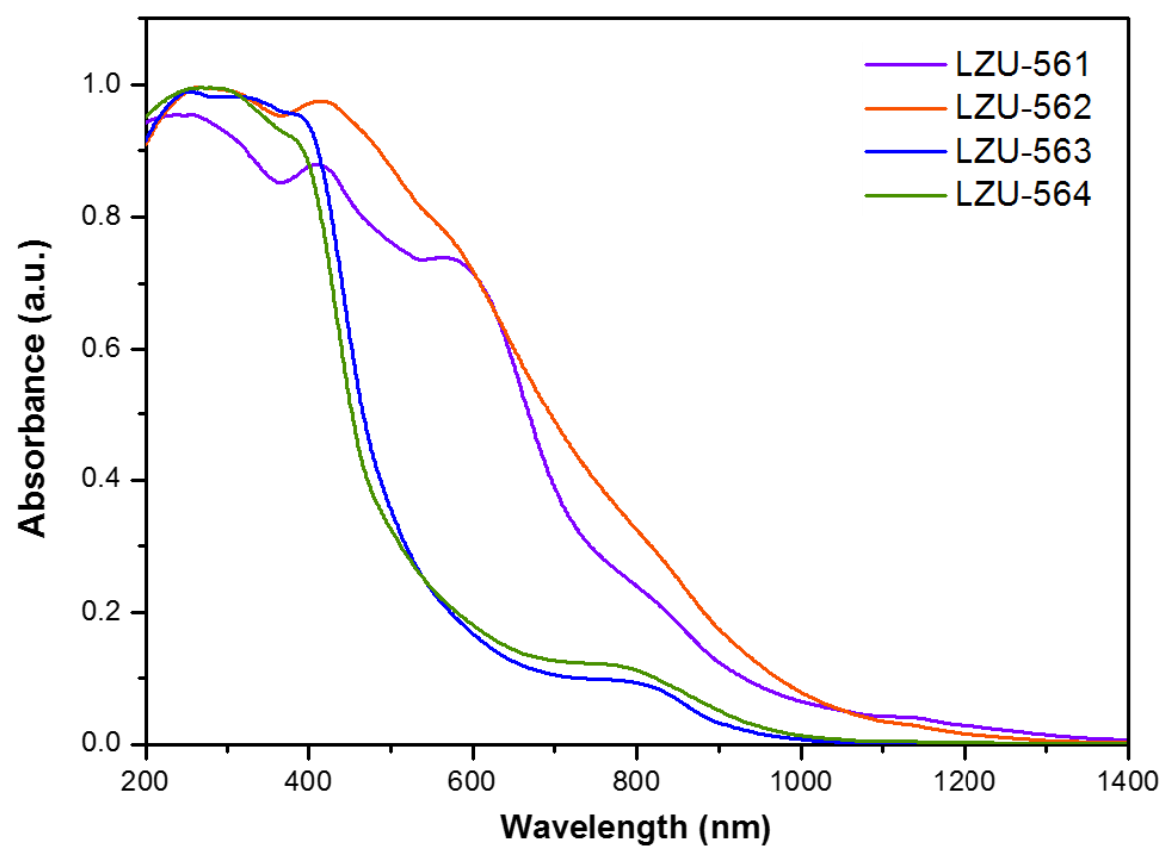

Figure S119. UV/vis absorption spectra of LZU-561, LZU-562, LZU-563, and LZU-564.

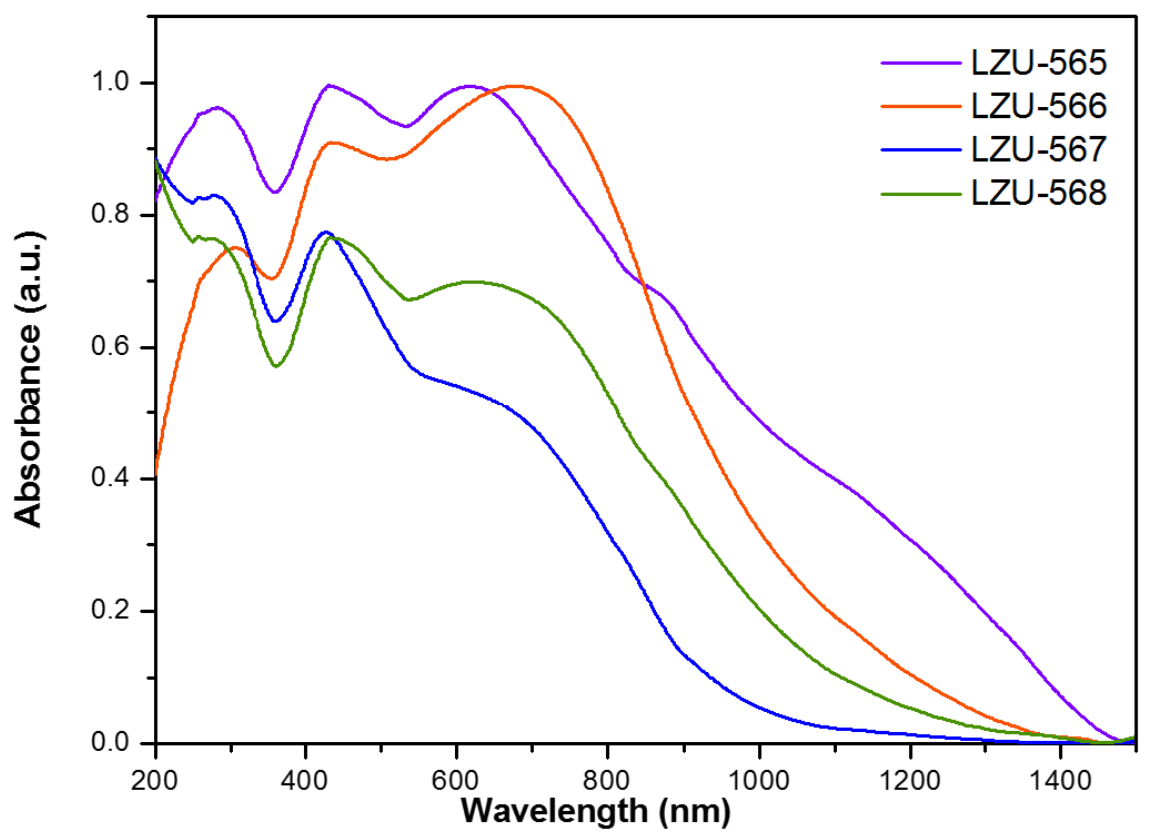

Figure S120. UV/vis absorption spectra of LZU-565, LZU-566, LZU-567, and LZU-568. 


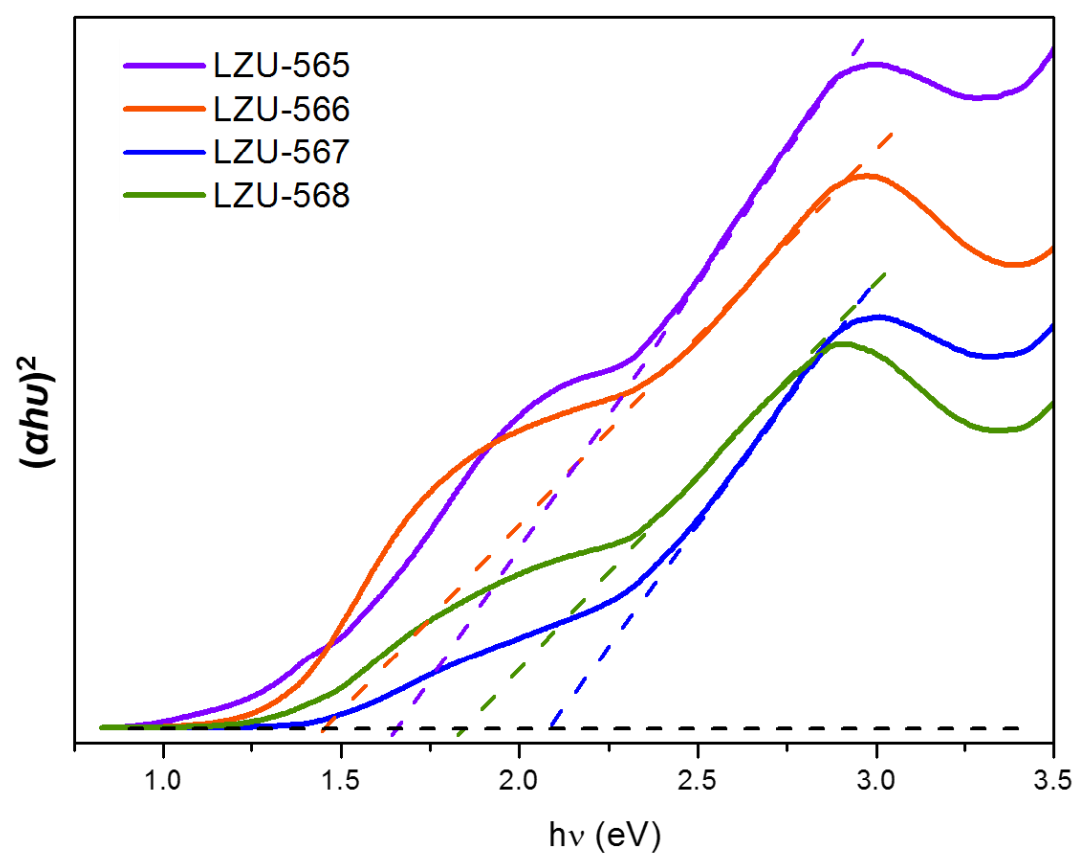

Figure S121. $(\alpha h v)^{2}$ versus hv curve of of LZU-565, LZU-566, LZU-567, and LZU-568. The horizontal dash line (black) marks the baseline; other dash lines are the tangents of the curves. The intersections indicate the values of estimated optical band gap. 


\section{N. References}

(1) Waldemar, G.; Anna N. G.; Synthesis and antiproliferative activity of aromatic and aliphatic bis[aminomethylidene(bisphosphonic)] acids. Bioorg. Med. Chem. Lett. 2014, 24, 3475.

(2) Shaabani, A.; Soleimani, E.; Maleki, A.; Moghimi-Rad, J. Self-assembled monolayers of dithiols, diisocyanides, and isocyanothiols on gold: 'chemically sticky' surfaces for covalent attachment of metal clusters and studies of interfacial electron transfer. Mol Divers. 2009, 13, 269.

(3) Materials Studio v.7.0 (Accelrys Software, San Diego, 2013). 


\section{O. Liquid ${ }^{1} \mathrm{H}$ and ${ }^{13} \mathrm{C}$ NMR Spectra}

$$
\text { | }
$$<smiles>O=[N+]([O-])c1ccc([N+](=O)[O-])cc1</smiles>
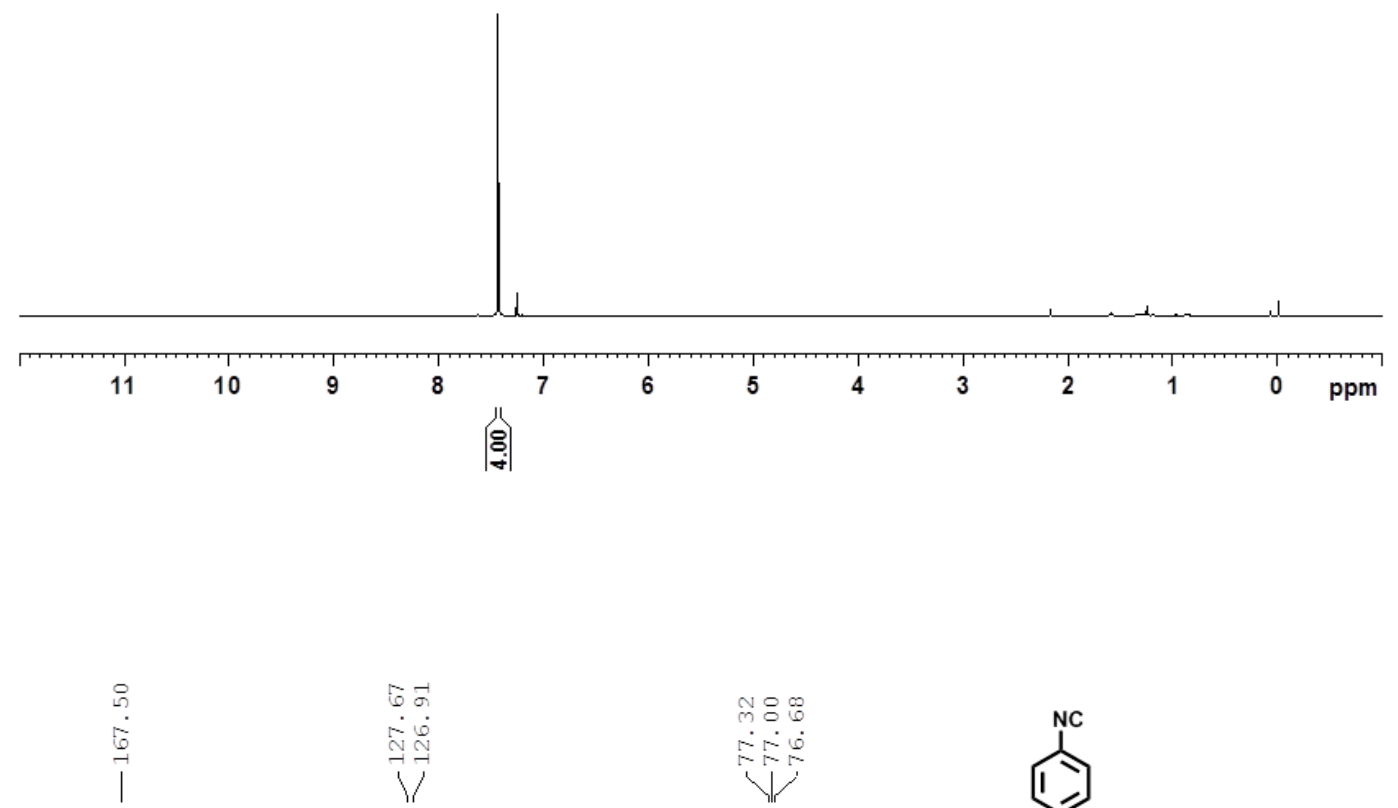

$$
\begin{array}{r}
1000 \\
0
\end{array}
$$<smiles>[N-]=[N+]([O-])c1ccc([N+](=O)[O-])cc1</smiles>

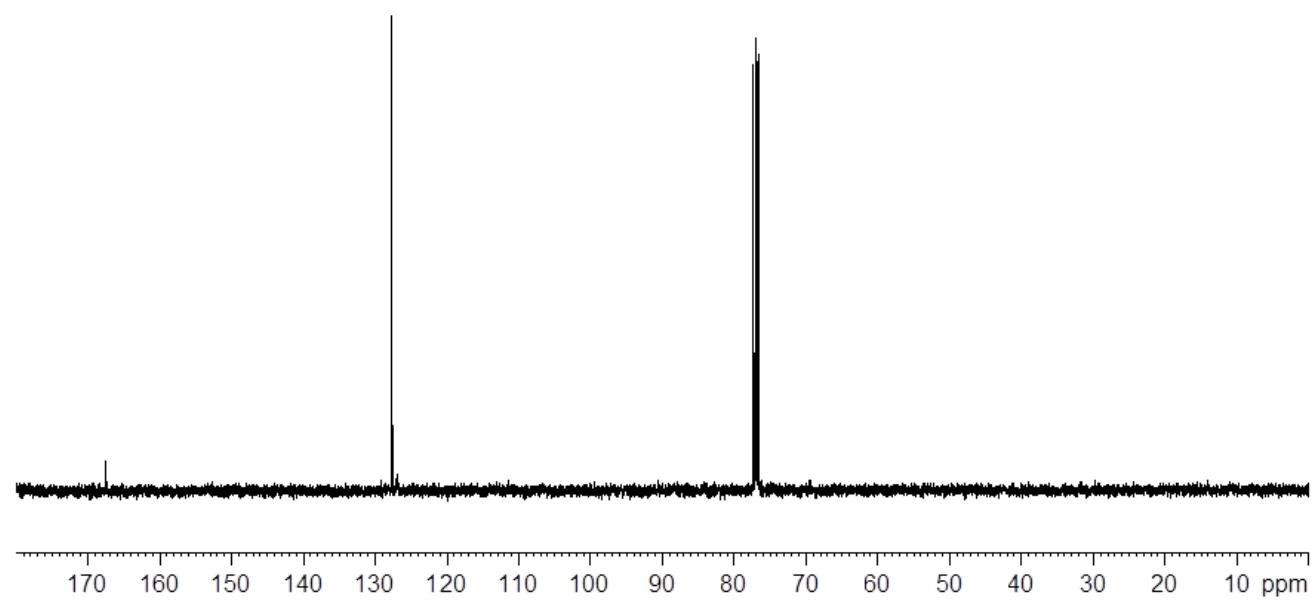




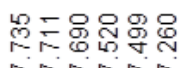

vis
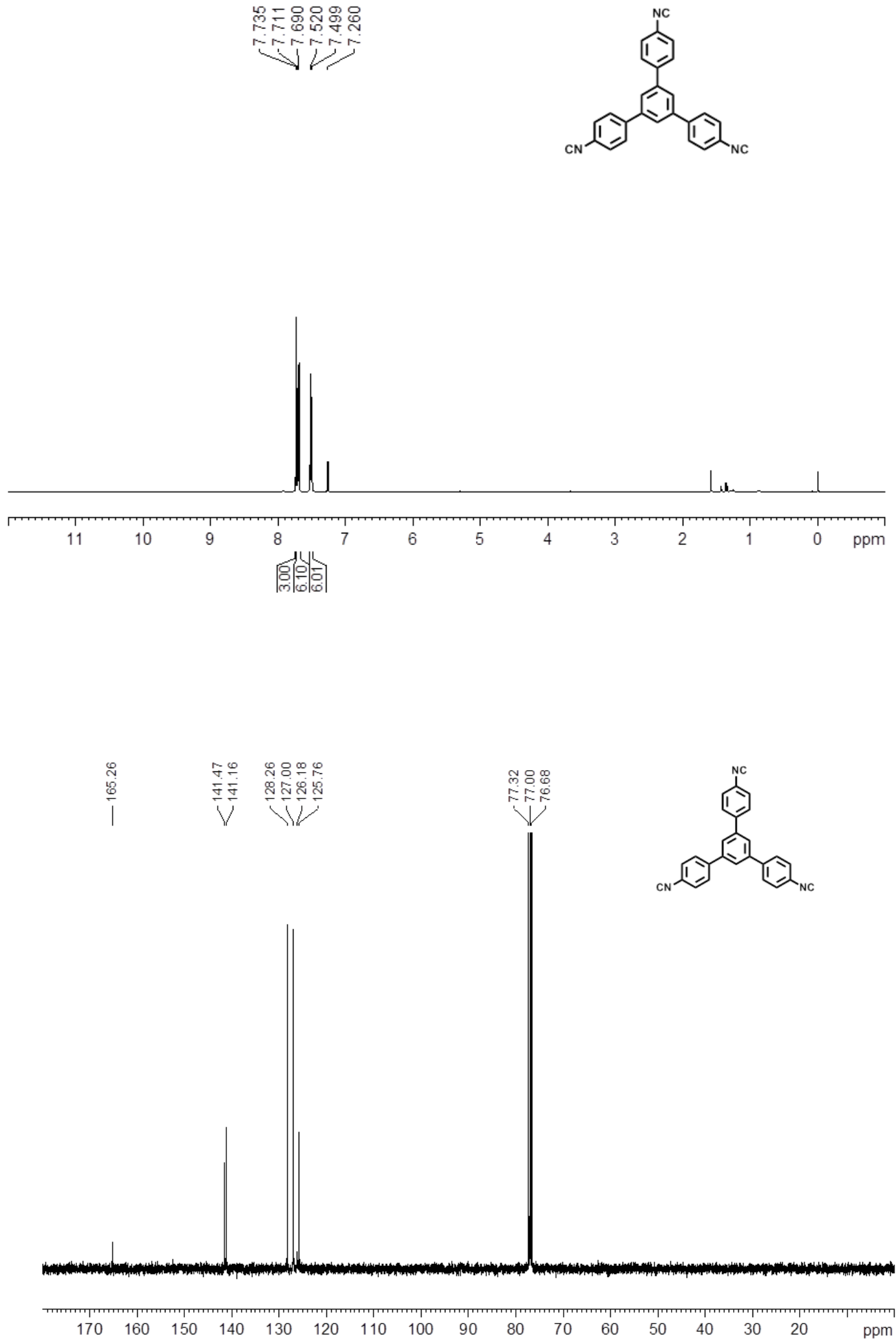

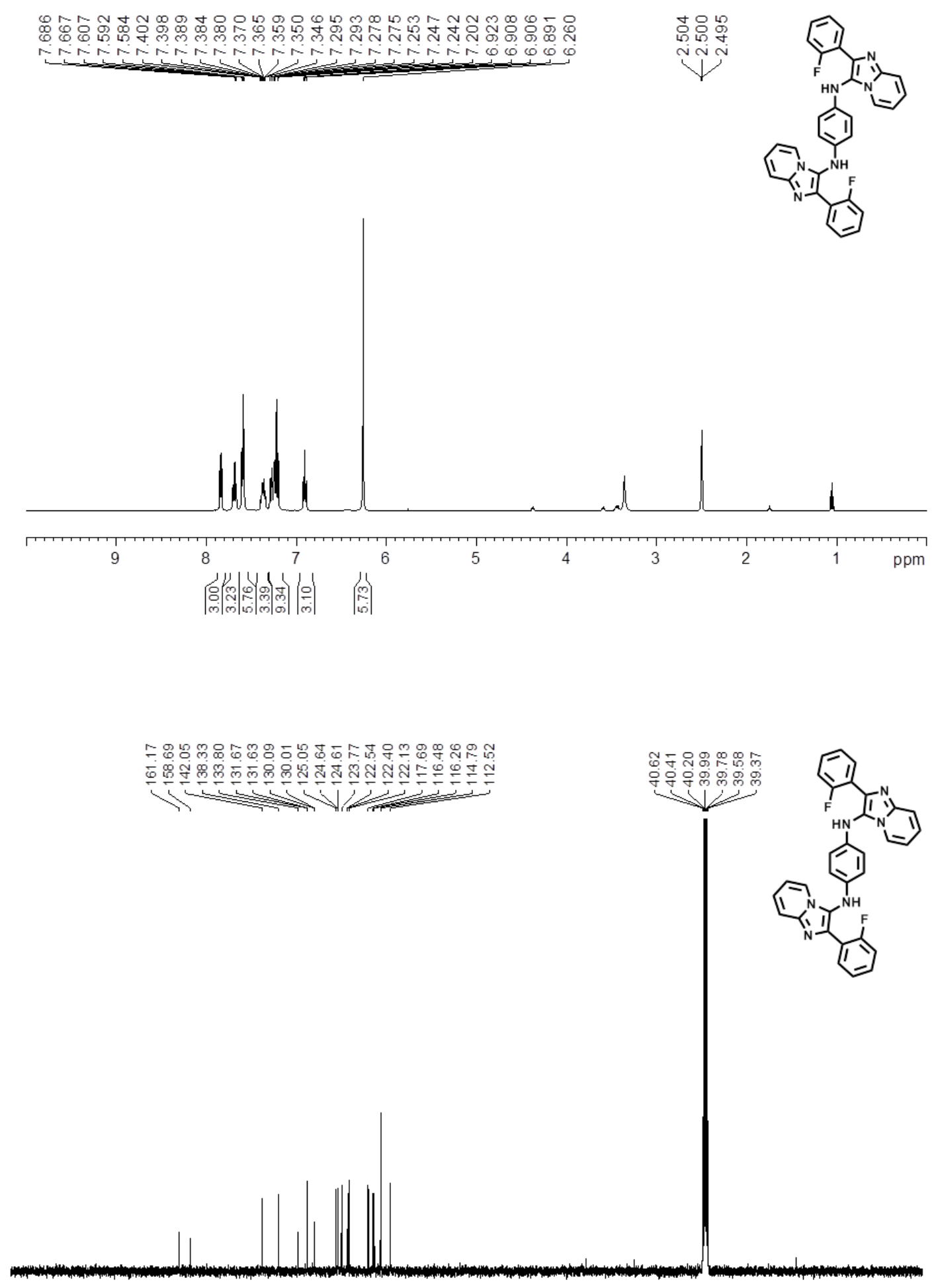

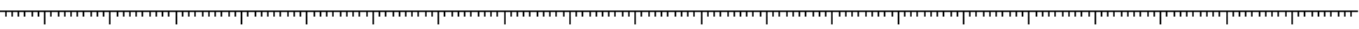

$\begin{array}{llllllllllllllllllll}190 & 180 & 170 & 160 & 150 & 140 & 130 & 120 & 110 & 100 & 90 & 80 & 70 & 60 & 50 & 40 & 30 & 20 & 10 & \mathrm{ppm}\end{array}$ 